\begin{tabular}{|c|c|c|}
\hline $\begin{array}{l}\text { 2. To: (Receiving Organization) } \\
\text { Distribution }\end{array}$ & $\begin{array}{l}\text { 3. From: (Originating Organization) } \\
\text { TWRS Projects/SST Retrieval }\end{array}$ & $\begin{array}{r}4 . \text { Related EDT No.: } \\
\mathrm{n} / \mathrm{a}\end{array}$ \\
\hline $\begin{array}{l}\text { 5. Proj./Prog./Dept./Div.: D 299/ } \\
\text { W-320 TWRS/TCPN \# }\end{array}$ & $\begin{array}{l}\text { 6. Design Authority/ Design Agent/Cog. } \\
\text { Engr:: } \\
\text { JW Bailey, NHC }\end{array}$ & $\begin{array}{l}\text { 7. Purchase Order No.: } \\
\qquad \mathrm{n} / \mathrm{a}\end{array}$ \\
\hline \multirow{2}{*}{\multicolumn{2}{|c|}{$\begin{array}{l}\text { 8. originator Renarks: } \\
\text { For approval and release of a new supporting document. This } \\
\text { document has been generated to ensure retrievability of the } \\
\text { Project W-320 "HVAC Calculations, Vol. l". }\end{array}$}} & $\begin{array}{l}\text { 9. Equip./Component Mo.: } \\
\mathrm{n} / \mathrm{a}\end{array}$ \\
\hline & & $\begin{array}{r}\text { 10. System/Bldg./Facility: } \\
241-C-106\end{array}$ \\
\hline \multirow{3}{*}{\multicolumn{2}{|c|}{ 11. Receiver Remarks: 11A. Design Baseline Document? [X] Yes [] No }} & $\begin{array}{l}\text { 12. Major Assm. Dwg. Ho.: } \\
n / a\end{array}$ \\
\hline & & $\begin{array}{l}\text { 13. Permit/Permit Appl ication No.: } \\
\text { n/a }\end{array}$ \\
\hline & & 14. Required Response Date: \\
\hline
\end{tabular}

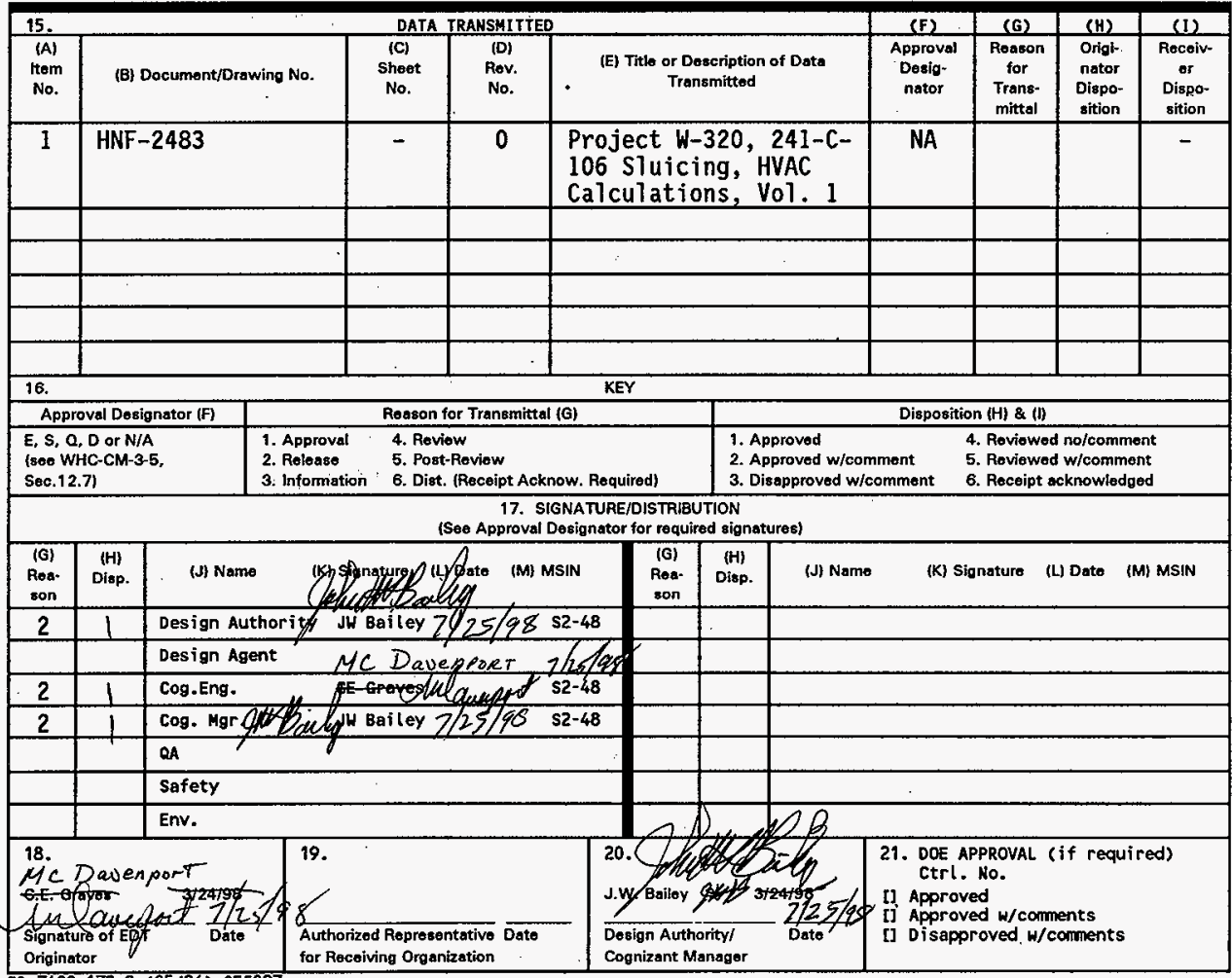


HNF-2483, Rev. 0

\section{Project W-320, 241-C-106 Sluicing HVAC Calculations, Vol. 1}

John W. Bailey

Numatec Hanford Co., Richland, WA 99352

U.S. Department of Energy Contract DE-AC09-96RL13200

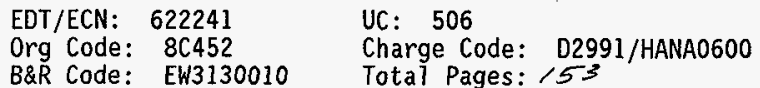

Key Words: W-320, Sluicing, Tank 241-C-106, Tank 241-AY-102, WRSS, calculations, HVAC.

Abstract: This supporting document has been prepared to make the FDNW calculations for Project $W-320$, readily retrievable.

TRADEMARK DISCLAIMER. Reference herein to any specific commercial product, process, or service by trade name, trademark, manufacturer, or otherwise, does not necessarily constitute or imply its endorsement, recommendation, or favoring by the United States Government or any agency thereof or $i$ ts contractors or subcontractors.

Printed in the United States of America. To obtain copies of this document, contact: Document Control Services, P.0. Box 950, Mailstop 166-08, Richland WA 99352, Phone (509) 372-2420;

Fax (509) 376-4989.
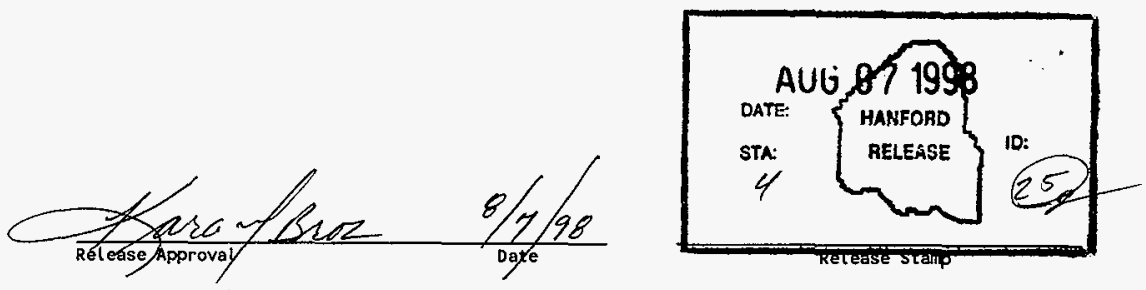

Approved for Public Release

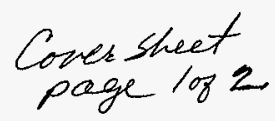


APPLICATION FOR PERMISSION TI
YOUR COPYRIGHTED MATAR

TO: NEW YORK BLOWER

Date: $07 / 29 / 98$

Permission is requested to reproduce the following copyrighted matesidifiom:

FAN CURVE FROM NEW YORK BLONER COMPANY BULLETIN. OATE: 3/19A1984:GISZE: 2606;

TAG: 20T: CFM: 360 .

$\because$

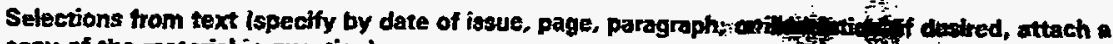

copy of the material in question):

FAN CURVE

Title of work or project in whlch this material will be ineluded:

W-320 PROJECT DOCUMENTATION

Eatimated publicution date: $07 / 31 / 98$

Author: Heo. Hellon

Publisher (if applicable): HANFORD SITE (RICHLAND. WASHINGTON) it is:

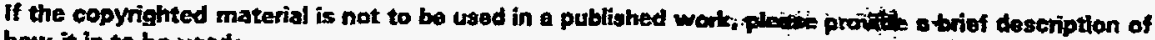
how it is to be used:

N/A

A self-addressed rampad envelope is enclosed fupoutpip:

Name: OWEN D. NELSON

Sigmature: for

$0 . D$. Yeloos

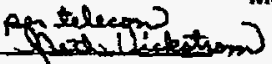

MSin: S2-48tin Dith

$07 / 29 / 98$

Credit line (if required):

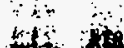

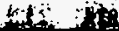

it

Application approved by:

Name:

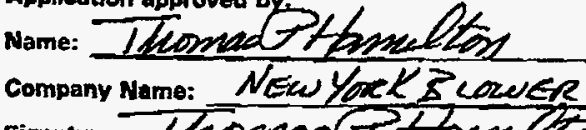

Signature:

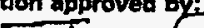

Date:

signatorite position: NoréLCESAVP

Ion bohringon ling 


\section{Project W-320, 241-C-106 Sluicing HVAC Calculations, Vol. 1}

TABLE OF CONTENTS

\begin{tabular}{|c|c|c|}
\hline Calc. No. & Title & Page \\
\hline$W 320-28-001$ & $\begin{array}{l}\text { Exhaust Airflow Sizing for Tank } \\
241-C-106\end{array}$ & $A-i$ \\
\hline W320-28-003 & $\begin{array}{l}\text { Equipment Sizing \& Selection } \\
\text { Recirculation Fan }\end{array}$ & $B-i$ \\
\hline W320-28-004 & Sizing High Efficiency Mist Eliminator & $c-i$ \\
\hline W320-28-005 & Sizing Electric Heating Coil & $D-\mathbf{i}$ \\
\hline W320-28-006 & $\begin{array}{l}\text { Equipment Sizing \& Selection } \\
\text { Recirculation Condenser }\end{array}$ & $E-\mathbf{i}$ \\
\hline W320-28-007 & $\begin{array}{l}\text { Chiller Skid System Sizing and } \\
\text { Selection }\end{array}$ & $F-\mathbf{i}$ \\
\hline W320-28-008 & $\begin{array}{l}\text { High Efficiency Metal Filter } \\
\text { Shielding Input and Flushing Frequency }\end{array}$ & G-i \\
\hline W320-28-011 & $\begin{array}{l}\text { Exhaust Skid Stack Sizing and Fan } \\
\text { Sizing }\end{array}$ & $H-i$ \\
\hline
\end{tabular}


HNF-2483, Rev. 0

W320-28-001

Exhaust Airflow Sizing for

Tank 241-C-106

$A-i$ 


\section{CALCULATION IDENTIFICATION AND INDEX}

This sheet shows the status and description of the attached Design Analysis sheets.
Discipline 28/HVAC
Wo/Job No. ER4319
Calculation No. W320-28-001

Project No. \& Name W-320 Tank 241-C-106 Waste Retrieval

Calculation Item Exhaust Airflow Sizing for Tank 241-C-106

These calculations apply to:

Dwg. No. H-2-818468 HVAC Overa11 Flow Diagram C-106

Owg. No. H-2-818479 HVAC Energy Balance

other (Study, CDR) N/A

Rev. No, draft 21, 3-17-95

Rev. No, draft 2, 3-21-94

Rev. No. N/A

The status of these calculations is:

[] Preliminary Calculations

[x] Final Calculations

[] Check Calculations (On Calculation Dated )

[] Void Calculation (Reason Voided)

Incorporated in Final Drawings?

[] Yes $[x]$ No

This calculation verified by independent "check" calculations? [] Yes $[x]$ No

Original and Revised Calculation Approvals:

\begin{tabular}{|c|c|c|c|}
\hline & $\begin{array}{c}\text { Rev. } 0 \\
\text { Signature/Date }\end{array}$ & $\begin{array}{c}\text { Rev. } 1 \\
\text { Signature/Date }\end{array}$ & $\begin{array}{l}\text { Rev. 2 } \\
\text { Signature/Date }\end{array}$ \\
\hline Originator & $\begin{array}{l}\text { superceeded by "/29/93 } \\
\text { revision 1.PH LANeowsk1 }\end{array}$ & Ift Lam $\ln 3.28 .95$ & \\
\hline Checked by & T.0. LoONEY $12 / 1 / 93$ & $2 \ln 3 / 31 / 95$ & \\
\hline Approved by & RW DAVIDSON $12 \mid 8 / 93$ & PHfacoude 4-345 & \\
\hline $\begin{array}{l}\text { Checked Against } \\
\text { Approved Vendor } \\
\text { Oata }\end{array}$ & & Chanen T. Li $4 / 10 / 98$ & \\
\hline $\begin{array}{c}\text { Design } \\
\text { Analysis } \\
\text { Page No. } \\
\end{array}$ & & $\frac{\text { INDEX }}{\text { Description }}$ & \\
\hline$i$ & Calculation Identification & and Index & \\
\hline 1 & Objective, Design Inputs & & \\
\hline $2-4$ & Calculations & & \\
\hline 5 & Findings \& Conclusions & & \\
\hline$\overline{A 1-A 10}$ & Appendix $\mathrm{A}$ & & \\
\hline $\mathrm{B} 1-\mathrm{B} 8$ & Appendix B & & \\
\hline
\end{tabular}

HNF-2483, Rev. 0

Page A-1 


\section{DESIGN ANALYSIS}

Client WHC

Subject $W-320$ Exhaust Airflow Sizing for Tank 241-C-106

Location 241-C Farm, 200 East
Calc. No. W320-28-001

Revision 1

Page No. 1 of 5

W0/Job No. ER4319

Date $3 / 28 / 95$

Checked $3 / 3 / 45$

Revised
By PH Langowski

By $\pi . P$ ins

By

\subsection{OBJECTIVE}

The objective of this calculation is to determine the range of exhaust airflow design values required for Tank 241-C-106 during active sluicing retrieval operations.

\subsection{DESIGN INPUTS}

\subsection{CRITERIA AND SOURCE}

DOE General Order 6430.1A

Functional Design Criteria WHC-SD-W320-FDC-001, rev. 2, 1-18-94

\subsection{GIVEN DATA}

- none

\subsection{ASSUMPTIONS}

Assumed C-106 tank minimum operating pressure of $-2.00 "$ water gauge (w.g.). This assumes that the operating pressure setpoint wi 11 be approximately -1.50 " w.g. With a range of control that would limit the minimum pressure to $-2.00^{\prime \prime} \mathrm{W} . \mathrm{g}$. under normal operating conditions. Operating pressure setpoint is stated as $-1.50^{\prime \prime}$ W.g. on ref. 6.

- Assumed the C-105 airspace temperature is equal to 80F and a vaporspace pressure of $-1.00^{\prime \prime}$ water gauge due to continuing radiolytic heat input. $C-105$ was formerly designated a high-heat watchlist tank and is estimated to have between 20,000 and 25,000 Btu/h of radiolytic heat generation in January, 1991 per Figure 12 of ref. 3 (see Appendix A). The thermal analysis shows that the temperature in $\mathrm{C}-105$ may reach $120 \mathrm{~F}$ if the ventilation is ceased. With a $\mathrm{C}-105$ ventilation rate of approximately $1,000 \mathrm{cfm}$ at a tank pressure of $-1.0^{\prime \prime}$ water gauge (similar to actual conditions on $2 / 5 / 91$ data), the tank average annual air temperature should be approximately $80 \mathrm{~F}$.

- Assumed a maximum infiltration rate of 250 scfm into tank C-106 through the three existing pits with cover blocks and the additional riser flanges. Actual infiltration will be less with the installation of the sealing tape from the $W$ 030 project and proper operating procedures. This assumes that the three cover blocks currently in place on $\mathrm{C}-106$ are replaced with new cover blocks which wi1] have covers for all penetrations ( ${ }^{\prime \prime}$ valve handle holes and others) through the cover blocks. The design of new. low-infiltration cover blocks is the current design assumption and design philosophy. Psychrometric data from DST's AW. AN. and AP (see Appendix A) shows that 250 scfm is a reasonable assumption for the maximum infiltration through the three existing cover blocks.

\subsection{METHODS}

Hand calculations and Excel spreadsheet using ASHRAE formulae. 


\section{DESIGN ANALYSIS}

Client WHC

Subject $W-320$ Exhaust Airflow Sizing for Tank $241-C-106$

Location 241-C Farm, 200 East
Calc. No. W320-28-001

Revision 1

Page No. 2 of 5

W0/Job No. ER4319

Date $3 / 28 / 95$

Checked $3 / 31 / 45$

By PH Langowski

Revised
By

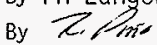

\subsection{REFERENCES}

1. WHC-SD-WM-ANAL-012, Rev. 1, "Flow Analysis for Single She 11 Tanks", p. 2

2. W320ER1.TD.395, "Tank 241-C-106 Sluicing Tank Farm Riser Usage and Pit Modifications," $9 / 93$.

3. WHC-SD-WM-ER-189, Rev. 0, "Thermal Analysis of Tank 241-C-105 in Support of Process Test," Figure 12, January 1993.

4. WHC-EP-0651, Rev. 0, "Barometric Pressure Variations, "June 1993.

5. W320-H-011, Rev. 0, "Exhaust Skid Stack Sizing and Fan Sizing"

6. H-2-818468, draft 21, 3-17-95, "Overal1 Flow Diagram C-106"

7. HW-72743, Rev. 19, "75'-0" Dia Storage Tanks Arrangements"

8. ASHRAE Fundamentals 1993

\subsection{CALCULATIONS}

The total airflow into Tank 241-C-106, and hence, the total exhaust flowrate from C-106 is estimated to be made of two components: 1) the infiltration through the three pit cover blocks and into the pit drains and infiltration through riser flanges outside of

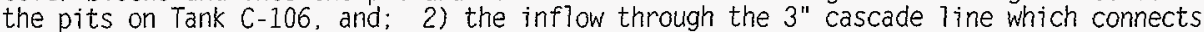
tank $\mathrm{C}-106$ to tank $\mathrm{C}-105$.

\subsection{Infiltration}

Riser Study ref. 2 (see Appendix A) detaj7s the current existing risers on Tank C-106. There are fourteen risers listed on the summary, seven of which are located inside the three pits. Of the remaining seven, one is covered with dirt and could be assumed sealed airtight. Of the remaining six, there are four $4^{\prime \prime}$ and two $12^{\prime \prime}$ risers. It is expected that a11 three existing pits on C-106 will have large openings into the tank and that the pit cover blocks will be the limiting infiltration path. No new risers are currently planned to be constructed under W-320. The existing 3 " floor drains in the three existing pits are not planned to be used after $W-320$ construction. The risers through which the pumps are inserted are planned to have perforated spacer rings which will provide a large drain opening to the tank. This large opening is thought to be required based on the accident scenario of $350 \mathrm{gpm}$ spilling into the pit.

A calculation of infiltration into the $\mathrm{C}-106$ tank with the equipment installed in the risers is severely dependent on the crack width assumptions used on each riser flange and on the pit cover blocks. This calculation was not undertaken due to it's inherent low reliability. The maximum 250 scfm infiltration rate for a $75^{\prime}$ diameter tank with three pits is based on psychrometric data from existing DST's (see Appendix A) which showed a wide range of airflows, generally in the 100 to $200 \mathrm{cfm}$ range, but with a few big exceptions. DST's generally have at least twice as many risers as SST's. The high end of the general range of the DST infiltration data was used.

The $W-320$ design assumes that the pit cover blocks are sealed so that the size of the drains in the pits is unimportant. This would yield infiltration rates near zero with only the purge air used for the FIC, purge air for the pressure transmitter PIT-1361 at Hatchway Riser R-15, the CCTV purge air, and the infiltration through the riser flanges on risers located outside of the pits or through penetrations in the pit cover blocks as contributors. This is a partially unrealistic assumption. Even if the pits are 


\section{DESIGN ANALYSIS}

Client WHC

Subject W-320 Exhaust Airflow Sizing for Tank $241-C-106$

Location 241-C Farm, 200 East
Calc. No. $\$ 320-28-001$

Revision 1

Page No. 3 of 5

wo/job No. ER4319

Date $3 / 28 / 95$

Checked $3 / 31 / 45$

By PH Langowski

By

By

sealed there will be times when the seals are broken for maintenance of items in the pits, or infiltration due to lack of maintenance of the seals themselves. The 250 scfm maximum infiltration assumption should prove conservative. For calculations where a normal operating flow rate is specified, 170 scfm shail be used.

The ref. 1 flow analysis report (see Appendix A) discusses infiltration rates into single shell tanks for various combinations of risers, pit drains, and pressures. For $2^{\prime \prime}$ W.g. pressure drop, the following infiltration rates were calculated: $23 \mathrm{cfm}$ for a tank with sealed pits: $425 \mathrm{cfm}$ for a tank with cover blocks off and pit drains sealed 50\%; $819 \mathrm{cfm}$ for a tank with cover blocks off and pit drains 100\% open; and. 2819 cfm for a tank with an open inlet filter and $100 \%$ open pit drains. pit drains are the standard 3" drains in the flow analysis report. The 250 scfm maximum infiltration assumption is reasonable in this context.

\subsection{Inflow Through Cascade Line}

The airflow through the $3^{\prime \prime}$ (ref. HW-72743 see Appendix B) cascade line of approximately $30^{\circ}$ length from $\mathrm{C}-105$ is calculated by assuming a delta pressure drop along the cascade line. Thirty feet of pipe with a $2^{\prime \prime}$ w.g. delta pressure drop would require a pressure drop of approximately $\left(2^{\prime \prime}\right)\left(100^{\circ} / 30^{\circ}\right)=6.67^{\prime \prime} \mathrm{W} . \mathrm{g}$. per $100^{\circ}$ of pipe and require $a$ substantial velocity. The entrance and exit losses should not be neglected at these high velocities.

The C-105 entrance is a 4" schedule 80 pipe on the 00 with the $3 "$ cascade line inside overhanging the sidewa71 of the tank by 12". The C-106 exit side is the $3^{\prime \prime}$ cascade Tine overhanging the tank by $4^{\prime}$ (see ref. 7). ASHRAE Fundamentals 1993 fitting ED1-1 was assumed to model the entrance in $\mathrm{C}-105$ (See Appendix B). Using Schedule 80 pipe data (see Appendix $B$ ), For $C-105: 2 t=4.5^{\prime \prime}-2.9^{\prime \prime}=1.6^{\prime \prime}$, so $t=0.8^{\prime \prime} ; L=12^{\prime \prime} ; \quad D=2.9^{\prime \prime}$; $t / D=0.8 / 2,9=0.276 ; L / D=12 / 2.9=4.14$; from the table $C_{0}=0.50$. The exit in $C-106$ can use $\mathrm{C}_{0}=1.00$ since the airstream decelerates to zero velocity.

Appendix $B$ contains a simple Excel spreadsheet which proved useful in iterating in on an airflow with a given delta pressure. ASHRAE Fundamentals (ref. 8) equations as listed on the spreadsheet were used to calculate friction factors and pressure loss through the piping. The entrance and exit losses which are dependent on velocity pressure are also included. The spreadsheet shows that a normally expected cascade airflow of $60 \mathrm{scfm}$ of $80 \mathrm{~F}$ air can be expected at $0.5^{\prime \prime} \mathrm{W} . \mathrm{g}$. total pressure drop between the two tanks. The same spreadsheet yielded $103 \mathrm{scfm}$ of $120 \mathrm{~F}$ air and 108 scfm of $80 \mathrm{~F}$ air at $1.5^{\prime \prime}$ W.g. total pressure drop simulating the case of C-105 not being ventilated. 110 scfm shal1 be used as the maximum cascade line airflow.

\subsection{Minimum Airflow}

DOE Order 6430.1A, para. 1550-99.0.3 "Offgas Systems", states that "the design of process confinement off-gas treatment systems shal1 preclude the accumulation of potentially flammable quantities of hydrogen generated by radiolysis or chemical reactions within process equipment." Review of SY-101 hydrogen generation was undertaken to investigate an assumed worst case. Scaling down an estimated 241-SY-101 steady-state hydrogen generation rate of $2.24 \mathrm{scfh}$ based on total mass yields a $\mathrm{C}-106$ steady-state hydrogen generation rate of $0.33 \mathrm{scfh}$. To operate safely below the lower 


\section{DESIGN ANALYSIS}

Client WHC

Subject W-320 Exhaust Airflow Sizing for Tank $241-C-106$

Location 241-C Farm, 200 East
Calc. No. W320-28-001

Revision 1

Page No. 4 of 5

w0/Job No. ER4319

Date $3 / 28 / 95$

checked $5 / 3 \% / 45$

Revised
By PH Langowsk $j$

By TPPin

By

explosive 7 imit only 1 scfm need be exhausted. The $W-030$ flammability calculations yielded a 3 scfm fresh air sweep requirement. The $W-320$ airstream characterization lists no flammable components.

Minimum airflow for infiltration should address the tank breathing rate due to changes in atmospheric pressure. Barometric Pressure Variation Report ref. 4 (see Appendix A) analyzes data for 1988-1991 as measured at the Hanford Weather Station located between $200 \mathrm{E}$ and $200 \mathrm{~W}$. The report presents the average breathing rate as 0.005639 inches of mercury per hour. It also presents hourly swing data. The largest value which occurred through the four year data collection is 0.12 inches of mercury per hour. The report presents annual average barometric pressures ranging from 29.22 to 29.26 inches mercury. The thirty year average for 1950 to 1980 is presented as 29.21 inches of mercury.

Assuming ideal conditions, the \% volume change in one hour would be:

$0.005639 / 29.21=0.0193 \%$ volume change per hour (average)

$0.12 / 29.21=0.41 \%$ volume change per hour (maximum)

A 530,000 gallon single shell tank consists of a $75^{\circ}$ diameter cylinder which is $18^{\circ}$ tall, a $12^{\prime}$ tall dome, and a $1^{\prime}$ deep dished bottom. The total tank volume would be:

cylinder: $(p j * 75 * 75 / 4)(18)=79,522$ cubic feet dish: approximately $(p ; * 75 * 75 / 4)(0.5)=2,209$ cubic feet dome: approximately pi*75*75*12/8 $=26,507$ cubic feet (paraboloid)

The total tank volume (neglecting any waste in the tank) is approximately:

$$
79,522+2,209+26,507=108,238 \text { cubic feet }
$$

At the average hourly volume change this yields:

$(0.000193$ volume/hour $)(108.238$ cubic feet $)(1$ hour $/ 60$ minutes $)=0.35 \mathrm{cfm}$

At the maximum hourly volume change this yields:

( 0.00411 volume/hour $)(108,238$ cubic feet $)(1$ hour $/ 60$ minutes $)=7.4 \mathrm{cfm}$

The maximum flowrate of $7.4 \mathrm{cfm}$ is the most that could be expected through infiltration due to pressure variations.

The minimum airflow requirement to properly operate the high pressure blower exhaust fan may prove to be a concern when detailed selection of fan and controls is undertaken. Calculation ref. 5. lists a potential fan for consideration. The fan should be able to operate down at any reduced airflows below the 180 scfm minimum sizing range since a radial high pressure blower can function down to shut-off routinely. 
Client WHC

\section{DESIGN ANALYSIS}

Subject $W-320$ Exhaust Airflow Sizing for Tank 241-C-106

Location 241-C Farm, 200 East
Calc. No. W320-28-001

Revision 1

Page No. 5 of 5

Wo/Job No. ER4319

Date $3 / 28 / 95$

Checked $3 / 3 / 1 / 5$

Revised
By PH Langowski

By Z P. Pisis

By

\subsection{FINDINGS \& CONCLUSIONS}

The total maximum exhaust airflow is the sum of the $250 \mathrm{scfm}$ infiltration airflow, and the $110 \mathrm{scfm}$ cascade line flow. This yields a total maximum exhaust design airflow of $360 \mathrm{scfm}$. $360 \mathrm{scfm}$ should be used for maximum exhaust design airflow purposes. Normal operating design airflow would be $60 \mathrm{scfm}$ cascade flow. plus $170 \mathrm{scfm}$ infiltration flow for a total of $230 \mathrm{scfm}$.

The proposed 360 scfm maximum exhaust air system can maintain the tank vapor space pressure at $-1.50 "$ water gauge under the worst case assumptions. 360 scfm should be used for maximum exhaust airflow sizing of equipment. The minimum absolute total exhaust airflow if Tank $\mathrm{C}-105$ were actively ventilated to an equal or more negative pressure than C-106 (or the cascade line is plugged) and infiltration is extremely small should be considered to be $70 \mathrm{scfm}$ infiltration (assumed). Neither of these two scenarios are deemed likely. For design purposes, the minimum exhaust airflow should be considered to be $60 \mathrm{scfm}$ cascade flow (0.5" w.g. Cascade line pressure drop) plus $120 \mathrm{scfm}$ infiltration for $180 \mathrm{scfm}$ tota?. 


\section{APPENDIX A}

HNF-2483, Rev. 0

Page A-7

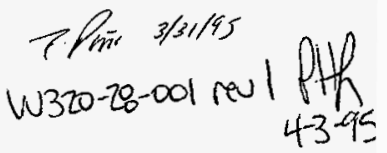


WHC-SD-WK-ER-189

ReV. 0

Figure 12. Calculated Temperatures to Year 2002. (Level $3-$ Level $4++$ )

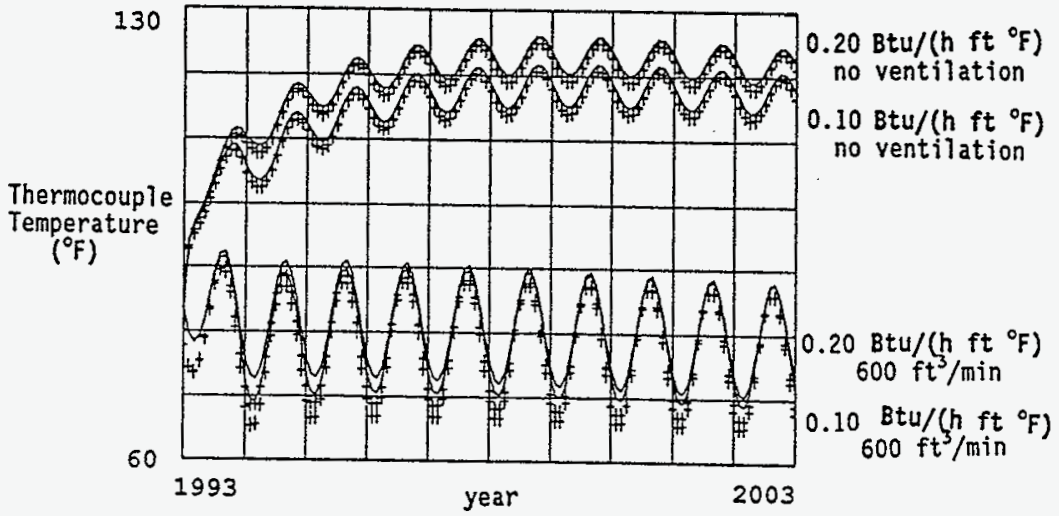

Table 1. Maximum Temperatures for Ory Out Transient.

\begin{tabular}{|c|c|c|c|c|}
\hline & \multicolumn{2}{|c|}{$\begin{array}{c}\text { Ventilation } \\
\left(600 \mathrm{ft}^{3} / \mathrm{min}\right)\end{array}$} & \multicolumn{2}{|c|}{ Ventilation off } \\
\hline $\begin{array}{c}\text { Minimum Waste Conductivity } \\
\left(\mathrm{Btu} /\left(\mathrm{h} \mathrm{ft}^{\circ} \mathrm{F}\right)\right)\end{array}$ & 0.2 & 0.1 & 0.2 & 0.1 \\
\hline $\begin{array}{c}\text { Maximum Waste Temperature } \\
\left({ }^{\circ} \mathrm{F}\right)\end{array}$ & 137 & 163 & 166 & 189 \\
\hline $\begin{array}{c}\text { Maximum Concrete Temperature } \\
\left({ }^{\circ} \mathrm{F}\right)\end{array}$ & 133 & 151 & 162 & 175 \\
\hline
\end{tabular}

HNF-2483, Rev. 0

Page A-8
R. Pmi $3 / 3 / 45$

W320-28-001 reul pitt

$4-3-95$ 
DATE: $\quad \epsilon-1.3 \cdot \delta G$

TO: Di.fitstin Dan taipe $R /-51$

Freir: Th: Tolingon

Zlüm bleq. Fin. $1: 3$

=00 ast isa-70)

$=-1857$

Fisycircietric Tanis Farm Eurvey 241-AP

Taken by: PUGGLES, LLARD KINZZL

The foilowing sirflow End temparature reccings rerg taken on

Date: $6-13-89$

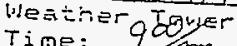

Time: 900 om Wet Eulb $63^{\circ} \quad$ :F ary Eulb

Pmbientigoo/ Wet Eulb $6<10$

\begin{tabular}{|c|c|c|c|c|c|c|c|c|}
\hline \multirow{2}{*}{$\begin{array}{l}\text { Ten: } \\
\text { No. }\end{array}$} & \multirow[t]{2}{*}{ Tine } & \multicolumn{2}{|c|}{ Tamosritur } & \multirow[b]{2}{*}{$\begin{array}{l}=10: 4 \\
\text { CFin }\end{array}$} & \multirow[b]{2}{*}{$\begin{array}{l}\text { Neg. Oft } \\
\text { Chart \% }\end{array}$} & \multirow{3}{*}{ 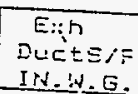 } & & \multirow[b]{2}{*}{$\begin{array}{l}\text { Neg.0i } \\
\text { Tenk: }\end{array}$} \\
\hline & & $\begin{array}{l}\text { NeX } \\
-F \\
\end{array}$ & $\begin{array}{l}\text { Ery } \\
\text { F }\end{array}$ & & & & $\begin{array}{l}\text { E:h Limp } \\
\text { ros. }\end{array}$ & \\
\hline$\frac{101}{102}$ & 190000 & 1680 & $162^{\circ}$ & 100 & $18 \%$ & & $\because$ OPEN & \\
\hline$\frac{102}{103}$ & $19750 \mathrm{~mm}$ & $\frac{168^{\circ}}{168^{\circ}}$ & 1680 & 1130 & $26 \%$ & $20.37 \div 6$ & 25 & $1-2.70$ \\
\hline 104 & $\mathrm{~B} 3 \mathrm{dm}$ & $170^{\circ}$ & $\frac{1}{123^{\circ}}$ & 1130 & $18 \%$ & $2.00-4.6$ & $2 \frac{5}{25}$ & $1-2.40 \times c$ \\
\hline 105 & $19.5 / \mathrm{sm}$ & $161^{\circ}$ & $170^{2}$ & 212 & $17 \%$ & $2.45-u=$ & $\frac{25}{20}$ & $1-2.80^{\prime}, 4$. \\
\hline 106 & $932 \mathrm{~m}$ & $160^{\circ}$ & $68^{\circ}$ & 1064 & 1079 & $291 \% 6$ & & $1-260^{\circ}<\mathrm{C}$ \\
\hline & & & & 188 & $15 \%$ & $2.55 \mathrm{seg}$ & 188 & $-300^{\circ} \cup 5$ \\
\hline & & 1 & & & & & & $1.2 .26 \geq 6$ \\
\hline$G M M$ & & & & & & & 1 & \\
\hline
\end{tabular}
$296 \cdot n \cdot 40$ $681 \mathrm{ckm}$

PBEfiEER

Pargoner

SEcondonty

$.80^{\circ}$ we die die

DEENTRAiris?

INLET TIMP les lue

ne

OuTue tene

\%

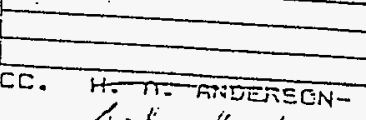

lioby thankin,

$\pi^{2}+\infty-1$

HNF-2483, Rev. 0

Page A-9

2. Pma 3/31/15

W320-28-001 rol tith 4- 
DATE: $7 / 17 / 89$

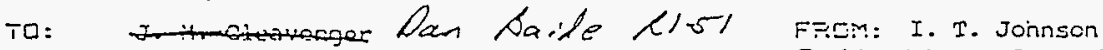

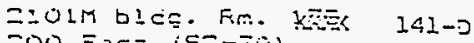
Z00 $\equiv$ 퐁 $\quad$ : $5=-70$ : $\beth-1 \subseteq \Xi 7$

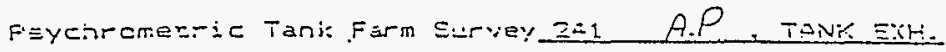

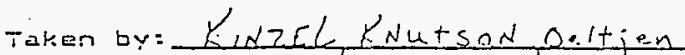

The foilcwing airficw and temparasure readings were taken on suíject tank.

Data: $=2 / 12 / 90$

Westher Tower: 00
Time:

Time: Wet SuIb :F Dry BuIb $7 \mathrm{C} \div$ Aิmoient:

Time: $10: 00$ We: EuLb -F Dry Euilo $75 \div$

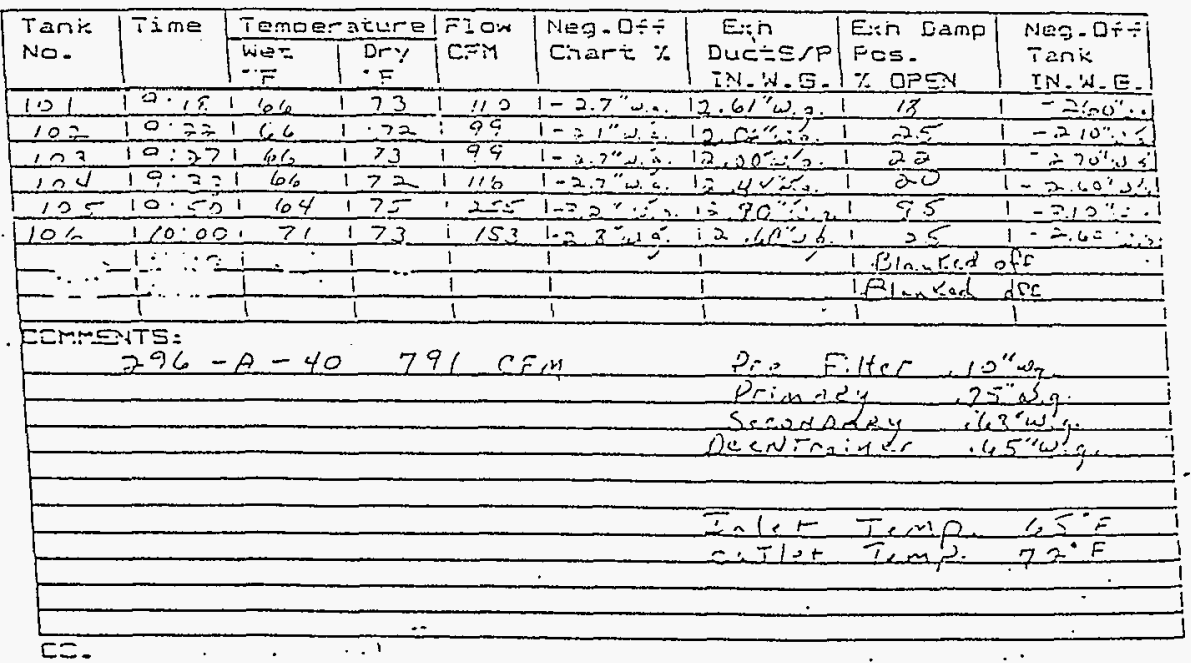

Det=y Hanlon $R /-J 0$ \%rims
HNF-2483, Rev. 0

Page A-10
T. Pind. $3 / 31 / 15$

$120-28-001$ re I fth $4-3-9$ 
$\therefore$ MaINTENANCE ERGINEERING SERVICES MAINTENANCE PROCEDURE AIRFLOW ND PSYCHROMDIIC RELINE ON UNDERGROUND WASTE

STORAGE TAMs Balance Data $241-g e$ Tank Farm 7-6i-05]

Rev. 2

Page 11 of 11

DATE: $2-8-90$

TO:

FROM: $2101-K R M$.

$200 E(52-70)$

Instrument Type micro

Instrument Last Calibration Date $1 /-x-89$

Instrument Code No. WHSL $202-38-09-0,3$

Psychometric Survey Tank 241, TANK EXH.

Taken By: Garrick, Tiffany e Malaise

The following airflow and temperature readings were taken on subject tank.

DATE: $2-5-90$

Weather Tower:

Time: gro Res Wet Bulb OF Dry Bulb

$\checkmark$

Ambient:

Time:

$N / A$

Wet Built ${ }^{\circ}$ F Dry Bulb of

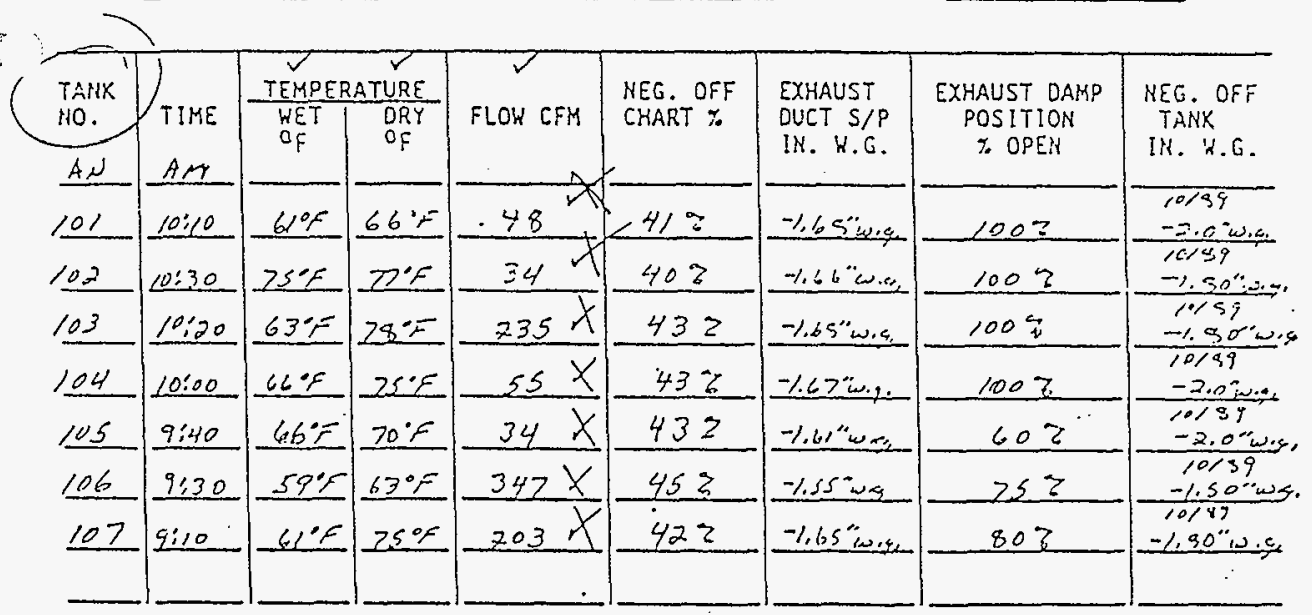

COMMENTS: No Ambient readings due t. broxtew equipment.

Ira Johnson, Manager Ventilation Balance

TEST RECORD SHEET 3.

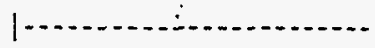

HNF-2483, Rev. 0

Page A-11

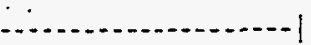

$20-28-001$ real pl 4-3-9. 
$\therefore \quad-\cdots$ MARI ENAMEL EMUMLL...... -........

AIRFLOW AND PSYCHRCHE

C READING ON UNDERGROUND WASTE

VTorsat \& Bays

$241-\ldots w$ Tank Fard

DATE: $2-5-90$

TO:

Instrument Type micro

Instrument Last Calibration Date 1/-8-99

Instrument Code No. HHSL $202.28-09-0,3$

Psychometric Survey Tank 241, TAlk K EXH.

Taken By: Carries, McRuse+Tiffaw,
Rev. 2

Page 11 of 11

$$
\text { FROM: } \begin{aligned}
& 2101-M \text { RH. } \\
& 200 \mathrm{E}(52-70) \\
& 3-1857
\end{aligned}
$$

The following airflow and temperature readings were taken on subject tank.

DATE: $2-9-90$

Weather Tower:

Time: Li, LS

Wet Bulb

35 of Dry 3476 ${ }^{\circ} \mathrm{F}$

Ambient:

Time:

$\nu / A$

Wet Bulb OF Dry Bulb ${ }^{\circ} \mathrm{F}$

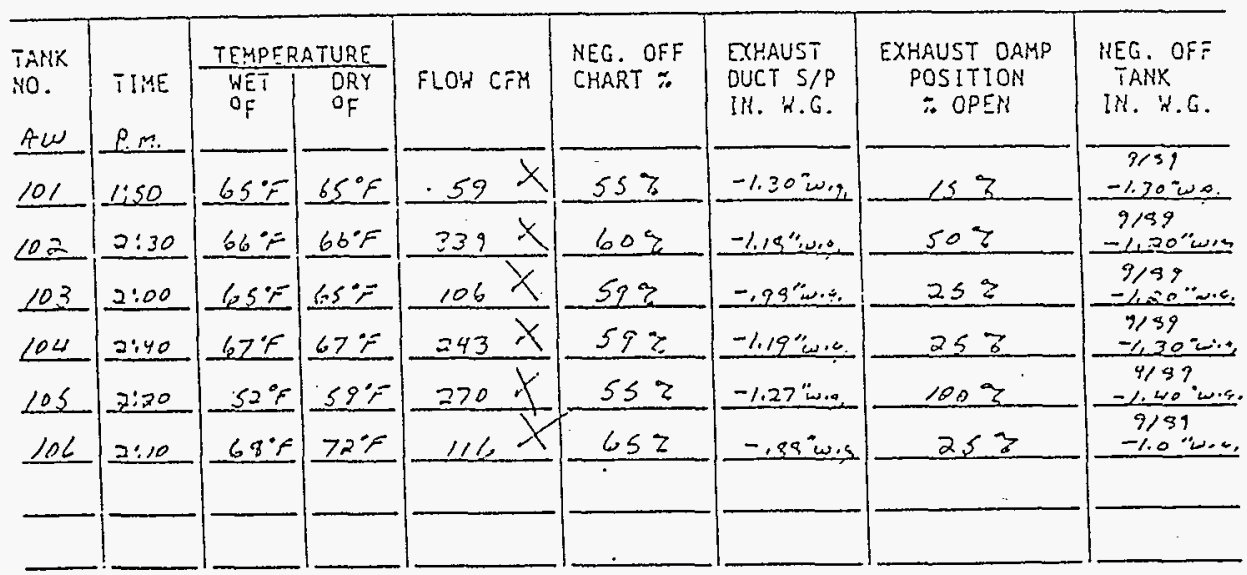

COMMENTS: Ambient inst braked $x t-s-2$ fou inservice

Ir z Johnson, Manager Ventilation Balance

IFS RECORD SHEET?

HNF-2483, Rev. 0

Page A-12
T. $\operatorname{Prn} 3 / 31 / 95$

78-00 pul Pith 4-3.95 


\begin{tabular}{|c|c|c|}
\hline Riser & Existing Use & Proposed Modification \\
\hline \multicolumn{3}{|c|}{ TANK $241 \mathrm{C}-106$} \\
\hline $\mathrm{Ri}-4$ in. & FIC & \\
\hline $\mathrm{R} 2-12$ in. & HVAC Outlet & HVAC Outlet \\
\hline $\begin{array}{c}-42 \text { in. } \\
(36 \text { in.) }\end{array}$ & $\begin{array}{l}\text { Dirt Covered Construction } \\
\text { Manhole }\end{array}$ & . \\
\hline \multicolumn{3}{|c|}{ TANK $247 \mathrm{C}-106$ SLUICE PIT } \\
\hline $\mathrm{R} 3 \cdot 12 \mathrm{in.}$ & $\begin{array}{l}\text { Liquid Level Tape } \\
\text { Riser blanked, H-2-73346 }\end{array}$ & $\begin{array}{l}\text { Install New Sluicer } \\
\text { Risers.empty and open }\end{array}$ \\
\hline R4 - 4 in. & $\begin{array}{l}\text { Recirc Dipleg } \\
\text { Still there, H-2-73346 } \\
\text { Sluice Pit Drain }\end{array}$ & $\begin{array}{l}\text { Dipleg is laying in pit } \\
\text { Riser is empty and open }\end{array}$ \\
\hline \multicolumn{3}{|c|}{ TANK 241 C $106 \mathrm{HEEL}$ RIT } \\
\hline$R 13-26$ in. & $\begin{array}{l}\text { Heel Jet Pump } \\
\text { Still there, } \mathrm{H}-2-73346 \\
\text { Heel Pit Drain }\end{array}$ & $\begin{array}{l}\text { Install New Heel Pump } \\
\text { Possibly Modify Riser dia. } \\
\text { Remove Old Pump }\end{array}$ \\
\hline \multicolumn{3}{|c|}{ TANK 24100106 PUMP PIT } \\
\hline R5 - 4 in. & $\begin{array}{l}\text { Recirc Dipleg } \\
\text { Still there, } \mathrm{H}-2-73346 \\
\text { Pump Pit Drain }\end{array}$ & Riser is empty and open \\
\hline R6 - 12 in. & Sluicing Access & New Sluicer \\
\hline$R 7-12$ in. & $\begin{array}{l}\text { Observation Port } \\
\text { In wall of Pit } \\
\text { See H-2-93726. } \\
\text { Blind Flange on Riser }\end{array}$ & Visual System Installation \\
\hline $\begin{array}{l}8-9-42 \text { in. } \\
(36 \text { in. })\end{array}$ & $\begin{array}{l}\text { Sludge Pump } \\
\text { Still there, } \mathrm{H}-2-73346\end{array}$ & New Submersible Pump \\
\hline \multicolumn{3}{|c|}{ TANK $241<106 / 8$. } \\
\hline R8 - 4 in. & $\begin{array}{l}\text { Temp Cont. } \\
\text { Still there, } \mathrm{H}-2-73346 \\
\text { West of Pump Pit }\end{array}$ & . \\
\hline R11- 4 in. & $\begin{array}{l}\text { Southeast of Heel Pit (below } \\
\text { grade) }\end{array}$ & \\
\hline R14 - 4 in. & Thermocouple Tree & \\
\hline \multicolumn{3}{|c|}{ TANK 241-C-106 HVAC INTAKE } \\
\hline RIS- 12 in. & $\begin{array}{l}\text { HVAC, HEPA Filtered Intake } \\
\text { Intake, Riser plate could be } \\
\text { made larger }\end{array}$ & HVAC Intake \\
\hline
\end{tabular}

HNF-2483, Rev. 0

Page A-13

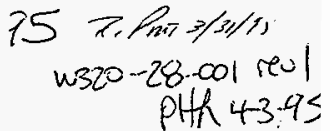




\subsection{INTRODUCTION}

The purpose of this document is to show the analytical results which were reached in determining the minimal flow rate for one air change per day from a single shell tank. "Also, what flow rate will be required to maintain a static pressure of $-.3^{\prime \prime} \mathrm{Wg}$ to $-5.9^{*} \mathrm{wg}$ in the tank (DOE Order 6430.1A page 11-4 paragraph 1161-4, and OSD \#113). This flow may be used to size a exhauster for both, before and after stabilization. Please review all the assumptions made during this analys is very carefully. These assumptions are uncontrolled variables (ie.. drains being plugged by dirt and debris), therefore, close attention should be paid to these assumptions.

\subsection{SCOPE}

The flow rates and static pressures were determined by the following four scenarios:

- 2 - 4" risers and 2 - 6" risers with a crack width of $1 / 64^{\prime \prime}$ each, 3 - $3^{\prime \prime}$ drains in the sluice pits (completely open free from debris), and $1-4^{\prime \prime}$ drain in the pump pit (completely open free from debris). In addition, $50 \mathrm{cfh}$ or $.833 \mathrm{cfm}^{2}$ is al so added due to purge air used by the FIC.

- $2-4^{\prime \prime}$ risers and $2-6^{n}$ risers with a crack width of $1 / 64^{*}$ each, 3 - $3^{\prime \prime}$ drains in the sluice pits $150 \%$ of the drain blocked due to dirt and debris), and $1-4 "$ drain in the pump pit (50\% of the drain blocked due to dirt and debris). In addition, $50 \mathrm{cfh}$ or $.833 \mathrm{cfm}^{2}$ is also added due to purge air used by the FIC.

o 1 - inlet filter placed on a 12" riser with flow through both, the inlet filter, and flow going through the above mentioned cracks. In addition, $50 \mathrm{cfh}$ or $.833 \mathrm{cfm}^{2}$ is also added due to purge air used by the FIC.

- 2 - 4" risers and $2-6^{\text {" }}$ risers with a crack width of $1 / 64^{\prime \prime}$ each, and the sluice pits and pump pit are sealed up completely (no inleakage through pits). In addition, $50 \mathrm{cfh}$ or $.833 \mathrm{cfm}^{2}$ is also added due to purge air used by the FIC.

The tank which was used for this anaiysis was 104-AX. This tank had the largest vapor space (gal.) due to the lowest liquid level (gal.) of all single sheil tanks. This was determined by using the March 30, 1991 Tank Farm Facilities Chart (see appendix $B$ ).

$1=$ Internal Keno from J.D. Thonson and J.L. Deichman to K.A. Payne, 2-18-92, single Shell Tank Ventillation Systens

2 : Information supplied by A.T. Alstad and V.D. KaLpin

HNF-2483, Rev. 0

Page A-14

"ints $3 / 21 / 75$

$20-28-00$ reu ( fHe $4-3$ 
WHC-SD-WM-ANAL-012

REVISION $g / \mathrm{R}_{Q}^{\mathrm{d}}+\mathrm{g}^{2}$

\subsection{RESULTS}

All scenarios, which were mentioned above, were evaluated, labeled, and explained in Appendix $A$. The results were as follows:

\begin{tabular}{|c|c|c|c|c|}
\hline$\frac{\text { PRESSURE DROP }}{\text { in. } \mathrm{Wg}}$ & $\frac{\text { SCENARIO } \# 1^{3}}{\mathrm{cfm}}$ & $\frac{\text { SCENARIO } 2^{3}}{\mathrm{Cfm}}$ & $\frac{\text { SCENARIO } \# 3^{1,2,3}}{\mathrm{cfm}}$ & $\frac{\text { SCENARIO }}{\mathrm{cfm}}$ \\
\hline $.3^{n} \mathrm{WG}$ & 317 & 165 & $300+\# 1$ or $\# 2$ & 9 \\
\hline $1^{*} \mathrm{wg}$ & 579 & 301 & $1000+\# 1$ or $\# 2$ & 16 \\
\hline 2" wg & 819 & 425 & $2000+\# 1$ or $\# 2$ & 23 \\
\hline 3" $\mathrm{wg}$ & 1003 & 521 & $3000+\# 1$ or $\# 2$ & 28 \\
\hline 4"wg & 1158 & 601 & $4000+\# 1$ or $\# 2$ & 33 \\
\hline 5" wg & 1333 & 672 & $5000+\# 1$ or $\# 2$ & 37 \\
\hline $5.9^{\prime \prime} \mathrm{wg}$ & 1406 & 730 & $5900+\# 1$ or $\# 2$ & 40 \\
\hline
\end{tabular}

$1=$ Based on damper being completely open

$2=$ See page 16 in Appendix A for reasoning of additive flows

$3=.83 \mathrm{cfm}$ needs to be adjed to these values for the purge air off the FIC 
Table 4. Population of Pressure Changes Every Hour.

\begin{tabular}{|c|c|c|c|c|}
\hline \multirow{2}{*}{$\begin{array}{l}\text { Press swing } \\
\text { (inches of mercury) }\end{array}$} & \multicolumn{4}{|c|}{ Year } \\
\hline & 1988 & 1989 & 1990 & 1991 \\
\hline-0.13 or lower & 0 & 0 & 0 & 0 \\
\hline-0.12 & 0 & 0 & 1 & 0 \\
\hline-0.11 & 3 & 1 & 1 & 3 \\
\hline-0.10 & 0 & 2 & 1 & 0 \\
\hline-0.09 & 2 & 0 & 1 & 0 \\
\hline-0.08 & 3 & 3 & 3 & 3 \\
\hline-0.07 & 1 & 2 & 4 & 4 \\
\hline-0.06 & 10 & 5 & 15 & 7 \\
\hline-0.05 & 26 & 10 & 27 & 16 \\
\hline-0.04 & 130 & 86 & 128 & 110 \\
\hline-0.03 & 344 & 238 & 294 & 302 \\
\hline-0.02 & 890 & 915 & 990 & 976 \\
\hline-0.01 & 1,446 & 1,583 & 1,435 & 1,473 \\
\hline 0 & 2,838 & 2,934 & 2,785 & 2,825 \\
\hline 0.01 & 1,772 & 1,806 & 1,674 & 1,703 \\
\hline 0.02 & 930 & 888 & 995 & 958 \\
\hline 0.03 & 266 & 181 & 252 & 231 \\
\hline 0.04 & 76 & 71 & 99 & 89 \\
\hline 0.05 & 17 & 14 & 31 & 33 \\
\hline 0.06 & 13 & 8 & 14 & 13 \\
\hline 0.07 & 3 & 2 & 0 & 7 \\
\hline 0.08 & 1 & 0 & 4 & 2 \\
\hline 0.09 & 3 & 2 & 1 & 0 \\
\hline 0.10 & 1 & 0 & 2 & 1 \\
\hline 0.11 & 1 & 3 & 0 & 1 \\
\hline 0.12 & 2 & 1 & 1 & 0 \\
\hline 0.13 or higher & 0 & 0 & $1^{*}$ & 0 \\
\hline
\end{tabular}

"One reading was 0.18 but is ascribed to an error, see discussion in Section 1.2, "Raw Data."

HNF-2483, Rev. 0

Page A-16
Plon $3 / 31 / 95$

$20-28.001$ reul pith 
Table 1. Annual Data.

\begin{tabular}{|l|c|c|c|c|c|}
\hline \multirow{2}{*}{ Value } & \multicolumn{5}{|c|}{ Year } \\
\cline { 2 - 6 } & 1988 & 1989 & 1990 & 1991 & $1950-1980^{*}$ \\
\hline $\begin{array}{l}\text { Average } \\
\text { (inches of mercury) }\end{array}$ & 29.25 & 29.26 & 29.22 & 29.23 & 29.21 \\
\hline $\begin{array}{l}\text { Standard deviation } \\
\text { (inches of mercury) }\end{array}$ & 0.211 & 0.197 & 0.193 & 0.210 & - \\
\hline Number & 8779 & 8756 & 8760 & 8758 & - \\
\hline $\begin{array}{l}\text { Maximum } \\
\text { (inches of mercury) }\end{array}$ & 29.94 & 29.96 & 30.02 & 29.83 & 30.23 \\
\hline $\begin{array}{l}\text { Minimum } \\
\text { (inches of mercury) }\end{array}$ & 28.52 & 28.79 & 28.50 & 28.33 & 28.10 \\
\hline $\begin{array}{l}\text { Total increases } \\
\text { (inches of mercury) }\end{array}$ & 49.98 & 46.04 & 51.46 & 49.97 & - \\
\hline $\begin{array}{l}\text { Total decrease } \\
\text { (inches of mercury) }\end{array}$ & 50.50 & 46.20 & 51.28 & 49.78 & - \\
\hline
\end{tabular}

"Source: Stone et al. (1983)

gross outliers. Some years have more storms than others. Further computations would show that the coupling of extremes with the average and standard deviations indicate a well-behaved and normal distribution of values. Final7y, 1988 was a leap year.

The total yearly breathing is 49.40 inches of mercury $(0.005639$ inches of mercury per hour) or about 1.69 atmospheres, which is somewhat lower than previous rates of about 2.2 atmospheres used in other studies (Klem 1991; Garfield 1975). Note that the present data gave breathing rates approaching 3 atmospheres before the few erroneous entries were corrected. Therefore, we bel ieve the 1.69 atmospheres ( 0.005639 inches of mercury per hour) annual breathing rate to be valid and the best available.

Note that the total hourly barometric movement (upward or downward changes being accumulated as separate accounts) are higher than would be determined from Stone et a1. (1983). For example, Table 36 in Stone et al. (1983) gives the annual average station pressure for hours 1 through 24 . From this, the average diurnal change from low to high is 0.04 inches of mercury, or about $30 \%$ of the movement determined by the present analysis from hourly changes. Although this is a natural rate, one needs to be aware that some tanks are actively being purged (through the Food Instrument Corporation level gauge or other instruments). These purges may be in excess of $0.71 \mathrm{~m}^{3} / \mathrm{h}$ $\left(25 \mathrm{ft}^{3} / \mathrm{h}\right)$, which is simitar to the natural breathing rate.

The data were examined on a daily basis to see if variations could be seen that were similar to the sinusoidal temperatures seen during the day. Those results for 1990 are presented (other years are very similar) as Table 2. Figure 1 is a graphical representation of the same data. There really is no trend over the day; in this case, Figure 1 is more enlightening than Table 2. Therefore, it would be impossible to predict that tank pressure would be high or low for any given hour of the day at some time in the future.

HNF-2483, Rev. 0

Tentin $3 / 3 / 1 / 45$

Page A-17

W320-28-001 rul

Pth

$4-3-95$ 
APPENDIX B

HNF-2483, Rev. 0

Page A-18
?. 3/31/55

28-001 reul Pth 4-3-95 





\%)

KAISER ENGINEERS HANFORD CO.

DUCT PRESSURE LOSS

CALCULATION SHEET

PREPARED BY: P.H. LANGOWSKI

DATE:

CHECKED BY:
3/28/95
NOTES:

Calculation W320-28-001.

$3^{n}$ schedule $80,1 \mathrm{D}=2.90^{4}$

Pressure loss per 1993 Fundamentals p.32.4 Darcy Equation (19).

Hydraulic diameter per 1993 Fundamentals p.32.6 Equation (24).

Reynold's Number per 1993 Fundamentals p.32.5 Equation (22)

ASHRAE fitting ED1-1 1993 Fundamentals p.32.29.
BLDG NO.I AREA

241-C-105/200E

Cascade Line from $\mathrm{C}-105$

to $\mathrm{C}-106$

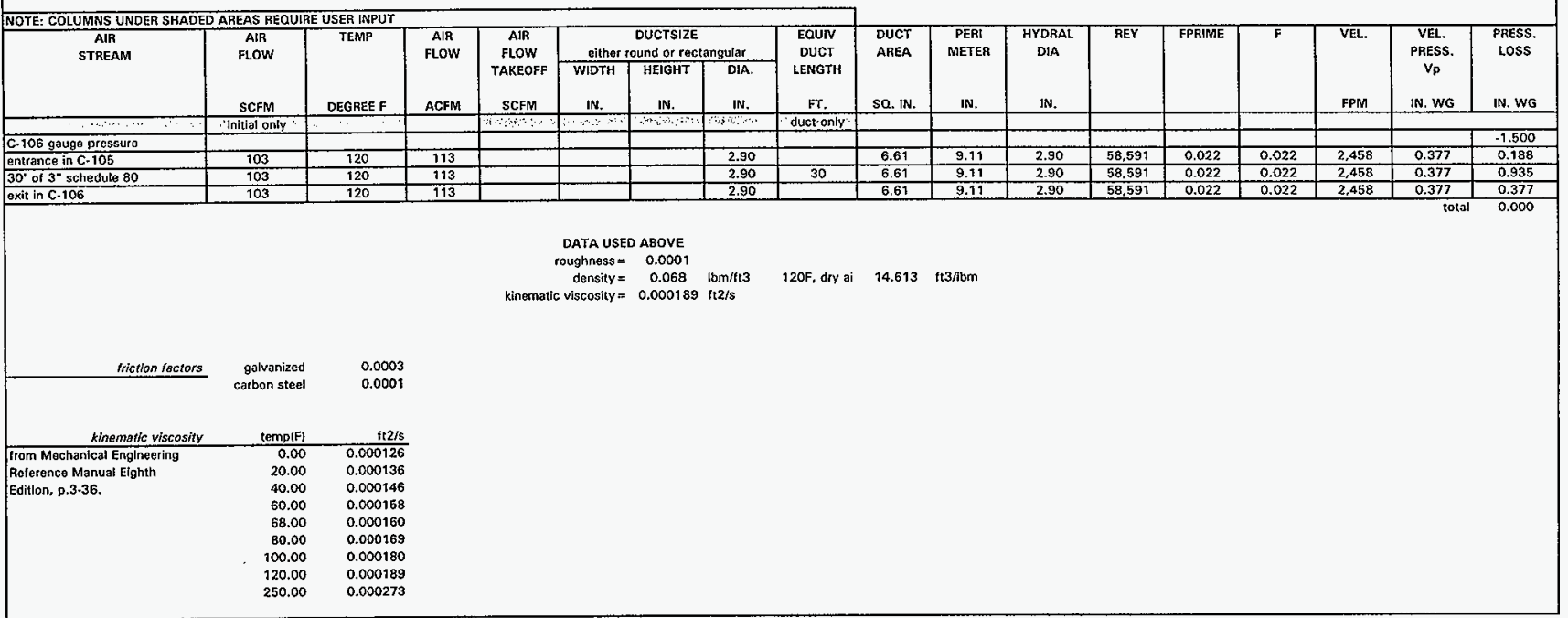

0
0
0
0
0
0
0
0
0
0
0
0
0 


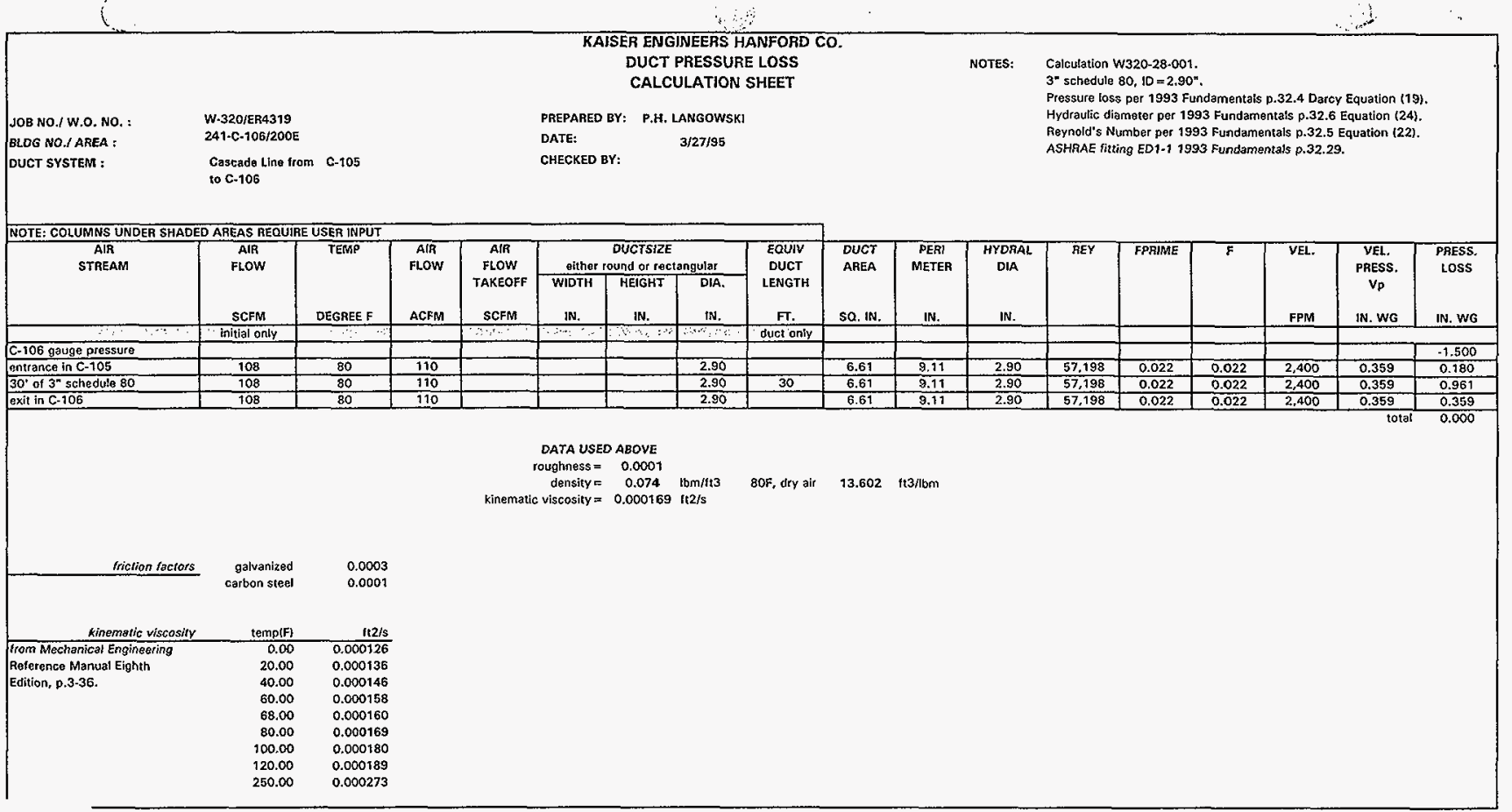

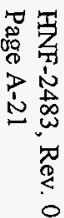


equals the difference between the upstream pressure, which is zero (atmospheric pressure), and the loss through the fitting. The static pressure of the ambient air is zero; several diameters downstream, static pressure is negative, algebraically equal to the total pressure (negative) and the velocity pressure (always positive).

System resistance to airflow is noted by the total pressure grade line in Figure 3. Sections 3 and 4 include fan system effect pressure losses. To obtain the fan static pressure requirement for fan selection where the fan total pressure is known, use:

$$
P_{s}=P_{t}-p_{n o}
$$

where

$P_{s}=$ fan static pressure, in. of water

$P_{1}=$ fan tocal pressure, in. of water

$p_{v, o}=$ fan outlet velocity pressure, in. of water

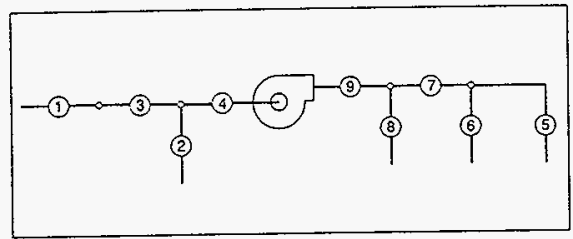

Fig. 2 Hustrative 6-Path, 9-Section System

\section{FLUID RESISTANCE}

Duct system losses are the irreversible transformation of mechanical energy into heat. The two types of losses are (1) frictional losses and (2) dynamic losses.

\section{FRICTIONAL LOSSES}

Frictional losses are due to fluid viscosity and are a result of momentum exchange between molecules in laminar flow and between particles moving at different velocities in turbulent flow. Frictional losses occur along the entire duct length.

\section{Darcy, Colebrook, and Altshul Equations}

For fluid flow in conduits, friction loss can be calculated by the Darcy equation:

$$
\Delta p_{f}=f\left(12 L / D_{h}\right) \rho(V / 1097)^{2}
$$

where

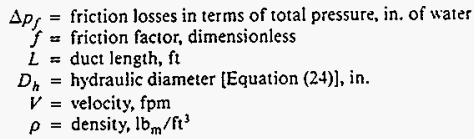

Within the region of laminar flow (Reynolds numbers less than 2000 ), the friction factor is a function of Reynolds number only.

HNF-2483, Rev. 0

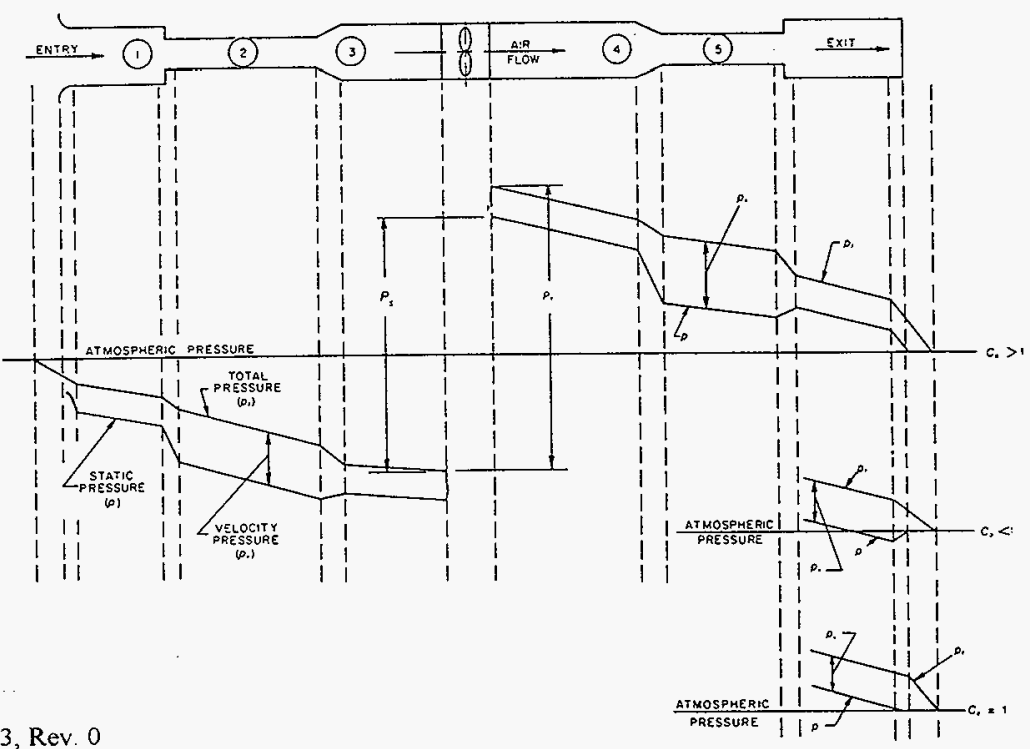

Page A-22

Fig. 3 Pressure Changes During Flow in Ducts 
For turbulent flow, the friction factor depends on Reynolds number, duct surface roughness, and internal protuberances such as joints. The traditional Moody chart depicts the behavior for round passages. For hydraulically smooth ducts, the friction factor again depends only on Reynolds number, but the dependence is markedly different from that for laminar flow. In general, for nonsmooth surfaces, the friction factor depends on roughness and Reynolds number; however, for a particular level of roughness beyond a sufficiently large Reynolds number, the friction factor becomes independent of Reynolds number, a flow condition considered as fully rough. Between the bounding limits of hydraulically smooth behavior and fully rough behavior, is a transitional roughness zone where the friction factor depends on both roughness and Reynolds number. In this transitionally rough, turbulent zone, where most cases of airflow occur in air-conditioning applications, the friction factor $f$ is calculated by Colebrook's equation (1938-39). Since this equation cannot be solved explicitly for $f$, use iterative techniques (Behls 1971).

$$
\frac{1}{f^{0.5}}=-2 \log \left[\frac{12 \epsilon}{3.7 D_{h}}+\frac{2.51}{\operatorname{Re} f^{0.5}}\right]
$$

where

$$
\begin{aligned}
\epsilon & =\text { material absolute roughness factor, } \mathrm{ft} \\
\mathrm{Re} & =\text { Reynolds number }
\end{aligned}
$$

A simplified formula for calculating friction factor, developed by Altshul (1975) and modified by Tsal, is

$$
\begin{gathered}
f^{\prime}=0.11\left(\frac{12 \epsilon}{D_{h}}+\frac{68}{\operatorname{Re}}\right)^{0.25} \\
\text { If } f^{\prime} \geqslant 0.018: \quad f=f^{\prime} \\
\text { If } f^{\prime}<0.018: \quad f=0.85 f^{\prime}+0.0028
\end{gathered}
$$

Friction factors obtained from Altshul's modified equation are within $1.6 \%$ of those obtained by Colebrook's equation. (22)

Reynolds number (Re) may be calculated by using Equation

$$
\operatorname{Re}=\frac{D_{h} V}{720 \nu}
$$

where $\nu=$ kinematic viscosity, $\mathrm{ft}^{2} / \mathrm{s}$.

For standard air, Re can be calculated by

$$
\operatorname{Re}=8.56 D_{h} V
$$

\section{Roughness Factors $(\epsilon)$}

The $\epsilon$-values listed in Table 1 are recommended for use with the Colebrook or Altshul-Tsal equation. These values should be interpreted as representing a combination of material, duct construction, joint type, and joint spacing (Griggs and Khodabakhsh-Sharifabad 1992). Roughness factors for other materials are presented in Idelchik et al. (1986). Idelchik summarizes roughness factors for 80 materials including metal tubes; conduits made from concrete and cement; and wood, plywood, and glass tubes.

Swim (1978) conducted tests on duct liners of varying densities, surface treatments, transverse joints (workmanship), and methods of at tachment to sheet metal ducts. As a result of these tests, Swim recommends for design $0.015 \mathrm{ft}$ for spray-coated liners and 0.005 $\mathrm{ft}$ for liners with a facing material cemented onto the air side. In both cases, the roughness factor includes the resistance offered by mechanical fasteners and assumes good joints. Liners cut too long and fastened to the duct cause much more loss than a liner cut too short; therefore, any fabrication error in liner length should be on the short side. Liner density does not significantly influence flow resistance.

Manufacturers' data indicate that the absolute roughness for fully extended nonmetallic flexible ducts ranges from 0.0035 to $0.015 \mathrm{ft}$. For fully extended flexible metallic ducts, absolute roughness ranges from 0.0004 to $0.007 \mathrm{ft}$. This range covers flexible duct with the supporting wire exposed to flow or covered by the material. Figure 4 provides a pressure drop correction factor for straight flexible duct when less than fully extended.

Table I Duct Roughness Factors

\begin{tabular}{ccc} 
Duct Material & $\begin{array}{c}\text { Roughness } \\
\text { Category }\end{array}$ & $\begin{array}{c}\text { Absolute } \\
\text { Roughness } \epsilon, \\
\mathrm{ft}\end{array}$ \\
\hline $\begin{array}{c}\text { Uncoated carbon steel, clean } \\
\text { (Moody } 1944)(0.00015 \mathrm{ft})\end{array}$ & Smooth & 0.0001
\end{tabular}

PVC plastic pipe (Swim 1982)

$(0.00003-0.00015 \mathrm{ft})$

Aluminum (Hutchinson 1953)

$(0.000015-0.0002 \mathrm{ft})$

\begin{tabular}{ccc}
\hline Galvanized steel, longitudinal seams, & Medium & \\
4-ft joints (Griggs et al. 1987) & smooth & 0.0003
\end{tabular}

\begin{tabular}{|c|c|c|}
\hline $\begin{array}{l}\text { Galvanized steel, longitudinal seams, } \\
2.5 \text {-ft joints (Wright } 1945)(0.0005 \mathrm{ft})\end{array}$ & Average & 0.0005 \\
\hline Fibrous glass duct, rigid & Medium & 0.003 \\
\hline $\begin{array}{l}\text { Fibrous glass duct liner, air side with } \\
\text { facing material (Swim 1978) }(0.005 \mathrm{ft})\end{array}$ & Rough & \\
\hline $\begin{array}{l}\text { Fibrous glass duct liner, air side spray } \\
\text { coated (Swim 1978) (0.015 ft) }\end{array}$ & Rough & 0.01 \\
\hline \multicolumn{3}{|l|}{$\begin{array}{l}\text { Flexible duct, metallic } \\
\qquad(0.004-0.007 \mathrm{ft} \text { when fully extended })\end{array}$} \\
\hline \multicolumn{3}{|l|}{$\begin{array}{l}\text { Flexible duct, all types of fabric and wite } \\
(0.0035-0.015 \mathrm{ft} \text { when fully extended })\end{array}$} \\
\hline $\begin{array}{l}\text { Concrete } \\
\text { (Moody 1944) }(0.001-0.01 \mathrm{ft})\end{array}$ & & \\
\hline
\end{tabular}

$(0.00016-0.00032 \mathrm{ft})$

Galvanized steel, continuously rolled, spiral seams, 10-ft joinis (Jones 1979) $(0.0002-0.0004 \mathrm{ft})$

Galvanized steel, spiral seam with 1, 2, and 3 ribs, 12-ft joints (Griggs et ol. 1987) $(0.00029-0.00038 \mathrm{ft})$

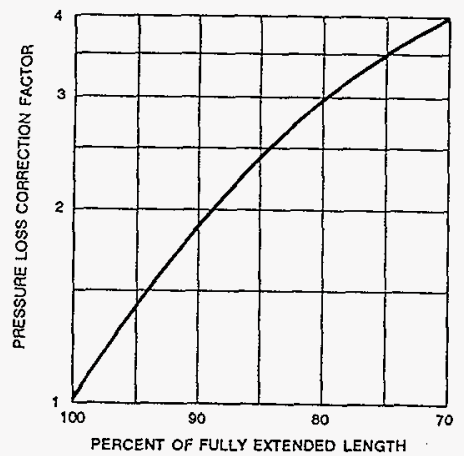

Fig. 4 Correction Factor for Unextended Flexible Duct

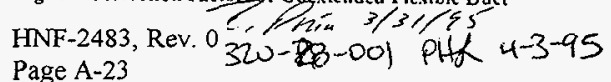




\section{Friction Chart}

Fluid resistance caused by friction in round ducts can be determined by the Friction Chart (Figure 5). This chart is based on standard air flowing through round galvanized ducts with beaded slip couplings on 48 -in. centers, equivalent to an absolute roughness of $0.0003 \mathrm{ft}$.

Changes in barometric pressure, temperature, and humidity affect air density, air viscosity, and Reynolds number. No corrections to the Friction Chart are needed for (1) duct materials with a medium smooth roughness factor, (2) temperature variations in the order of $\pm 30^{\circ} \mathrm{F}$ from $70^{\circ} \mathrm{F}$, (3) elevations to $1500 \mathrm{ft}$, and (4) duct pressures from -20 in. of water to $+20 \mathrm{in}$. of water relative to the ambient pressure. These individual variations in temperature, elevation, and duct pressure result in duct losses within $\pm 5 \%$ of the standard air friction chart.

For duct materials other than those categorized as medium smooth in Table 1, and for variations in temperature, barometric pressure (elevation), and duct pressures (outside the range listed), calculate the pressure loss in a duct due to friction by the AltshulTsal and Darcy equations [(21) and (19), respectively].

\section{Noncircular Ducts}

A momentum analysis can relate average wall shear stress to pressure drop per unit length for fully developed turbulent flow in a passage of arbitrary shape but of uniform longitudinal crosssectional area. Combining the result with the definition of the Darcy friction factor leads to Equation (24), with the ratio $4 A / P$ defined as hydraulic diameter:

$$
D_{h}=4 A / P
$$

where

$$
\begin{aligned}
D_{h} & =\text { hydraulic diameter, in. } \\
A & =\text { duct area, in } \\
P & =\text { perimeter of cross section, in. }
\end{aligned}
$$

While the hydraulic diameter is often used to correlate noncircular data, exact solutions for laminar flow in noncircular passages show that such practice causes some inconsistencies. No exact solutions exist for turbulent flow. Tests over a limited range of turbulent flow indicated that fluid resistance is the same for equal lengths of duct for equal mean velocities of flow if the ducts have the same ratio of cross-sectional area to perimeter. From a series of experiments using round, square, and rectangular ducts having essentially the same hydraulic diameter, Huebscher (1948) found that each, for most purposes, had the same flow resistance at equal mean velocities. Tests by Griggs and KhodabakhshSharifabad (1992) also indicated that experimental rectangular duct data for airflow over the range typical of HVAC systems can be correlated satisfactorily using Equation (20) together with hydraulic diameter, particularly when a realistic experimental uncertainty is accepted. These tests support using hydraulic diameter to correlate noncircular duct data.

Rectangular ducts. Huebscher developed the relationship between rectangular and round ducts that is used to determine size equivalency based on equal flow, resistance, and length. This relationship, Equation (25), is the basis for Table 2.

$$
D_{\mathrm{e}}=1.30 \frac{(a b)^{0.625}}{(a+b)^{0.250}}
$$

$$
\begin{aligned}
& \text { where } \\
& \qquad \begin{aligned}
D_{e}= & \text { circular equivalent of rectangular duct for equal length, } \\
& \text { fluid resistance, and airflow, in. }
\end{aligned} \\
& a=\text { length of one side of duct, in. } \\
& b=
\end{aligned}
$$

To size retangular ducts, determine the circular duct diameter by any design method, and use Table 2 to select the equisalent duct size as a function of aspect ratio. Equations (21) or (20) and (19) must be used to determine pressure loss.

Flat oval ducts. To convert round ducts to spiral flat oval sizes, use Table 3. Table 3 is based on Equation (26) (Heyt and Diaz 1975), the circular equivalent of a flat oval duct for equal airflow, resistance, and length. Equations (21) or (20) and (19) must be used to determine frictional pressure loss.

$$
D_{c}=\frac{1.55 A^{0.625}}{P^{0.250}}
$$

where $A$ is the cross-sectional area of flat oval duct defined as:

$$
A=\left(\pi b^{2} / 4\right)+b(a-b)
$$

and the perimeter $P$ is calculated by:

$$
P=\pi b+2(a-b)
$$

where

$$
\begin{aligned}
& P=\text { perimeter of flat oval duct, in. } \\
& a=\text { major dimension of flat oval duct, in. } \\
& b=\text { minor dimension of flat oval duct, in. }
\end{aligned}
$$

\section{DYNAMIC LOSSES}

Dynamic losses result from flow disturbances caused by fittings that change the airflow path's direction and/or area. These fittings include entries, exits, transitions, and junctions. Idelchik (1986) discusses parameters affecting fluid resistance of fittings and presents loss coefficients in three forms: tables, curves, and equations.

\section{Local Loss Coefficients}

The following dimensionless coefficient is used for fluid resistance, since this coefficient has the same value in dynamically similar streams, i.e., streams with geometrically similar stretches, equal values of Reynolds number, and equal values of other criteria necessary for dynamic similarity. The fluid resistance coefficient represents the ratio of total pressure loss to velocity pressure at the referenced cross section.

$$
C=\frac{\Delta p_{j}}{\rho(V / 1097)^{2}}=\frac{\Delta p_{j}}{p_{i}}
$$

where

$C=$ local loss coefficient, dimensionless

$\Delta p_{j}=$ fitting total pressure loss, in. of water

$\rho=$ density, $1 b_{m} / \mathrm{ft}^{3}$

$V=$ velocity, $f \mathrm{pm}$

$p_{v}=$ velocity presstre, in. of water

Dynamic losses occur along a duct length and cannot be separated from frictional losses. For ease of calculation, dynamic losses are assumed to be concentrated at a section (local) and to exclude friction. Frictional losses must be considered only for relatively long fittings. Generally, fitting friction losses are accounted for by measuring duct lengths from the centerline of one fitting to that of the next fitting. For fittings closely coupled (less than six hydraulic diameters apart), the flow pattern entering subsequent fittings differs from the flow pattern used to determine loss coefficients. Adequate data for these situations are unavailable.

For all fittings, except junctions, calculate the total pressure loss $\Delta p$, at a section by:

HNF-2483, Rev. 0

Page A-24 
CD9-3 Fire Damper, Curtain Type, Type C

$$
C_{0}=0.12
$$

ED1-1 Duct Mounted in Wall (Ideichik et al. 1986, Diagram 3-1)

$$
C_{0} \text { Values }
$$

$$
L / D
$$

\begin{tabular}{rrrrrrrrrrr}
$t / D$ & 0.000 & 0.002 & 0.010 & 0.050 & 0.100 & 0.200 & 0.300 & 0.500 & 10.000 \\
\hline 0.00 & 0.50 & 0.57 & 0.68 & 0.80 & 0.86 & 0.92 & 0.97 & 1.00 & 1.00 \\
0.02 & 0.50 & 0.51 & 0.52 & 0.55 & 0.60 & 0.66 & 0.69 & 0.72 & 0.72 \\
0.05 & 0.50 & 0.50 & 0.50 & 0.50 & 0.50 & 0.50 & 0.50 & 0.50 & 0.50 \\
10.00 & 0.50 & 0.50 & 0.50 & 0.50 & 0.50 & 0.50 & 0.50 & 0.50 & 0.50 \\
\hline
\end{tabular}

\begin{tabular}{|c|c|c|c|c|c|c|c|c|c|c|c|}
\hline \multicolumn{12}{|c|}{$C_{o}$ Values } \\
\hline \multicolumn{12}{|c|}{$L / D_{0}$} \\
\hline$A_{1} / A_{o}$ & 0.5 & 1.0 & 2.0 & 3.0 & 4.0 & 5.0 & 6.0 & 8.0 & 10.0 & 12.0 & 14.0 \\
\hline 1.5 & 0.03 & 0.02 & 0.03 & 0.03 & 0.04 & 0.05 & 0.06 & 0.08 & 0.10 & 0.11 & 0.13 \\
\hline 2.0 & 0.08 & 0.06 & 0.04 & 0.04 & .0 .04 & 0.05 & 0.05 & 0.06 & 0.08 & 0.09 & 0.10 \\
\hline 2.5 & 0.13 & 0.09 & 0.06 & 0.06 & 0.06 & 0.06 & 0.06 & 0.06 & 0.07 & 0.08 & 0.09 \\
\hline 3.0 & 0.17 & 0.12 & 0.09 & 0.07 & 0.07 & 0.06 & 0.06 & 0.07 & 0.07 & 0.08 & 0.08 \\
\hline 4.0 & 0.23 & 0.17 & 0.12 & 0.10 & 0.09 & 0.08 & 0.08 & 0.08 & 0.08 & 0.08 & 0.08 \\
\hline 6.0 & 0.30 & 0.22 & 0.16 & 0.13 & 0.12 & 0.10 & 0.10 & 0.09 & 0.09 & 0.09 & 0.08 \\
\hline 8.0 & 0.34 & 0.26 & 0.18 & 0.15 & 0.13 & 0.12 & 0.11 & 0.10 & 0.09 & 0.09 & 0.09 \\
\hline 10.0 & 0.36 & 0.28 & 0.20 & 0.16 & 0.14 & 0.13 & 0.12 & 0.11 & 0.10 & 0.09 & 0.09 \\
\hline 14.0 & 0.39 & 0.30 & 0.22 & 0.18 & 0.16 & 0.14 & 0.13 & 0.12 & 0.10 & 0.10 & 0.10 \\
\hline 20.0 & 0.41 & 0.32 & 0.24 & 0.20 & 0.17 & 0.15 & 0.14 & 0.12 & 0.11 & 0.11 & 0.10 \\
\hline \multicolumn{12}{|c|}{ Optimum Angie, $\theta$} \\
\hline $\boldsymbol{A}_{1} / A_{0}$ & 0.5 & 1.0 & 2.0 & 3.0 & 4.0 & 5.0 & 6.0 & 8.0 & 10.0 & 12.0 & 14.0 \\
\hline 1.5 & 34 & 20 & 13 & 9 & 7 & 6 & 4 & 3 & 2 & 2 & 2 \\
\hline 2.0 & 42 & 28 & 17 & 12 & 10 & 9 & 8 & 6 & 5 & 4 & 3 \\
\hline 2.5 & so & 32 & 20 & 15 & 12 & 11 & 10 & 8 & 7 & 6 & 5 \\
\hline 3.0 & 54 & 34 & 22 & 17 & 14 & 12 & 11 & 10 & 8 & 8 & 6 \\
\hline 4.0 & 58 & 40 & 26 & 20 & 16 & 14 & 13 & 12 & 10 & 10 & 9 \\
\hline 6.0 & 62 & 42 & 28 & 22 & 19 & 16 & 15 & 12 & 11 & 10 & 9 \\
\hline 8.0 & 64 & 44 & 30 & 24 & 20 & 18 & 16 & 13 & 12 & 11 & 10 \\
\hline 10.0 & 66 & 46 & 30 & 24 & 22 & 19 & 17 & 14 & 12 & [1] & 10 \\
\hline 14.0 & 66 & 48 & 32 & 26 & 22 & 19 & 17 & 14 & 13 & 11 & 11 \\
\hline 20.0 & 68 & 48 & 32 & 26 & 22 & 20 & 18 & is & 13 & 12 & 11 \\
\hline
\end{tabular}

ED2-1 Conical Diffuser, Round to Plenum, Exhaust/Return Systems (Idelchik et al. 1986, Diagram 5-8)
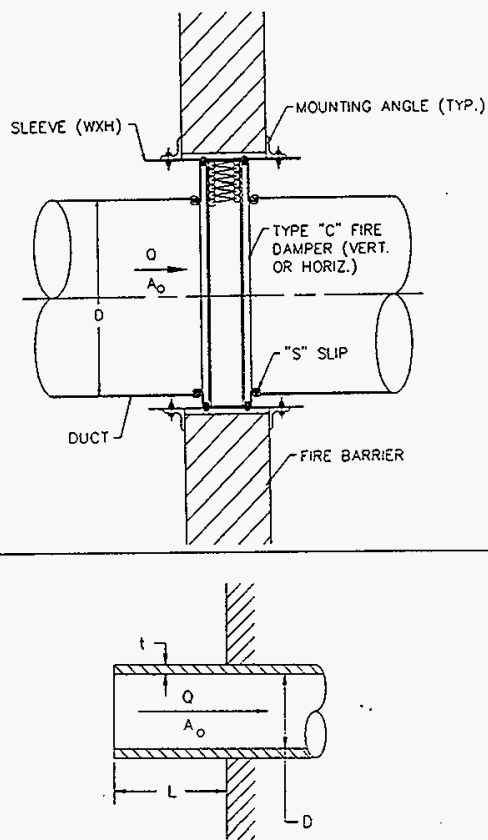

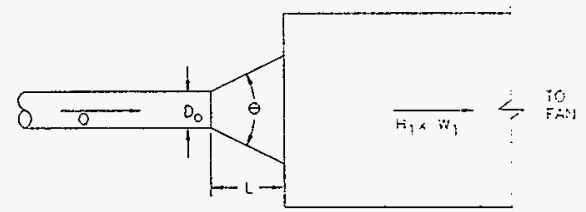

HNF-2483, Rev. 0 
Appendix F

Dimenslons of Welded and Sermless Steel Plpe

\begin{tabular}{|c|c|c|c|c|c|c|c|}
\hline $\begin{array}{l}\text { Nominal } \\
\text { Dlameter }\end{array}$ & & $\begin{array}{c}\text { Outslde } \\
\text { Dlameter }\end{array}$ & $\begin{array}{c}\text { Wall } \\
\text { Thlckness }\end{array}$ & $\begin{array}{c}\text { Internal } \\
\text { Dlameter }\end{array}$ & $\begin{array}{c}\text { Internal } \\
\text { Area } \\
\end{array}$ & $\begin{array}{c}\text { Internal } \\
\text { Dlameter }\end{array}$ & $\begin{array}{c}\text { Internal } \\
\text { Area }\end{array}$ \\
\hline Inches & Schedule & Inches & Inches & Inches & Sq inches & Feet & SQ Feet \\
\hline$\frac{1}{8}$ & $\begin{array}{l}40(S) \\
80(X)\end{array}$ & 0.405 & $\begin{array}{l}0.068 \\
0.095\end{array}$ & $\begin{array}{l}0.289 \\
0.215\end{array}$ & $\begin{array}{l}0.0568 \\
0.0363\end{array}$ & $\begin{array}{l}0.0224 \\
0.0179\end{array}$ & $\begin{array}{l}0.00039 \\
0.00025\end{array}$ \\
\hline$\frac{1}{4}$ & $\begin{array}{l}40(S) \\
80(X)\end{array}$ & 0.540 & $\begin{array}{l}0.088 \\
0.118\end{array}$ & $\begin{array}{l}0.364 \\
0.302\end{array}$ & $\begin{array}{l}0.1041 \\
0.0718\end{array}$ & $\begin{array}{l}0.0303 \\
0.0252\end{array}$ & $\begin{array}{l}0.00072 \\
0.00050\end{array}$ \\
\hline$\frac{3}{8}$ & $\begin{array}{l}40(S) \\
80(X)\end{array}$ & 0.675 & $\begin{array}{l}0.091 \\
0.126\end{array}$ & $\begin{array}{l}0.493 \\
0.423\end{array}$ & $\begin{array}{l}0.1809 \\
0.1405\end{array}$ & $\begin{array}{l}0.0411 \\
0.0353\end{array}$ & $\begin{array}{l}0.00133 \\
0.00098\end{array}$ \\
\hline$\frac{1}{2}$ & $\begin{array}{r}40(\mathrm{~S}) \\
80(\mathrm{X}) \\
160 \\
(\mathrm{XX})\end{array}$ & 0.840 & $\begin{array}{l}0.108 \\
0.147 \\
0.187 \\
0.294\end{array}$ & $\begin{array}{l}0.822 \\
0.546 \\
0.46 B \\
0.252\end{array}$ & $\begin{array}{c}0.3039 \\
0.2341 \\
0.1708 \\
0.498\end{array}$ & $\begin{array}{l}0.0518 \\
0.0455 \\
0.0388 \\
0.0210\end{array}$ & $\begin{array}{l}0.00211 \\
0.00163 \\
0.00118 \\
0.00035\end{array}$ \\
\hline$\frac{3}{4}$ & $\begin{array}{r}40(S) \\
80(X) \\
160 \\
(X X)\end{array}$ & 1.050 & $\begin{array}{l}0.113 \\
0.154 \\
0.219 \\
0.308\end{array}$ & $\begin{array}{l}0.824 \\
0.742 \\
0.812 \\
0.434\end{array}$ & $\begin{array}{l}0.5333 \\
0.4324 \\
0.2942 \\
0.1478\end{array}$ & $\begin{array}{l}0.0887 \\
0.0618 \\
0.0510 \\
0.0362\end{array}$ & $\begin{array}{l}0.00370 \\
0.00300 \\
0.00204 \\
0.00103\end{array}$ \\
\hline 1 & $\begin{array}{r}40(S) \\
80(X) \\
160 \\
(X X)\end{array}$ & 1.315 & $\begin{array}{l}0.133 \\
0.179 \\
0.250 \\
0.358\end{array}$ & $\begin{array}{l}1.049 \\
0.957 \\
0.815 \\
0.599\end{array}$ & $\begin{array}{l}0.8643 \\
0.7193 \\
0.5217 \\
0.2818\end{array}$ & $\begin{array}{l}0.0874 \\
0.0798 \\
0.0879 \\
0.0499\end{array}$ & $\begin{array}{l}0.00600 \\
0.00500 \\
0.00362 \\
0.00196\end{array}$ \\
\hline $1 \frac{1}{4}$ & $\begin{array}{r}40(S) \\
80(X) \\
160 \\
(X X)\end{array}$ & 1.660 & $\begin{array}{l}0.140 \\
0.191 \\
0.250 \\
0.382\end{array}$ & $\begin{array}{l}1.380 \\
1.278 \\
1.160 \\
0.806\end{array}$ & $\begin{array}{c}1.496 \\
1.283 \\
1.057 \\
0.6305\end{array}$ & $\begin{array}{l}0.1150 \\
0.1065 \\
0.0967 \\
0.0747\end{array}$ & $\begin{array}{l}0.01039 \\
0.00880 \\
0.00734 \\
0.00438\end{array}$ \\
\hline $1 \frac{1}{2}$ & $\begin{array}{r}40(\mathrm{~S}) \\
80(\mathrm{X}) \\
160 \\
(\mathrm{XX})\end{array}$ & 1.000 & $\begin{array}{l}0.145 \\
0.200 \\
0.281 \\
0.400\end{array}$ & $\begin{array}{l}1.810 \\
1.500 \\
1.338 \\
1.100 \\
\end{array}$ & $\begin{array}{c}2.038 \\
1.767 \\
1.408 \\
0.8503 \\
\end{array}$ & $\begin{array}{l}0.1342 \\
0.1250 \\
0.1115 \\
0.0817\end{array}$ & $\begin{array}{l}0.01414 \\
0.01227 \\
0.00978 \\
0.00880\end{array}$ \\
\hline 2 & $\begin{array}{r}40(S) \\
80(X) \\
180 \\
(X X)\end{array}$ & 2.375 & $\begin{array}{l}0.154 \\
0.218 \\
0.344 \\
0.436\end{array}$ & $\begin{array}{l}2.087 \\
1.039 \\
1.687 \\
1.503\end{array}$ & $\begin{array}{l}3.358 \\
2.953 \\
2.235 \\
1.774\end{array}$ & $\begin{array}{l}0.1723 \\
0.1616 \\
0.1406 \\
0.1253\end{array}$ & $\begin{array}{l}0.02330 \\
0.02051 \\
0.01552 \\
0.01232\end{array}$ \\
\hline $2 \frac{1}{2}$ & $\begin{array}{r}10(S) \\
80(X) \\
160 \\
(X X)\end{array}$ & 2.875 & $\begin{array}{l}0.203 \\
0.276 \\
0.375 \\
0.552\end{array}$ & $\begin{array}{l}2.189 \\
2.323 \\
2.125 \\
1.771\end{array}$ & $\begin{array}{l}4.788 \\
4.238 \\
3.547 \\
2.464\end{array}$ & $\begin{array}{l}0.2058 \\
0.1936 \\
0.1771 \\
0.1476\end{array}$ & $\begin{array}{l}0.03325 \\
0.02943 \\
0.02483 \\
0.01711\end{array}$ \\
\hline 3 & $\begin{array}{r}10(\mathrm{~S}) \\
80(\mathrm{X}) \\
160 \\
(\mathrm{XX})\end{array}$ & 3.500 & $\begin{array}{l}0.216 \\
0.300 \\
0.438 \\
0.600\end{array}$ & $\begin{array}{l}3.088 \\
2.900 \\
2.624 \\
2.300\end{array}$ & $\begin{array}{l}7.383 \\
6.605 \\
5.108 \\
4.155\end{array}$ & $\begin{array}{l}0.2557 \\
0.2117 \\
0.2187 \\
0.1017\end{array}$ & $\begin{array}{l}0.05134 \\
0.04587 \\
0.03755 \\
0.02885\end{array}$ \\
\hline $3 \frac{1}{2}$ & $\begin{array}{l}40(S) \\
80(X)\end{array}$ & 4.000 & $\begin{array}{l}0.228 \\
0.318\end{array}$ & $\begin{array}{l}3.548 \\
3.364\end{array}$ & $\begin{array}{l}0.887 \\
8.888\end{array}$ & $\begin{array}{l}0.2957 \\
0.2803\end{array}$ & $\begin{array}{l}0.06886 \\
0.08172\end{array}$ \\
\hline 4 & $\begin{array}{r}40(S) \\
80(\mathrm{X}) \\
120 \\
160 \\
(\mathrm{XX})\end{array}$ & 4.500 & $\begin{array}{l}0.237 \\
0.337 \\
0.438 \\
0.831 \\
0.674\end{array}$ & $\begin{array}{l}4.026 \\
3.826 \\
3.624 \\
3.438 \\
3.152\end{array}$ & $\begin{array}{l}12.73 \\
11.50 \\
10.32 \\
9.283 \\
7.803\end{array}$ & $\begin{array}{l}0.3355 \\
0.3188 \\
0.3020 \\
0.2885 \\
0.2827\end{array}$ & $\begin{array}{l}0.08841 \\
0.07984 \\
0.07163 \\
0.06447 \\
0.05419\end{array}$ \\
\hline
\end{tabular}




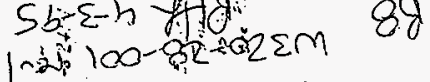

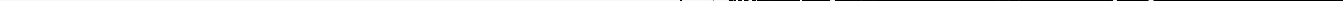


HNF-2483, Rev. 0

W320-28-001

Equipment Sizing \& Selection

Recirculation Fan

B-i 
This sheet shows the status and description of the attached Design Analysis sheets.

Discipline 28/HVAC wo/Job No. ER4319

Calculation No. W320-

Project No. \& Name W-320 Tank 241-C-106 Waste Retrieval

Calculation Item Equipment Sizing \& Selection Recirculation Fan

These calculations apply to:

Dwg. No. N/A

Rev. No. N/A

Dwg. No. N/A

Rev. No. N/A

Other (Study. CDR)

Procurement Specifications:

W-320-P6 Recirculation fan

Rev. No. 0

The status of these calculations is:

[] Preliminary Calculations

[X] Final Calculations

[] Check Calculations (On Calculation Dated)

[] Void Calculation (Reason Voided)

Incorporated in Final Drawings?

[] Yes $[X]$ No

This calculation verified by independent "check" calculations? [] Yes [X] No No

Original and Revised Calculation Approvals:

\begin{tabular}{|c|c|}
\hline & $\begin{array}{c}\text { Rev. }{ }^{2} \\
\text { Signature/Date }\end{array}$ \\
\hline Originator & \\
\hline Checked by & \\
\hline Approved by & \\
\hline $\begin{array}{l}\text { Checked Against } \\
\text { Approved Vendor } \\
\text { Data }\end{array}$ & \\
\hline
\end{tabular}

Design

Analysis

INDEX

Page No.

Description

\begin{tabular}{|l|l|}
\hline$i$ & Calculation Identification and Index \\
\hline 1 & Objective, Design Inputs, \& Calculations \\
\hline 2 & Findings \& Conclusions \\
\hline A1-A10 & Appendix A: Supporting Information \\
\hline
\end{tabular}




\section{DESIGN ANALYSIS}

Client WHC

Subject Equipment Sizing \& Selection.

Recirculation Fan

Location 241-C/200 East
WO/Job No. ER4319

Date 3-6-95

Checked 3.8 .95

Revised
By PH Langowski PH

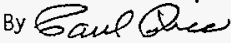

By

\subsection{OBJECTIVE}

The objective of this calculation is to determine the performance requirements of the recirculation fan.

\subsection{DESIGN INPUTS}

\subsection{CRITERIA AND SOURCE}

DOE General Order 6430.1A

Functional Design Criteria WHC-SD-W320-FDC-001, rev, 2, 1/18/94

\subsection{GIVEN DATA}

1. Energy Balance drawing $\mathrm{H}-2-818479$ which gives normal fan operation of $77 \mathrm{~F}$ fan inlet air conditions.

\subsection{ASSUMPTIONS}

1. Pressure drop through the condenser is linear with reduced airflow.

2. Pressure drop through the moisture separator is governed by the square of the velocity ratio of the design airflow to the actual operating point airflow (based on Wright-Austin vendor data).

\subsection{METHODS}

Hand calculations, Excel spreadsheet, vendor information.

\subsection{REFERENCE $\$ 28$}

W320-H-018, rev 1 Calculation. Pressure Drop Calculations for Exhaust Skid Sizing

W320-K1-015, rev 0 Calculation. Moisture Separator Sizing

1997 ASHRAE Fundamentals

$28^{\prime}$

\subsection{CALCULATIONS 28}

From $W 320-\not K-015$ para $7.4,54637 b_{\mathrm{da}} / \mathrm{h}$ at a $40 \mathrm{~F}$ saturated humidity ratio of $0.005216 \mathrm{lb}_{\mathrm{w}} / 7 \mathrm{~b}_{\text {da }}$ yields $28.49 \mathrm{ib} / \mathrm{h}$ (vapor) leaving the condenser. From the same calculation para 7.5 it is shown that $0.77 \mathrm{~b} / \mathrm{min}$ (mist) enters the moisture separator and $0.56 \mathrm{lb} / \mathrm{min}$ (mist) is removed by the moisture separator. Therefore, $(0.14$ $\left.7 \mathrm{~b}_{\mathrm{w}} / \mathrm{min}\right)(60 \mathrm{~min} / \mathrm{h})=8.4 \mathrm{lb} / \mathrm{h}$ of mist is leaving the moisture separator.

The humidity ratio of the airstream is therefore $(28.49+8.4) 1 \mathrm{~b}_{w} / \mathrm{h} / 54637 \mathrm{~b} \delta \mathrm{h}$ $=0.0067537 \mathrm{~b}_{\mathrm{w}} / 1 \mathrm{~b}_{\mathrm{sa}}$. At the $77 \mathrm{~F}$ temperature exiting the heating coil with a saturated humidity ratio of $0.0201701 \mathrm{~b}_{w} / 7 \mathrm{~b}_{\mathrm{ca}}$ for $77 \mathrm{~F}$, the relative humidity is

\section{$0.006753 / 0.020170=33 \%$.}

From the psychrometric chart (App A), at $77 \mathrm{~F}$ and $33 \% \mathrm{RH}$, the specific volume is $13.569 \mathrm{ft}^{3} / 1 \mathrm{~b}_{\mathrm{da}}\left(0.07371 \mathrm{~b}_{\mathrm{da}} / \mathrm{ft}^{3}\right)$. At 500 feet elevation the standard atmosphere is 14.430 psia which is equivalent to $(14.430)(27.708)=399.83^{\prime \prime}$ water absolute $[(14.696)(27.708)=407.20 "$ water absolute at sea level]. Using ideal gas laws, a density factor of $399.83 / 407.20=0.982$ accounts for a 500 foot elevation difference and yields $(0.982)(0.0737)=0.0724 \mathrm{lb}_{\mathrm{d} a} / \mathrm{ft}^{3}$. The specification $\mathrm{P} 6$ was completed with 
client WHC

Subject Equipment Sizing \& Selection.

Recirculation Fan

Location 241-C/200 East

\section{DESIGN ANALYSIS}

an inlet air density of $0.07041 \mathrm{~b}_{\mathrm{da}} / \mathrm{ft}^{3}$, which is within three percent of that calculated at 500 foot elevation. At a slightly higher elevation the air density would be even closer to that listed in the specification.

An upset condition where the condenser is off line and the tank is at a $120 \mathrm{~F}$ operating limit condition is based on FOC equipment operating limits for tank installed equipment. The assumed $100 \%$ saturation at this upset condition yields a $0.06051 \mathrm{~b} / \mathrm{ft}^{3}$ density. The fan should be sized to. be away from the top of it's curve between thez 8 normal and upset operating points so as to not induce pulsations. Using the W320-KK-018 spreadsheet with $120 \mathrm{~F}$ saturated air and the airflows set at 600,750 , 'and $860 \mathrm{scfm}$ for the recirculation fan yields a system curve for this temperature (App A spreadsheet printout results are plotted on top of vendor fan curve on page A4). Intersection of an upset system curve with the vendor fan curve at this upset condition shows that at $120 \mathrm{~F}$ the fan will move approximately 850 acfm at a $16.8^{\prime \prime} \mathrm{W.g}$. pressure differential.

\subsection{FINDINGS \& CONCLUSIONS}

The recirculation fan sizing design operating point will be: 860 scfm (916 acfm) (a 19.0" water gauge static pressure differential and a $77 \mathrm{~F}$ inlet air density of 0.0704 $\mathrm{ib} / \mathrm{ft}^{3}$. The maximum assumed upset operating temperature is $120 \mathrm{~F}$ (saturated) with an inlet air density of $0.0605 \mathrm{lb} / \mathrm{ft}^{3}$. At the $120 \mathrm{~F}$ upset condition, the fan wi 7 move approximately 850 acfm at a $16.8^{\prime \prime} \mathrm{W} . \mathrm{g}$. pressure differential and operation should be stable.

3.0 Calcutation vapor Lenving condeneser $=28.49$ eff thr lot. of air throngh condevterer: $5463 \mathrm{lb} \mathrm{da} / \mathrm{h}$.

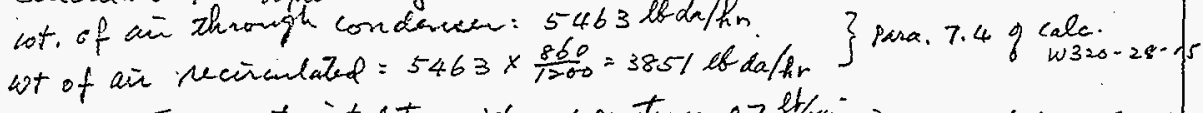

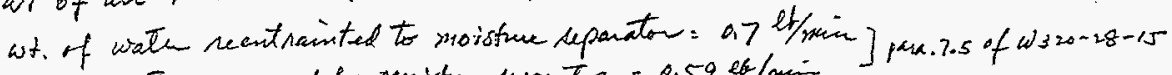

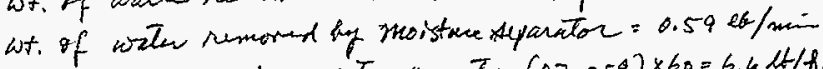
wiof water leavig moistremspreater $(0.7-0.54) \times 60=6.6 \mathrm{lt} / \mathrm{hn}$.

Humiditg ratio fer ais leving heating cail

$(28.49+6.6) \% 3851=0.0091$ l6w/lita

R.t. of are leaving hesing coil $=0.0091 / 0.020170=45.18 \%$

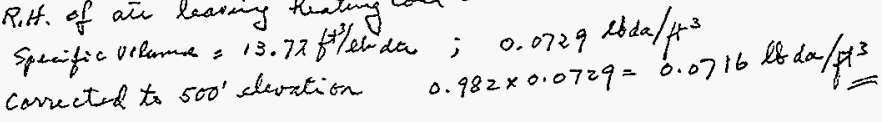

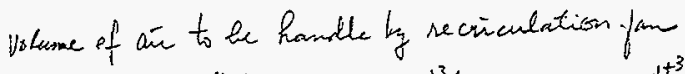

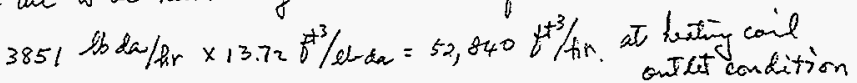

$$
\text { or } 880 \mathrm{ft}^{+3} / \mathrm{min}
$$

HNF-2483, Rev. 0

Page B-3 
APPENDIX A

HNF-2483, Rev. 0

Page B-4 
ASHRAE PSYCHROMETRIC CHART NO.

NORMAL TEMPERATURE

$$
\text { CORYRISHT ISE3 }
$$

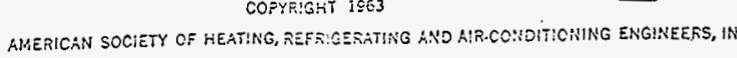

SEA LEVEL
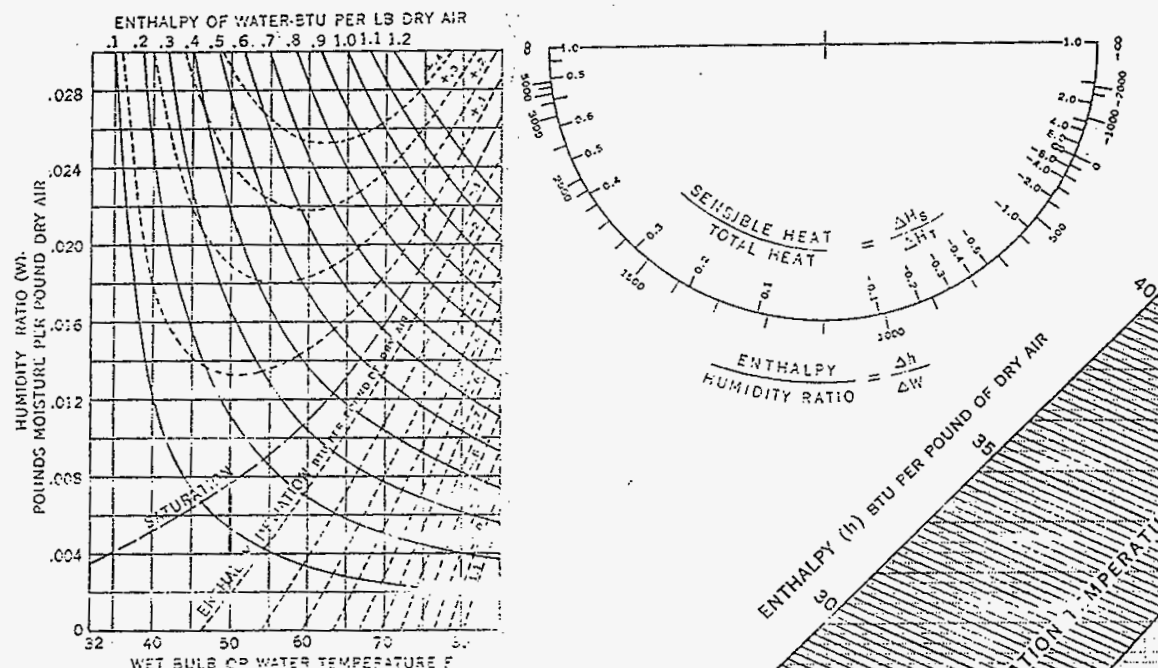

(3)

to 50 a 60 -

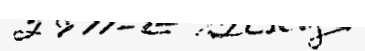

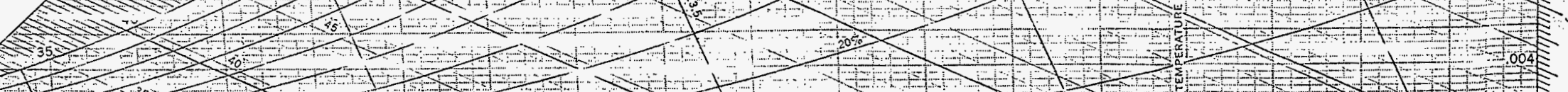

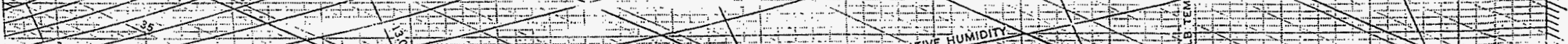

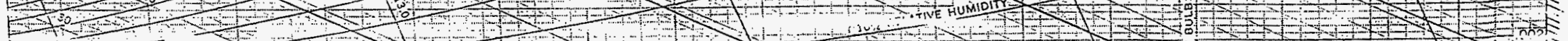

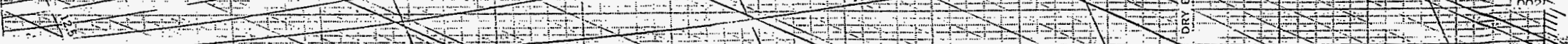
Non,

HNF-2483, Rev. 0 Page B-5

$$
\text { A1 } \quad \text { PHe } 3645
$$

77

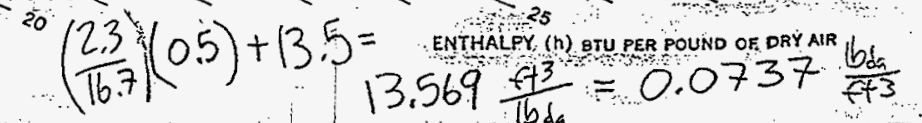




DAVID W. MCKENZIE, INC.
Air Handling Equipment
P.O. Box 728, Bcilevuc, WA 98009
Phone Number: 206-454-4666
Fax Number: 206-562-1169

Date: 02-09-95

Number of Pages (Inclk: äing Cover Page): 3

TO: PETER LANGOWSKI

KAISER ENGINEERS HANFORD

Fax Number: $509-373-3343$

$R E$ :

RECIRCULATION \& EXIIAUST FANS

FAN ENGINEERING COMPANY

\section{Message:}

Enclosed are performance curves for the design dersity of $0.0704 \mathrm{lb} / \mathrm{cu} f \mathrm{f}$ and the upset density of $0.0605 \mathrm{lb} / \mathrm{cu} \mathrm{ft}$.

As we discussed, the basic fan and motor size remains the same. The fan wheel diameter will increase from $17^{\prime \prime}$ to $18.25^{\prime \prime}$.

Information on the clutch for preventing backflow has been forwarded to the factory. It appears as though the overall length of the assembly will increase with the addition of this device. There will be no change in the fan centerline height or in the relationship between the inlet and discharge. I will advise you of any changes as soon as I hear from the factory.

Please call whenever I can be of assistarce.

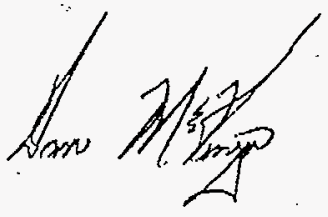




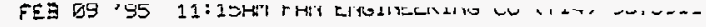

STATIC PRESSURE - INCHES H.G.

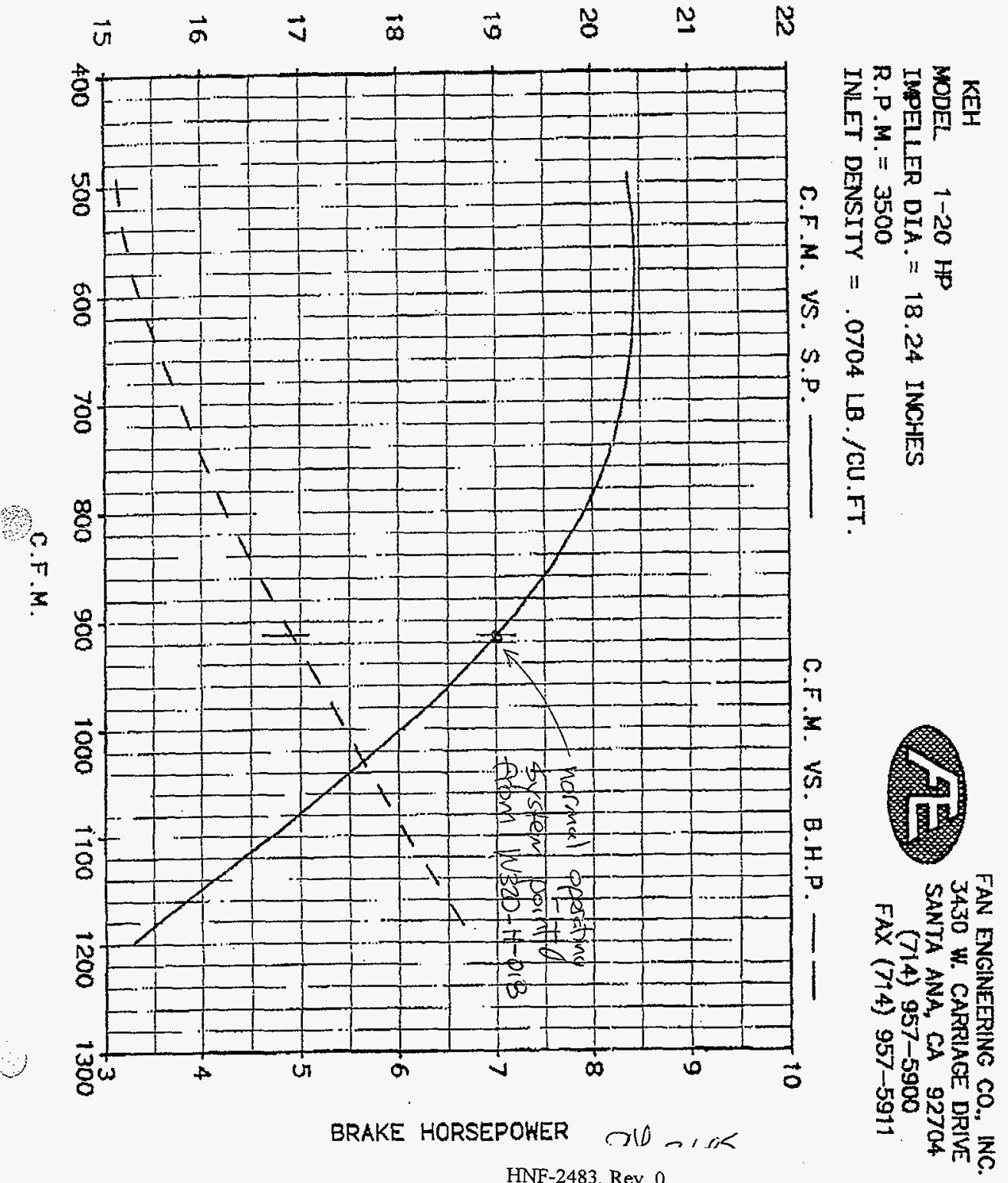

HNF-2483, Rev. 0

Page B-7 
STATIC PRESSURE - INCHES $14, G$.

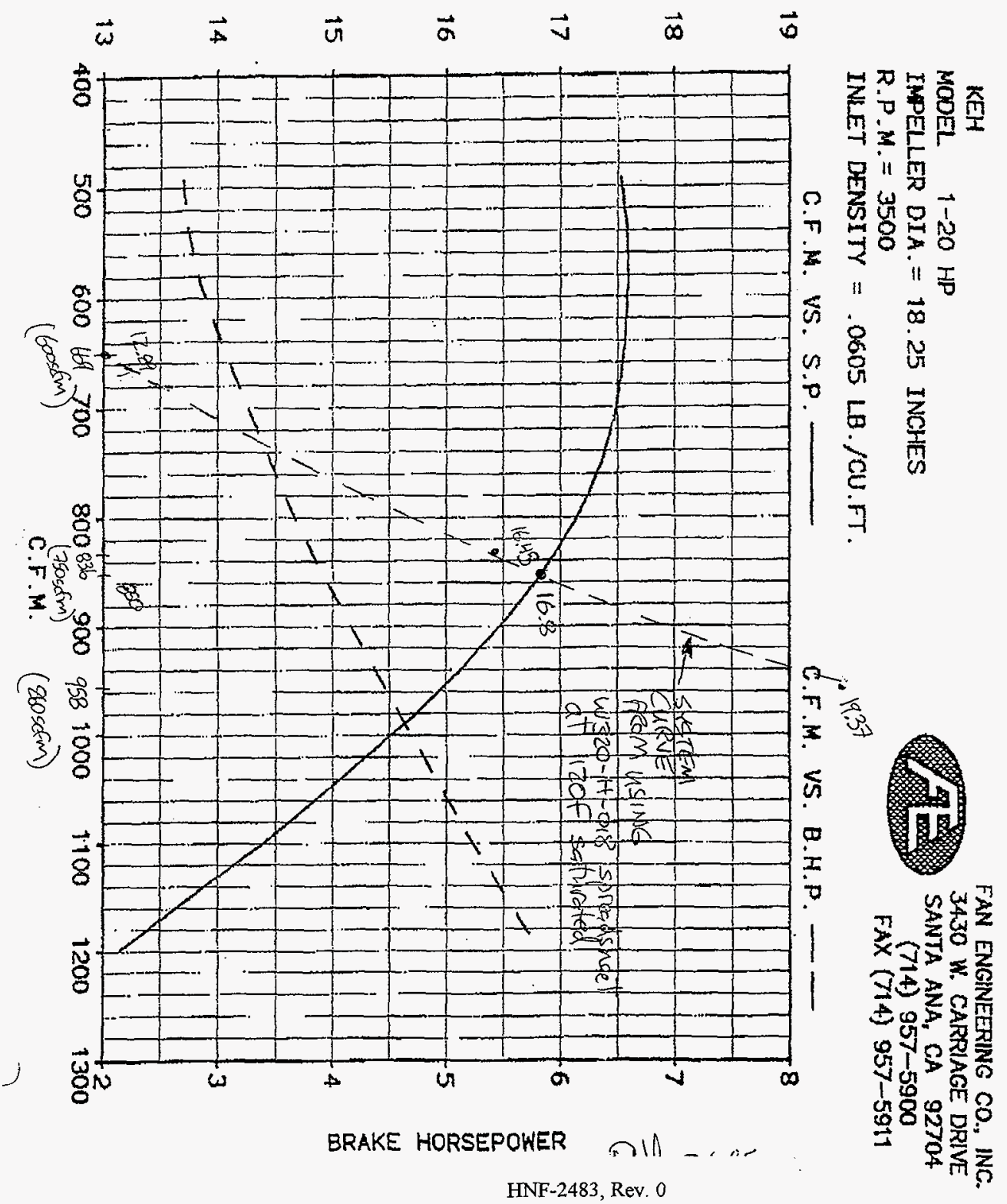


IROF UPSET ONDITONSFOR SUSTEM CURVE GENER BON

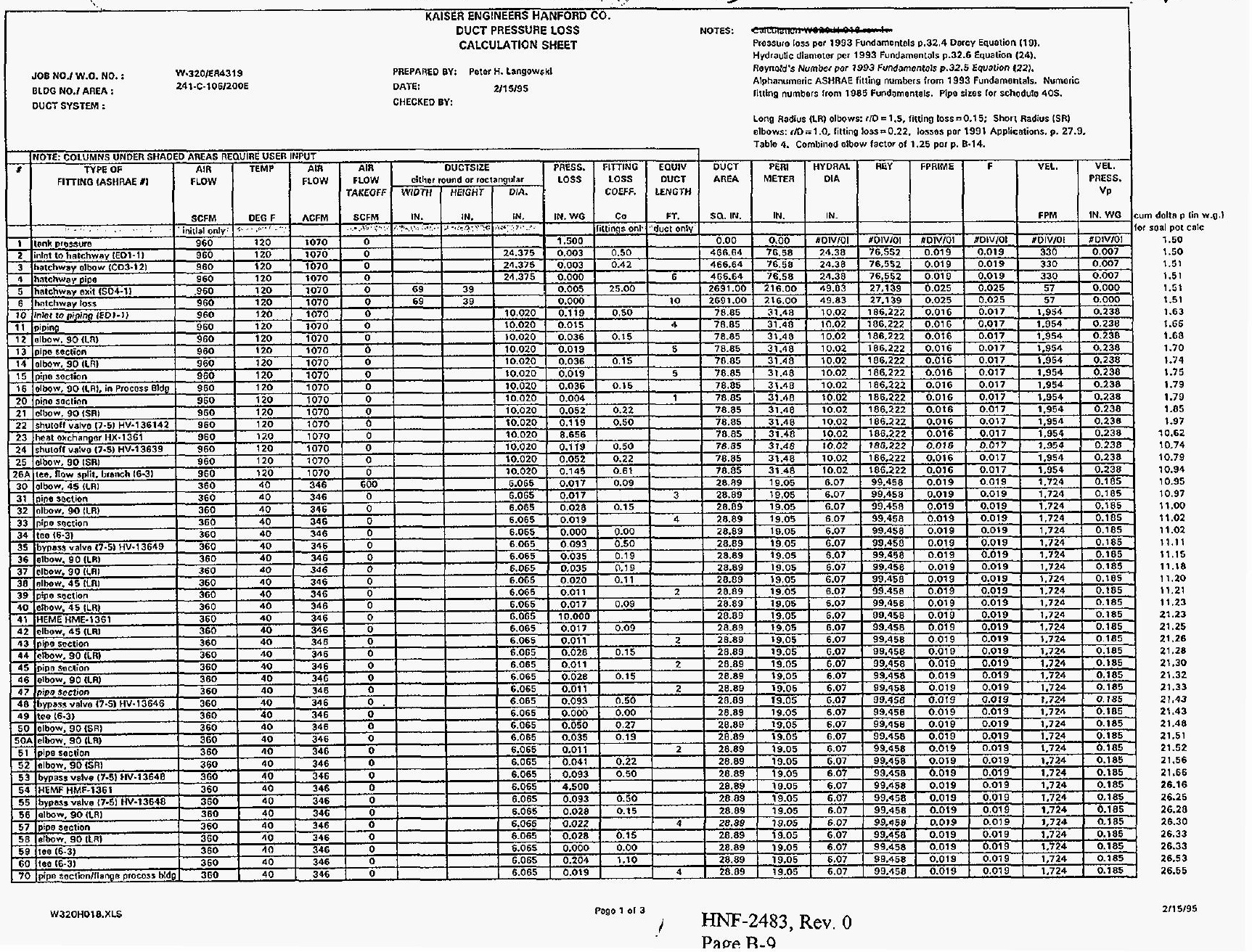




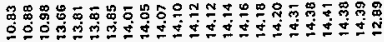

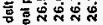

ह气

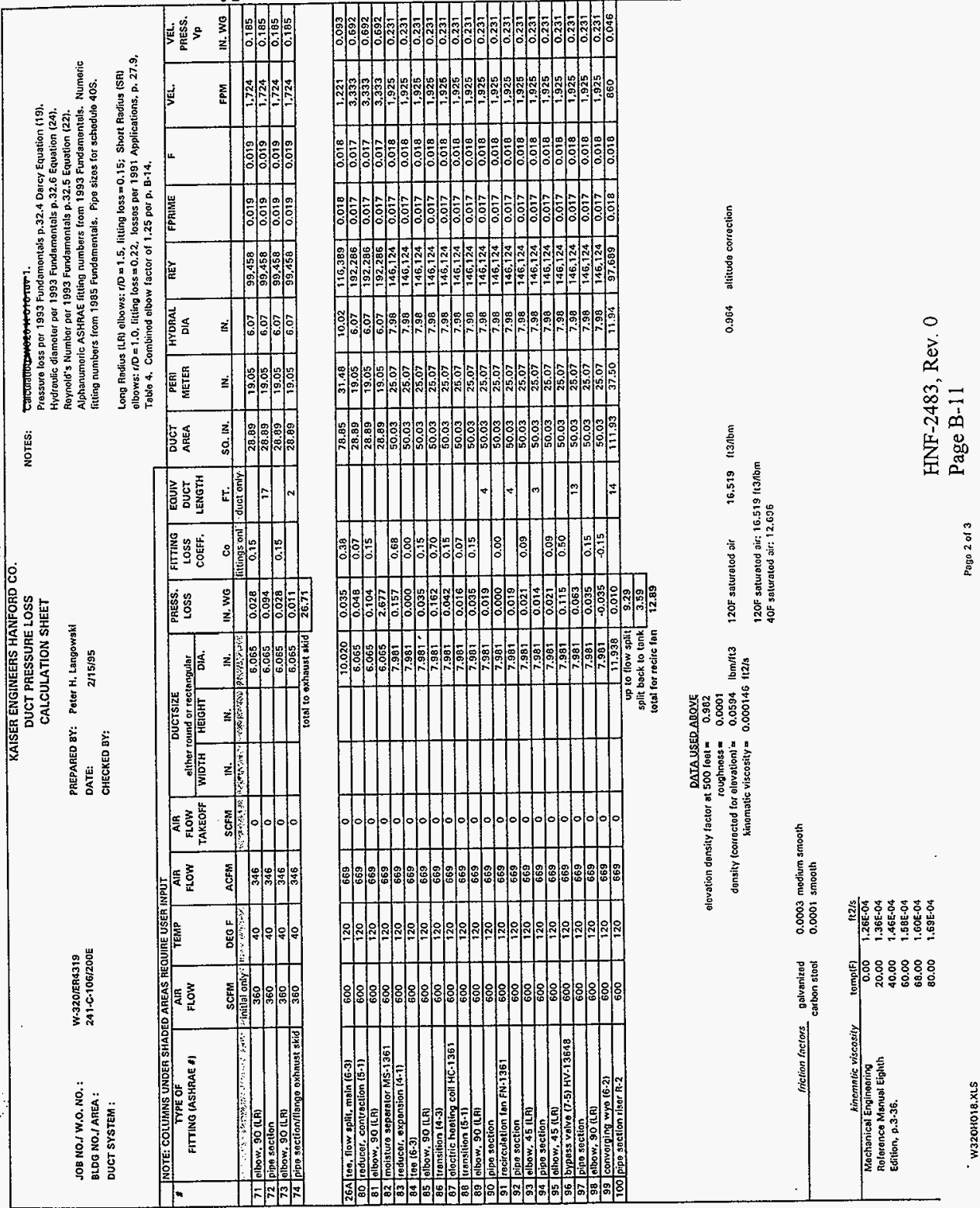


造

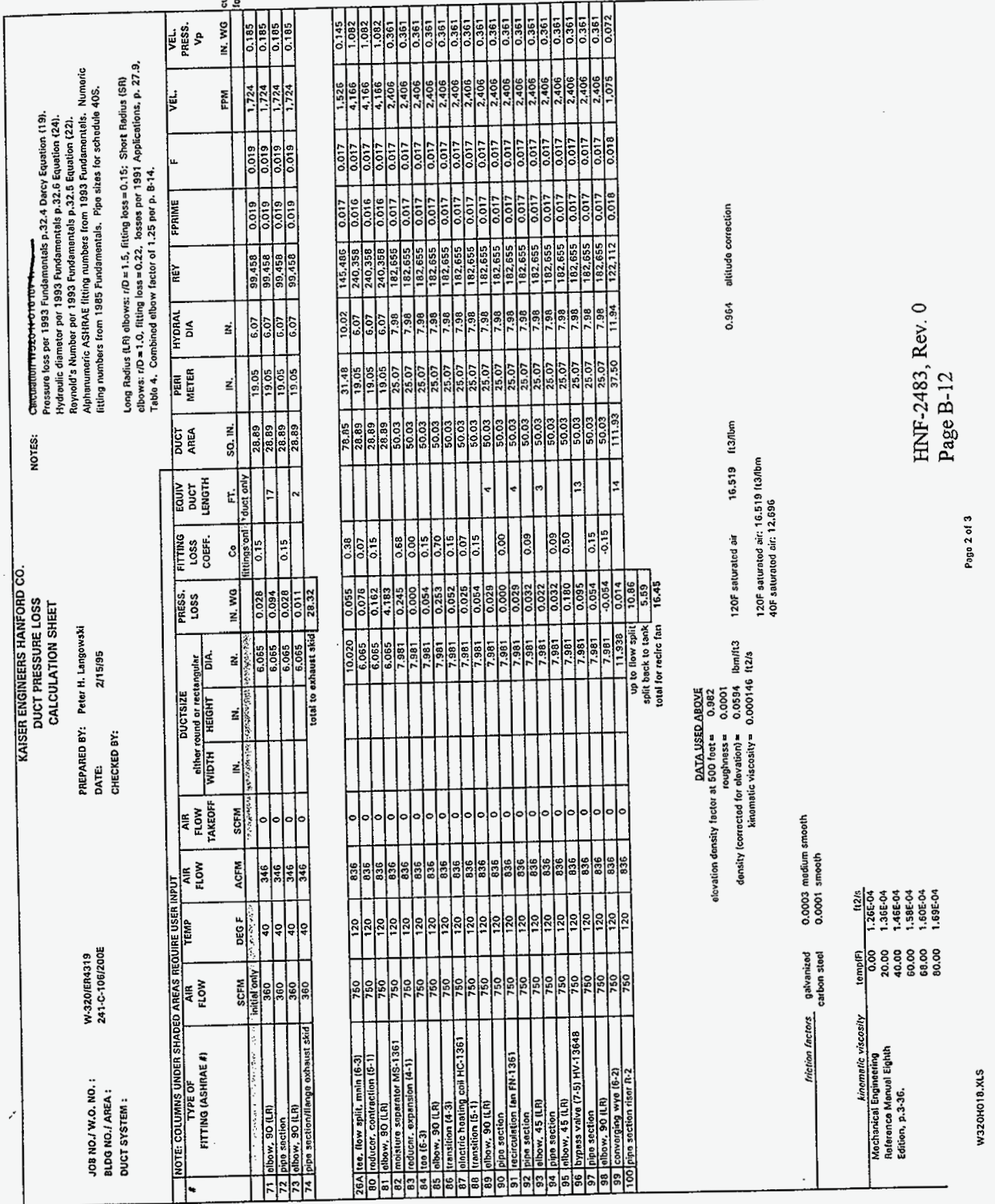




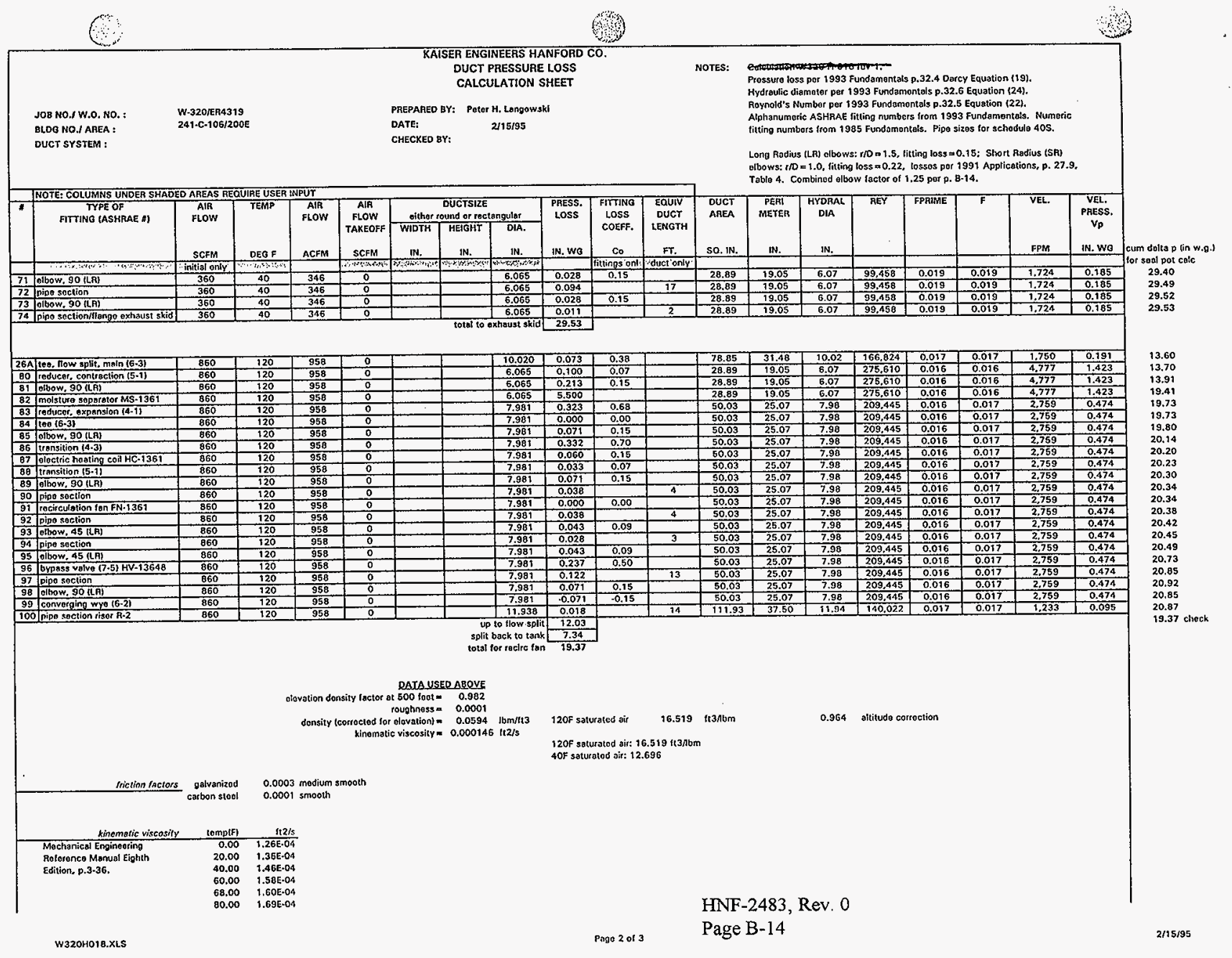


HNF-2483, Rev. 0

W320-28-004

Sizing High Efficiency Mist ETiminator

$C-i$ 
This sheet shows the status and description of the attached Design Analysis sheets.

Discipline 28/HVAC WO/Job No. ER4319

Project No. \& Name W-320 Tank 241-C-106 Waste Retrieval

Calculation ltem Sizing High Efficiency Mist Eliminator s. Calculation No. $+320=11-004$ $\omega 320-28-004$

These calculations apply to:

Dwg. No. N/A

Rev. No. N/A

Dwg. No. N/A

Rev. No. $N / A$

Other (Study, CDR)

Procurement Specification:

W-320-P5 High Efficiency Mist Eliminator Rev. No. prelimary $O$

The status of these calculations is:

[X] Preliminary Calculations

[X] Final Calculations

[] Check Calculations (On Calculation Dated)

[] Void Calculation (Reason Voided)
Incorporated in Final Drawings?
[] Yes
[X] No
This calculation veriffed by independent "check" calculations?
[] Yes
$[X]$ No

Original and Revised Calculation Approvals:

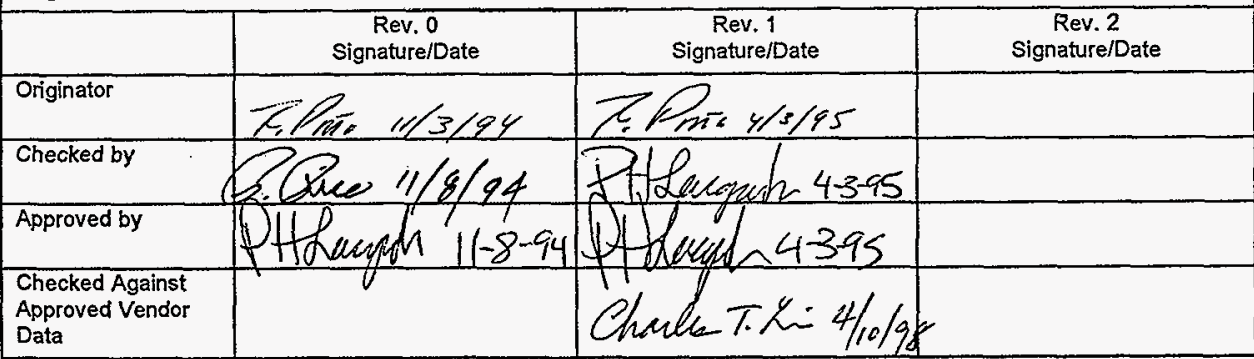

Design

Analysis

Page No.
INDEX

\section{Description}

\begin{tabular}{|l|l|}
\hline$i-i j$ & Calculation Identification and Index \\
\hline 1 & Objective, Criteria, Given Data \\
\hline 2 & Assumptions \& References \\
\hline $3-11$ & Findings, Conclusions \& Calculations \\
\hline
\end{tabular}




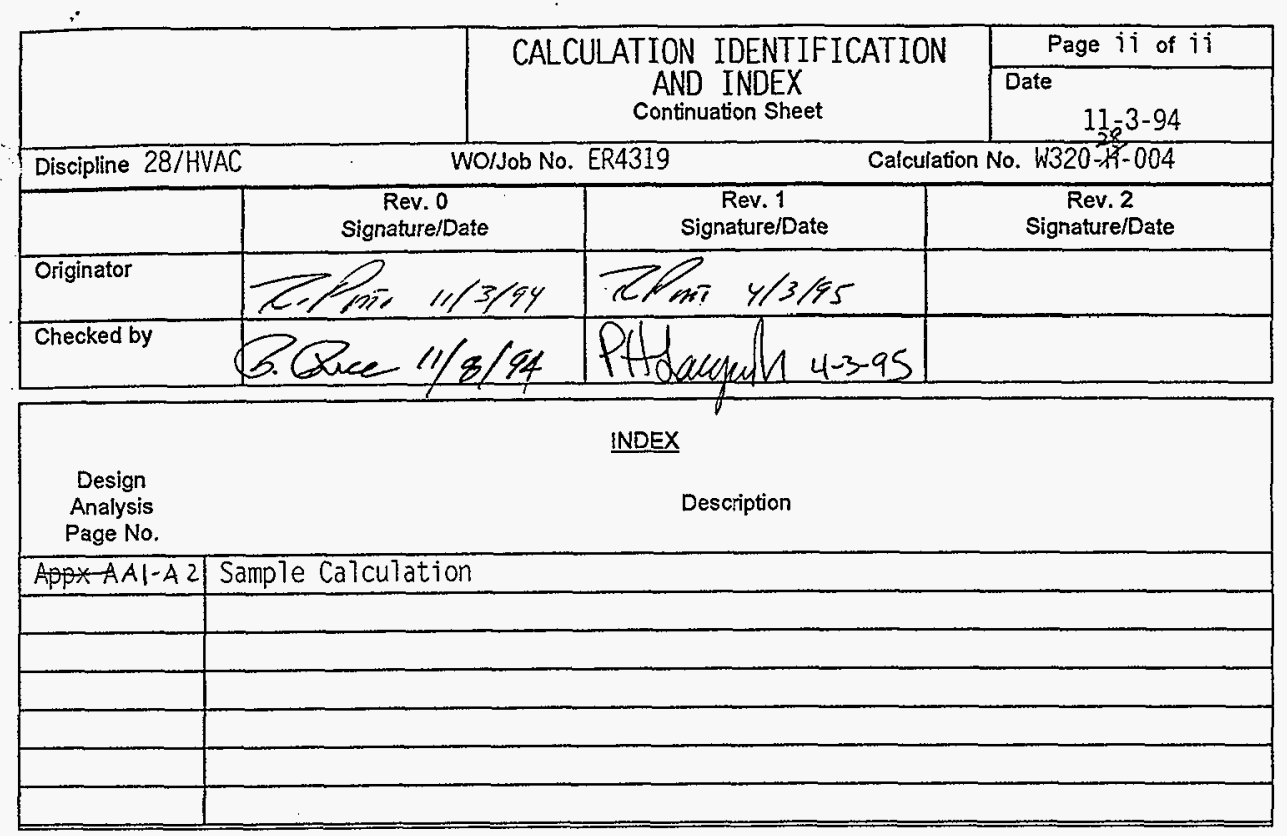

HNF-2483, Rev. 0

Page C-2 
Client WHC

Subject Sizing of High Efficiency Mist

Eliminator

Location 241-C/200 East

To size a High. Efficiency Mist Eliminator (HEME) for Project $w-320$.

\subsection{CRITERIA}

The HEME will remove aerosols and condensed water vapor (mist) from the exhaust ventilation system of Tank 241-C-106. Criteria provided per reference (1) (2), and (16).

WO/Job No. ER4319/W320

Date 11-3-94

By R. Pina

Checked $11 / 8 / 94$

By P.Rice

Revised $/ / 3 / 9$,

By Zi.Pris

3.0 GIVEN DATA

The tank airstream characterization, per Reference $(\not)$, is as follows:

AMONIA ZHE-OREANIC CONCENTRATIONS-

\begin{tabular}{|l|c|}
\hline \multicolumn{1}{|c|}{ Component } & Concentration (mg/m $\mathrm{m}^{3}$ ) \\
\hline EDTA & 0.03285 \\
\hline HEDTA & 0.02664 \\
\hline $\begin{array}{l}\text { Oxylates and formulate and } \\
\text { citrate }\end{array}$ & 0.50286 \\
\hline Ammonia & 0.00765 \\
\hline
\end{tabular}

\section{TOTAL AEROSOL CONCENTRATION \\ (<10-mi-exon) - \\ (includes components above)}

\begin{tabular}{|c|c|}
\hline Component & Concentration $\left(\mathrm{mg} / \mathrm{m}^{3}\right)$ \\
\hline Watex & $80 \quad 2.97 E+02$ \\
\hline Soluble solids in watex selution & $6.92 E-01$ \\
\hline Insoluble free solids & $1.49 E+01$ \\
\hline Total & $100-$ \\
\hline
\end{tabular}

Air Flow Rates, per Refexence (14), are as follows: Range $180-360$ scfm nominal 230 scfm 
Client WHC

\section{DESIGN ANALYSIS}

Subject Sizing of High Efficiency Mist

Eliminator

Location 241-C/200 East

WO/Job No. ER4319/W320

Date 11-3-94

Checked $11 / 8 / 97$

By R. Pina

Revised

By P Rice

By

PHR $4-395$

\subsection{ASSUMPTIONS}

Review of references, standards, etc... indicates that there is no definitive process to size/select a HEME. As will be shown later there are varied recommendations by manufacturers, test 1 abs and users of HEME's. Material fxom many sources were gathered to provide a basis for sizing and selection of a HEME for Project $W-320$. Assumptions are as stated within calculation.

\subsection{REFERENCES}

1) DOE 6430.1A, General Design Criteria

2) WHC-SD-W320-FDC-001, rev. 2, 1/18/94

3) IAEA-TELDOC-521, Retention of Iodine and other Airborne Radionuclides in Nuclear Facilities During Abnormal and Accident. Conditions, 1989

4) US Energy-Research and Development Administration 76-21, 1976

5) Perry's. Chemical Engineering Handbook, 6th Edition

6) PNL-7142, Hanford Waste Vitrification Program Pilot-Scale Ceramic Melter Test 23

7) PNL-7188, pexformance Evaluation of the Pilot-Scale, Double-Shell Tank Ventilation System Using Simulated Aerosol Streams.

8) IAEA-TELDOC-325, particulate Filtration in Nuclear Facilities, 1991

9) Industrial Ventilation, 2nd Edition

10) ASME N509-1989, Nuclear Power Plant Air Cleaning Units and Components

11) Monsanto Enviro-Chem Quote MCB-001-21390.00-000

12) $\mathrm{KOCH}$ Engineering Co. Quote 61921A00

13) CECO Filters Inc. Quote 2973-3

14) H-2-818470, HVAC Overal1 Flow Diagram, Rev. 0

15) Calculation W320-H-015, Rev. 0

16) LOI, ADDENDUM $7,12 / 13 / 94$

HNF-2483, Rev. 0

Page C-4 


\section{DESIGN ANALYSIS}

client WHC

Subject Sizing of High Efficiency Mist

Eliminator

Location 241-C/200 East
WO/Job No. ER4319/W320

Date 11-3-94

Checked $11 / 8 / 94$

Revised $4 / 3 / 45$
By R. Pina

By P. Rice

By T.Pus

\subsection{FINDINGS \& CONCIUSIONS}

The following specifications will provide a HEME suitable for the exhaust ventilation of Tank 241-C-106:

Face Velocity 12 fpm (maximum)

Nozzle Spray $.29 \pm .05 \mathrm{gpm}$ at $40 \pm 10 \mathrm{psig}$

Spraying Frequency: $1 \mathrm{~min}$./hr to provide $.29 \mathrm{gph}$

Fiber Material: Polyestex essentially $100 \%$

Removal Efficiency: $>3 \mu \mathrm{m}$ 99.99:

$$
\leq 3 \mu \mathrm{m} \quad 99.5 \%
$$

Maximum Dimensions 10'-3" $\mathrm{HT} \times 45^{\prime \prime} \mathrm{W}$

Gasket Material: EPR

Minimum Filtex Surface Area $=31 \mathrm{sq}$ ft

The mist concentration at the inlet of the HEME will be 13,049

$\mathrm{mg} / \mathrm{m}^{3}$, due to reentrained water at condenser.

\subsection{CAICULATIONS}

\section{1 FACE VELOCITY}

The removal efficiency of HEME's is dependent upon flow rate and the penetration maximum shifts towards smaller particle sizes with increased flow, per pg 56 of Ref. (3). In addition, higher face velocities have been shown to reentrain moisture. Typical HEME face velocities range from 5 to $50 \mathrm{fpm}$ per Ref. (4). Per Ref. (5), pg 18-84, the operating characteristic for a high efficiency mist eliminator range from 15 fpm to $39 \mathrm{fpm}$. Per Reference (6), pg 10.57, "the HEME should be sized for a superficial gas velocity of $10 \mathrm{fpm}$ " (in their application). A low face velocity would provide four critical HEME characteristics in any application. They are a high removal efficiency, reduced pressure drop, reduced risk of reentrainment and a greater capacity for loading. A face velocity not to exceed $12 \mathrm{fpm}$ is recommended to maximize efficiency. Note, reseaxch has indicated that HEME's have an unlimited turndown ratio; therefore, it is not necessary to specify a lower Iimit face velocity. Although HEME's are essentially designed to be regenerated by spraying the filter, some particulate loading will likely occur. The lower face velocity provides a greater filtex surface area for this likely occurrence. For example as the filter loads up the face veiocity could increase while still providing a satisfactory removal efficiency. In addition, it maintains the high removal efficiency of the HEME over its lifetime, thus minimizing the risks of filter replacement. Note, specifying a high face velocity will minimize the removal efficiency as well as decrease the life of the filter. 
Calc. No. W320- $1-004$

Revision 0

Page No. 4 of 11
Client WHC

Subject Sizing of High Efficiency Mist

Eliminator

Location 241-C/200 East

\section{DESIGN ANALYSIS}

\subsection{FILTER SURFACE AREA}

With a face velocity of $12 \mathrm{ft} / \mathrm{min}$ the required surface area is as follows:

The maximum flow shall be

Flow: $=360$

scfm

utilized to size HEME filter area.

The actual maximum

flow rate

at $40 F, 13.5 p s i a$ is:

$$
360\left(\frac{14.7}{14.7-1.2}\right) \cdot\left(\frac{460+40}{520}\right)=377
$$

Velocity: $=12$

fpm

Checked " $/ 8 / 94$

Revised

By R. Pina

By P. Rice

Surface Area

Required Min. $\frac{377}{12}=31 \quad \mathrm{ft}^{2}$

\subsection{NOZZEE SPRAY RATE}

The cases below are the best examples of water spray rates and will be used to determine the spray rate for Project $W-320$. The range of spray rates could be attributed to the different filter configurations, fiberbed packing density, manufacturer experience, flow conditions, flow rates, etc.... There are too many variables to determine why the spray rates vary so much; therefore, the most conservative option is to select a spray nozzle that can provide .086 to $10.5 \mathrm{gph}$. 
client WHC

DESIGN ANALYSIS

Subject Sizing of High Efficiency Mist

Eliminator

Location 241-C/200 East

Wo/Job No. ER4319/W320

Date $11-3-94$

By R. Pina

Checked $1 / \mathrm{g} / 94$

BypRlae

Revised

By

TABLE 1

\begin{tabular}{|c|c|c|c|c|c|}
\hline & $\begin{array}{l}\text { Savannah } \\
\text { Rivex }\end{array}$ & DWPF ${ }^{2}$ & $\mathrm{CECO}^{3}$ & PNL $^{4}$ & $\mathrm{PNI}^{5}$ \\
\hline $\begin{array}{l}\text { Spray } \\
\text { Rate } \\
\left(\mathrm{mg} / \mathrm{ft}^{3}\right)\end{array}$ & 15 & 50 & 51 & 1471 & $i_{\left(g p h / f t^{2}\right)}^{25}$ \\
\hline $\begin{array}{l}\text { Total gph } \\
\text { required } \\
\text { for W- } 320 \\
\text { using } \\
\text { above } \\
\text { rates at } \\
360 \text { scfm }\end{array}$ & .086 & .286 & .29 & 8.4 & 10.5 \\
\hline $\begin{array}{l}\text { Rate } \\
\text { Developed } \\
\text { by }\end{array}$ & in-use & in-use & experience & $\begin{array}{l}\text { scale } \\
\text { study }\end{array}$ & $\begin{array}{l}\text { scale } \\
\text { study }\end{array}$ \\
\hline
\end{tabular}

see Appx A for sample calc

1) Per discussion with D. Miller, Westinghouse Savanna, 6/29/94

2) Para. 10.2.5, Ref. (6), Defense Waste Processing Facility (DWPF) at Savannah River

3) Quote No. 2973-2, CECO Filters

4) Pg 10.53-10.54, Ref. (6)

5) Pg 2.3 , Ref. (7), note spray rate was rated per $\mathrm{ft}^{2}$ of filtex

Having determined the range of .086 to $10.5 \mathrm{gph}$ the size of the spray nozzle can now be selected. The following flow rates utilize "FullJet" spray nozzles, Spraying Systems Co. to estimate the time required to achieve the gph range. A spray nozzle of $.29 \pm .05 \mathrm{gpm}$ at $40 \pm 10 \mathrm{psig}$ provides the gph range at reasonable spray durations and provides additional capacity if required.

HNF-2483, Rev. 0

Page C-7 
Client WHC

Subject Sizing of High Efficiency Mist

Eliminator

Location 241-C/200 East
Wo/Job No. ER4319/W320

$\begin{array}{ll}\text { Date } 11-3-94 & \text { By R. Pina } \\ \text { Checked } 11 / 8 / 94 & \text { By P. Rice } \\ \text { Revised } & \text { By }\end{array}$

\begin{tabular}{|c|c|c|c|c|c|c|}
\hline & \multicolumn{5}{|c|}{ Gallons per Hour } & \multirow{3}{*}{$\begin{array}{l}\text { Maximum } \\
\text { Flow in } \\
\text { Ihr (gal) }\end{array}$} \\
\hline & .086 & .286 & .29 & 8.4 & 10.5 & \\
\hline $\begin{array}{l}\text { Nozzle at } \\
40 \mathrm{psig} \\
\text { (gpm) }\end{array}$ & \multicolumn{5}{|c|}{$\begin{array}{c}\text { Time to reach gph } \\
\text { (minutes) }\end{array}$} & \\
\hline .95 & .09 & .3 & .3 & 9 & 11 & 57 \\
\hline .5 & .17 & .6 & .6 & 17 & 21 & 30 \\
\hline .38 & .32 & .8 & .8 & 22 & 28 & 22.8 \\
\hline .29 & .29 & 1. & 1. & 29 & 36 & 17.4 \\
\hline .19 & .45 & 1.5 & 1.5 & 44.2 & 55 & 11.4 \\
\hline
\end{tabular}

see Appx A for sample calc

Note per Ref. (5), pg 18-84, "solid particulates are captured as readily as liquids in fiber beds but can rapidly plug the bed if they are insoluble." Solid particulate if not washed away from the fiberbed can become imbedded and impossible to wash off. Therefore, it is imperative that solids introduced into the HEME be minimized and spraying be done frequently to remove insolubles which have impacted the face of the fiberbed. Various studies, handbooks and manufacturers have concluded that intermittent washing of the HEME filter will remove collected aerosols and regenerate the filter (e.g., pg 6.31 of Ref. (7) and pg 37 of Ref. (8)). Findings per Ref. (3), paragraph 5.1.4, indicated "the pressure drop of the HEME filter intensively sprayed with regeneration liquid is dependent on regeneration cycles." Also manufacturers such as CECO recommend spraying intermittently.

Since the introduction of water into a contaminated stream should be minimized and frequent spraying is desired for regeneration, initially the spray should be operated at the low end providing .29 gal/hr and may be increase if necessary. Since the spray will operate for 1 min., it essentially provides .29 gpm. Note, this is significantly greater than $.035 \mathrm{gpm}$ of mist in the airstream (due to reentrained water at condenser) and should provide sufficient washing of the fiber, see paragraph 7.7 . Monitoring of the differential pressure is recommended during initial operation and the spray rate shall be adjusted, as required. In: addition, duxing any major changes in system operation (e.g, increased sluicing) the HEME should be monitored and adjusted (i.e., frequency \& duration of spray) as required. It is not recommended that the HEME operate without intermittent spraying, since this is likely to reduce the life of the HEME. 


\section{DESIGN ANALYSIS}

Client WHC

Subject Sizing of High Efficiency Mist

Eliminator

Location $241-\mathrm{C} / 200$ East
WO/Job No. ER4319/W320

Date 11-3-94

Checked $11 / 4 / 94$

Revised $4 / 3 / 95$
By R. Pina

By $P$ Rice

By ZPिम

\subsection{FIBER MATERIAI}

Recommendations from manufacturers indicate that fiberglass is not resistant to ammonia vapors and polyester is more resistant. Polyester as indicated in Table $4-1$ of Ref. (9) provides fair to excellent resistance to various chemicals (mineral acid, organic acid, alkalies, solvents \& oxidizing). Without the ability to perform tests with the actual airstream and fiberbed, the recommendations of the manufacturers and Ref. (9), Table 4-1 will be relied upon.

\subsubsection{GASKET MATERIAI}

Based on the following, EPR (EPT (NORDEL) more commonly known as EPT or EPDM or ERR) gaskets shall be used in the HEME. Compatiability charts from Aeroquip and Pall Trinity Micro Corp. indicate that EPR is compatible with ammonia. Chicago Wilcox $\mathrm{Mfg}$. Co. recommends EPR for chemicals, acids, alkalis. Klinger Inc. indicates that it is suitable for ammonia and has excellent aging properties. Grinell saunders indicates that $E P R$ has the best relative radiation resistance of their materials. Note, Viton and Buna-N were considered but eliminated due to unsatisfactory resistance to ammonia (anhydrous and aqueous) per

AEROQUIP, AIRCO and PAIL compatiability charts. Neoprene was not chosen since EPR provides bettex resistance to chemicals and radiation.

Ref. (1a) isdicates that Ammovia is Nolonger a concern; however, material will not be changed since it will perfurm satisfactorily.

\subsection{LIFE EXPECTANCY}

Essentially the HEME can be regenerated if the airstream consists mostly of soluble aerosols and minimal amounts of insoluble solid particulate.

Reference (7) attempted to predict the life of a HEME with a scale HEME; however, attempts to extrapolate this data were unsuccessful. Most references did not provide methods or estimates to predict the life of a HEME; however, I found agreement that the HEME will be regenerated with a water spray. Spraying frequently appears to be the key in extending the life of the HEME. 


\section{DESIGN ANALYSIS}

Client WHC

Subject Sizing of High Efficiency Mist

Eliminator

Location 241-C/200 East
Page No. 8 of 11

Wo/Job No. ER4319/W320

Date 11-3-94

By. R. Pina

Checked $11 / 8 / 94$

Revised

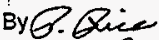

By

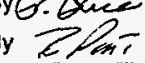

7.6 AEROSOL REMOVAL EFFICIENCY

HEME's. have varying removal efficiencies dependent upon many variables, fiber density, fiber material, flow rates, airstream, etc... The ranges listed below provide some guidance as to what we can expect. Monsanto and KOCH guarantee that their removal efficiency will be obtained and their efficiencies appear to be in close agreement with the other data. Note, other studies have demonstrated that higher efficiencies are attainable: therefore, it is within reason that manufacturer estimates are attainable. Therefore, the HEME shall be specified to satisfy a removal efficiency of all particulates $>3 \mu \mathrm{m}, 100 \%$ and $\leq 3 \mu \mathrm{m} 99.5 \%$.
essentially

The following removal efficiencies were obtained fxom studies or references :

Ref. (3) $\quad \geq 99.97 \%$

$$
\text { aerosols sizes of } 0.52 \mu \mathrm{m} \text {. }
$$

Ref. (4) $99.3 \%$

$$
0.3-0.5 \mu \mathrm{m} \text {. }
$$

Ref. (5), 5th ed., Table 18-29,

$99.3 \%$

$\leq 3 \mu \mathrm{m}$ inlet concentration of $2.12 \mathrm{mg} / \mathrm{scfm}$ of $\mathrm{H}_{2} \mathrm{SO}_{4}$.

Table 18-22, Ref (5)

$$
\begin{array}{ll}
>3 \mu \mathrm{m} & 100 \% \\
\leq 3 \mu \mathrm{m} & 95-99 \%
\end{array}
$$

Para. 5.4 of Ref. (10),

$$
\begin{aligned}
& 99 \% \\
& 5-10 \mu \mathrm{m}
\end{aligned}
$$

The following quotes are manufacturer removal efficiencies for the airstream characterization at low face velocities for project $\mathrm{W}-320$ :

III Monsanto Enviro-Chem (Ref. 11)

$$
\begin{array}{ll}
>3 \mu \mathrm{m} & 100 \% \\
\leq 3 \mu \mathrm{m} & 99.5 \%
\end{array}
$$

IV KOCH Engineering Co. (Ref. 12)

$$
\begin{array}{ll}
>3 \mu \mathrm{m} & 100 \% \\
\leq 3 \mu \mathrm{m} & 99.5 \%
\end{array}
$$

V CECO Filters Inc. (Ref. 13)

$$
\geq 0.5 \mu \mathrm{m} 99 \%
$$

\subsection{Concentration of Reentrained Condenser Water at HEME}


Client WHC

Subject Sizing of High Efficiency Mist

Eliminator

Location 241-C/200 East
Wo/Job No. ER4319/W320

Date 11-3-94

Checked $11 / 8 / 94$

Revised
By R. Pina

By R.Rie

By

The following calculation determines the amount of water mist at the inlet to the HEME due to reentrained water at the condenser. See Calc W320-H-015 for additional information.

Volumetric flowrate of reentrained water at inlet to HEWE:

$$
\begin{aligned}
& \mathrm{rth}_{\mathrm{w}}:=0.7 \cdot \frac{\mathrm{Ih}}{\mathrm{min}} \\
& \text { In lieu of repeating Ref (15), paragraph } 7.5 \\
& \text { a percentage of the mist originating from the condenser. } \\
& \mathrm{mh}_{\mathrm{r}}:=\frac{360 \cdot \frac{\mathrm{ft}^{\mathrm{J}}}{\mathrm{mtin}}}{860 \cdot \frac{\mathrm{ft}^{3}}{\mathrm{~min}}} \cdot \mathrm{mh} \\
& \mathrm{m}_{r}=0.293 \cdot \frac{\mathrm{Ih}}{\mathrm{rth}}
\end{aligned}
$$$$
\text { calc, the reentrained mist at the HEME is equal to }
$$

Concentration of reentrained water at inlet to HEME:

$$
\mathrm{m}_{\mathrm{r}} \cdot 0.454 \cdot \frac{\mathrm{kg}}{\mathrm{Ih}} \cdot \frac{1}{\mathrm{~m}} \cdot \frac{\mathrm{mux}}{\mathrm{ft}^{3}} \cdot\left(3.281 \cdot \frac{\mathrm{ft}}{\mathrm{m}}\right)^{3} \cdot 1 \cdot 10^{6} \cdot \frac{\mathrm{mg}}{\mathrm{kg}}=13052 \cdot \frac{\mathrm{mg}}{\mathrm{mL}^{3}}
$$




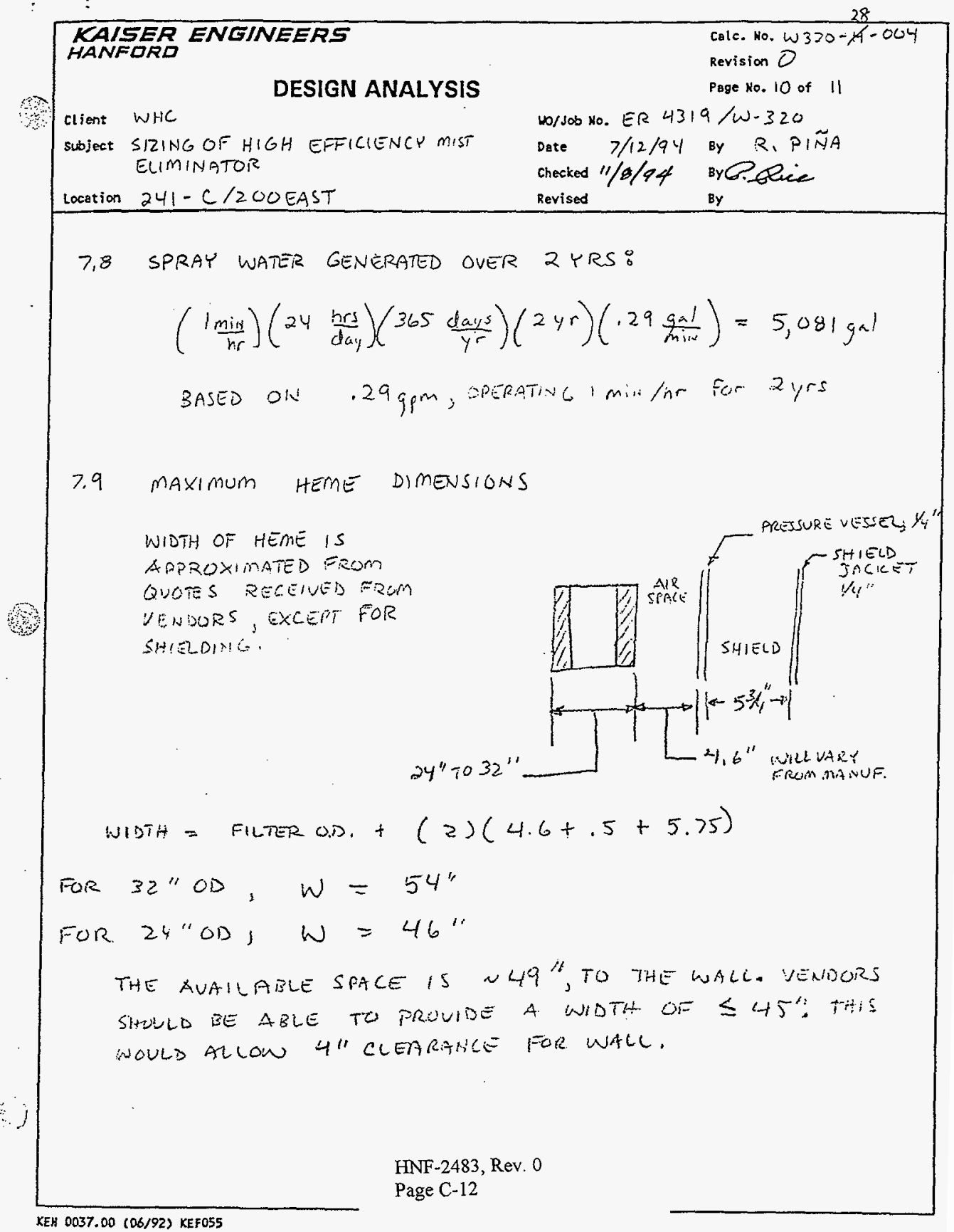




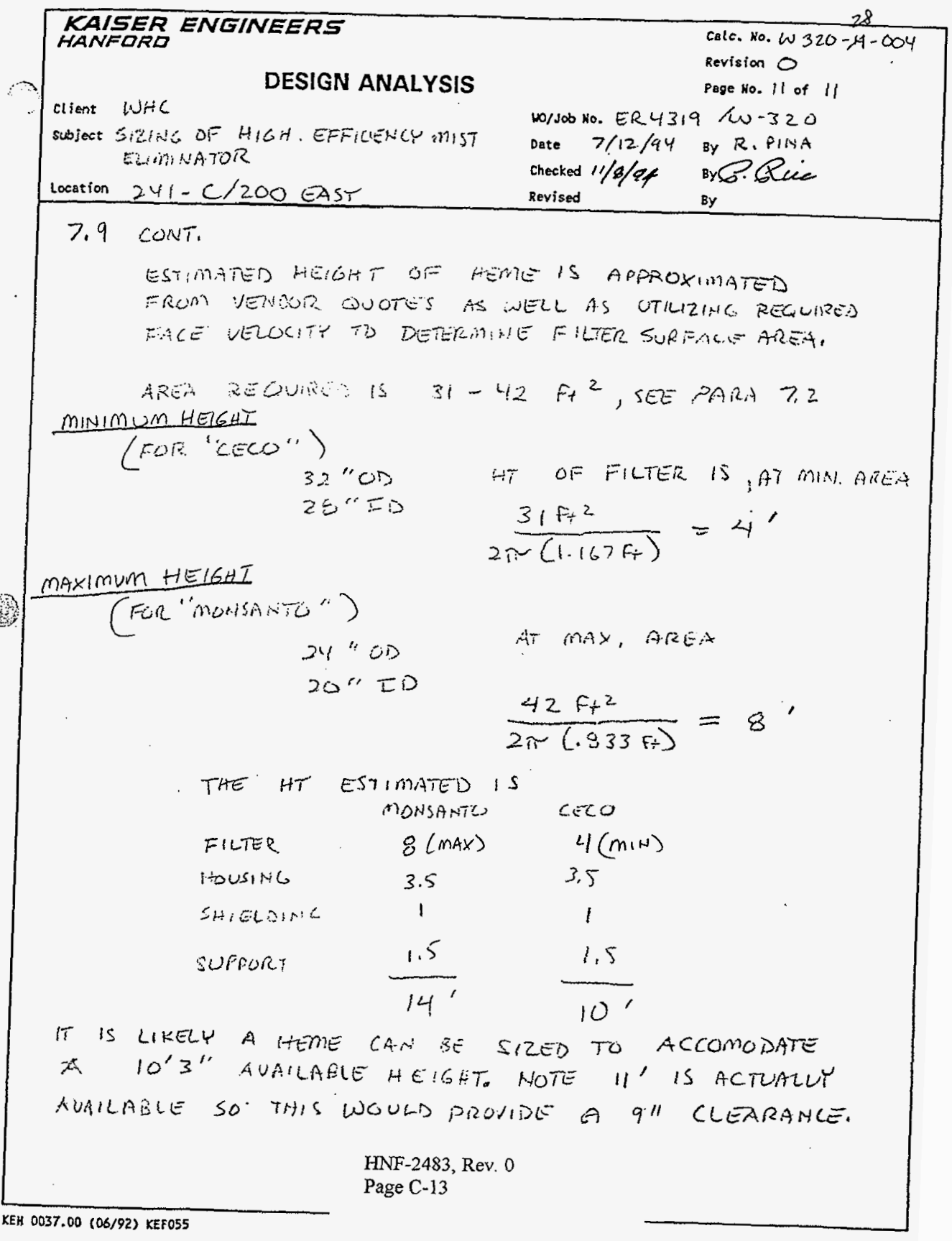


$\therefore$

KAISER ENGINEERS

DESIGN ANALYSIS

Client WH.C

SWiject SIZING OF HIGH EFFICI ENCY MIST ELIMINATOR

Location $241-C / 200$ EAST calc. ko. $w 320-\not 4-004$ Revision 0

Page No. 1 of 2

Wo/Noo No. ER4319/w-320

Date $7 / 12 / 94$ By R. PINAA

checked $11 / 8 / 94$ By G.QRice

Revised

By

APPX A

sample calc for tarle 1

THE FOLLON CALCUCATIONS CONUERT tHE RECOMMUHDED spzar pates to ing,fiz, for tagle 1.

FOR. "CECO"

THET RECOMBIENED $.37 \mathrm{gal} / \mathrm{hr}$ AT MAX $46050 \mathrm{M}$

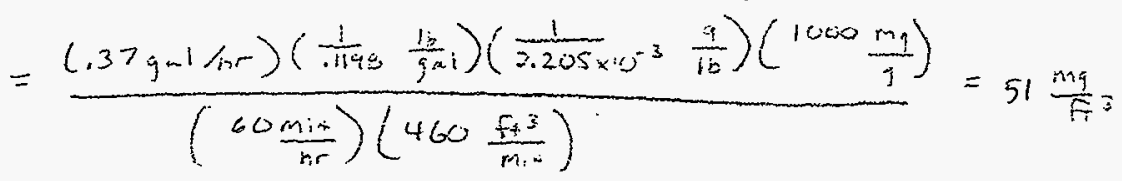

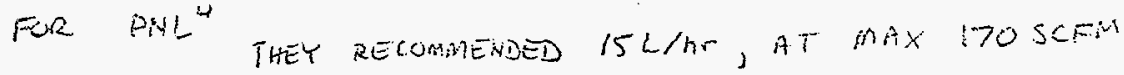

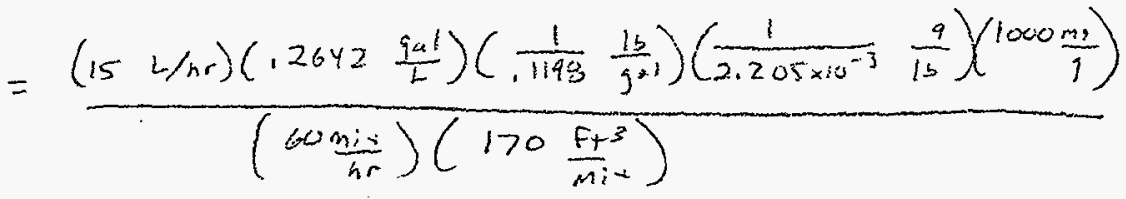

$$
\begin{aligned}
& =1471 \mathrm{mg} / \mathrm{F}_{-1}^{3}
\end{aligned}
$$

SPRAY RATES FOR SAVIANAH, DWPF $E_{i}$ PNLT NOT SHOANX SHCE THEY WERE GIVEN IN Mg/F+3,

HNF-2483, Rev, 0

Page C-14

KEH $0037.00(06 / 92)$ KEF055 
KAISER ENGINEERS

DESIGN ANALYSIS

Client WHC

subject SIZING OF HIOH EFF I CIENCF MIST RUMINATOR

location $241-C / 200$ EAST cate. No. W320-A-004

Revision 0

Page No. 2 of 2

wo/soo ko. ER 4 $319 / \omega-320$

Date $7 / 12 / 94$ By R, PINA

checked $11 / 8194$ By QR Rice

Revised

By

ThE GPH REQURED AT RECOMMEMDED SPRAY RATES AP 36OSLFM ARE DETERMINED AS FoLLOWS: (FORT TABLED

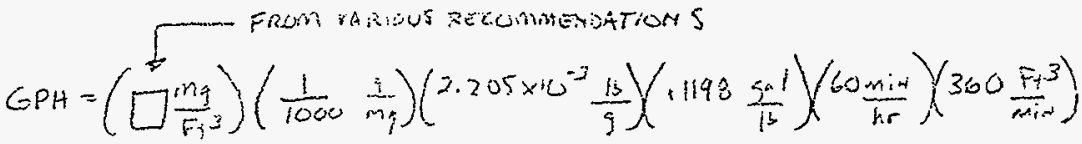

$$
\begin{aligned}
& \left.=\square \frac{m_{s}}{\mathrm{ft}^{3}}\right)\left(5,71 \times 10^{-3}\right)
\end{aligned}
$$

FOR EXAMPLE AT $51 \mathrm{my} / F \overline{3}, C E C O$

$$
6 \mathrm{pt}=51\left(5.71 \times 10^{-3}\right)=.29 \mathrm{gph}
$$

TIME fOR SPrAYiNG OBTAIHED as FULLCNS: (FOR TADLE 2)

$$
\underset{\substack{\text { spray } \\ \text { rate }}}{\rightarrow .29 \mathrm{gph}} \frac{.29 \mathrm{gpm}}{\rightarrow}=1 \text { minute per hr }
$$

TOTAL GPA. FOR PALS DETERMiNED USING MAX AREA

$$
125 \frac{\mathrm{gph}}{\mathrm{ft}^{2}}\left(4 \mathrm{Lt} \mathrm{ft}^{2}\right)=10.5 \mathrm{gph}
$$

HNF-2483, Rev. 0

Page C-15

KEN $0037.00(06 / 92)$ KEF 055 
HNF-2483, Rev, 0

W320-28-005

Sizing Electric Heating Coil

$D-i$ 
CALCULATION IDENTIFICATION AND

INDEX
Page $i$ of $i$

$5-10-94$

This sheet shows the status and description of the attached Design Analysis sheets.

Discipline HVAC

wo/Job No. ER4319

28

Project No. \& Name $W-320$ TANK 241-C-106

Calculation No. W320

$\cos 320-28-005$

Calculation item SIZING ELECTRIC HEATING COIL

These calculations apply to:

Dwg. No.

Rev. No.

Dwg. No.

Rev. No.

other (Study, CDR)

ReV. No.

The status of these calculations is:

[1 Preliminary calculations

[X] Final Calculations

[] Check Calculations (On Calculation Dated)

[] Void Calculation (Reason Voided)

Incorporated in final Drawings?

[] res [X] No

This calculation verified by independent "check" calculations? [] Yes [X] Ho

Original and Revised Calculation Approvals:

\begin{tabular}{|l|c|c|c|c|}
\hline & $\begin{array}{c}\text { Rev. } \\
\text { Signature/Date }\end{array}$ \\
\hline Originator & \\
\hline $\begin{array}{l}\text { Approved by } \\
\text { Approved Vendor Data }\end{array}$ \\
$\begin{array}{l}\text { Design Analysis } \\
\text { Page No. }\end{array}$
\end{tabular}

\begin{tabular}{|c|l|}
\hline$i$ & CALCULATION IDENTIFIC \\
\hline 1 & OBJECTIVE \\
\hline $1-2$ & CALCULATIONS \\
\hline 2 & CONCLUSIONS \\
\hline A-1 - A-5 & CataTog cut of electr \\
\hline & \\
\hline & \\
\hline & \\
\hline & \\
\hline & \\
\hline & \\
\hline & \\
\hline & \\
\hline
\end{tabular}

HNF-2483, Rev. 0

Page D-1

KEH $0378.00(06 / 92)$ KEF072 
$\Delta 1$

3

client WHC

subject SIZING ELECTRIC HEATING COIL

Location $241-C / 200 E$
DESIGN ANALYSIS
Calc. No. W320-

Revision $D$ ।

Page No. 1 of 2

OBJECTIVE: THE OBJECTIVE OF THIS CALCULATION IS TO SIZE THE ELECTRIC HEATING COIL REQUIRED FOR THE HVAC RECIRCULATION LOOP FOR PROJECT $W-320$.

CRITERIA AND SOURCE: FUNCTIONAL DESIGN CRITERIA, WHC-SD-W320-FDC-001, REVISION 2. GIVEN DATA:

- air enters COIl. at 4OFDB (DRANING H-2-818470, REV. 0)

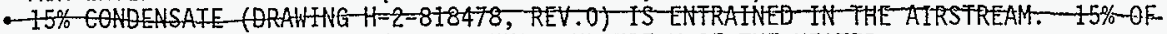
THE CONGENSATES-ENTERIAH THE- GONOEHSER UPSTTREAM-OF-THE-HEATER.

- DURING NORMAL OPERATION AIR WILL LEAVE THE COIL AT 77FDB.

(DRANING H-2-8184Z0, REV.N 0)

WO/JOb No. ER4319

Date $5-10-94$

checked

Revised

BY B. E. HURNEVICH

By 5118194 PH $46-65$ By

- Air Volume flOWING ACROSS COIL WILL BE 860 SCFM (DRAWING H-2-818470 REV. 0).

- ASSUME hEATINg COIL WILL BE SIZED TO haVE THE CAPABILITY OF hEATING AIR UP tO 10OFDB.

METHODS TO BE USED: HAND CALCULATIONS.

REFERENCES:

- ChromaloX technical P-120 CATAlog, PAge 604 \& 605.

2. ASHRAE 93' FUNDAMENTAL.

3 - CRANE FLOW OF FLUIDS (TECHNICAL PAPER N0. 410).

Y - ASHRAE POCKET GUIDE FOR HVAC. (1989)

5 - FUNDAMENTAL OF ENGINEERING THERMODYNAMICS PAGE A-57. (ROBERSON/CROWE THIRD EDITION) W320-A OOCI5, SIZING OF MOISTURE SEPARATOR, REV. I

CALCULATION:

Sensible heating:

$K W=\frac{\text { Ht } * C_{p} *(T 2-T I) * S . F .}{3412}$ (Chromalox page 604)

where:

Air VoTume $=860 \mathrm{scfm}$

Air density $=.07497 \mathrm{~b} / \mathrm{ft}^{\wedge} 3$ at $70 \mathrm{~F}$ (Ashrae Pocket Guide for HVAC, PAGE 129)

Wt - Weight of Air per hr. (Mass Flow Rate)

$W t=$ Air volume * Air density *60 min/hr

$W t=860 \mathrm{scfm} * .0749 \mathrm{Ib} / \mathrm{ft}^{\wedge} 3 * 60 \mathrm{~min} / \mathrm{hr}=3865 \mathrm{Ib}-\mathrm{air} / \mathrm{hr}$.

Cp - Specific Heat of Air $=.24$ Btu/lb at 70F (Fund. of Eng.

Thermodynamics PAGE A-57)

T2 - T1 - TEMPERATURE ACROSS COIL $=100 \mathrm{~F}-40 \mathrm{~F}=60 \mathrm{~F}$

HNF-2483, Rev. 0

Page D-2 


\section{KAISER ENGINEERS}

HANFORD

DESIGN ANALYSIS
Calc. No. W320-KF-005

Revision $\varnothing 1$

Page No, 2 of 2 client WHC

subject SIZING ELECTRIC HEATING COIL

Location $241-C / 200 E$
wo/Job No. ER4319

Date $5-10-94 \quad$ By

Revised $4 / 4 / 45$ By
BY B. E. HURNEVICH.

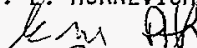

S. F. - Safety Factor $1.15(15 \%)$

$3412 \mathrm{Btu} / \mathrm{hr}$. = $1 \mathrm{KW}$

$\mathrm{KW}=\frac{3865 \mathrm{lb} \mathrm{air} / \mathrm{hr} * .24 \mathrm{Btu} / \mathrm{lb} *(100 \mathrm{~F}-40 \mathrm{~F}) * 1.15}{3412 \mathrm{Btu} / \mathrm{hr}}=18.75 \mathrm{KW}$ 36

Latent heat of Vaporization of $15 \% 1$ iquid condensate in airstream:

Entering the Condenser at $95 \mathrm{~F}$ and $100 \% \mathrm{RH}$ the Humidity Ratio(HR) $=.036757$

lb. moisture/lb.dry air (ASHRAE 93' Fundamentals Table 2 Page 6.4)

Mass Flow Rate $(W t)=$ Air Volume * Air Density * 60 min $\backslash \mathrm{hr}$.

Air Volume $=860 \mathrm{scfm}$, Air Density $=.0749 \mathrm{lb} . / \mathrm{ft} \wedge 3$

$W t=860 \mathrm{scfm} * .07491 \mathrm{~b} . / \mathrm{ft}^{\wedge} 3 * 60 \mathrm{~min} \backslash \mathrm{hr} .=3865 \mathrm{lb} / \mathrm{hr}$

Amount of $\mathrm{H} 2 \mathrm{O}$ in Airstream: Wt * HR

$\mathrm{H} 2 \mathrm{O}=3865 \mathrm{lb} / \mathrm{hr} * .036757 \mathrm{lb}$.moisture $/ \mathrm{lb}$.dry air $=142 \mathrm{lb} . \mathrm{H} 2 \mathrm{O} / \mathrm{hr}$

Exiting the Condenser at $40 \mathrm{~F}$ and $100 \%$ RH Humidity Ratio (HR) $=.005216$

1b.moisture/1b.dry air. (ASHRAE 93' Fundamentals Table 2 Page 6.3)

Amount of $\mathrm{H} 20$ in airstream exiting condenser: $3865 \mathrm{~Tb} / \mathrm{hr} * .005216$

lb.moisture/1b.dryair $=20.2 \mathrm{lb} / \mathrm{hr}$

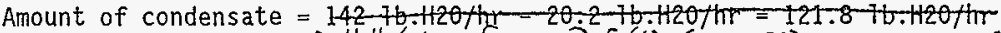

$0.11 \mathrm{lb} / \mathrm{m}$. N From Ref.(6), $(7-.59)$, REPRESENTS $36 \%$ REEMTLAHMEMT

$15 \%-18.3-76.1420 / \mathrm{tr}$

6.6

Heat of Vaporization of $18 .-3 \mathrm{ib} . \mathrm{H} 20 / \mathrm{hr}$ of condensate:

Latent Heat of Evaporization of $\mathrm{H} 20$ at $.2 \mathrm{psig}$ and $53 \mathrm{~F}=1053 \mathrm{Btu} / \mathrm{lb}$. (Crane Flow of

Fluids page A-12)

BTU $=\underset{18.5}{18.3} \mathrm{lb} . \mathrm{H} 20 / \mathrm{hr} * 1053 \mathrm{Btu} / 1 \mathrm{~b}=\frac{6950}{2.0270} \mathrm{btu} / \mathrm{hr}$

$\mathrm{KW}=\frac{18270 \mathrm{btu} / \mathrm{hr}}{3412}=5.7 \mathrm{KH}$

3412

$2.0 \quad 20.75$

TOTAL POWER REQUIRED ELECTRIC HEATING COIL $=18.75 \mathrm{KH}+5.7 \mathrm{KH}=24.45 \mathrm{KH}$

CONCLUSION: An additional 15\% safety factor was included in the sizing of this heating coil along with the heating coil having the capability of heating air up to 100FDB. With the presence of $35 \% 1$ iquid condensate in the airstream an additiona $725.7 \mathrm{KW}$ of power is needed to evaporate the condensate. The total power required to heat the airstream to the specified design conditions is $24.45 \mathrm{KW}$, therefore a $30 \mathrm{KW}$ heating coit has been selected. The heating coil is slightly ovetsized to provide additional capacity Forcoil element Fajlure. If a Fen coil a fail, immediate replacement is not required to maintain the required lood. elements 
ifil 3 Process air heaters $\quad \begin{array}{cc}A-1 \\ \text { Chromalox }\end{array}$

BEST: $V$ NILABLE COPY

igh temperature air duct heaters

HNF-2483, Rev. 0

Page D-4

ne if $300 \mathrm{~kW}$ and above

minc yilet air temperatures

g. $1200^{\circ} \mathrm{F}$

to volt 3 phase (voltages to b $\mathrm{V}$ available)

th .475 dia. tubular

ements

pes ADH and ADHT

\section{olications}

Hezling air for various orying/curing erations up to $1200^{\circ} \mathrm{F}$ air temperature

* Heal treeting

Fetrealing or dehumioification oher similar air heating applications

$\mathrm{Ac}$

axarures

yeged construction. Siurdy 0.475 oi7 - Feier iubular elements mounted to a f timinal housing made of $18 \mathrm{ca}$. Wuninized sieel. Element support

2. ss of 16 ga. aluminized steel are

J in place by siainless sleel support

s. High temperalure units have the

Litional íeature of stainless sleel

y thetial for the 3 inch insulation hous.

终 end element support plate - all of

trich provices superior rigidity,

Ferith and reliability.

fong life metal sheath tubular

itments-Corroslonloxldation

Histant sheath. High grade

roloy: sheath material for excellent

- rosion/oxidation resistance at high

perating iemperafures.

\&h purity magnesium oxide. The

zimerits are filled with highest purity

snds of magnesium oxide refraciory

YGO compacted to a rock hard den-

fo insure maximum thermal conduc-

finy and electrical insulation resistance.

kerior grade resistance wire. The

tert of each tieating element is made

I $50 \%$ nickel. $2.0 \%$ chromium resistance

te tor meximum long life.

Lix watt density resistor wire. Watt

Ensity on the healing coil is designed

\& bw watl density operation by in-

-ising the coil diameler, gauge and

Sh of resistance wire to give maxi-

$\rightarrow$ surface area and low operating

ins ace temperalure - providing

st coil life.
ADH-Low/medium temperalure $(30$ w/in 2$)$

( $800^{\circ} \mathrm{F}$ maximum oulput air temperature)

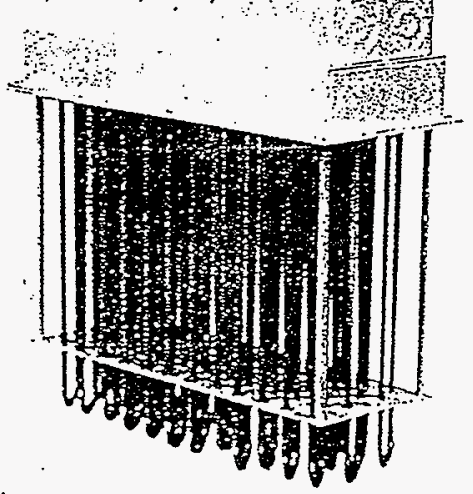

Duct opening is

$0+1 / 4^{*} \times H+1 / 4^{*}$

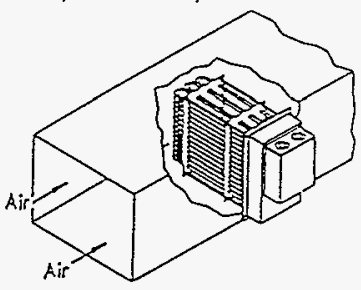

Typicol insiollotion

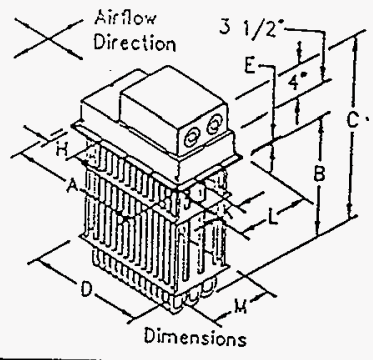

Dirimensions

ADK-Low/medlum temperature (30 w/in' $\left.{ }^{2}\right)$

\begin{tabular}{|c|c|c|c|c|c|c|c|c|c|c|c|c|c|c|c|}
\hline \multirow[b]{2}{*}{$\mathrm{kw}$} & \multicolumn{9}{|c|}{ Dimensions-Inches } & \multirow{2}{*}{$\begin{array}{l}\text { Ho. } \\
\text { Elem. }\end{array}$} & \multirow{2}{*}{$\begin{array}{l}\text { Ho. } \\
\text { tire. }\end{array}$} & \multirow{2}{*}{$\begin{array}{l}\text { Crtalog } \\
\text { Ho. }\end{array}$} & \multirow[b]{2}{*}{$\begin{array}{l}52 \\
b=\end{array}$} & \multirow[b]{2}{*}{$\operatorname{mx}$} & \multirow[b]{2}{*}{ Wh. } \\
\hline & $A$ & B & C & $D$ & $E$ & $k$ & $\mathrm{~K}$ & $\mathrm{~L}$ & $M$ & & & & & & \\
\hline $\begin{array}{l}5 \\
10 \\
15 \\
\end{array}$ & $\begin{array}{l}5 s / 4 \\
73 / 4 \\
934 \\
\end{array}$ & $\begin{array}{l}201 / 4 \\
20 \% \\
20 \% \\
\end{array}$ & $\begin{array}{r}28 \% / \\
28 \% \\
28 \% \\
\end{array}$ & $\begin{array}{l}4 \\
6 \\
8 \\
\end{array}$ & $\begin{array}{l}1 / 4 \\
1 / 4 \\
1 / 4 \\
\end{array}$ & $\begin{array}{l}21 / 2 \\
3^{1 / 2} \\
3 \\
\end{array}$ & $\begin{array}{l}31 / 2 \\
31 / 2 \\
3 \% \\
\end{array}$ & $\begin{array}{l}111 / 6 \\
111 / 6 \\
111 / 6 \\
\end{array}$ & $\begin{array}{l}9 / / 2 \\
9: / 2 \\
9: / 2\end{array}$ & $\begin{array}{l}3 \\
6 \\
9 \\
\end{array}$ & $\begin{array}{l}i \\
i\end{array}$ & $\begin{array}{l}\text { ADH-CS5 } \\
\text { ADH-Oi0 } \\
\text { ADH-Oi5 }\end{array}$ & $\begin{array}{l}5 \\
5 \\
5 \\
\end{array}$ & $\begin{array}{l}210016 \\
210024 \\
210002\end{array}$ & $\begin{array}{l}8 \\
15 \\
25\end{array}$ \\
\hline $\begin{array}{l}20 \\
25 \\
30 \\
\end{array}$ & $\begin{array}{l}11 \% \\
135 \% \\
15 \% \\
\end{array}$ & $\begin{array}{l}20 \% \\
20 \% \\
20 \% \\
\end{array}$ & $\begin{array}{l}281 / 4 \\
281 / 4 \\
281 / 4 \\
\end{array}$ & $\begin{array}{l}10 \\
12 \\
14 \\
\end{array}$ & $\begin{array}{l}1 / 4 \\
1 / 4 \\
3 / 6 \\
\end{array}$ & $\begin{array}{l}23 / 4 \\
31 / 4 \\
31 / 4 \\
\end{array}$ & $\begin{array}{l}31 / 2 \\
31 / 2 \\
31 / 2 \\
\end{array}$ & $\begin{array}{l}113 / 4 \\
111 \% \\
11 \% \\
\end{array}$ & $\begin{array}{l}91 / 2 \\
91 / 2 \\
91 / 2 \\
\end{array}$ & $\begin{array}{l}12 \\
15 \\
18 \\
\end{array}$ & $\begin{array}{l}1 \\
1 \\
1\end{array}$ & $\begin{array}{l}\text { ADU-OS } \\
\text { LDH-OSS } \\
\text { LDH-NOS }\end{array}$ & $\begin{array}{l}5 \\
5 \\
5 \\
\end{array}$ & $\begin{array}{l}21000 \\
21009 \\
2,000\end{array}$ & $\begin{array}{l}35 \\
40 \\
55\end{array}$ \\
\hline $\begin{array}{l}35 \\
40 \\
45 \\
\end{array}$ & $\begin{array}{l}175 / 4 \\
193 / 5 \\
215 \% \\
\end{array}$ & $\begin{array}{l}20 \% / \\
20 \% \\
20 . / 2 \\
\end{array}$ & $\begin{array}{l}28 \% \\
28 \% \\
28 \% \\
\end{array}$ & $\begin{array}{l}16 \\
18 \\
20 \\
\end{array}$ & $\begin{array}{l}3 / 4 \\
3 / 2 \\
3 / 4 \\
\end{array}$ & $\begin{array}{l}4 \% / 4 \\
4 \% \\
5 \% \\
\end{array}$ & $\begin{array}{l}3^{1 / 2} \\
3^{1 / 2} \\
3^{1 / 2} \\
\end{array}$ & $\begin{array}{l}111 / 4 \\
11 \frac{1}{4} \\
11 \frac{1}{6}\end{array}$ & $\begin{array}{l}2 \% / 2 \\
9 \% / 2 \\
9 \% / 2 \\
\end{array}$ & $\begin{array}{l}21 \\
24 \\
27 \\
\end{array}$ & $\begin{array}{l}1 \\
2 \\
2 \\
\end{array}$ & $\begin{array}{l}\text { ADHOS } \\
\text { ADHOS } \\
\text { ADH } 205\end{array}$ & $\begin{array}{l}5 \\
5 \\
5 \\
\end{array}$ & $\begin{array}{l}27005 \\
20003 \\
20091\end{array}$ & $\begin{array}{l}65 \\
70 \\
80\end{array}$ \\
\hline $\begin{array}{l}50 \\
60 \\
80 \\
\end{array}$ & $\begin{array}{l}235 \% \\
275 \% \\
35 \% \\
\end{array}$ & $\begin{array}{l}203 \\
2035 \\
20 \% \\
\end{array}$ & $\begin{array}{l}28 \% \\
28 \% \\
28 \% \\
\end{array}$ & $\begin{array}{l}22 \\
25 \\
34 \\
\end{array}$ & $\begin{array}{l}3 / 4 \\
3 / 4 \\
34\end{array}$ & $\begin{array}{l}5 \% / 2 \\
41 / 2 \\
43 / 2\end{array}$ & $\begin{array}{l}31 / 2 \\
31 / 2 \\
31 / 2 \\
31 / 4\end{array}$ & $\begin{array}{l}11 \% \\
11 \% / 6 \\
11 \% \\
\end{array}$ & $\begin{array}{l}91 / 2 \\
91 / 2 \\
9 \% \\
91 / 2\end{array}$ & $\begin{array}{l}30 \\
36 \\
48 \\
\end{array}$ & $\begin{array}{l}2 \\
? \\
4 \\
\end{array}$ & $\begin{array}{l}A D H-C 50 \\
+D H+60 \\
D D H\end{array}$ & $\begin{array}{l}5 \\
5 \\
15 \\
\end{array}$ & $\begin{array}{l}2,00 \\
2010 \\
2 x+0\end{array}$ & $\begin{array}{l}90 \\
105 \\
140\end{array}$ \\
\hline $\begin{array}{l}90 \\
100 \\
144\end{array}$ & $\begin{array}{l}39 \% \\
43 \% \\
35 \% \\
\end{array}$ & $\begin{array}{l}204 \\
20 \% \\
35 \\
\end{array}$ & $\begin{array}{l}281 / 4 \\
281 / 2 \\
42 \% \\
\end{array}$ & $\begin{array}{l}38 \\
42 \\
34 \\
\end{array}$ & $\begin{array}{l}2 / 4 \\
3 \% \\
3\end{array}$ & $\begin{array}{l}4 \% \\
5 \% / \\
43 \% \\
\end{array}$ & $\begin{array}{l}3 \% / 2 \\
3 \% \\
3 \% \\
\end{array}$ & $\begin{array}{l}11 \% / 4 \\
11 \% \\
11 \% \\
11 \%\end{array}$ & $\begin{array}{l}91 / 2 \\
91 / 2 \\
91 / 2 \\
\end{array}$ & $\begin{array}{l}54 \\
60 \\
48 \\
\end{array}$ & $\begin{array}{l}5 \\
5 \\
-5\end{array}$ & 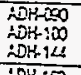 & $\begin{array}{l}\mathrm{kS} \\
5 \\
\mathrm{kS}\end{array}$ & $\begin{array}{l}2 x 029 \\
2 \pi 09 \\
2 x=0\end{array}$ & $\begin{array}{l}160 \\
175 \\
165\end{array}$ \\
\hline $\begin{array}{l}162 \\
216\end{array}$ & $\begin{array}{l}395 / 4 \\
275 \% \\
33 \%\end{array}$ & $\begin{array}{l}35 \\
35 \\
35\end{array}$ & $\begin{array}{l}42 \% \\
42 \% \\
42 \%\end{array}$ & $\begin{array}{l}38 \\
26 \\
32\end{array}$ & $\begin{array}{l}y / 6 \\
3 / 6 \\
y / 6\end{array}$ & $\begin{array}{l}4 \% / 2 \\
41 / 2 \\
51 / 2\end{array}$ & $\begin{array}{l}31 / 2 \\
3 \% \\
3 \%\end{array}$ & $\begin{array}{l}111 / 4 \\
20 \\
20\end{array}$ & $\begin{array}{l}91 / 2 \\
18 \% / 2 \\
18 \% / 6\end{array}$ & $\begin{array}{l}54 \\
72 \\
90 \\
\end{array}$ & $\begin{array}{l}5 \\
5 \\
5 \\
\end{array}$ & 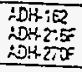 & $\begin{array}{l}5 \\
5 \\
5\end{array}$ & $\begin{array}{l}2 \pi 63 \\
2 \pi 71 \\
27=\infty\end{array}$ & $\begin{array}{l}125 \\
240 \\
300\end{array}$ \\
\hline
\end{tabular}




\section{High temperature air duct heaters (con't.)}

Supertor performance at element bends. All elemenis bends are repressed in hyoraulic presses atter bending to assure recompaction of refractory material to eliminate hot spois and electrical insuletion voios.

Sturdy metal sheath elements elim!. nate problems associated with open coll resistance wire units. Such es high operaling temperatures resulting in shorer life, short circuits due to broken resistance wite or insulaiors, electrical shock hazard and flash fire hazard on start up due to dust and dir accumu. lation.

Easy element replacement. Incividual elements are mechanically lasiened io the flange permiting convenient, easy replacement.

Low wiring compartment temperatures. Made possible by the addition of a one inch thick blanket of insulation in the ierminal box-allows use of low temperaiure tield wiring instead of expensive high iemperature busbars and wire. High iemperalure units include additional three inches of insulation to help reduce duct heat losses.

Moets NEC wiring requirements. Heaters are subdivided into $48 \mathrm{amp}$ maximum circuits in compliance with the National Elecirical Code (NEC).

Easy access to simplifted fleld wir. ing terminals. Terminal housing is completely removable for maximum access to field wiring terminals. Individual terminal blocks with threaded siud type terminals are proviced for each circuit to permit quick positive attachment of circuit wiring conduciors.

Dirtdust resistant terminal housing. Terminal housing made of solid heavy gauge aluminized steel rather than perlorated melal to resist dirt and dust accumulation on the electrical connections and thus provide longer service life.

Flange mounting gasket. Packed separately with each duct heater $10 \mathrm{~min}$ imize air leakage beiween the liange and air duct.

HNF-2483, Rev. 0 Page D-5
ADHT-High lempetalure (20 w/in.;)

(1200\% F maximum outpul air temperaluie)

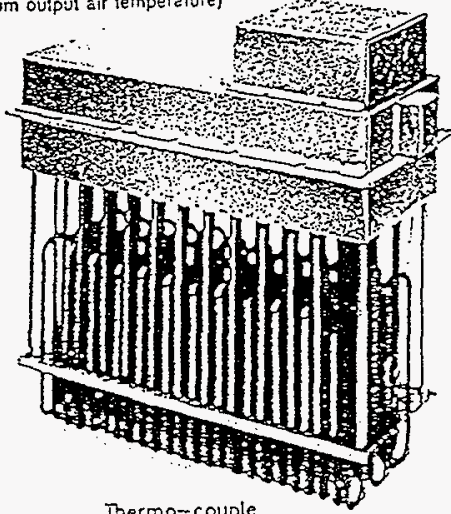

Thermo-couple

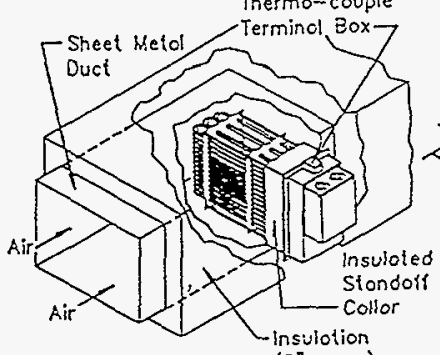

Typicol Instollotion

(3" mox.)

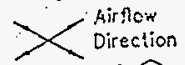

$35 / 8^{\circ}$

$31 / 2$

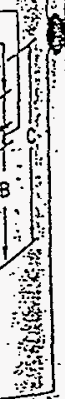

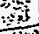

ADHT-Kigh temperature $\left(20 \mathrm{w} / \mathrm{in}^{2}\right)$

Dimensions-Inches

\begin{tabular}{|c|c|c|c|c|c|c|c|c|c|c|c|c|c|c|}
\hline & & SOA & -1 & & & & & & & & & & & \\
\hline $\mathrm{kHH}$ & $A$ & 8 & C & $\bar{D}$ & $E$ & 8 & $\bar{K}$ & $i$ & $M$ & Elem. & Cift. & no. & I05 & $\mathrm{PCA}-10$ \\
\hline $\begin{array}{l}5 \\
10 \\
15 \\
\end{array}$ & $\begin{array}{l}5 s / 2 \\
7 s / 2 \\
0 s / 4\end{array}$ & $\begin{array}{l}20 \% / 2 \\
203 / 2 \\
203 / 4\end{array}$ & $\begin{array}{l}28 \% / 4 \\
25 \% \\
28 \%\end{array}$ & $\begin{array}{l}4 \\
6 \\
8\end{array}$ & $\begin{array}{l}1 / 2 \\
1 / 4 \\
y\end{array}$ & $\begin{array}{l}21 / 2 \\
316 \\
3\end{array}$ & $\begin{array}{l}312 \\
32 \% \\
31 \% \\
\end{array}$ & $\begin{array}{l}91 \% / 6 \\
911 / 6 \\
11 \% / 8\end{array}$ & $\begin{array}{l}8^{3 / 2} \\
0^{1 / 2} \\
9 \% 2\end{array}$ & $\begin{array}{l}3 \\
5 \\
3 \\
\end{array}$ & $\begin{array}{l}1 \\
1 \\
1\end{array}$ & $\begin{array}{l}\text { ADHT.035 } \\
\text { ADHT.010 } \\
\text { ADHT.015 } \\
\end{array}$ & $\begin{array}{l}\text { N } \\
\text { NS } \\
\text { NS } \\
\end{array}$ & 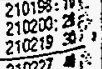 \\
\hline $\begin{array}{l}20 \\
25 \\
30 \\
\end{array}$ & $\begin{array}{l}115 / 2 \\
135 / 2 \\
15 \% / 2\end{array}$ & $\begin{array}{l}203 / 4 \\
203 \% \\
203 \%\end{array}$ & $\begin{array}{l}28 \% \\
25 \% \\
28 \% \\
\end{array}$ & $\begin{array}{l}10 \\
12 \\
14 \\
\end{array}$ & $\begin{array}{l}1 / 4 \\
1 / 4 \\
3 / 4\end{array}$ & $\begin{array}{l}2^{2 \%} \\
3 \% \\
3^{3}, 4\end{array}$ & $\begin{array}{l}31 \% \\
312 \\
3 \div 2 \\
\end{array}$ & $\begin{array}{l}91 \% / 6 \\
19 \% / 6 \\
11 \%\end{array}$ & $\begin{array}{l}91 / 2 \\
9 \% 2 \\
9 \%\end{array}$ & $\begin{array}{l}12 \\
15 \\
18 \\
\end{array}$ & $\begin{array}{l}1 \\
1 \\
1\end{array}$ & $\begin{array}{l}\text { AORT.020 } \\
\text { ROKT-025 } \\
\text { ROKT-030 }\end{array}$ & $\begin{array}{l} \\
\text { NS } \\
\text { NS } \\
\end{array}$ & $\begin{array}{l}210227 \\
210235 \\
210043\end{array}$ \\
\hline $\begin{array}{l}35 \\
40 \\
45 \\
\end{array}$ & $\begin{array}{l}173 / 2 \\
105 / 2 \\
213 / 4\end{array}$ & $\begin{array}{l}203 \% \\
20 \% \\
20 \%\end{array}$ & $\begin{array}{l}28 \% \\
28 \% \\
281 / 4\end{array}$ & $\begin{array}{l}16 \\
18 \\
20 \\
\end{array}$ & $\begin{array}{l}3 / 4 \\
3 / 4 \\
3\end{array}$ & $\begin{array}{l}4 \% \\
62: 4 \\
53: 6\end{array}$ & $\begin{array}{l}31 / 2 \\
31 / 2 \\
31 / 2 \\
\end{array}$ & $\begin{array}{l}11 \% \\
11 \% / 8 \\
11 \%\end{array}$ & $\begin{array}{l}9: 2 \\
9 \% \\
9 \%\end{array}$ & $\begin{array}{l}21 \\
24 \\
27 \\
\end{array}$ & $\begin{array}{l}1 \\
2 \\
2 \\
\end{array}$ & $\begin{array}{l}\text { ADHT.035 } \\
\text { AOHT-040 } \\
\text { ADHT.045 }\end{array}$ & $\begin{array}{l}\text { NS } \\
\text { S } \\
\text { NS }\end{array}$ & $\begin{array}{l}2102 \\
2100 \\
\end{array}$ \\
\hline $\begin{array}{l}50 \\
60 \\
80 \\
\end{array}$ & $\begin{array}{l}235 / 4 \\
273 \% \\
353 \%\end{array}$ & $\begin{array}{l}203 \\
203 \% \\
203 \%\end{array}$ & $\begin{array}{l}28 \% \\
28 \% \\
28 \%\end{array}$ & $\begin{array}{l}22 \\
25 \\
34\end{array}$ & $\begin{array}{l}3 / 4 \\
3 / 4 \\
3 / 4\end{array}$ & $\begin{array}{l}53 \\
53 \\
23\end{array}$ & $\begin{array}{l}3: 2 \\
3 ! 2 \\
3: 2 \\
3: 2\end{array}$ & $\begin{array}{l}11 \% / 8 \\
11 \% / 8 \\
11 \%\end{array}$ & $\begin{array}{l}9 / 2 \\
91 / 2 \\
91 / 2 \\
\end{array}$ & $\begin{array}{l}\frac{21}{30} \\
35 \\
48 \\
\end{array}$ & $\begin{array}{l}2 \\
2 \\
4 \\
\end{array}$ & $\begin{array}{l}\text { ADHT-050 } \\
\text { ADHT-050 } \\
\text { ADHT-D80 }\end{array}$ & $\begin{array}{l}\text { Nis } \\
5 \\
\text { Nis }\end{array}$ & $\begin{array}{l}210 \\
280 \\
\end{array}$ \\
\hline $\begin{array}{l}90 \\
109 \\
120 \\
\end{array}$ & $\begin{array}{l}395 / \\
433 / 4 \\
275 / 2 \\
\end{array}$ & $\begin{array}{l}20 \% \\
20 \% \\
35 \\
\end{array}$ & $\begin{array}{l}28 \% / 4 \\
28 \% / 4 \\
42 \% / 4\end{array}$ & $\begin{array}{l}33 \\
42 \\
26\end{array}$ & $\begin{array}{l}3 / 6 \\
3 / 4 \\
3 / 6\end{array}$ & $\begin{array}{l}47 \\
5 \% \\
5 y \\
57\end{array}$ & $\begin{array}{l}34 \\
3: 2 \\
3 ! \\
\end{array}$ & $\begin{array}{l}112 / 8 \\
111 / 8 \\
11 / 6\end{array}$ & $\begin{array}{l}9: 2 \\
9: 2 \\
9: 2 \\
\end{array}$ & $\begin{array}{l}54 \\
60 \\
36 \\
\end{array}$ & $\begin{array}{l}5 \\
5 \\
5 \\
4\end{array}$ & $\begin{array}{l}\text { ADHT-090 } \\
\text { ADHT.103 } \\
\text { ADHT-120 }\end{array}$ & $\begin{array}{l}\text { NS } \\
\text { is } \\
\text { ins }\end{array}$ & $\begin{array}{r}21031 \\
21032 \\
21033 \\
\end{array}$ \\
\hline $\begin{array}{l}60 \\
180 \\
240 \\
\end{array}$ & $\begin{array}{l}35 s / 2 \\
395 / \\
275 / 6 \\
\end{array}$ & $\begin{array}{l}35 \\
35 \\
35 \\
\end{array}$ & $\begin{array}{l}42 \% \\
42 \% \\
42 \%\end{array}$ & $\begin{array}{l}34 \\
35 \\
26 \\
\end{array}$ & $\begin{array}{r}7 / 8 \\
3 / 3 \\
3 / 8 \\
\end{array}$ & $\begin{array}{r}23 \\
2: 2 \\
2 \because 8 \\
2 \div 8 \\
\end{array}$ & $\begin{array}{l}3.6 \\
34 \\
316 \\
316\end{array}$ & $\begin{array}{l}11 \% / 6 \\
19 \% \\
20\end{array}$ & $\begin{array}{l}9 \% / 2 \\
9 \% / 2 \\
i 6^{3} \%\end{array}$ & $\begin{array}{l}48 \\
54 \\
12 \\
\end{array}$ & $\begin{array}{l}8 \\
5 \\
8 \\
\end{array}$ & $\begin{array}{l}\text { ADHT. } 160 \\
\text { ADHT.180 } \\
\text { RDHT.240F }\end{array}$ & $\begin{array}{l}\text { NS } \\
\text { NS } \\
\text { NS }\end{array}$ & $\begin{array}{l}2103 \\
2103 \\
2103 \\
\end{array}$ \\
\hline 300 & $33^{3} \%$ & 35 & $\langle 2 \%$ & 32 & 3 & $5: \div$ & 38 & 20 & $183 / 2$ & 90 & $i 0$ & KDHT.303F & H5 & 2505 \\
\hline
\end{tabular}




\section{政}

\section{High temperature air duct heaters (cont.)}

epplication Guide

celetling heater slza. Refer to Techsele section for examples on determinpisel Section irements. For quick in $\mathrm{kW}$ requirements purposes, the following foresima may be used for slandard conExions:

$$
k W=C F M \times \text { lemp. diH/3000 }
$$

veximum work temperalures. Types NDH and ADHT process air heaters can Dherally be used at the following maxigenen lemperatures shown, provided the minimum air velocity is mainteined unipomly through the heater:

\begin{tabular}{|c|c|c|}
\hline \multirow{2}{*}{$\begin{array}{l}\text { Le Velocity } \\
\left(\sigma_{s e c)} \text {. }\right.\end{array}$} & \multicolumn{2}{|c|}{ Msx. Outlet Alr Temp. "F } \\
\hline & $\overline{A D H}$ & ADHT \\
\hline $\begin{array}{l}6 \\
8 \\
36 \\
6 \\
3\end{array}$ & $\begin{array}{l}800 \\
800 \\
800 \\
800 \\
800\end{array}$ & $\begin{array}{l}1050 \\
1100 \\
1150 \\
1200 \\
1200\end{array}$ \\
\hline
\end{tabular}

Lpilcation assistance. Chromalox ieles/application engineers are available hassist you in the design or selection it equipment. Please contact your local Gronaiox Sales Office it you need enyinering assistance.

\section{Istallation mounting tips}

- Low temperature duct heaters can

be fasteneo direcily to the sheet melal

out work with bolis or sheet metal sows.

Whomperature duct heaters are generally mounted to a field fabricaled and of collar from the ductwork to poson the heater such that the $3^{*}$ insu. anousing is in the same plane as the duct insulation.

Al heaters can be mounted in any poWon; lop, side or bomom (preferred)

thy Minum duct size is $A$ or $L$ amension plus $3 / 8^{\prime \prime}$ and $B$ dimension fos $15 \%^{n}$.
Provlde adequate heater support. Consideration should be given to inslalling hangers or some other means of heater support whenever there is any question about the ability of the ductwork to support the heater weight.

Overtemperature protectlon. All heaters should include an overtemperature (overheal) control whose temperature sensing element is located on the air discharge side of the heater as close to the heater as practical. High temperature ADHT units include an overtemperature (Type $K$ ) thermocouple as siandard.

Additional protection can be achieved by installing an aif flow or pressure differential switch to protect the heater against low ait flow conditions.

Operational controls. Selection of these controls, thermostat, SCR units, contaciors and ele., depenos on the degree of accuracy required, reliability, electrical raling of healer and economic considerations. Refer to Conirol Section.

Fleld power \& control circuit wiring. Must be capable of carrying the electijcal load and be proiected by overcurrent protective devices, such as fusing. circuit breakers or ground favit delection in accordance with the require. ments of the National Electrical Code and local codes as applicable.

Tandem mounting. Multiple healers may be nounted in landem with each other provided the maximum recommended outlet air temperature is not exceeded.
Pressure drop. Depends on the size of heater, its orientation with respect to air flow and the velocity of the air. Curve G-227.2 in Technical Section lists pressure drops for various heaters. Note, if pressure drop must be kept to a minimum, the heater should be mounted in the duct with the narrow width of the heater perpendicular to the air flow.

\section{Optlons available}

Gas tIght design. Achieved by the use of threaded compression fittings with fiber washers to attach heating elemenis to flange-prevents leakage of Gucted air into terminal housing.

Overtemperature protection. Thermocouple welded to the element sheath surface and wired to a lerminal block can be provided for accurête overheat protection. Siandard on high lemperalure units.

Molsture or explosion-resistant terminal housings are available for those applications requiring special terminal prolection.

Speclal ratings or sizes. Chromalox can custom fabricale a duct heater to your particular needs whether it be rating, physical size or other specifi. calions.

Contact your local Chromalox representative for assistance. 


\section{T/8 Technical information/calculation examples}

\section{Examples for heating air/gases}

Heating air in ducts

Problem: A special orying process re. quires that we raise $450 \mathrm{cim}$ of air from $70^{\circ}$ to $150^{\circ} \mathrm{F}$. The existing ductwork which will be used for this purpose is insulated (negligible losses) and meas. ures $2 \mathrm{ft}$. wide by $1 \mathrm{~A}$. high. Power avallable is 240 volis, 3 phase. Calculate the required $\mathrm{KW}$ and select a compatible healer for this application.

Solution: Under siendard conditions air has a specific veight of $.08 \mathrm{lbs} . \mathrm{H}^{3}$ and a specific heal value of .24 Eiu/b/ ${ }^{\circ} \mathrm{F}$.

To find heating capacity in $\mathrm{kW}$

$k W=\frac{W_{T} \times C_{0} \times \Delta T \times 1.2}{3412^{\circ}}$

Where:

$$
\begin{aligned}
W_{T}= & W_{1 .} \text { of eir/hr }(450 \times 60 \times .06) \\
& =2160
\end{aligned}
$$
$=2 i 60$

$\mathrm{C}_{\mathrm{p}}=$ Spec. heal of air $(.24)$

$\Delta T=$ Temp. rise ${ }^{\circ} F(80)$

$3412=$ BTU io kWh conversion for air at other than standatd condilions refer io page T/37.)

$1.2=$ Safeiy facior.

$$
\begin{aligned}
\mathrm{kW} & =\frac{2160 \times 24 \times 80 \times 1.2}{3412} \\
& =14.85
\end{aligned}
$$

For quick estimates, the following for. mula may be used where 3000 is a conversion facior in units of $\mathrm{ft}^{2}$ - ${ }^{\circ} \mathrm{F} / \mathrm{min}-\mathrm{kW}$.

$$
\begin{aligned}
\text { kW } & =\frac{\text { cim } \times \text { iemp. rise }}{3000} \\
& =\frac{450 \times 80}{3000^{-}}=12 \times 1.2=14.4
\end{aligned}
$$

Or: When airilow (tis/min) and lemp. rise ate known, curve G-176S (which shows $15 \mathrm{kVW}$ for this example) may bo used. (This curve does not include contingency allowance).

To select the heater.

In this application there are a fevi choices io be explored. First, consider Chromalox type CAB heaters. Knowing the application requited, $15 \mathrm{~kW}$ leads us to select either the CAB-1511 with chrome sieel elements or the CAB.152 with iron sheath elements rated at 26 Wrin'. The maximum operating sheaih temperatures are $750^{\circ} \mathrm{F}$ for iron and $950^{\circ}$ for chrome steel.

Calculate air velocity through the heater to verify maximum operating sheath temperatutes will not be exceeded.

$$
\begin{aligned}
V & =\frac{F}{A \times 60} \\
\text { Where: } & \\
V \quad & =\text { Air velocily in } \mathrm{Hsec} \\
F & =\text { Air flow in } \mathrm{ft}^{3} / \mathrm{min}(450 \mathrm{cim}) \\
A & =\text { Area of hir. } \\
& \left(i 5^{\circ} / \mathrm{s}^{\prime \prime} \times 21 \% / \mathrm{s}^{\prime \prime}=2.3 \mathrm{H}^{3}\right) \\
& =\frac{450}{2.3 \times 60} \\
& =3.3 \mathrm{H} / \mathrm{sec} .
\end{aligned}
$$

Using curve Gi07S, page T/23, based on an outlet temperature of $150^{\circ} \mathrm{F}$ and a watt density of $26 \mathrm{~W} / \mathrm{in}^{2}$, a velocily in excess of 9 ifsec is requited to keep the sheath temperalure at permissible levels for the CAB.152. This is well above the aclual velocity and rules out the use of the CAB-152. By applying the watl dersity and outlet air tempera. iute to curve Gioss we see that we need a minimum of approximalely 3 fUsec air velocity to maintain a maximuin of $900^{\circ} \mathrm{F}$ sheath lemperature. Since this is lower than aclual velocity, the use of CAB-1511 is acceplable."

- Use of CAB-9519 will tequite a transition in the existing ductwork to accommodate the hezier.

An allernative method 10 be considered would be mounting banks of Finsirip heating elemenis in the ouctwork. Knowing that $15 \mathrm{~kW}$ is required and that our ouct measures $2 \mathrm{t}$. wide $\times 1 \mathrm{ft}$. high and that a chrome sieel sheath is required, we can select the proper Finstrip.

Using curve Gy08S, the maximum at lowable wall density is $26 \mathrm{~W} / \mathrm{in}^{2}$. Elements with vatt densities of 26 W/in ${ }^{2}$ or less are suitable. Since the duct is $2 \mathrm{H}$. wide, consider using OTF-210, 21 inches long, 240 volts, 1250 watts at $21 \mathrm{~W}^{2} \mathrm{n}^{2}$.

$$
\begin{aligned}
\text { No. finstrips reqo. } & =\frac{\text { Operating watts }}{\text { Rated W/elem. }} \\
& =\frac{15,000}{1250} \\
& =12 \text { Finstrips }
\end{aligned}
$$

Use 12 OTF-210 Finstrips mounted sideways with narrow edge facing air. stream. Total number of elements inslalled must be divisable by 3 so they can be connecied in a 3 phase della circuif:
For heating air ducts with tubu. lar elements in a recirculating.
oven set at $975^{\circ} \mathrm{F}$ Heating air in ducls may be accomplished by using slandard lubular ele ments or by using packaged heater assemblies such as Type ADH.

Sieef sheath may be used where the sheath temperature will not exceed $750^{\circ} \mathrm{F}$; alloy sheath may be used for sheath iemperatures up $101600^{\circ} \mathrm{F}$. it. lowable watl densities should be dele:mined by reference to curves G. 151.1 through G-156-1, pg. T/24.

As an example, suppose it wes deler:mined that approaching air tempera. iures were 10 be $975^{\circ} \mathrm{F}$ at 4 t/dsec ais velocity. The lemperature is above $750^{\circ} \mathrm{F}$ so alloy sheath musl be used. : Using curve G-152-1 allowable wast $\cdots$ densities would be 11 W/in ${ }^{2}$ for a shealh iemperature of $1200^{\circ} \mathrm{F}$ or $22:$ : W/in' ${ }^{2}$ for a iemperalure of $1400^{\circ} \mathrm{F}$. A . standard ADH: heater of proper KW raiing, with $22 \mathrm{~W} / \mathrm{in}^{2}$ on the sheath, could: be used.

Special ADH duct heaters, derated in .. oirecled proportion to the watt densities could be used where operating condi- . tions require use of element ratings less than the slandard 22 W/in'.

HNF-2483, Rev, 0

Page D-7 


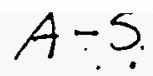

\section{T/9 Technical information/calculation examples Chromalox $^{\circ}$}

\section{Examples for heating air/gases}

\section{Oven heating}

Problem: An oven with inside dimen: srons of 2 t. $\mathrm{H} \times 3 \mathrm{tt} . \mathrm{W} \times 4 \mathrm{H}$. D mainteined at $350^{\circ} \mathrm{F}$ contains a steel tray weighing 40 lbs. This oven is charged with $250 \mathrm{lb}$. of sieel parns which are to we raised from $70^{\circ} \mathrm{F} 10350^{\circ} \mathrm{F}$ in $3 / 4$ tour. Oven has 2 inches of wall insulaion with $400 \mathrm{H}^{3}$ per hour of air ventilaion. What $\mathrm{kW}$ capacity is required?

Weight of steel $=290$ bs.

Specific heat of steel $=.12 \mathrm{Btu} / \mathrm{hb} /{ }^{\circ} \mathrm{F}$

Weight of air $=.080 \mathrm{lb} / \mathrm{h}^{3}$ at $70^{\circ} \mathrm{F}$

Specific heat of air $=.24 \mathrm{Biu} / \mathrm{lb} /{ }^{\circ} \mathrm{F}$

Temperaluse ise $=280^{\circ} \mathrm{F}$

Heat loss $/ 2$ in. insul. $=18 \mathrm{~W} / \mathrm{H}^{2} / \mathrm{hr} @$

$280^{\circ} \mathrm{F}$ lemp. ditference (curve G.126S),

Dage $T / 22$.

Sulface arealoven $=52 \mathrm{ft}^{2}$

Tine $=3 / 4 \mathrm{hr}$.

Airlow taie $=400 \mathrm{~h}^{3} / \mathrm{hr}$.

For oven applications add $30 \%$ to cover coor losses and contingencies.

?े

Heating rooms

kithough a complete analysis should be performed tor room heating using the

NOINA handbook or the ASHRAE guide, quick estimeies of the $\mathrm{kW}$ capacity can

be oblained using the following

procedure.

Problem: A warehouse room measures $20 \mathrm{f}$. long $\times 13 \mathrm{t}$. wide $\times 9 \mathrm{ft}$. high. The building is poorly constructed and consists of corrugated metal sides with a plywood and lar paper roof. Determine the $\mathrm{KW}$ capacity required to maintain

the warehouse at $70^{\circ} \mathrm{F}$ while the out-

side temperature is $O^{\circ} \mathrm{F}$.

Solution:

i. Calculate the volume of the room. 20

$\times 13 \times 9=2,340 \mathrm{~F}^{3}$.

2. Refer to the curve chart shown. Use curve 4 which corresponds to the desigDatied conditions.

3 . If the volume of the room is larger Vian the chart values divide by $2,3,4$

elc. until the frial volume fits the curve.

(Does not apply in this case.) Then

selecl healer from this volume. Multiply

hezlers selected by the number used to

iflect the trial volume.

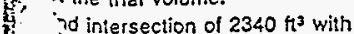

F. 54

$m$ this we can see that $9.3 \mathrm{~kW}$ is re. ined. Select a $10 \mathrm{~kW}$ unit blower The aler.

foaler selection: Depending on re-

Quitemenis, types UB, LUH or VUH

felers woulo be suitable for this appli-
Solution:

1. Calculate $\mathrm{kWh}$ required to heat model.

$k W h=\frac{W_{r} \times C_{p} \Delta T}{3412}=2.86$

Where:

$W_{T}=W t$. sieel/lbs $(290)$

$C_{p}=$ Spec. ht. stl. (.12)

$\Delta T=$ Temp rise/ ${ }^{\circ} \mathrm{F}(280)$

2. Calculate $\mathrm{kWh}$ required to heat ventilaled air

$k W h=\frac{A_{E} \times H \times A_{W T} \times C_{0} \times \Delta T}{3412}=.47$

Where:

$A_{W T}=$ Wt. of air (.080)

$C_{p}=$ Spec. ht. air (.24)

$\Delta T=$ Temp. rise (280)

$H=$ Time/hr (.75)

$A_{F}=$ Air flow rate $(400)$
3. Calculate surface losses

$\mathrm{kWh}=\frac{\mathrm{F} \times \mathrm{E} \times \mathrm{H}}{1000}=.70$

Where:

$E=$ Heat loss $W / \mathrm{t}^{2} / \mathrm{hr}(18)$

$F \quad=$ Suriace area $\hbar^{2}(52)$

$H=$ Time/hr (.75)

4. Combine sleps 1,2 and 3 .

$k W h=2.86+.47+.70=4.03$

$\mathrm{kW}=\frac{\mathrm{kWh}}{\mathrm{H}}=\frac{4.03}{.75}=5.37$

For oven applications, add $30 \% 10$ cover door losses and contingencies. Therefore: requited $\mathrm{kW}=5.37 \times 1.30$ $=6.98 \mathrm{~kW}$.

To select the heater

Chromalox type OV oven heaters would be suitable for this application. In this case you would use 2 standard OV.38 units raled at 3800 watts each.

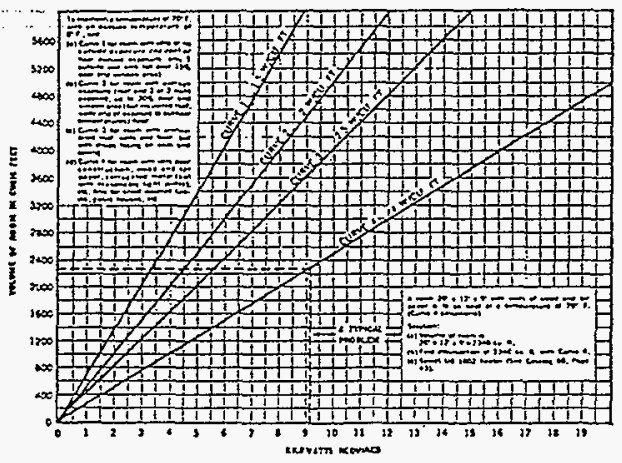

HNF-2483, Rev. 0

Page D-8 tion. 
HNF-2483, Rev, 0

W320-28-006

Equipment Sizing \& Selection Recirculation Condenser

E- $\mathbf{i}$ 
KAISER ENGINEERS HANFORD

CALCULATION IDENTIFICATION AND

INDEX
Page $h$ of 6

$5-4-94$

This sheet shows the status and description of the attached Design Anatysis sheets. Discipline HVAC wo/Job No. ER 4319

Calculation No. 132028006 Project No. \& Name W-320 Tank 241 CI06 STucing

Calculation Item Equipment Sizing \& Selection, Recirculation Condenser

These calculations apply to:

Dwg. No. $\mathrm{H}-2.818480$

Rev. No.

Dwg. No.

Rev. No.

Other (Study, CDR)

Rev. No.

The status of these calculations is:

[] Preliminary Calculations

[X] Final Calculations

[] Check Calculations (On Calculation Dated)

[] Void Calculation (Reason Voided,

Incorporated in Final Drawings?

This calculation verified by independent "check" calculations?

[] Yes [X] No

Original and Revised Calculation Approvals:

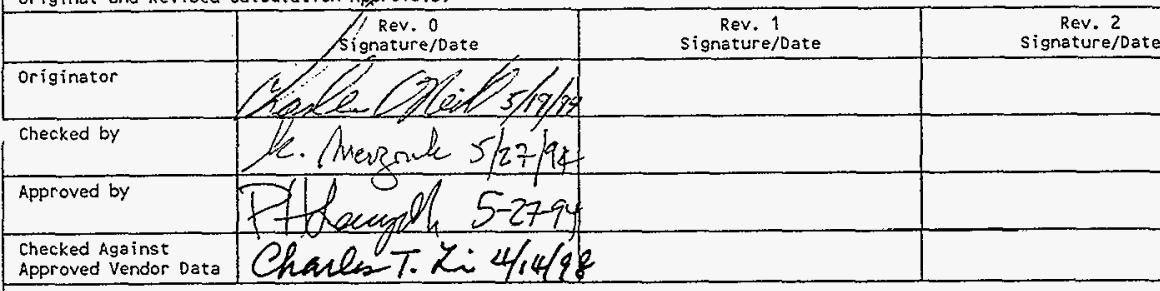

INDEX

Design Analysis

Description

Page No.

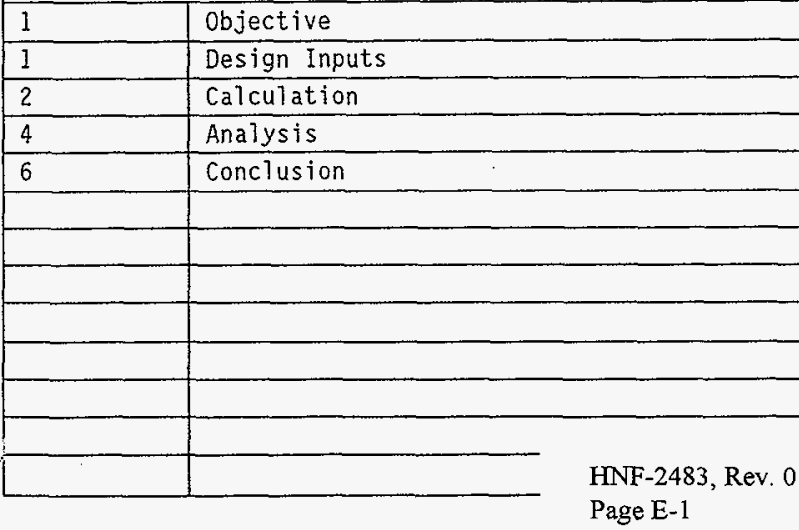

KEH $0378.00(06 / 92)$ KEF072 
DESIGN ANALYSIS

client Westinghouse

subject Equipment Sizing \& Selection, Recirculation Condenser

Location

OBJECTIVE: The objective of this analysis is to make a rough check of vendor proposals and to recommend a condenser for use in the $W-320$ tank ventilation system.

DESIGN INPUTS:

Criteria and Sources:

1.) Functional Design Criteria WHC-SD-W320-FDC-001 Rev 2.

2.) LOI 9359770 Rev 4 .

Given or Known Data:

1.) 235,080 BTU/HR to be removed, from $\mathrm{H}-2-818479$.

2.) Air inlet temperature $-95^{\circ} \mathrm{F}$, saturated, from $\mathrm{H}-2-818479$.

3.) Air outlet temperature $-40^{\circ} \mathrm{F}$, saturated, from $\mathrm{H}-2-818479$.

4.) Air flow 1090 ACFM $70^{\circ} \mathrm{F}$, from $\mathrm{H}-2-818479$.

5.) Air stream is supersaturated with $100 \mathrm{mg} / \mathrm{m}^{3}$ of aerosols. The aerosot is composed of $10 \%$ solids and $90 \%$ liquids. The Tiquid portion is composed of $80 \%$ water and $20 \%$ solids in solution. All aerosols are less than $10 \mu \mathrm{m}$ in size, from LOI 9359770 Rev 4.

6.) Cooling fluid - 46\% Propylene Glycol/Water Solution, from W320-H-007.

7.) Condenser will be skid mounted and located indoors

8.) HVAC overalt flow diagram as shown on $\mathrm{H}-2-818470$.

Methods to be Used:

Standard heat transfer and psychometric equations.

References/Sources:

1.) ASHRAE Handbook of Fundamentals, 1993.

HNF-2483, Rev. 0

ХEH $0037.00(06 / 92)$ KEF055
Revision 0

Page No. 1 of 6

sy Charles o'Neill

B. Arymh 


\section{KAISER ENGINEERS}

HANFORD
DESIGN ANALYSIS

WOIJOb NO. ER4319

Client: Westinghouse Hanford Company

Subject Equip. Sizing \& Selection, Recirc. ConderDate 04-06-94

Selection

Checked $5 / 27 / 94$

Revised
Caic. No. W320- $x=006$

Revision 0

Page No. 2 of 6

\section{CALCULATION}

EXHAUST AIR STREAM

Inlet Conditions $95^{\circ} \mathrm{F}$ Saturated

$$
\begin{aligned}
& C_{p}=0.24 \cdot \frac{B}{(1 b} \frac{w}{F)} \\
& q_{a}=1220 \cdot \frac{1^{3}}{\min } \quad \text { Maximum flow rate } \\
& \mathrm{w}_{3}=0.036 \cdot \frac{\mathrm{lb} w}{\mathrm{~b}} \\
& h_{s i}=63.3 \cdot \frac{\mathrm{But}}{\mathrm{ib}} \\
& w_{2}=0.0052 \cdot \frac{1 w_{w}}{l b_{a}} \\
& h_{s 2}=15.2 \cdot \frac{B w}{1 b_{a}}
\end{aligned}
$$

PROPYLENE GLYCOL/WATER SOLUTION $46 \%, 33^{\circ} \mathrm{F}$ ASHRAE FUNDAMENTALS HANDBOOK 1993

$$
\begin{aligned}
& \rho_{s}=65.5 \cdot \frac{\mathrm{lb}}{\mathrm{fi}^{3}} \\
& \mathrm{c}_{\mathrm{ps}}=0.845 \cdot \frac{\mathrm{Btu}}{\mathrm{Jb} \cdot \mathrm{F}} \\
& \Delta \mathrm{T}=5 \cdot \mathrm{F}
\end{aligned}
$$

$\quad l b_{a}:=l b$
Defining variables $\quad F:=R-460 \cdot R$ for Mathcad

Btu $:=778.17 \cdot \mathrm{ft} \cdot 1 \mathrm{~b}$

$\mathrm{lb}_{\mathrm{w}}:=\mathrm{lb}$ 
KAISER ENGINEERS

\section{HANFORD}

Client: Westinghouse Hanford Company

Subject Equip. Sizing \& Selection, Recirc. CondeDate 04-06-94

Selection

Location:
DESIGN ANALYSIS
Checked $5 / 27$ Revised
Calc. No. W320-H:006

Revision 0

Page No. 3 of 6

WOJJob No. ER4319

By Charles O'Neill

By

\section{CALCULATION:}

Exhaust Air

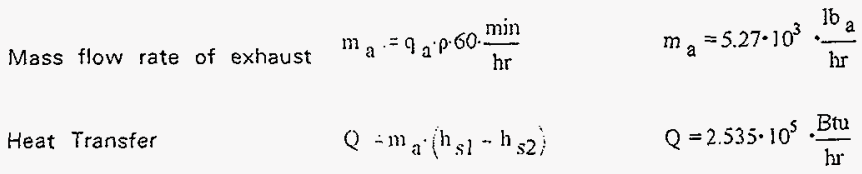

Water Condensed

$B_{h_{1} .20}=m_{a} \cdot\left(w_{1}-w_{2}\right) \quad L B_{h .20}=162.328 \cdot \frac{b b_{w}}{h r}$

Propylene Glycol

Heat Transfered to Glycol

$Q_{g}=Q$

$Q_{\mathrm{g}}=2.535 \cdot 10^{5} \cdot \frac{\mathrm{Btu}}{\mathrm{hr}}$

Glycol flow Rate

$$
\begin{array}{ll}
M_{g}=\frac{\mathrm{Q}_{\mathrm{g}}}{\Delta \mathrm{r} \cdot \mathrm{C}_{\mathrm{ps}}} & \mathrm{M}_{\mathrm{g}}=6 \cdot 10^{4} \cdot \frac{\mathrm{lb}}{\mathrm{hr}} \\
\mathrm{GPM}=\frac{\mathrm{M}_{\mathrm{g}}}{\rho_{\mathrm{S}}} \cdot 7.48 \cdot \frac{\mathrm{gal}}{\mathrm{ft}^{3}} \cdot \frac{\mathrm{hr}}{60} \cdot \frac{\mathrm{min}}{\mathrm{min}} & \mathrm{GPM}=114.201 \cdot \frac{\mathrm{gal}}{\mathrm{min}}
\end{array}
$$

HNF-2483, Rev. 0

Page E-4 
client Westinghouse

Wo/Job no. ER 4319

subject Equipment Sizing \& Selection, Recirculation Condenser

Location

Date 04-06-94

checked $5 / 27 / 94$

Revised

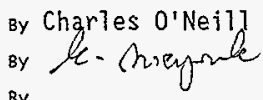

\section{ANALYSIS:}

The proceeding calculations provide values to make a reasonable check of vendor proposals.

The design and manufacture of heat exchangers is a well developed process that is beyond this analysis. The ability of a shell and tube or a spiral heat exchanger to achieve the desired results is not in question. Instead this discussion will examine how the differences in design of shell and tube and spiral heat exchangers impact the $W-320$ ventilation system.

The air stream entering the heat exchanger is expected to be super saturated at $95^{\circ} \mathrm{F}$. The heat exchanger is to be designed to lower the exiting air stream to $40^{\circ} \mathrm{F}$ saturated. Both heat exchangers as proposed will meet these conditions.

\section{SHELL AND TUBE}

The shel] and tube heat exchanger is a four pass, U-tube unit with the air on the shell side. Air inlet and outlet flanges are mounted vertically on the top with a condensate drain on the bottom. The total length of the exchanger is 102 inches and the diameter is 23 inches including flanges.

Sealing

The shell and tube exchanger employs a fixed tubesheet at one end of the exchanger. The tubes are rolled into the sheet. This is a standard design and there is no reason to expect leaks at the tubes if the tube bundle is assembied properiy.

Drainage/Contamination

The shell and tube exchanger will condense three tenths of a gallon per minute per the data sheet. The condensate will drain through a $3 / 4$ inch outlet on the bottom of the she11. Inside the shell the tubes are supported by baffles that also act to direct the air across the tube bundle. These baffles will have a $V$ notch at the bottom of the shell to allow the condensate to pass to the drain. The condenser can be sloped to promote condensate flow to the drain.

The joint where the tubes are rolled into the tubesheet is a likely spot for contamination to become lodged. Tight quality control will minimize gaps between the tubes and the tubesheet, but cannot eliminate them.

\section{Cleaning/Decontamination}

Fouling on the inside of the tubes is not a big concern. An inhibited glycol solution at these temperatures will not plate out on the inside of the tubes. The shell side may see some deposits from the insoluble 
client Westinghouse

subject Equipment Sizing \& Selection, Recirculation Condenser
Ho/Job No. ER 4319

Date 04-06-94

checked 5/27197

Revised
By Charles O'Neill

By

By

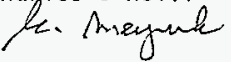

particles that are not washed from the exchanger by the condensate. Chemical cleaning will be required to remove any deposits on the shell side.

Decontamination of the shell and tube exchanger at completion of $W-320$ would probably be accomplished by chemically flushing the inside of the shell with a nitric acid solution. The tube bundle would have to be pulled to remove any remaining contamination.

\section{Layout}

The shell and Tube heat exchanger will require $13 \mathrm{sq}$. ft. of floor space. The ventifation skid layout provides adequate space for the shell and tube heat exchanger. The current layout would allow the exchanger to be mounted above the air heater while still providing room for removing the heater. The location of the air inlet on the top of the unit permits sloping the air duct down towards the tank for drainage of condensate back to the tank.

Cost

The cost of the shell and tube exchanger is $\$ 13,600$. The vendor making this proposal is well known name in this field so this price is probabiy a good indicator of what a quality piece of equipment will cost.

\section{SPIRAL}

The spiral type heat exchanger consists of two sheets of stainless steel that are welded together at one end and then wound into a spiral with a fixed gap between the sheets. The sides of the spiraled sheets are then welded together in such a way as to form two separate channels. The spiral is installed inside a housing and end plates are fitted to each side to seal the channels.

The heat exchanger will be mounted with the spiral in the vertical axis. The air inlet would be on the bottom at the center and the air would spiral outward. The coolant would enter at the side of the housing and spiral inward and leave from the top at the center.

The total size of the unit is 45 inches in diameter and 88 inches tall. It will take $16 \mathrm{sq}$. $\mathrm{ft}$. of floor space.

Sealing

The two channels are sealed from each other by welding the edges of the sheets at each end. The end plates utilize a full face gasket to prevent short circuiting of the fluids. The gasket material can be chosen to meet service conditions.

Drainage/Contamination

HNF-2483, Rev. 0

Page E-6 
client Westinghouse

subject Equipment Sizing \& Selection, Recirculation Condenser
Ho/Job No. ER 4319

Date 04-06-94

checked $5727 / 44$

Revised
By Charles O'Neijl

H. Maynata

Location

By

The spiral heat exchanger will condense four tenths of a gallon per minute per the data sheet. The condensate will drain through a two inch outlet on the bottom end plate. As the condensate forms it falls to the bottom of the exchanger and is pushed outward through the spiral to the drain by the air flow. The spiral exchanger cannot be sloped like the shell and tube to promote drainage.

The welded joint formed at each end of the channels provides a crack for radioactive material to enter. This problem will be minimized because the joint is located at the top of the air channel during fabrication.

Cleaning/Decontamination

Fouling of the coolant channel is not a concern. The air side channel may see some deposits from the insolub?e particles that are not washed from the exchanger by the condensate. Chemical cleaning will be required to remove any deposits on the air side during operation.

Decontamination of the spiral exchanger would be accomplished by chemically washing with a nitric acid solution. If additional cleaning is required the end plates can be removed which exposes both channels for mechanical methods.

Layout

The major benefit of the spiral exchanger in this application is its compact size. However, the spiral heat exchanger requires the same floor space as the shell and tube unit. The spiral exchanger does not provide any benefits to the layout.

Cost

The cost of the proposed spiral exchanger is $\$ 38,000$. This is twice the cost of the shell and tube. The cost may drop when other vendors are contacted but the spiral exchanger will probably still be more expensive than a shell and tube.

\section{CONCLUSION}

The shell and tube heat exchanger is the preferred choice for this application. The compact size of the spiral exchanger does not affect the size of the ventilation skid which is its major benefit. The shell and tube exchanger can be mounted to promote drainage and the nozzle orientation allows the inlet piping to be sloped to drain back to the tank.

HNF-2483, Rev. 0

Page E-7 
HNF-2483, Rev. 0

W320-28-007

Chiller Skid System Sizing and Selection

$F-i$ 


\section{CATCUIATION
IDEMTIEICATION AND INDEX}

Page $t$ of $t$

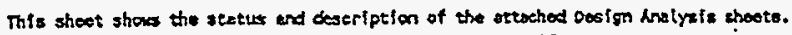

Diseipline 28/HVAC

co/sob no. ER4319

calculation wo. W320- - - -007

$4-19-94$

Projest xo. ase W-320 Tank 241-C-106 laste Retrieval

celavertion Itea ChilTer Skid System Sizing and Selection

These esleutations apply to:

oxg. ko. H-2-818561

Rer. No. 0

Dxg. No.

Rer. No.

other (study, COR) N/A

Rav, No. N/A

The status of these celculations is:

[] Preliefnary caleutations

[X]. Enol celculations

[] Cheek Calertations (on Caleulation dated)

[1 Void calculation (Reasen Yoldeo )

Incorporated in Ifrat Drewtres?

[] $[X]$ No

This alastation veriffed by independent "chesti" calaulotions? [] Yes [X] No

Original and Reviced caleulation Aporovals?

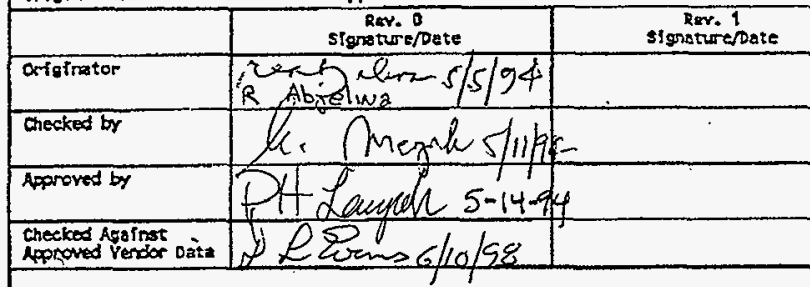

Deseription

Design Mralysits

Poge ko.

\begin{tabular}{l|l}
\hline 1 & Caiculation Identification and Index
\end{tabular}

if Design Calculation Index (ICF KE OakTand)

\begin{tabular}{l|l}
\hline $1-27360$ Calculations \\
\hline
\end{tabular}

\begin{tabular}{|l|l|l}
\hline & \\
\hline
\end{tabular}

\begin{tabular}{|l|}
\hline stgrature/pate \\
\hline \\
\hline \\
\hline
\end{tabular}

\begin{tabular}{|c|c|}
\hline & \\
\hline
\end{tabular}




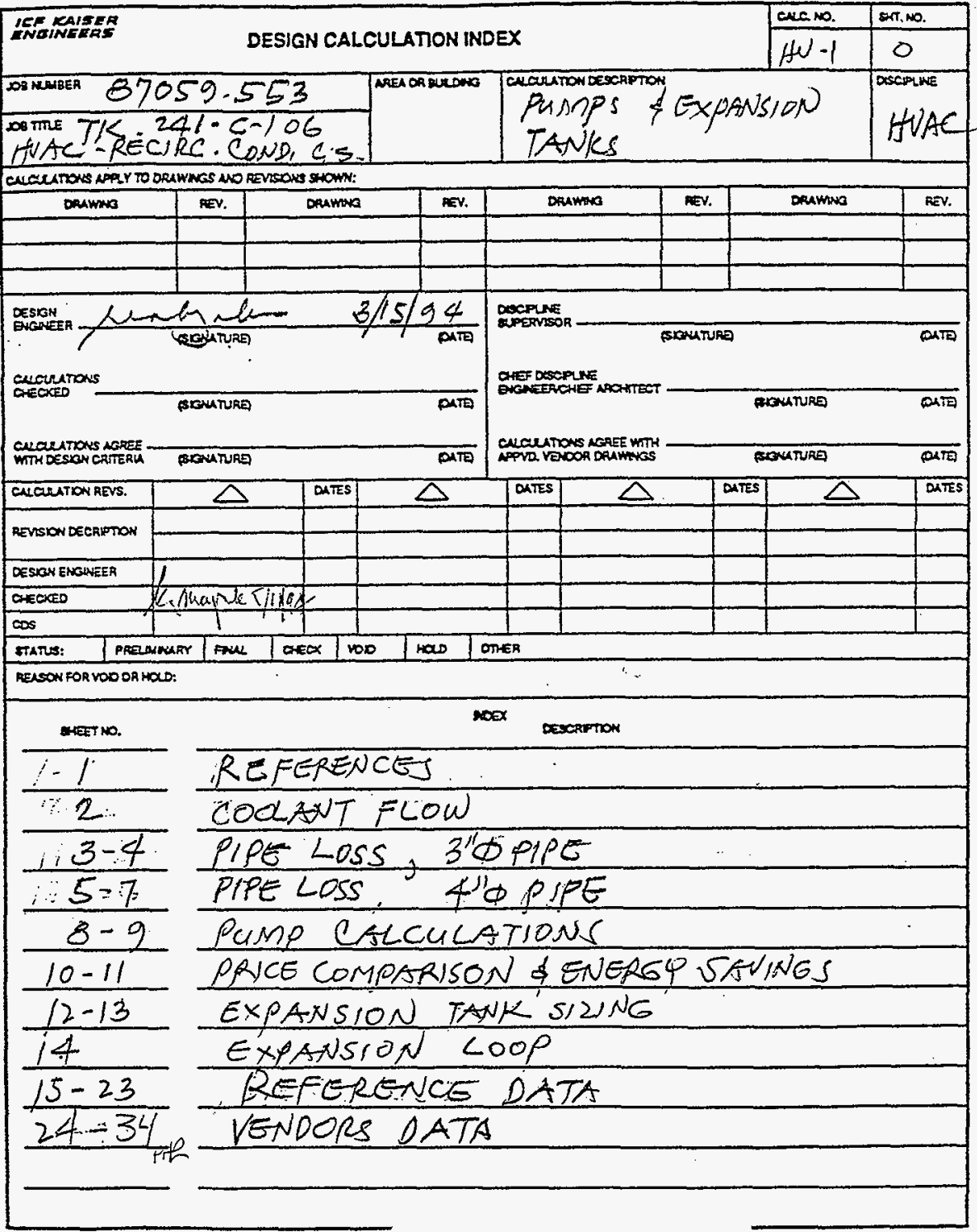




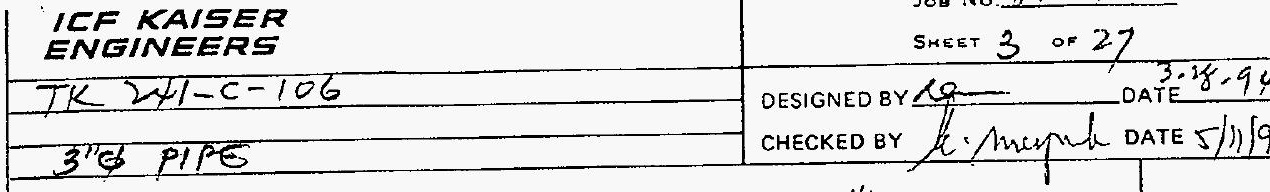

TO DETERMINE PIPE LOSS THER h'" PIPE

1. GATE VAUVE

$$
H_{0}=13 \text {, FOR } 7 \text { VANE }=\frac{3}{12} \times 13 \times 7=
$$

23

2. Butterffey VALVE: $\frac{L}{D}=40$ :

par 4 BUTTERFLY VALVE $=4 \times \frac{3}{12} \times 40=40$

3. ANgle value

$$
\begin{aligned}
& L \\
& \frac{L}{D}=145 ; L=\frac{3}{12} \times 145
\end{aligned}
$$

36

F. CHECK VANE

$$
\frac{c}{D}=135 ; \quad L=\frac{3}{12} \times 135
$$

.34

5. $45^{\circ}$ elBows:

$$
\frac{L}{D}=16 \text {; for } 12 \mathrm{CL}=12 \times \frac{3}{1.2} \times 16=
$$

48

6. FOR $90^{\circ} \mathrm{ELBOWS}$.

$$
\frac{C}{D}=20 \text { fOR } 30 E C=30 \times \frac{3}{12} \times 20
$$

150

7. AR SEPATATOR

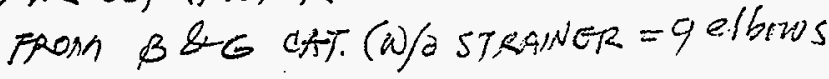

$$
=\frac{3}{12} \times 9 \times 20
$$

SUB-TOTAL

8 PIPE LENGTH

TOTAL PIPE LENGTH

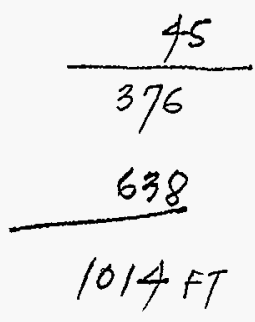

HNF-2483, Rev. 0

Page F-5 


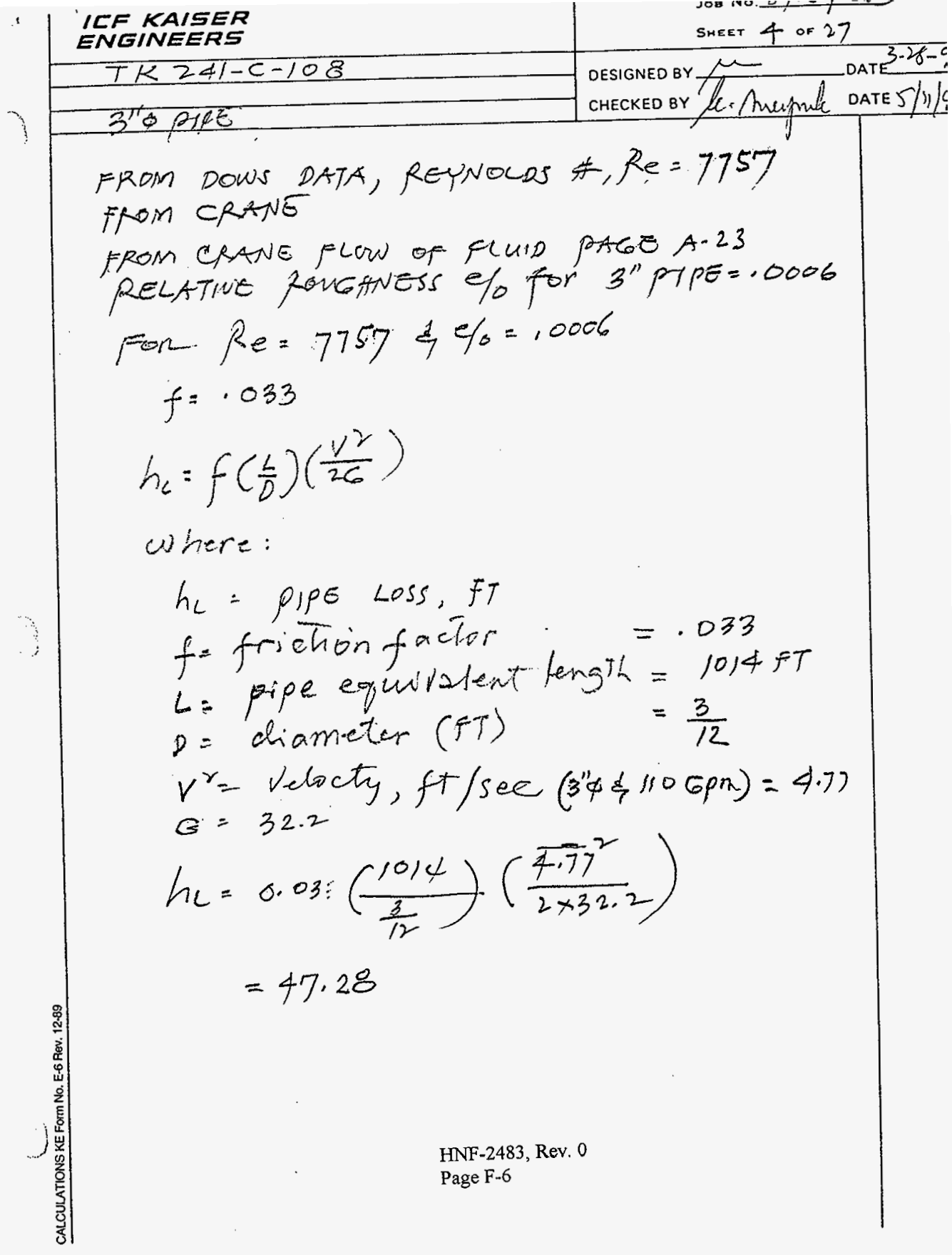




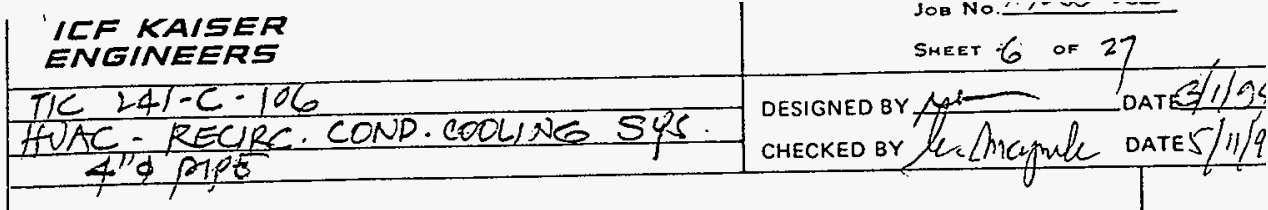

EQUNALENT LENGTH:

1. Gate VALVE (FROM PSID, NT Gate VaLUES)

$$
4_{D}=13 \text { FOR } 7 j L=\frac{4 \times 13}{12} \times 7=
$$

30,33

- RUTTERTLLY VALUES

$$
H_{D}=40 ;, 00 R+B . Y_{1}=\frac{4 \times 40}{12} 4=
$$

3. angle valve

$$
L D=145 ; \quad L=\frac{4}{12} \times 145
$$

48.33

4. EHECK YALVE:

$$
\frac{L}{D}=135 ; L=\frac{4}{12} \times 135=\ldots+4.0
$$

E. $45^{\circ}$ ELBOWS

$$
\frac{L}{D}=16 ; \text { FOR: } 12 E L ; L=\frac{4}{12} \times 16 \times 12=64
$$

6. $90^{\circ}$ ELBOWS

$$
\begin{aligned}
& 90^{\circ} \text { ELBOWS } \\
& \frac{L}{D}=20, \text { FOR } 30 E L=\frac{4}{1 F_{3}} \times 20 \times 30=200
\end{aligned}
$$

7. air sepARATOR

$$
\begin{aligned}
& \text { FROM } B \& G C A T,(\omega / O S T R A I N E R)=9 \text { eLBOWS } \\
& =9 \times \frac{4}{12} \times 20=\frac{60}{504.00}
\end{aligned}
$$

8. TOTAL PIPE LENGTH

$$
\frac{638}{1139}
$$

HNF-2483, Rev. 0

Page F-8 


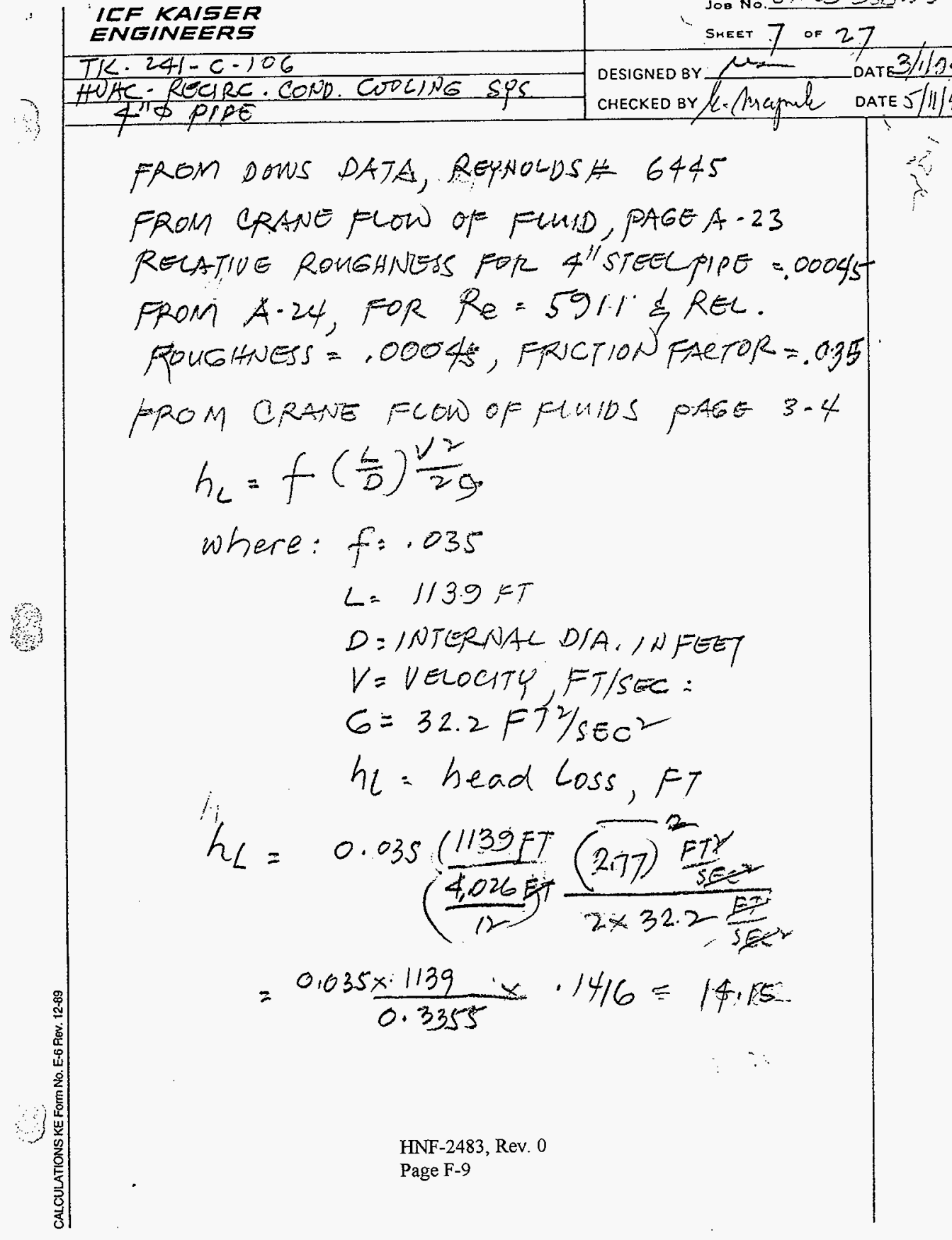




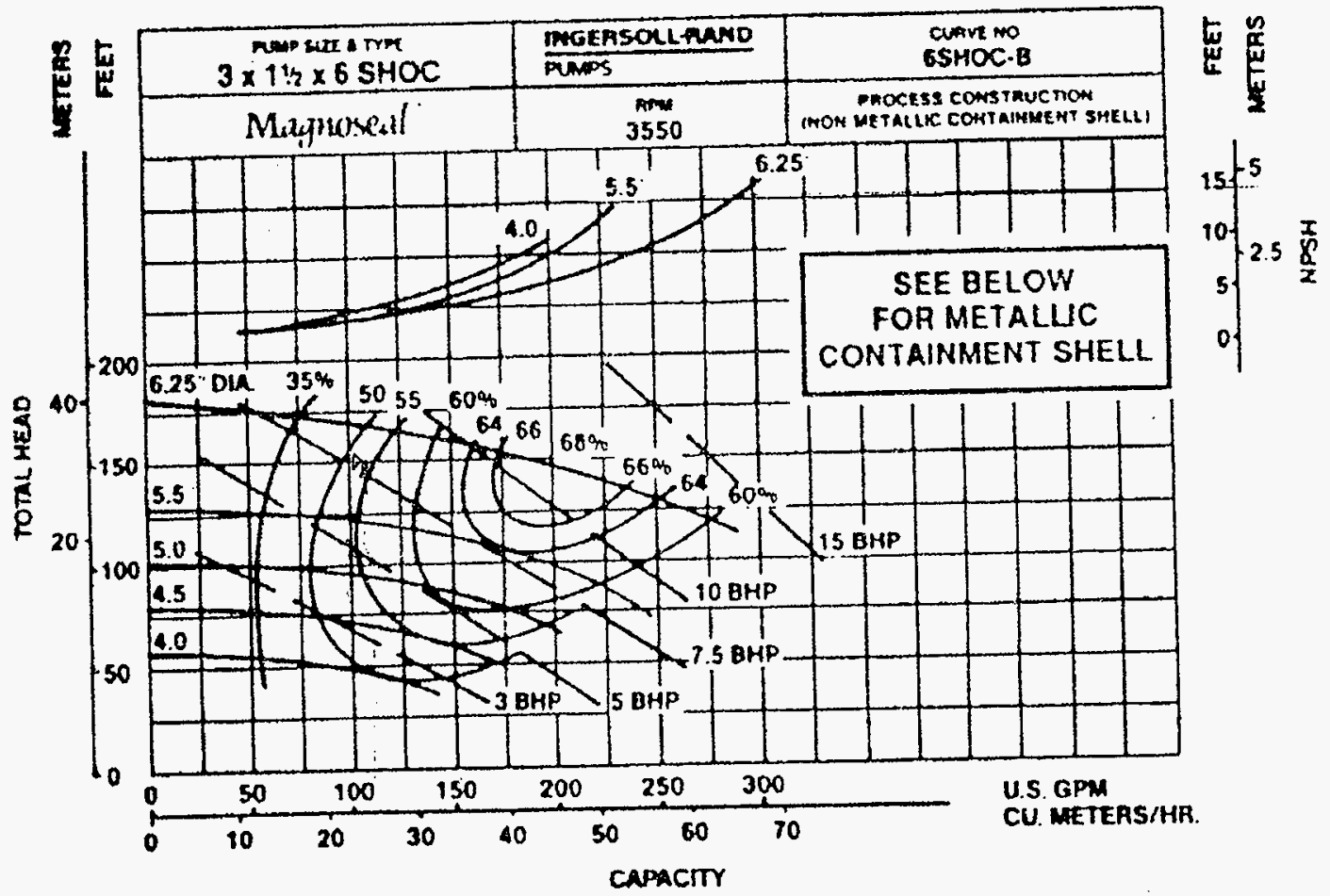









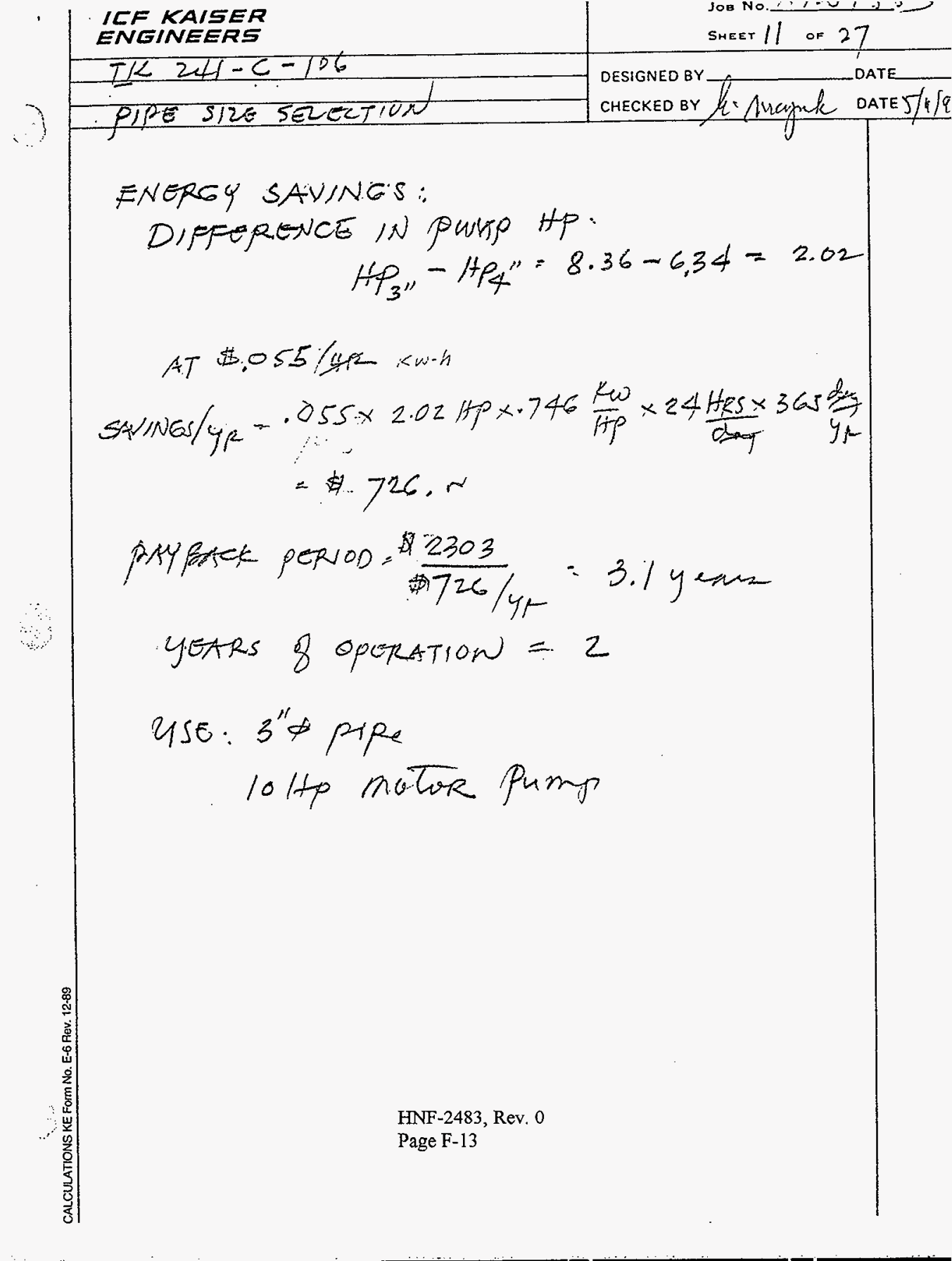




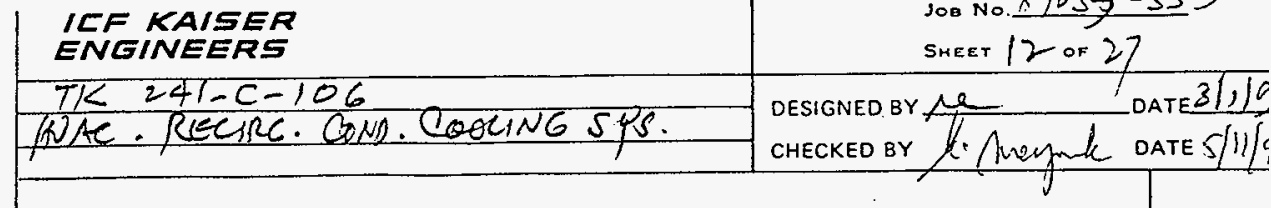

TO SIZE EXPANSION TANK

1. PIPE LENGTH.

SIZE

$$
\begin{aligned}
& \text { VoluME }=\frac{\pi D^{2}}{\frac{1}{4} \times 144} \times 638 \\
& =\frac{\pi(4)^{2}}{4 \times 14^{4}} \times 638=56 \text { cut }
\end{aligned}
$$

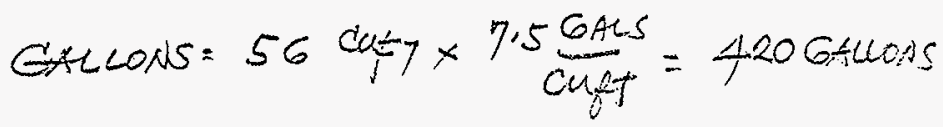

2. CHILLER

3. CONDENSER
638 FT (REF. D)

4 4"

$\mid$

RELATIVE ELEVATION OF SYSTEM

AND PUMP $=646-633=13-0^{\prime}=$

$$
=13 \times \frac{66.57}{144}=6 \text { psi }
$$

HNF-2483, Rev. 0

Page F-14 
IHINGS YOU MUST KNOW:

\begin{tabular}{|c|c|c|c|}
\hline I TEM & Symbol & $\begin{array}{c}\text { Reference } \\
\text { Table } \\
\text { Formula }\end{array}$ & ANSWER \\
\hline 1. Total System Water Content & Vs & $\mathrm{B}, \mathrm{C}, \mathrm{D}$ & 4505 \\
\hline 2. Average Design Water Temperature & $\mathbf{t}$ & - & 3.2 .5 \\
\hline $\begin{array}{l}\text { 3. Minimum Fill Pressure (Pre-charge) } \\
\text { Cigpsig(Static) }+4 \text { Psig(top of sys) }\end{array}$ & Pf & A & psig \\
\hline 4. Maximum Operating Pressure & Po & - & psig \\
\hline 5. Tank Mounting & - & - & Horiz. $\_$Vert. \\
\hline
\end{tabular}

TANK SIZING AND SELECTION

6. Net Water Expansion Factor

7?. Correction Factor, if Glycol

8. Expansion Volume, Multiply

Line (1) $450 \times(6) .004 \times(7) 1.8$

9. Acceptance Factor

10. Minimum Tank Volume, Divide Line (8) $3.24+$ by (9) 175

\begin{tabular}{|c|c|c|}
\hline- & F & 1004 \\
\hline- & $\mathrm{E}$ & 1.8, water $=1$ \\
\hline Ve & - & $3,2.40 \mathrm{Gal}$ \\
\hline Ae & $\mathrm{G}$ & 0.725 \\
\hline Vt & (6) & 2.35 \\
\hline
\end{tabular}

11. Select Tank - See Line (5)

Select Tank with Tank and Acceptance Volumes Equal or Greater Than

Answers in Line $(8)$ and (10).

12. Selection\#1: Mode1 Sx-30V, Size 16 (Gal.), Ac 6 Gal.

12A. Alternate Selection: Model Size (Gal.), Ac Gal. With Two Tanks: Model - Size (Gal.), Ac Gal. TOTAL:

JOB NAME

LOCATION

ENGINEER

CONTRACTOR

SALES REPRESENTATIVE DATE

HNF-2483, Rev. 0

Page F-15 


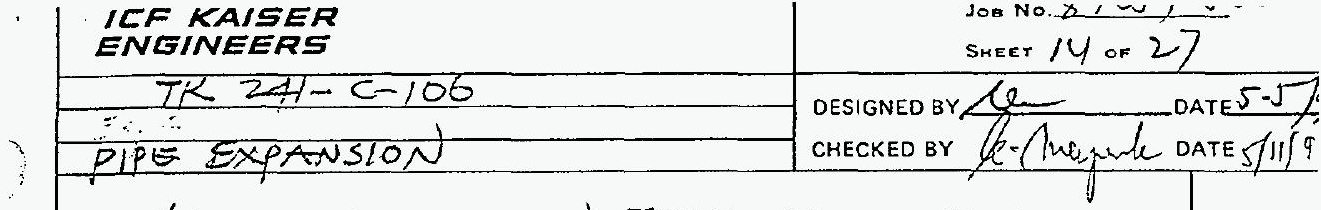

ASSUME INSTALLATION TEMPERATURE OF PIPE $=85^{\circ} \mathrm{F}$

WATER TEMP. $=31 \%$

$$
\Delta t=85^{\circ} \cdot 31=54^{\circ} \mathrm{T}
$$

FROM RICKWIL CAT. (CAT, PAGE $16 \cdot E)$, SEE PAGE 22, PIPE THERMAL EXPANSION FOR $54^{\circ} \mathrm{F}$ AT IS CALCULATED AS Fuchs:

TABLE TEMP BASE IS - $20 \%$ THERFORE USE THERMAL EXPANSION FOL TEMPERATURE $=54.20^{\circ}=34^{\circ} \mathrm{F}$.

BY INTERPOLATION,

TISERMAL EXPANSION $=0.389 \mathrm{inCh} / 100 \mathrm{FT}$

PER PETE LANGOWSKI MEMO 1/7/gU, PIPE LENGTH $=279 \mathrm{FT}$.

NO: OF ELBOWS $=14$

THERMAL EXPANSION FOR $279 F T=$

$$
279^{\prime} \times \frac{.389^{\prime \prime}}{100^{\prime}} \text { " } 1.08^{\prime \prime}
$$

PIPE EXPANSION IS MINIMAL AND CAN BE HANDLED BY: SYSTEM ELBOWS. IF PIPING LOOP WILL BE USED, THE EXPANSION LOOP DIMENSION PER RICKWIL CAT. PAGE 18-E:

$$
\begin{aligned}
& 2 H+\omega=9 \cdot 5^{\prime} \quad \omega / t \in R E: \omega=\frac{H}{2} \quad \begin{array}{ll}
\text { HNF-2483, Rev. } 0 \\
\text { Page F-16 }
\end{array} \\
& 2 A+H / 2=9.5 ; \quad H+=4 ; \quad \omega=2
\end{aligned}
$$


Heat Transfer Coefficient and Pressure Drop DOWFROST HD Fluid (61.5 \% Solution)

(At 46.3 Percent Weight Glycol)

Jw Rate: 4.77 feet/second

Temperature: $31.0 \mathrm{~F}$

Pipe or tube size: 3.068 inches
Density: $66.57 \mathrm{lb} / \mathrm{ft}^{\wedge} 3$

Specific Heat: 0.811 Btu/1b-F

Thermal Conductivity: $0.2095 \mathrm{Btu} / \mathrm{hr}-\mathrm{ft}-\mathrm{F}$

Vapor Pressure: 0.08 psia

Viscosity: $\quad 37.77 \mathrm{lb} / \mathrm{hr}-\mathrm{ft}$

Prandtl No: 146.1

Reynolds No: $\quad 7,757$

The correlation for film coefficient is not valid for Re<10,000.

$\begin{array}{lllll}\text { RETURN } & \text { ESC } & \text { M } & \text { Prtsc } & \text { Q } \\ \text { Next } & \text { Prior } & \text { Main } & \text { Print } & \text { Quit } \\ \text { Menu } & \text { Screen } & \text { Menu } & \text { Screen } & \text { Now }\end{array}$

HNF-2483, Rev. 0

Page F-17 


\section{Heat Transfer Coefficient and Pressure Drop DOWFROST HD Fluid (61.5\% Solution) \\ (At 46.3 Percent weight Glycol)}

Iw Rate: 2.77 feet/second

Temperature: $31.0 \mathrm{~F}$

Pipe or tube size: 4.026 inches
Density: $66.57 \mathrm{lb} / \mathrm{ft}^{\wedge} 3$

Specific Heat: 0.811 Btu/lb-F

Thermal Conductivity: $0.2095 \mathrm{Btu} / \mathrm{hr}-\mathrm{ft}-\mathrm{F}$

Vapor Pressure: 0.08 psia

Viscosity: $\quad 37.77 \mathrm{lb} / \mathrm{hr}$-ft

Prandtl No: 146.1

Reynolds No:

5,911

The correlation for film coefficient is not valid for Re<10,000.

$\begin{array}{llllc}\text { RETURN } & \text { ESC } & \text { M } & \text { PrtSc } & \text { Q } \\ \text { Next } & \text { Prior } & \text { Main } & \text { Print } & \text { Quit } \\ \text { Menu } & \text { Screen } & \text { Menu } & \text { Screen } & \text { Now }\end{array}$

HNF-2483, Rev. 0

Page F-18 


\section{Schedule (Thickness) of Steel Pipe Used in Obtaining Resistance \\ Of Valves and Fittings of Various Pressure Classes by Test*}

\begin{tabular}{|c|c|c|}
\hline \multicolumn{2}{|c|}{$\begin{array}{l}\text { Valve or Fitting } \\
\text { ANSI Pressure Classification }\end{array}$} & \multirow{2}{*}{$\begin{array}{c}\text { Schedule No. } \\
\text { of Pipe } \\
\text { Thickness }\end{array}$} \\
\hline Steam Rating & Cold Rating & \\
\hline $\begin{array}{l}\text { 250-Pound and Lower } \\
300-\text { Pound to } 600 \text {-Pound } \\
900-\text { Pound } \\
1500-\text { Pound }\end{array}$ & $\begin{array}{l}500 \text { psig } \\
1440 \text { psig } \\
2160 \text { psig } \\
3600 \text { psig }\end{array}$ & $\begin{array}{l}\text { Schedule } 40 \\
\text { Schedule } 80 \\
\text { Schedule } 120 \\
\text { Schedule } 160\end{array}$ \\
\hline 2500-Pound $\mid \begin{array}{l}1 / 2 \text { to } 6^{\prime} \\
8^{\prime} \text { and larger }\end{array}$ & $\begin{array}{l}6000 \text { psig } \\
3600 \text { psig }\end{array}$ & $\begin{array}{c}\text { xx (Double Extra Strong) } \\
\text { Schedule } 160\end{array}$ \\
\hline
\end{tabular}

* These schedule numbers have been arbitrarily selected only for the purpose of identifying the various pressure classes of valves. and fittings with specific pipe dimensions for the interpretation of flow test data; they should not be construed as a recommendation for installation purposes.

\section{Representative Equivalent Length ${ }^{\ddagger}$ in Pipe Diameters (L/D) Of Various Valves and Fittings}

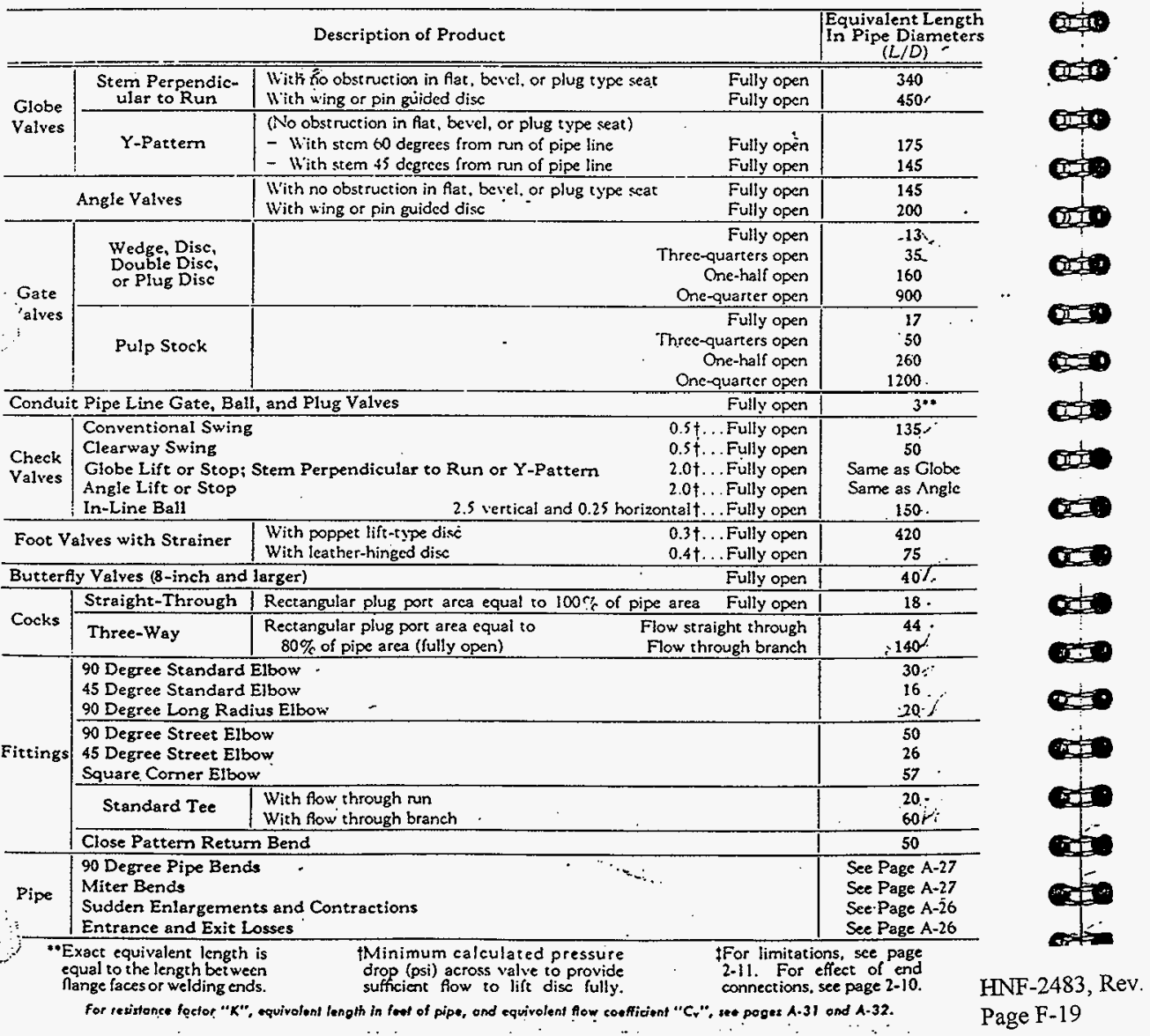


For Complete Turbulence ${ }^{18}$

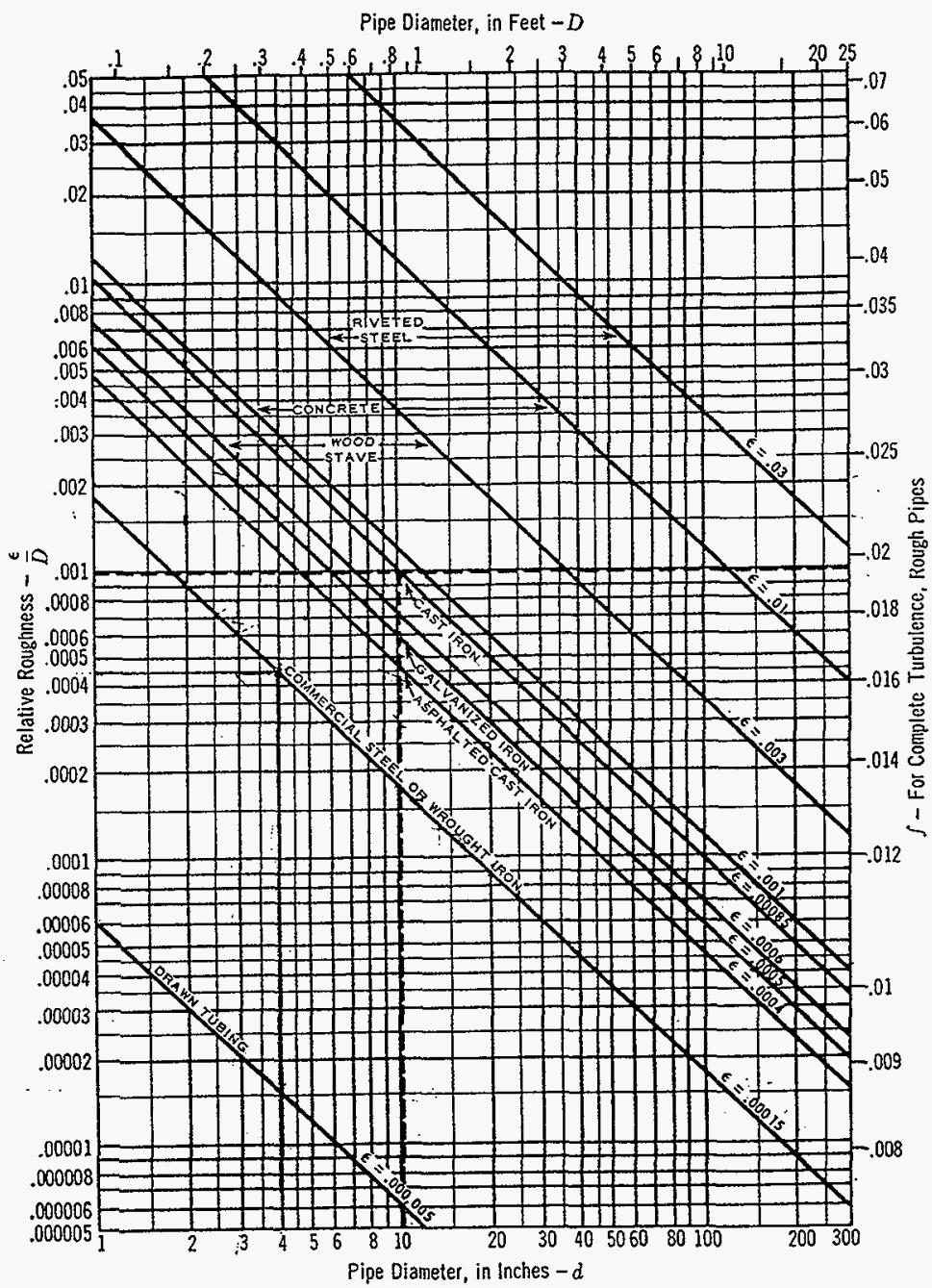

Data extracted from Friction Factors for Pipe Flow by L.F. Moody, with permission of the publisher. The Amcrican Society of Acchanical Engineèr: 29 West 39 th Strcet, New York.
Problem: Determine absolute and relative roughness, and friction factor, for fully turbulent flow in 10-inch cast iron pipe (I.D. $\left.=10.16^{\prime \prime}\right)$.

. Solution : . Absolute roughness $(\epsilon)=0,00085, \ldots$ Relative roughness $(\epsilon / D)=0.001 \ldots$. Friction factor at fully turbulent flow $(f)=0.0106$. 


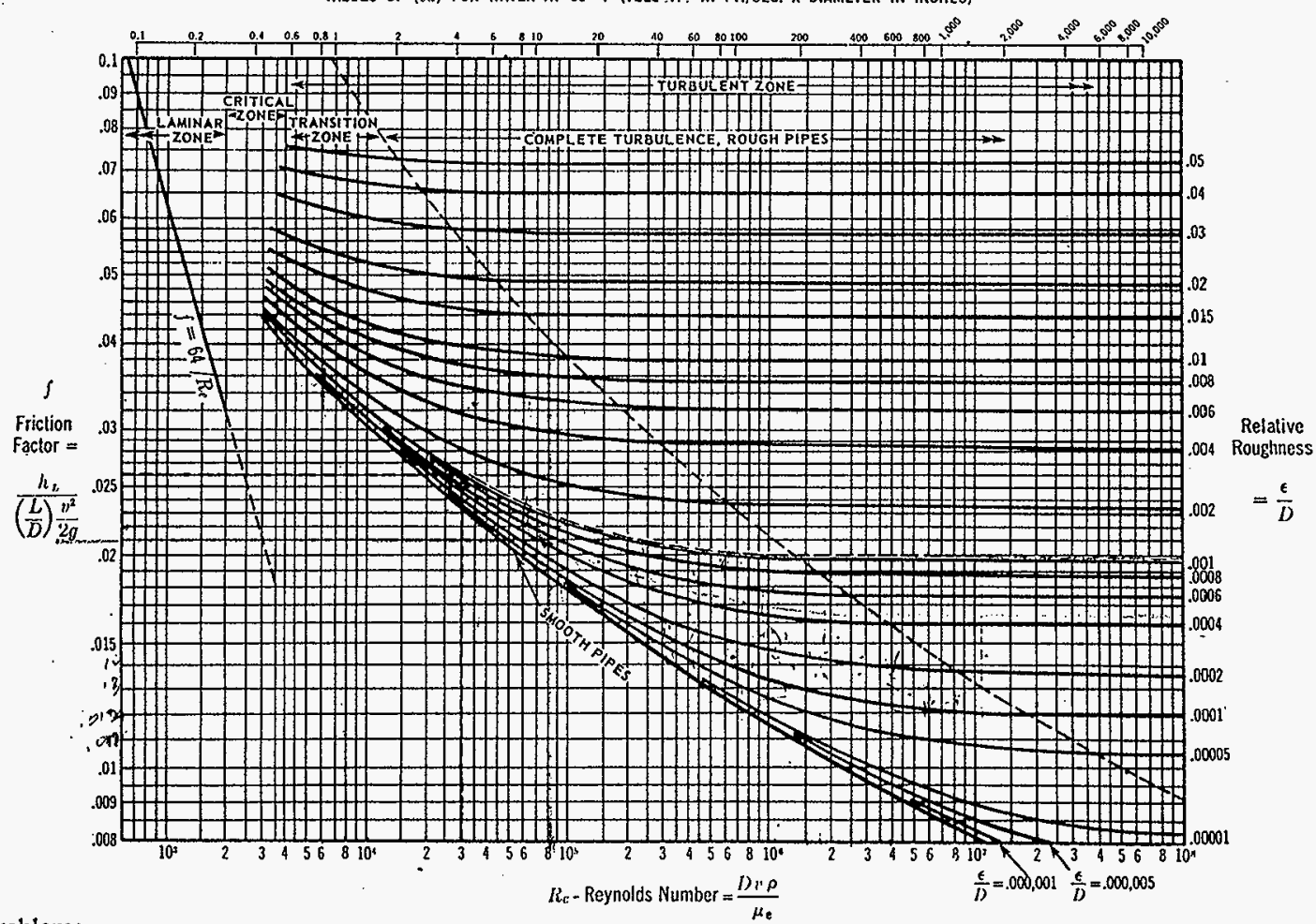

Problem:

Determine the friction factor for 10-inch cast iron pipe (10.16" I.D.) at a Reynolds number flow of 30,000 . Solution: The rclative roughness (see page A-23) is 0.001 . Then, the friction factor $(J)$ equals 0.026 .
For other forms of the $R_{\varepsilon}$ equetion, see page 3-2.

Data extracted from Friction Factors for Pipe Flow by L. F. Moody. with permission of the publisher. The American Society of Mechanical Engincers, 29 West 39 ih Strect. New York 18, N. Y. 
Strainer Codes are formed by using letter code for body, number code for screen specification foltowed by abbreviation for connection required. The code is completed by suffixing the connection size and, for ilanged strainers, the flange rating. An AIFL-6-250 is a $6^{\prime \prime}$ cast Iron strainer with $.045^{\prime \prime}$ perf. stainless steel screen and $250 \mathrm{lb}$. Iianged connections.
Code Meterlal Code Screen

A Gast Iron 30,000 Min. tensile (ASTM A-278 Cl. 30) or equal 1 .045" pert. Stalnless Steel (Type 304)

A Carbon Steel (ASTM A-216 WCB)

C Chrome Moly Steel (1 $1 / 4 \%$ Chrome, $1 / 2 \%$ Moly) ASTM A-217 WC6

D Forged Steel ( $2 \% \%$ Chrome, $1 \%$ Moly) ASTM A- 182 F22

E Stainless Steel Type 316 (ASTM A-35T Grade CFBM)

F Bronze (ASTM B-62)

$4.045^{\prime \prime}$ perforated Brass
$24 \times 110$ Type 316 Mesh Stainless Steel (.0056" opening)

3 045" pertorated Monel

5 $20 \times 20$ Mesh Monel (.034" opening)

$7.045^{\prime \prime}$ perforated Type 316 Stalnless Steel

$8 \mathrm{~V}^{n}$ perforated Type 304 Stainless Steel

$9100 \times 100$ Mesh Stalnless Steel $\left(.0055^{\prime \prime}\right.$ opening)

$X$ Any screen not number coded-specity screen requirement. See Table A-4.
Code Connection

SC Screwed

FL Flanged

SW Socket Weld

BW Butt Wold

Chart A-3-Liquid Flow Capacities for all Armstrong Y.Type Strainers, in U.S. Gallons per minute (gpm).

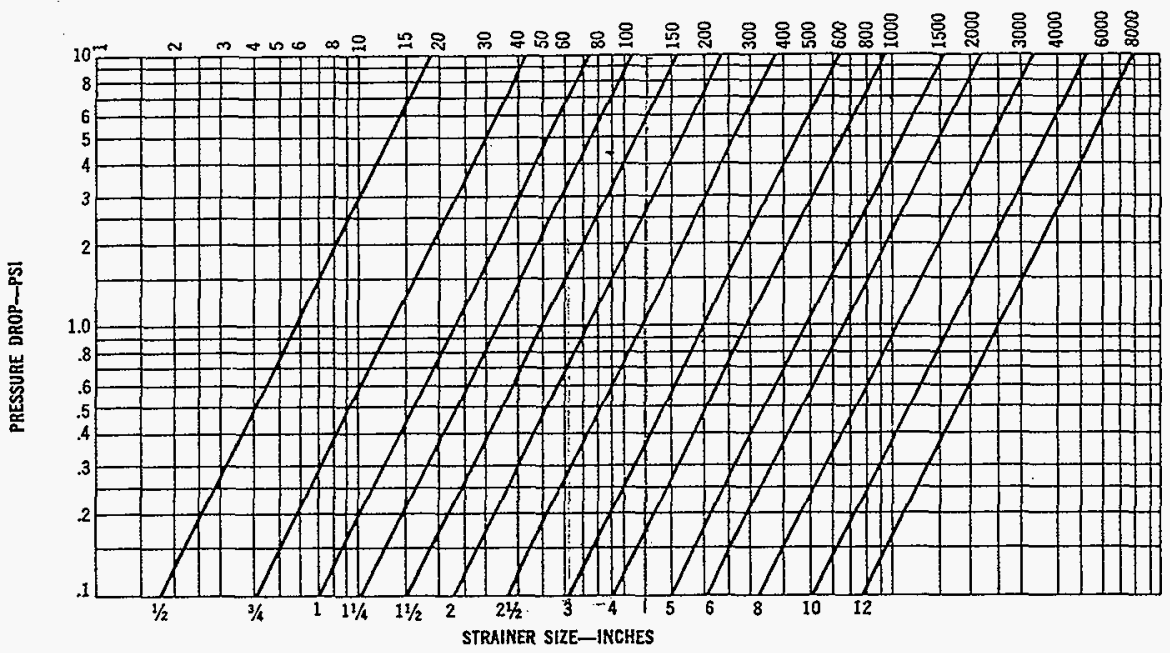

Table B-3-Ratlo of Open Area of Screen to Inside Area of Pipe, Armstrong Y-Type Cast Iron Strainers. Color Background Indlcates that Back-up Screens Are Employed.

\begin{tabular}{|c|c|c|c|c|c|c|c|c|c|c|c|c|c|c|}
\hline \multirow{2}{*}{$\begin{array}{c}\text { Strainer } \\
\text { Size }\end{array}$} & \multirow{2}{*}{$\begin{array}{l}\text { Tọtal } \\
\text { Screen Area, } \\
\text { Sq. in. }\end{array}$} & \multirow{2}{*}{$\begin{array}{l}\text { Inside Rrea } \\
\text { of Pipe, } \\
\text { Sq. in. }\end{array}$} & \multicolumn{7}{|c|}{ RATIO-PERFORATED SCREENS } & \multicolumn{5}{|c|}{ RATIO-WIRE MESH SCREENS } \\
\hline & & & $\mathrm{Ka}^{\prime \prime}$ & $1 / 32 "$ & $.045^{\circ}$ & $1 / 6^{\prime \prime}$ & $1 / x^{\prime \prime}$ & 多" & $1 / 4^{\prime \prime}$ & $24 \times 110$ & 20000 & $40 \times 40$ & $100 \times 100$ & $200 \times 200$ \\
\hline $3 / \pi^{\prime \prime}-1 / 2 "$ & 5.2 & 0.30 & 5.2 & 5.0 & 6.4 & 5.2 & 6.9 & 8.8 & 10.0 & 4.8 & $6 . \overline{6}$ & 5.2 & 22 & 2.5 \\
\hline $3 / 4$ & 7.2 & 0.53 & 4.0 & 3.9 & 5.0 & 4.0 & 5.4 & 6.9 & 7.8 & 3.8 & 5.3 & 4.1 & 1.8 & 2.0 \\
\hline 1" & 11.0 & 0.86 & 3.8 & 3.7 & 4.7 & 3.8 & 5.1 & 6.5 & 7.4 & 3.7 & 5.2 & 4.9 & 1.7 & 19 \\
\hline $14^{\prime \prime}$ & 15.9 & 1.49 & 3.2 & 3.0 & 39 & 3.2 & 4.2 & 5.4 & 6.1 & 32 & 4.4 & 3.4 & 1.5 & 1.6 \\
\hline $11 / 2$ & 23.6 & 2.03 & 3.4 & 3.3 & 4.3 & 3.4 & 4.6 & 59 & 6.7 & 3.5 & 4.8 & $2.8^{\prime}$ & 1.6 & 1.8 \\
\hline$\frac{-12}{2^{2}}$ & 34.4 & 3.35 & 3.0 & 2.9 & 3.8 & 3.0 & 4.1 & 5.2 & 5.9 & 3.2 & 4.4 & 2.6 & $\therefore 1.5$ & 1.6 \\
\hline $21 / 20$ & 54.4 & 4.78 & 3.4 & 3.3 & 42 & 3.4 & 4.5 & 5.8 & 6.6 & 3.3 & 3.5 & 2.7 & 1.7 & 1.9 \\
\hline $3^{n} 125 \div$ & 74 & 7.39 & 1.7 & 2.9 & 3.7 & 3.0 & 4.0 & 5.1 & 5.8 & 2.9 & 3.1 & 2.3 & 1.5 & 1.7 \\
\hline $3^{n} 250 \%$ & 87 & 7.39 & 2.0 & 3.4 & 43 & 3.5 & 4.7 & 6.0 & 6.8 & 3.5 & 3.8 & 2.8 & 1.8 & 2.0 \\
\hline $4^{n} 125 *$ & 123 & 12.7 & 1.7 & 2.8 & 3.5 & 2.9 & 3.8 & 4.9 & 5.6 & 2.8 & 3.0 & 2.3 & 1.5 & 1.6 \\
\hline $4^{\prime \prime} 250 *$ & 145 & 12.7 & 2.0 & 3.3 & 42 & 3.4 & 4.5 & 5.8 & 6.6 & 3.4 & 3.7 & 2.1 & 1.8 & 2,0 \\
\hline $5^{\prime \prime} 125$ & 194 & 20.0 & 1.7 & 2.8 & 35 & 2.9 & 3.8 & 4.9 & 5.6 & 1.7 & 3.1 & 1.8 & 1.5 & 1.7 \\
\hline $5^{\prime \prime} 250 \%$ & 245 & 20.0 & 2.1 & 3.5 & 4.5 & 3.6 & 4.3 & 6.2 & 7.1 & 2.2 & 4.0 & 2.3 & 2.0 & 2.2 \\
\hline $6^{\prime \prime} 125$ & 272 & 28.9 & 1.6 & 2.7 & 3.4 & 2.8 & 3.1 & 4.8 & 5.4 & 1.6 & 3.0 & 1.8 & 1.5 & 1.6 \\
\hline $6^{\prime \prime} 250$ 毒 & 317 & 28.9 & 1.9 & 3.1 & 4.0 & 3.2 & 4.3 & 5.5 & 6.3 & $\cdot 1.9$ & 2.7 & 2.1 & 1.7 & 19 \\
\hline $8^{\prime \prime} 125 *$ & 464 & 50.0 & 1.6 & 2.6 & 3.4 & 2.7 & 3.7 & 4.7 & 5.3 & 1.6 & 2.3 & 1.8 & 1.5 & 1,7 \\
\hline $8^{4} 250 \div$ & 550 & 50.0 & & 3.1 & 4.0 & 3.3 & 4.4 & 5.6 & 6.3 & $\therefore-2.0$ & .2 .8 & $2.1-1$ & 1.8 & 2.0 \\
\hline $10^{n-1257}$ & 733 & 78.8 & 1.6 & 2.7 & 3.4 & 2.7 & 3.7 & 4.7 & 5.4 & $\therefore 1.7$ & 2.3 & 1.8 & 1.5 & 1.7 \\
\hline $12^{\prime \prime} 125 \%$ & 1050 & 113.1 & 1.6 & 2.6 & 34 & 2.7 & 3.7 & 4.7 & 5.3 & 1.7 & 2.3 & 18 & 1.5 & 1.7 \\
\hline \multicolumn{3}{|c|}{ Percentage Open Area } & $30 \% *$ & $29 \%$ & $37 \%$ & $30 \%$ & $40 \%$ & $51 \%$ & $58 \%$ & $33.3 \%$ & $46.2 \%$ & $36 \%$ & & \\
\hline
\end{tabular}

Hotes; Gast steet strainers have the same rattos as $250 \mathrm{lb}$. cast lton except for $150 \mathrm{bb}$. stainless steel which is the same as $125 \mathrm{lb}$. east lron.

This table does not apply lo forged steel strainers in table 0-7. 


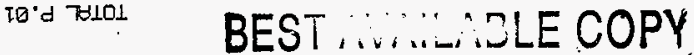

Performance Adjustment Factors

Tablo 3-1 - Parlontranci Dita Adlutenem Fators (a)

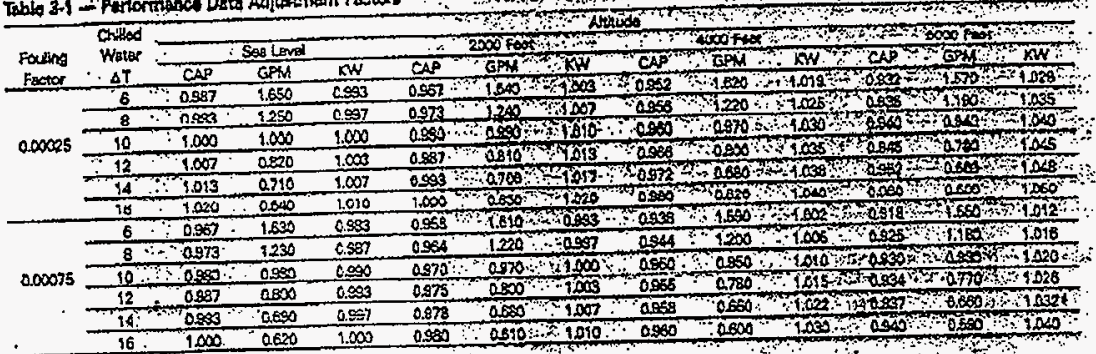

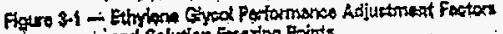
and solution fividing Points

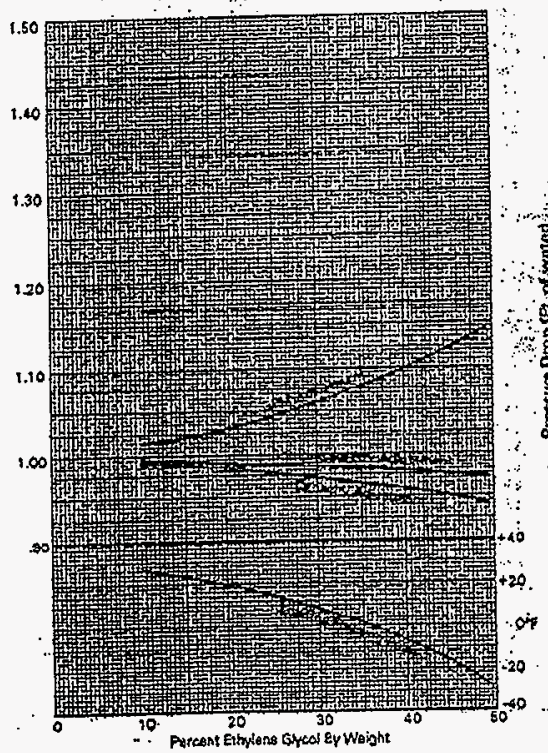

Tabls $3-2$ - Ethitane Chycal Prossure Drop Adiutinarte Fortor

\begin{tabular}{|c|c|c|c|c|c|c|}
\hline \multirow[b]{2}{*}{ LWt } & \multicolumn{6}{|c|}{ Freard Or Euhveno Gyed } \\
\hline & 0 & 10 & 20 & 30 & 40 & BO \\
\hline 0 & 1.15 & 1.22 & 130 & 138 & 145 & 1.55 \\
\hline 10 & 9.12 & 1.19 & 1.26 & 134 & 1.42 & 1.51 \\
\hline 20 & 1000 & 0.15 & 122 & 9.30 & 1.90 & 1,47 \\
\hline 30 & 1.06 & 1.12 & 1.19 & 126 & 1.34 & 1.43 \\
\hline 40 & 103 & 100 & $\$ .16$ & 3.23 & 130 & 1.36 \\
\hline 49 & 1.00 & 108 & 0.13 & 1.20 & 1.27 & 1.35 \\
\hline
\end{tabular}

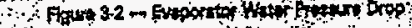

$\therefore$ : : An For

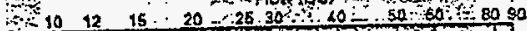

$6^{2} \longrightarrow 1_{1211}^{150}$

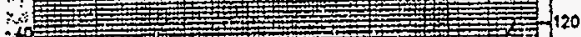

$30 \longrightarrow 212$

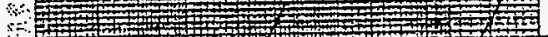

$30 \quad 2 \quad 190$

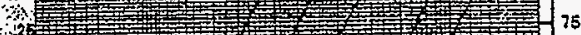

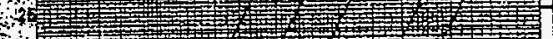

$12+212$

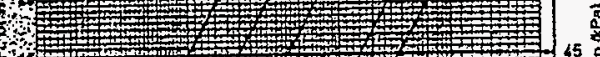

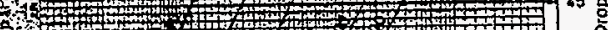

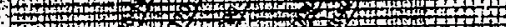

EF

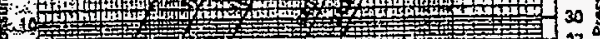

6092727

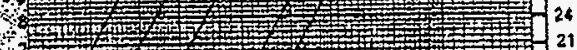

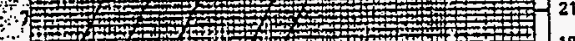

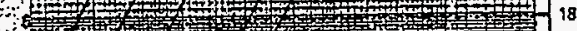

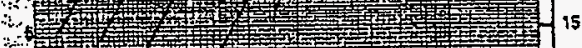

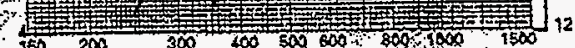

$$
\text { 150 } 200 \quad 300 \text { Flow (GPM) }
$$

弯

and 
THERMAL EXPANSION OF PIPE IN INCHES PER 100 FEET

\begin{tabular}{|c|c|c|c|c|c|c|c|c|c|}
\hline $\begin{array}{c}\text { Pressure } \\
\text { Psig }\end{array}$ & $\begin{array}{l}\text { Temp. } \\
\text { Degrees } \\
\text { Fahr. }\end{array}$ & $\begin{array}{l}\text { Steel } \\
\text { Pipe }\end{array}$ & $\begin{array}{l}\text { Stainless } \\
\text { Steel } \\
18 \mathrm{CR}-8 \mathrm{NI}\end{array}$ & $\begin{array}{c}\text { Copper } \\
\text { Pipe }\end{array}$ & $\begin{array}{c}\text { Pressure } \\
\text { Psig }\end{array}$ & $\begin{array}{c}\text { Temp. } \\
\text { Degrees } \\
\text { Fabr. }\end{array}$ & $\begin{array}{l}\text { Steel } \\
\text { Pipe }\end{array}$ & $\begin{array}{l}\text { Stainjess } \\
\text { Steel } \\
\text { 18CR-8NI }\end{array}$ & $\begin{array}{c}\text { Copper } \\
\text { Pipe }\end{array}$ \\
\hline & -20 & 0 & 0 & 0 & 135 & 358 & 3.012 & 4.3272 & 4.356 \\
\hline & 0 & 0.145 & .2157 & 0.204 & 140 & 361 & 3.038 & 4.3632 & 4.381 \\
\hline & 20 & 0.293 & .4331 & 0.442 & 145 & 364 & 3.065 & 4.3992 & 4.430 \\
\hline & $\longrightarrow 40$ & 0.430 & .6522 & 0.655 & 150 & 366 & 3.084 & 4.4232 & 4.454 \\
\hline & 50 & 0.512 & .7623 & 0.772 & 175 & 377 & 3.188 & 4.5555 & 4.595 \\
\hline & 60 & 0.593 & .8729 & 0.888 & 180.9 & 380 & 3.211 & 4.5917 & 4.628 \\
\hline & 80 & 0.725 & 1.0953 & 1.110 & 200 & 387 & 3.272 & 4.6761 & 4.718 \\
\hline & 100 & 0.898 & 1.3195 & 1.338 & 232.4 & 400 & 3.375 & 4.8334 & 4.870 \\
\hline & 120 & 1.055 & 1.5454 & 1.570 & 250 & 406 & 3.435 & 4.9058 & 4.941 \\
\hline & 140 & 1.209 & 1.7729 & 1.794 & 293.7 & 420 & 3.566 & 5.0751 & 5.118 \\
\hline & 160 & 1.368 & 2.0022 & 2.008 & 366.1 & 440 & 3.740 & 5.3178 & 5.358 \\
\hline & 180 & 1.528 & 2.2331 & 2.255 & 451.3 & 460 & 3.929 & 5.5619 & 5.612 \\
\hline & 200 & 1.691 & 2.4658 & 2.500 & 550.3 & 480 & 4.100 & 5.8068 & 5.855 \\
\hline 2.5 & 220 & 1.852 & 26974 & 2.720 & 664.3 & 500 & 4.296 & 6.0528 & 6.110 \\
\hline 5 & 227 & 1.910 & 2.7788 & 2.804 & 795.3 & 520 & 4.487 & 6.3012 & 6.352 \\
\hline 10 & 239 & 2.010 & 2.9186 & 2.828 & 945.3 & 540 & 4.670 & 6.5507 & 6.614 \\
\hline 15 & 250 & 2.101 & 3.0472 & 3.075 & 1115.3 & 560 & 4.860 & 6.8013 & 6.850 \\
\hline 20 & 260 & 2.183 & 3.1645 & 3.189 & 1308.3 & 580 & 5.051 & 7.0531 & 7.123 \\
\hline 25 & 266 & 2.213 & 3.2349 & 3.259 & 1525.3 & 600 & 5.247 & 7.3061 & 7.388 \\
\hline 30 & 274 & 2.299 & 3.3291 & 3.352 & 1768.3 & 620 & 5.437 & 7.5571 & 7.636 \\
\hline 35 & 280 & 2.350 & 3.3998 & 3.422 & 2041.3 & 640 & 5.627 & 7.8091 & 7.893 \\
\hline 40 & 286 & 2.401 & 3.4707 & 3.509 & 2346.3 & 660 & 5.831 & 8.0621 & 8.153 \\
\hline 45 & 292 & 2.451 & 3.5417 & 3.576 & 2705 & 680 & 6.020 & 8.3160 & 8.400 \\
\hline 50 & 297 & 2.494 & 3.6009 & 3.632 & 3080 & 700 & 6.229 & 8.5709 & 8.675 \\
\hline 55 & 302 & 2.536 & 3.6601 & 3.689 & & 720 & 6.425 & 8.8320 & 8.912 \\
\hline 60 & 307 & 2.579 & 3.7193 & 3.747 & & 740 & 6.635 & 9.0945 & 9.203 \\
\hline 65 & 312 & 2.622 & 3.7786 & 3.806 & & 760 & 6.833 & 9.3581 & 9.460 \\
\hline 70 & 316 & 2.656 & 3.8261 & 3.853 & & 780 & 7.046 & 9.6231 & 9.736 \\
\hline 75 & 320 & 2.690 & 3.8736 & 3.900 & & 800 & 7.250 & 9.8892 & 9.992 \\
\hline 80 & 324 & 2.724 & 3.9211 & 3.949 & & 820 & 7.464 & 10.1526 & 10.272 \\
\hline 85 & 328 & 2.759 & 3.9687 & 3.998 & & 840 & 7.662 & 10.4170 & 10.512 \\
\hline 90 & 331 & 2.784 & 4.0044 & 4.035 & & 860 & 7.888 & 10.6825 & 10.814 \\
\hline 95 & 335 & 2.805 & 4.0521 & 4.084 & & 880 & 8.098 & 10.9490 & 11.175 \\
\hline 100 & 338 & 2.845 & 4.0879 & 4.121 & & 900 & 8.313 & 11.2166 & 11.360 \\
\hline 105 & 341 & 2.870 & 4.1238 & 4.169 & & 920 & 8.545 & 11.4898 & 11.625 \\
\hline 110 & 344 & 2.895 & 4.1596 & 4.192 & & 940 & 8.755 & 11.7642 & 11.911 \\
\hline 115 & 347 & 2.920 & 4.1954 & 4.227 & & 960 & 8.975 & 12.0399 & 12.180 \\
\hline 120 & 350 & 2.946 & 4.2313 & 4.263 & & 980 & 9.196 & 12.3168 & 12.473 \\
\hline 125 & 353 & 2.971 & 4.2672 & 4.298 & & 1000 & 9.421 & 12.5950 & 12.747 \\
\hline 130 & 355 & 2.987 & 4.2912 & 4.321 & & & & & \\
\hline
\end{tabular}

TYPICAL, INSULATION THICKNESSES

\begin{tabular}{|c|c|c|c|}
\hline Temperature Ranges & Pipes * $^{\prime \prime}$ "thru 3 & Pipes 4" thru 6" & Pipes 8" thru 12" \\
\hline $100^{\circ} \mathrm{F}$ thru $200^{\circ} \mathrm{F}$ & $1^{\prime \prime}$ & $1 "$ & $11 / 2 "$ \\
\hline $200^{\circ} \mathrm{F}$ thru $300^{\circ} \mathrm{F}$ & $1 "$ & $1 y_{2} "$ & 2" \\
\hline $300^{\circ} \mathrm{F}$ thru $400^{\circ} \mathrm{F}$ & $11 / 2 "$ & $21 / 2 "$ & $3 "$ \\
\hline $400^{\circ} \mathrm{F}$ thru $600^{\circ} \mathrm{F}$ & $2^{\prime \prime}$ & 3" & $3 \% "$ \\
\hline
\end{tabular}

HNF-2483, Rev. 0

Page F-24 


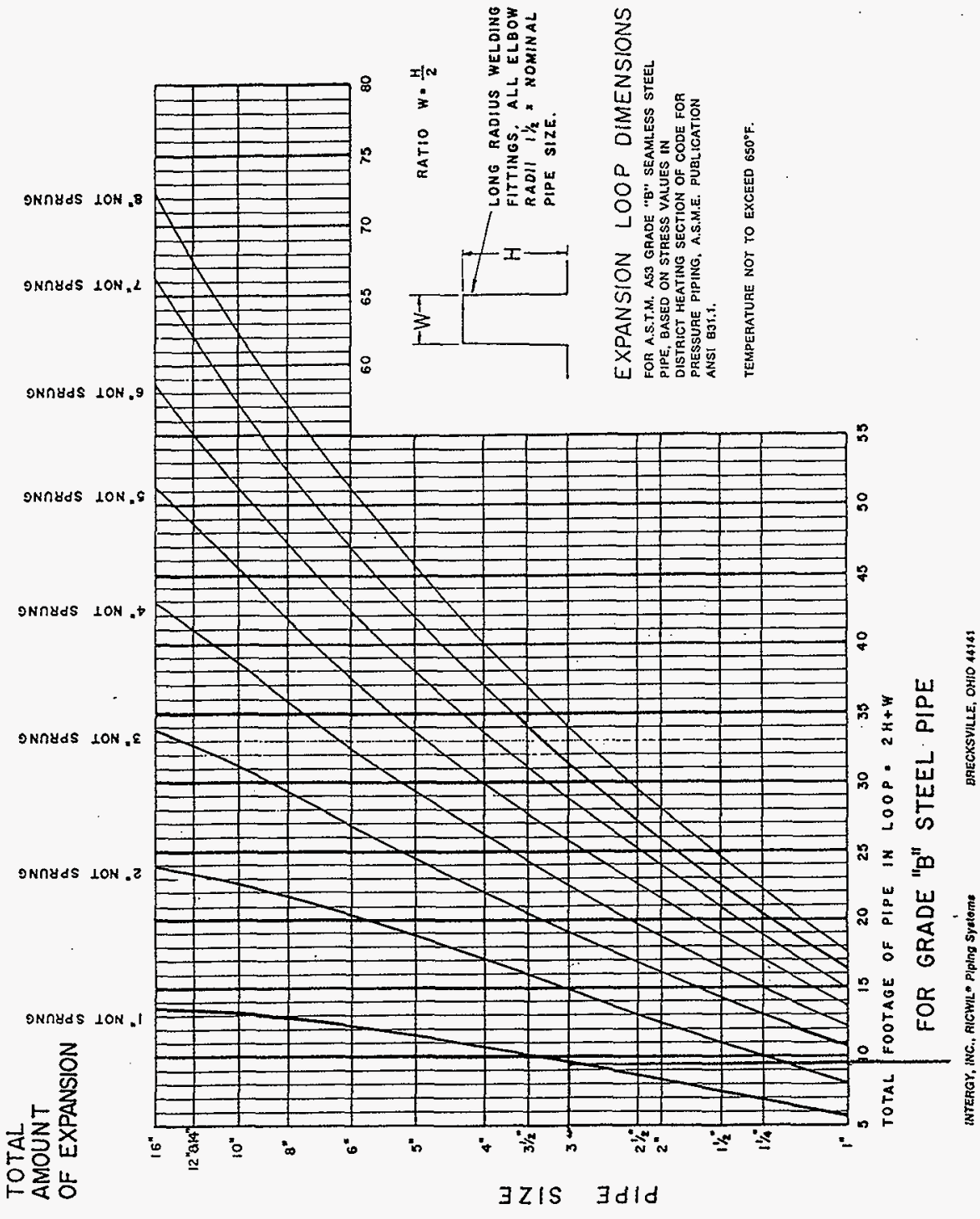

HNF-2483, Rev. 0

Page F-25 
POWER MACHINE CO.

EAX TRANSMITTF

HNF-2483, Rev. 0 Page F-26

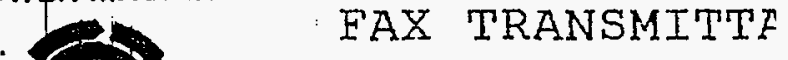

COMPMESSORS, PUIMPS ARD DRIVES - ENGINEERED SYSTEMS KIPARY, INC. EXPORT TRANSACTIONS

TO:

zOSS

DATE: $\quad 3-28-94$

FAX LOG No: $94 / 408$

COMPANY IEC KAISER ELX.

EAX NO:

$510-419-15355$

SUBJECT :

FROM: TEYDAN KAOEMAN

No. Of PAGES Z INC:UDING COVIR SEEET REPLY TO FAX (510) 547-2007

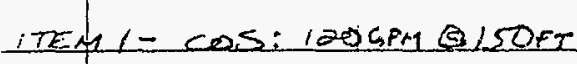

ONE (1) EACH WOEKSOLL DRESSTR PUMP MODEL $3 \times 1.5 \times 65+0 \times$

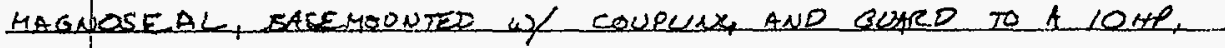
S6OOREM NOTOR. (56\% EFELCANOK)

BULKET PRICE EACHT \$ $6,000, \infty$

IEN 2- COS: $120 \mathrm{GPM} Q 107 \mathrm{FT}$

ONE $(1)$ WGERSOLL DEESER FUME MODEL $3 \times 1.5 \times 6$ SHDX

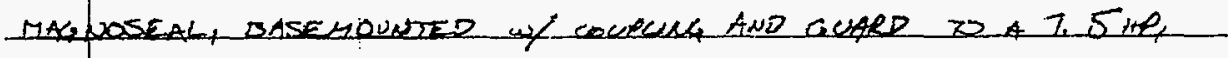
ZWOA RPI MOTOR ( $58 \%$ EFFICIALCY)

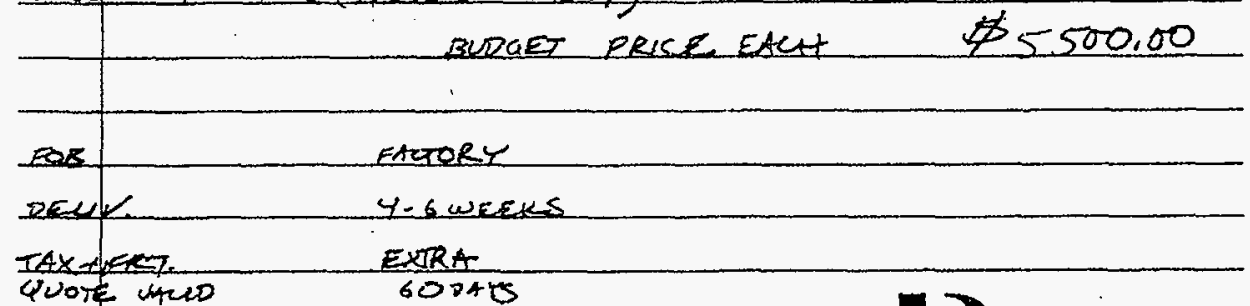

INGERSOLLAAND.

AIRCOMPRESSORS

\section{ingersoll-Dresser. Pumps}

5768 SHELLMOUND STAEET - EMERYVILLE, CALIFORNIA 94608 - (510) 658-9661 - FAX (510) 547-2007

151 Bernal Road, Suite SA, San Jose, California $\$ 5119$ (408) 365-8700 . FAX (408) 365-0404

4003 Seaport Blvo. West Sacramento, Calíornia 95691 (916) 375-0075 . FAX (916) 375-8524 
DON'T SAY IT --- Write It!

TO: W.J. McGinley
DATE: January 7, 1994

FROM: Peter H. Langowski

Telephone: (509) $376-4226$

cc (w/o att.): Ron Davidson, David Shrimpton, John Jurgilewicz, Charlie O'Neill

SUBJECT: Project W-320 Chiller Specification \& Design Input

Please accept the following as the input you requested from $\mathrm{KEH}$ under Article I.B. of your Work Plan dated 12/30/93.

1. Length of coolant pipe between the chiller skid and condenser.

Per HVAC Overall C-Farm Site Plan H-2-818469, revision 0 dated 1/7/94 (attached). A takeoff of this drawing yields the following (pipe lengths indicated for each supply line and return line; i.e. the total length of piping in the system is $638 \mathrm{feet}$ ):

279 feet of pipe below grade (near horizontal)

' 6 feet of pipe below grade (vertical risers)

+34 feet of pipe above grade (total of both the condenser and the chiller ends) 319 feet total for each supply and return

2. Number of elbows, (long or short radius).

All chilled water piping elbows should be long radius $(r / D=1.5)$. For sizing purposes use 14 elbows for each supply and return (i.e. 28 total elbows in the system between the condenser and the chiller skid): $8 @ 900$; and $6 @ 450$.

3. Heat transfer to coolant, Btu/hr.

The Energy Balance drawing H-2-818479 states the heat transfer as being 235,080 $\mathrm{Btu} / \mathrm{h}$. Condenser sizing has been completed at $250,000 \mathrm{Btu} / \mathrm{h}$. Use $250,000 \mathrm{Btu} / \mathrm{h}$ for calculation purposes.

4. Coolant temperature entering and leaving condenser.

Based on a preliminary selection of a condenser, the entering and leaving condenser temperatures shall be $33 \circ \mathrm{F}$ and $38 \mathrm{OF}$, respectively. Preliminary coolant flow pressure drop through the condenser is $3 \mathrm{psig}$ based on $120 \mathrm{gpm}$ of $40 \%$ propylene glycol solution.

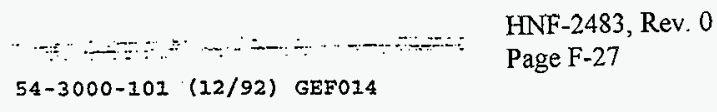




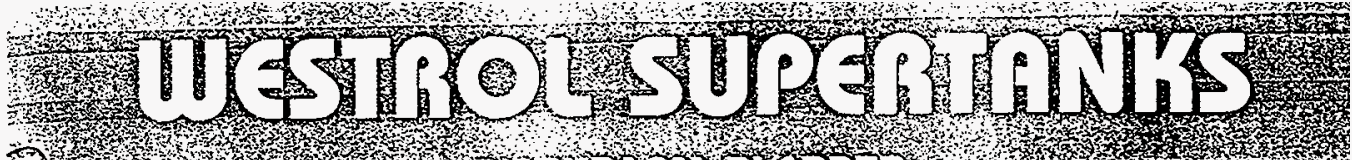
(5)

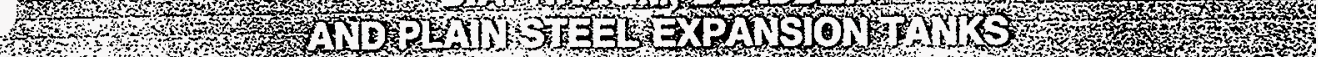

$n$
3

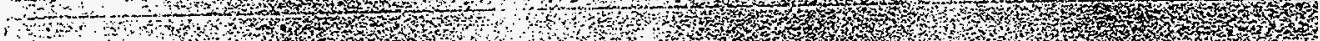

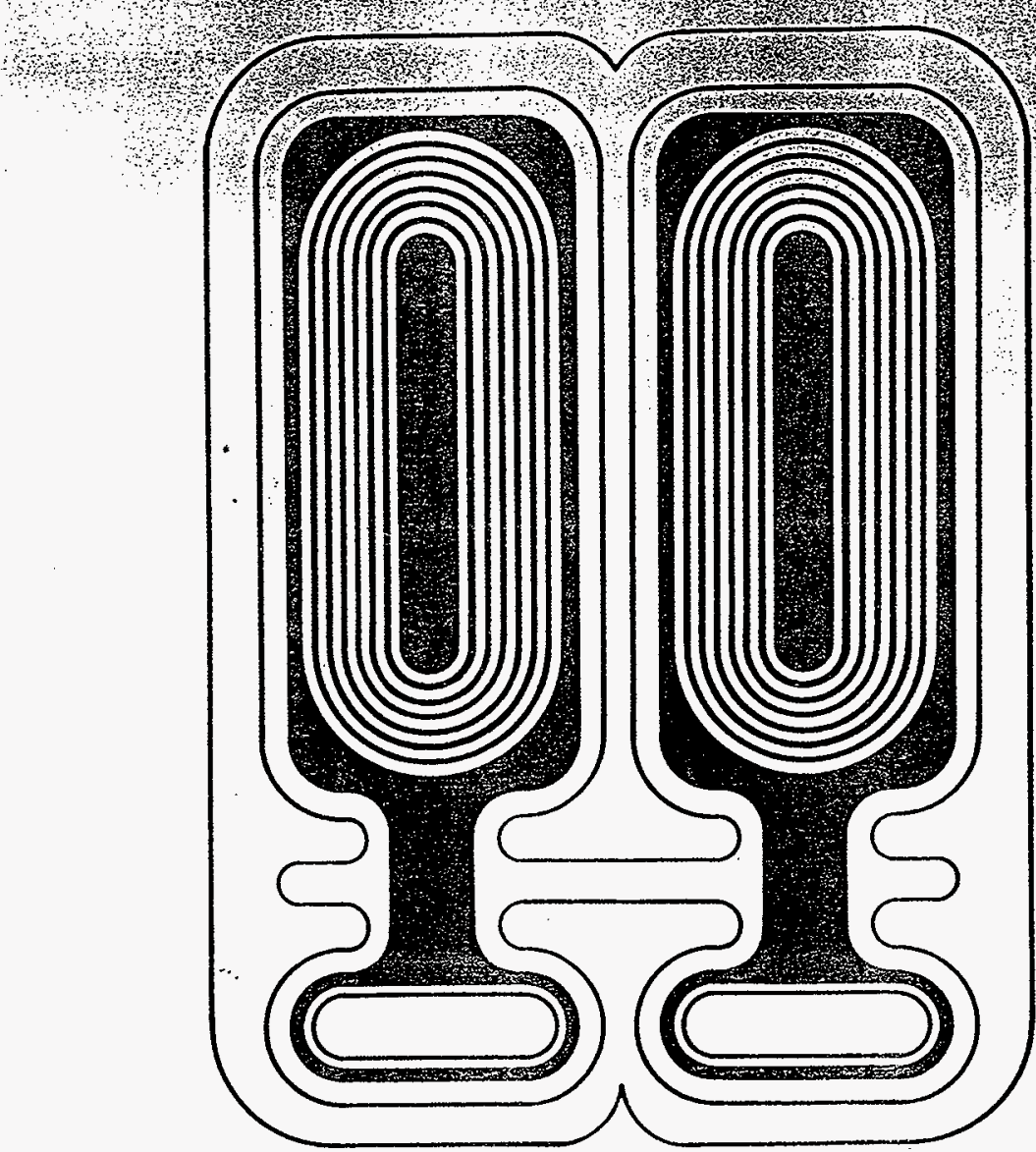

HNF-2483, Rev. 0 Page F-28

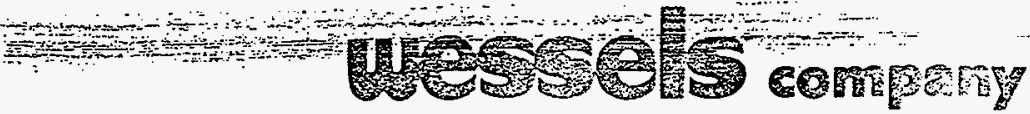


IVIGy'Hoche

SHOC \& SGRP PROCESS PUMPS

CAPABULITIES OF SHOC/SGRP ANSI PROCESS PUMPS

\begin{tabular}{|c|c|c|}
\hline Viecouth & (Mex): & $\begin{array}{l}600 \text { Cenlippisie } \\
2500 \mathrm{sSU}\end{array}$ \\
\hline Tomper & (M: (Mx): & $\begin{array}{l}250 \text { Deg. F tor SGRP } \\
250 \text { Dog. F. for PtOeess SHOC } \\
500 \text { Deg. F. tor Al Metal SHOC }\end{array}$ \\
\hline Working & Hesourt: & 375 psig max. \\
\hline Entrain: & $\operatorname{Cos}(\operatorname{Max})$ & $3 \%$ max. by volume \\
\hline Faticlos & (Mux): & $\begin{array}{l}100 \text { Micron, } 1.5 \% \text { by weight } \\
\text { Contact SPD lor Wash Flow } \\
\text { Strainar Application }\end{array}$ \\
\hline Minimun & Flow: & Ses Back of pape \$100.20, sheel 101 \\
\hline
\end{tabular}

PRESSURE LIMITS, PS:

Rster 10 P. ssure vs. Temperature charts below to determine pressure jimits tor speclfic opera'ing conditions. The Maximum Stelicn Fressure equals the Maximulm Working Presbure minus the Diffenential Pressivie.

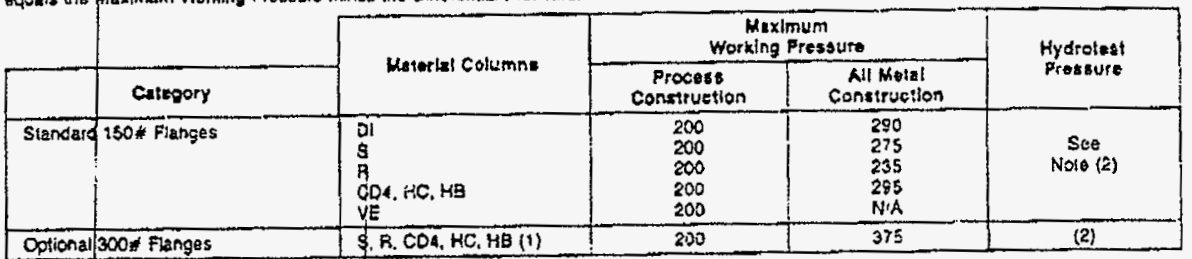

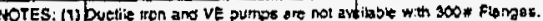

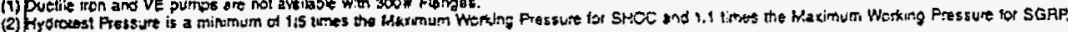

\section{PRESSURE VS. TEMPERATURE}
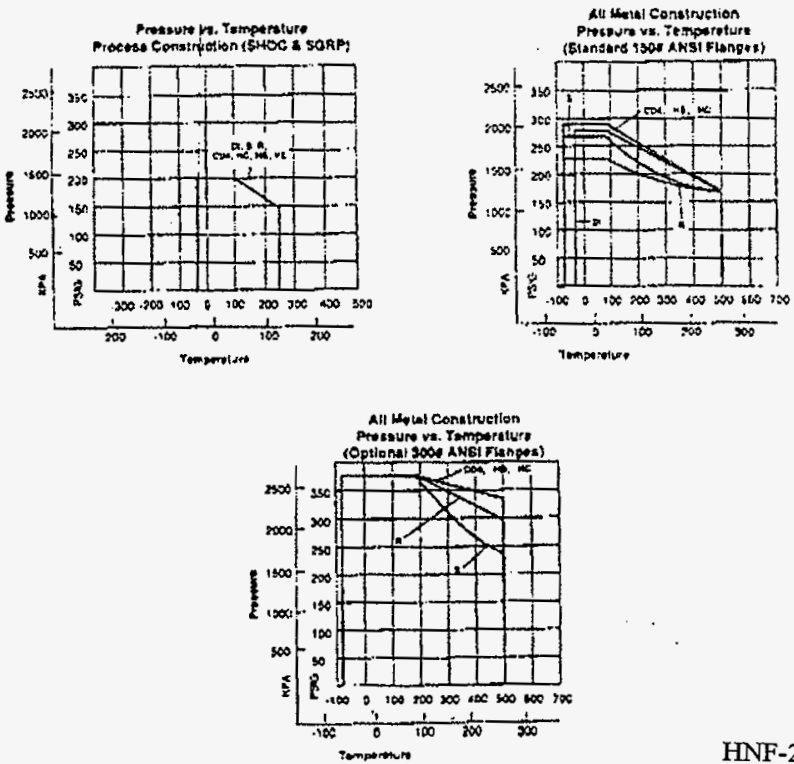

HNF-2483, Rev. 0

Page F-31 


\section{Magnoseal}

\section{SHOC \& SGRP PROCESS PUMPS}

HNF-2483, Rev. 0

STANDARO CONSTRUCTION

\begin{tabular}{|c|c|c|c|c|c|}
\hline Catogo & $y$ & & Construction Festures & Stendard & $\begin{array}{l}\text { Opilonal } \\
\text { At Extra Frlet }\end{array}$ \\
\hline Type & & \multicolumn{2}{|c|}{ 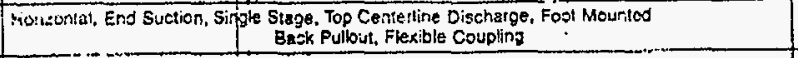 } & $x$ & \\
\hline Orive & & \multicolumn{2}{|c|}{ Fermanent High Strength Misgnel-10-Magnet } & $x$ & \\
\hline Rotainan & & \multicolumn{2}{|c|}{ CW (Clockwise) facirg fump coupling iper Hydrautic hstitule) } & $x$ & \\
\hline Casing & & \multicolumn{2}{|c|}{ SHOC \& SGRP are interch chgeabie wils HOC2 \& GFP respectively } & $x$ & \\
\hline Notzles & & \multicolumn{2}{|c|}{ 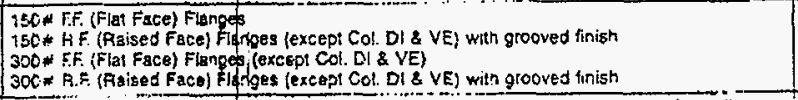 } & $x$ & $\begin{array}{l}x \\
x \\
x\end{array}$ \\
\hline $\begin{array}{l}\text { Auxilist y } \\
\text { Corinecilo } \\
\text { Cesing }\end{array}$ & 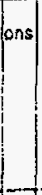 & \multicolumn{2}{|c|}{ 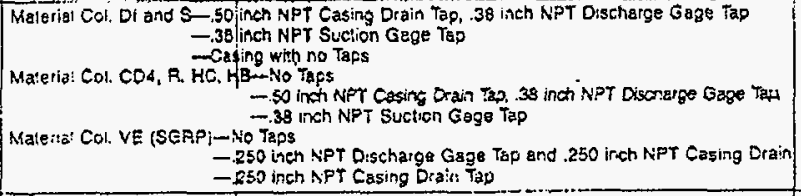 } & $x$ & $\begin{array}{l}x \\
\dot{x} \\
x \\
x \\
x \\
x\end{array}$ \\
\hline Prain & & \multicolumn{2}{|c|}{$\begin{array}{l}\text { Machuned Moad Plug-Col. Dl and s } \\
\text { Square Head Polypro-ColivE } \\
\text { Machuned Heed Plug-Col.COA, R, MC. wts } \\
\text { Rourd Head Plug }\end{array}$} & $x$ & $\begin{array}{l}x \\
x \\
x\end{array}$ \\
\hline impelter & & \multicolumn{2}{|c|}{$\begin{array}{l}\text { Serri-Open, Balanced (1) SHOC \& SGRP (except for } 9-1 / 2 \times 1 \times 9 \text { SGRP) are interchengeable } \\
\text { with HOC2 \& GRP respectively }\end{array}$} & $x$ & \\
\hline Cover & & \multicolumn{2}{|c|}{ 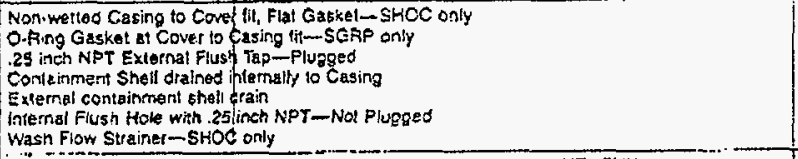 } & $\begin{array}{l}x \\
x \\
x \\
x \\
x\end{array}$ & $\begin{array}{l}x \\
x\end{array}$ \\
\hline $\begin{array}{c}\text { Geskets } \\
0 . F_{i i g}\end{array}$ & & $\begin{array}{l}\text { Gaskals-SkOC only } \\
\text { (Group } 2 \text { includes casing and } \\
\text { containiment shell gaskets) } \\
\text { Containment Sheli O-Ring-SHOC } \\
\text { (Groug il } \\
\text { O.Ping-SGRP } \\
\text { (irtudes all O-Rings) }\end{array}$ & $\begin{array}{l}\text { - NTLSYN } \\
\text { - Totion } \\
\text { - Graphite } \\
\text { - Vitor:A } \\
\text { - Kairez } \\
\text { - Alitas } \\
\text { - VitonoA } \\
\text { - Aflas }\end{array}$ & $x$ & $\begin{array}{l}x \\
x \\
x \\
x \\
x\end{array}$ \\
\hline $\begin{array}{l}\text { Bepring } \\
\text { Housing }\end{array}$ & & \multicolumn{2}{|c|}{ 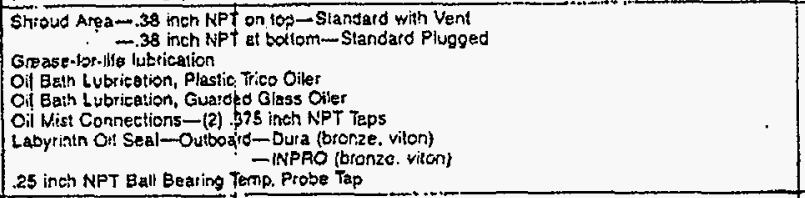 } & $\begin{array}{l}x \\
x \\
x\end{array}$ & $\begin{array}{l}x \\
x \\
x \\
x \\
x \\
x\end{array}$ \\
\hline Couping & & \multicolumn{2}{|c|}{ All Menulactuters and Typeb } & & $\mathrm{x}$ \\
\hline $\begin{array}{l}\text { Coupling } \\
\text { Guard }\end{array}$ & & \multicolumn{2}{|l|}{$\begin{array}{l}\text { OSHA. Się } \\
\text { Nan-Sparking Aluminum }\end{array}$} & & $\begin{array}{l}x \\
x \\
\end{array}$ \\
\hline Bedplat & & \multicolumn{2}{|l|}{$\begin{array}{l}\text { Fabricated Steel } \\
\text { with } 31655 \text { Drp Pan } \\
\text { whin Mrip Lip } \\
\text { with Machined Pads } \\
\text { with Stainless steol Stits. } \\
\text { Fibeiglass with butt+in Drip' Pen } \\
\text { with Stainless Steal Stits }\end{array}$} & & $\begin{array}{l}x \\
x \\
x \\
x \\
x \\
x \\
x\end{array}$ \\
\hline Testing & & \multicolumn{2}{|l|}{$\begin{array}{l}\text { Hyolostatie Test } \\
\text { P\&rformanee Test } \\
\text { NPSH Test } \\
\text { Witness Tests }\end{array}$} & $x$ & $\begin{array}{l}x \\
x \\
x\end{array}$ \\
\hline
\end{tabular}

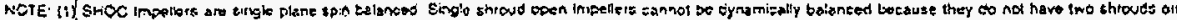

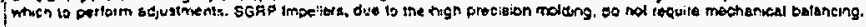




\section{Magnoseal" \\ SHOC \& SGRP PROCESS PUMPS}

FNF-2483, Rev. 0

Page F-33

\section{STANDARD MATERIALS \\ ALL METAL CONSTRUCTION SHOC ONLY}

\begin{tabular}{|c|c|c|c|c|c|c|c|}
\hline & Haterlal Cefumn & 이 & $\mathbf{s}$ & $\mathrm{CO} 4$ & $R$ & $\mathrm{HC}$ & HE \\
\hline & Genersi Descrlption & Ductile lion & 316 S.S. & CD4kCu & Alloy 20 & He sielloy C & Hustelloy E \\
\hline Cesing & & $\begin{array}{c}\text { Ouctile fron } \\
\text { (Hole 1) }\end{array}$ & 3:6 S.S. (Cast) & CoAMCu & Alloy 20 (Casi) & Hesteiloy C & Hastelloy $B$ \\
\hline \multicolumn{2}{|c|}{ Casing Casket } & \multicolumn{6}{|c|}{ Non'Asbeslos } \\
\hline \multicolumn{2}{|c|}{ Casing Eolting } & $\begin{array}{c}\text { Carbon Steet } \\
\text { (Boting) }\end{array}$ & & & \multicolumn{2}{|l|}{$\begin{array}{l}304 \text { S S } \\
\text { (Boling) }\end{array}$} & \\
\hline impeiler & & $\begin{array}{l}\text { Carbon Siesl } \\
\text { (Casi) }\end{array}$ & $\begin{array}{c}316 \text { S.S. } \\
\text { (C251) }\end{array}$ & CO4MiCu & $\begin{array}{l}\text { Ailoy } 20 \\
\text { (Cast) }\end{array}$ & Hasteiloy C & Mastelloy 3 \\
\hline \multicolumn{2}{|c|}{ Casing Govel } & & $\begin{array}{c}31655 \\
\text { (C) } 35:)\end{array}$ & & $\begin{array}{c}\text { Alloy } 20 \\
\text { (Cost) (Nole 2) }\end{array}$ & Hastelloy C & Hastelioy $B$ \\
\hline \multicolumn{2}{|c|}{ Shalt-putno (intorne) } & & $316 \$ \$$. & & Alloy 20 & fisstelloy C & Kasteticy 8 \\
\hline \multicolumn{2}{|c|}{ Shaft-Bto Hag (sxiemsl) } & \multicolumn{6}{|c|}{ Carbon Sicel ithot Foted } \\
\hline \multicolumn{2}{|c|}{ Inner Mágnet Carrizr } & & 3164 S S. & & Alloy 20 & Haslelioy C & Hastetioy B \\
\hline \multicolumn{2}{|c|}{ Duter Magnat Carrier (1) } & \multicolumn{6}{|c|}{ Ductie tion } \\
\hline \multicolumn{2}{|c|}{ Containpeni Shell } & \multicolumn{4}{|c|}{ Haslelloy (3) } & Hasielloy C & Hasiolloy $B$ \\
\hline \multicolumn{2}{|c|}{ Srull o. Fing } & \multicolumn{6}{|c|}{ Viton } \\
\hline \multicolumn{2}{|c|}{ Inner Magnet Cledoing } & & 3iEL S.S. & \multicolumn{2}{|r|}{ Alloy 20} & Hastelloy $\mathrm{C}$ & Hestelloy $B$ \\
\hline Bearing & Housing (4) & \multicolumn{6}{|c|}{ Ductile Iron } \\
\hline Product & Lube Botarings & \multicolumn{6}{|c|}{ Silicon Qatbige } \\
\hline
\end{tabular}

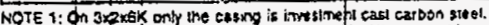

NOTE 2: Col. A Caling Covers may be provided in Aloy 20 of Hegie loy $C$ al fsclorv stion

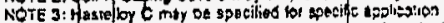

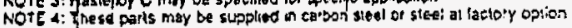

\section{MATERIAL SPECIFICATIONS}

\begin{tabular}{|c|c|c|c|}
\hline Ginerat Description & Specilfieation & Genersi Deseription & Specilficetion \\
\hline 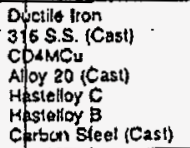 & $\begin{array}{l}\text { ASTM A395 } \\
\text { ASTM A744 CF } 8 M \\
\text { ASTM A744 CD4MCU } \\
\text { ASTM A744 CN7M } \\
\text { ASTM A494 CWVI2MW } \\
\text { ASTM A494 N12WV } \\
\text { ASTM A216 WCQ }\end{array}$ & $\begin{array}{l}3045.5 \text {. (Bolting) } \\
3165.5 \text {. (Wiought) } \\
\text { Alioy } 20 \text { (Wrought) } \\
\text { Carbon Sieal 'Eoling) } \\
\text { Carbon Sieal (Hol Roliec) } \\
\text { Carbon Steel (Key) }\end{array}$ & $\begin{array}{l}\text { ASTM A275 Type } 304 \\
\text { ASTM A276 Type } 316 \\
\text { ASTM B473 } \\
\text { ASTM A193 B7 } \\
\text { AISI } 4140 \\
\text { AISIC1019 }\end{array}$ \\
\hline
\end{tabular}




\section{"NGEFSOLLRAND.}

PUMPS.

Magnoseal"

SHOC \& SGRP PROCESS PUMPS
7116.50

Sheet 103

October, 1891

Carcels 7116.50. Sh. 103

deted Oc1 15. 1989

STANDARD MATEAIALS

PROCESS CONSTRUCTION

\begin{tabular}{|c|c|c|c|c|c|c|c|}
\hline Material Column & 01 & 5 & $\mathrm{CO} 4$ & A & $\mathrm{HC}$ & $\mathrm{HB}$ & VE (SGRP) \\
\hline Gerteral Deseription & Ductile Iron & 3165.9. & CDANCU & Alloy 20 & Mastelloy C & Hostelloy B & Glass Reiniotced Polymes \\
\hline Casing & $\begin{array}{c}\text { Duetile tron } \\
\text { (Note 1): }\end{array}$ & 316 S.S. (Cast) & CDAMCU & Alloy 20 (Cast) & Hasteiloy C & Hesla lloy B & GRP \\
\hline $\begin{array}{l}\text { Cashing tasket } \\
\text { (O-Ring on SGRP) }\end{array}$ & \multicolumn{6}{|c|}{ Non-Asbestos } & Viton \\
\hline Casing Bolting & $\begin{array}{c}\text { Carben Stent } \\
\text { (Eolting) }\end{array}$ & \multicolumn{6}{|c|}{ (Bolling) } \\
\hline Impeller & $\begin{array}{c}\text { Carbon St } \\
\text { (Casi) }\end{array}$ & $\begin{array}{c}3185.5 \\
\text { (Cest) }\end{array}$ & CDAfucu & $\begin{array}{c}\text { Alloy } 20 \\
\text { (Cast) }\end{array}$ & Hastesoy $C$ & Hestelloy & GRP \\
\hline Casng Corer & & $\begin{array}{l}316 \text { S.S. } \\
\text { (Cast) }\end{array}$ & & $\begin{array}{c}\text { Ailoy 20) } \\
\text { (Cast) (Note 2) }\end{array}$ & Hastelioy C & Hastelley B & GRP \\
\hline Snapt-pump (interna) & & 3165.5. & & Alloy 20 & Hastelloy C & Haslelioy B & Hasielloy C (3) \\
\hline Shaft-Bng Hsg (external) & \multicolumn{7}{|c|}{ Carbon Steel (Hot Rolled) } \\
\hline Inngl kingnet Carries & & $316 \mathrm{~L} \mathrm{S.S.}$ & & Aitoy 20 & Hasteliay C & Hestlelioy $\theta$ & Haslelloy C (3) \\
\hline Outhr Magnes Carrier (4) & \multicolumn{7}{|c|}{ Duthle iron } \\
\hline Cortiaintmen Shen & \multicolumn{7}{|c|}{ Reiniorced Crystalline Folymer } \\
\hline Sholi o.Ring & \multicolumn{7}{|c|}{ Vilon } \\
\hline Innd Magne: Cladsing & & 31EL S.S. & & Alioy 20 & Hastelioy C & Hastelloy 5 & Hastciloy C (3) \\
\hline Bearing Housting $\{4\}$ & \multicolumn{7}{|c|}{ Dusilie lian } \\
\hline Product Lube Bearings & \multicolumn{7}{|c|}{ Silicon Carbice } \\
\hline
\end{tabular}

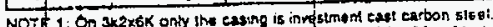

Note

NOTE 3 . Frociss thid compatibe in ateriald will be provided.

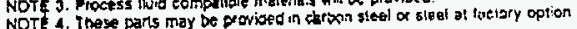

\section{MATERIAL SPECIFICATIONS}

\begin{tabular}{|c|c|c|c|}
\hline General Description & Specitication & Genetal Description & Epecifleation \\
\hline $\begin{array}{l}\text { Ductlie Iron } \\
316 \text { \$.\$. (Cast) } \\
\text { CDdlMC } \\
\text { Alloy } 20 \text { (Cast) } \\
\text { Hastelloy C } \\
\text { Hastelloy B } \\
\text { Carbon Steel (Cast) }\end{array}$ & $\begin{array}{l}\text { ASTM A395 } \\
\text { ASTM A744 CFBM } \\
\text { ASTM A744 CD4MCU } \\
\text { ASTM A744 CN7H } \\
\text { ASTM A494 CW12MW } \\
\text { ASTM A494 N12MV } \\
\text { ASTM A216 WCB }\end{array}$ & $\begin{array}{l}304 \text { S.S. (Bsting) } \\
316 \text { S S. (Wroughi) } \\
\text { Alloy } 20 \text { (Whoughl) } \\
\text { Carbon Sleel (Eclling) } \\
\text { Carbon Sleel (Hol Rolled) } \\
\text { Carbon Sloel (Key) } \\
\text { GRP }\end{array}$ & $\begin{array}{l}\text { ASTM A276 Type } 304 \\
\text { ASTM A276 Type } 316 \\
\text { ASTM B } 73 \\
\text { ASTM A193 B7 } \\
\text { AISI } 4140 \\
\text { A1SI CiO18 } \\
\text { Glass Reinforced Vinyl Ester }\end{array}$ \\
\hline
\end{tabular}

HNF-2483, Rev. 0

Page F-34 


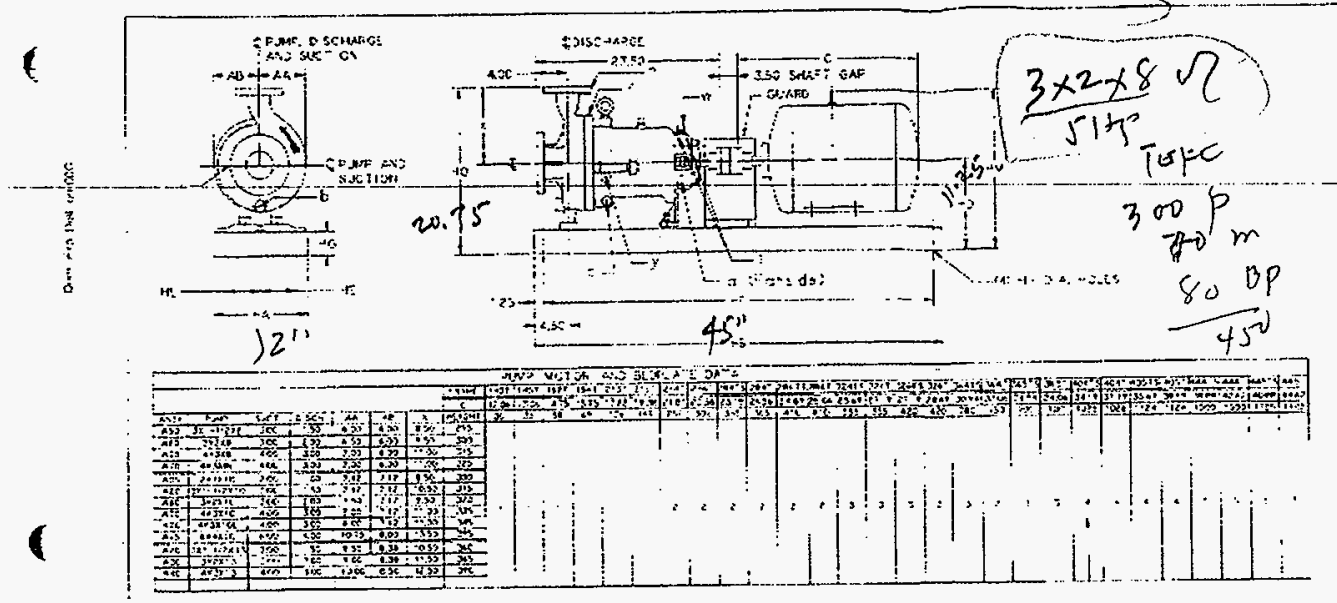

\section{NGEASOLLAAND. PURPS}

3axis vels

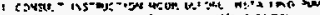
At menter

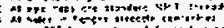

6.

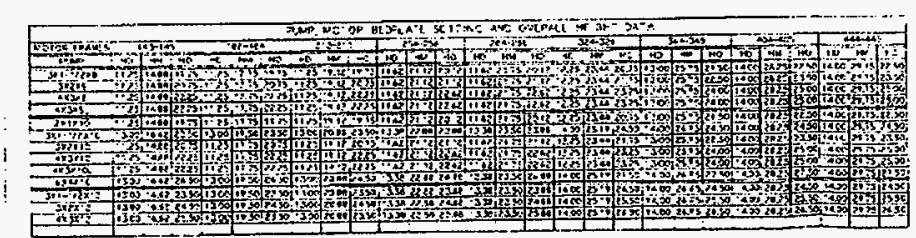

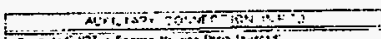

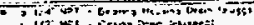

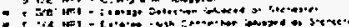

1 ye

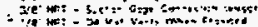

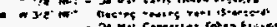

- , , ,

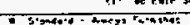
-
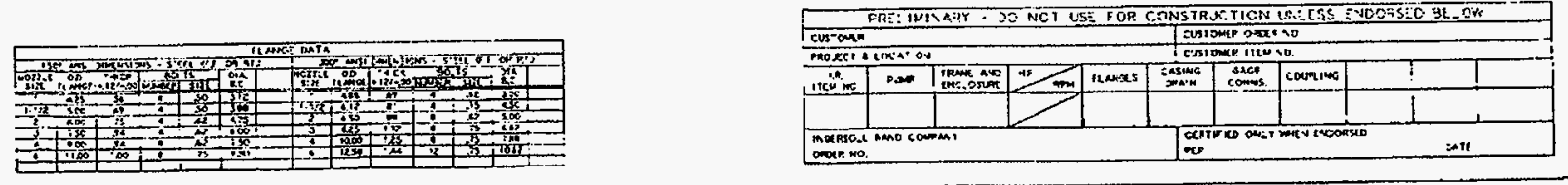

HNF-2483, Rev. 0

Page F-35 


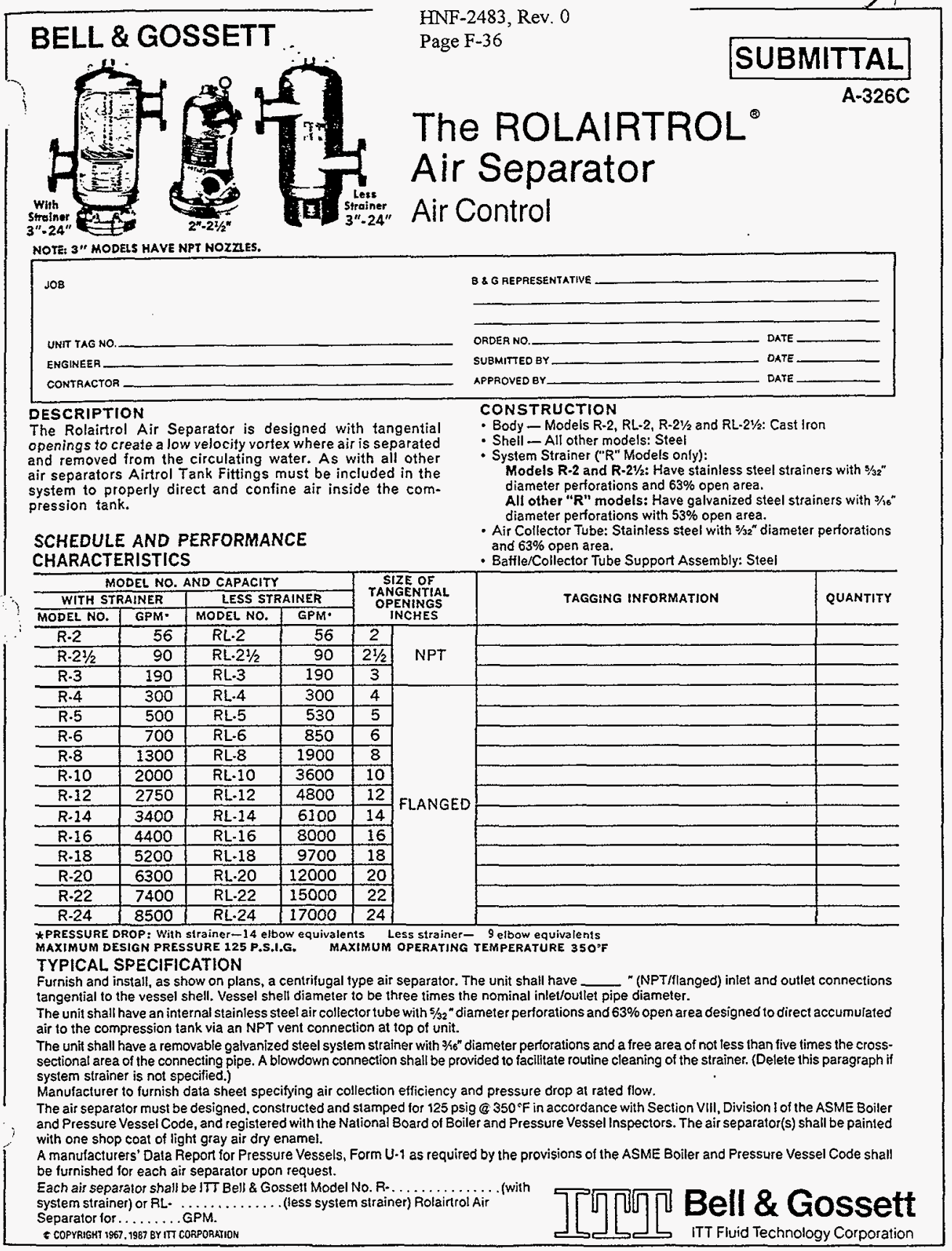




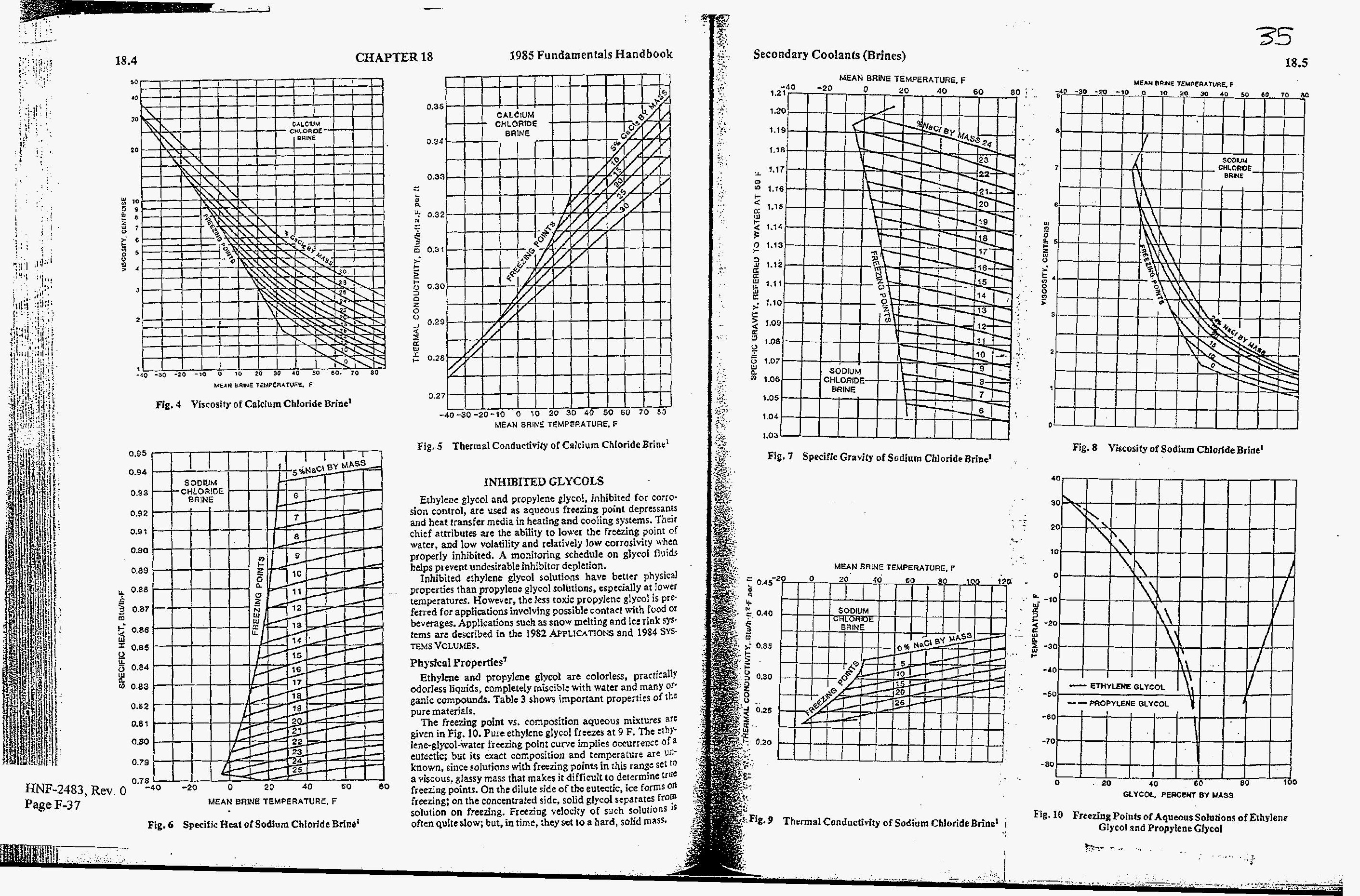




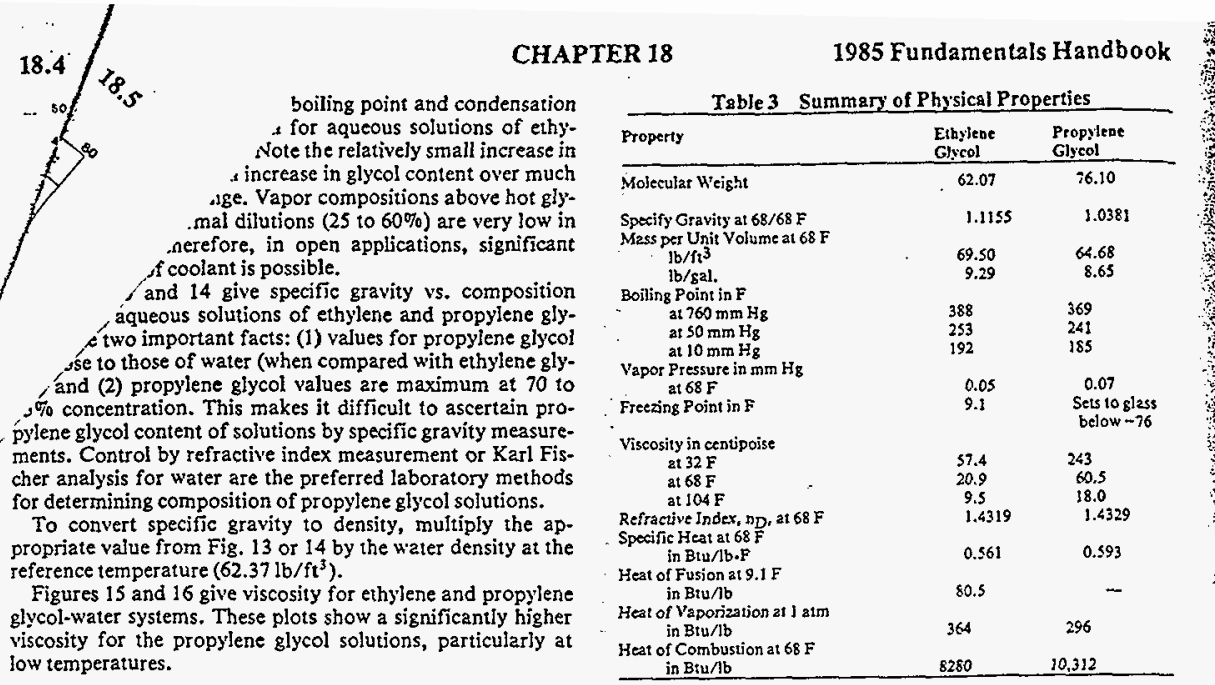

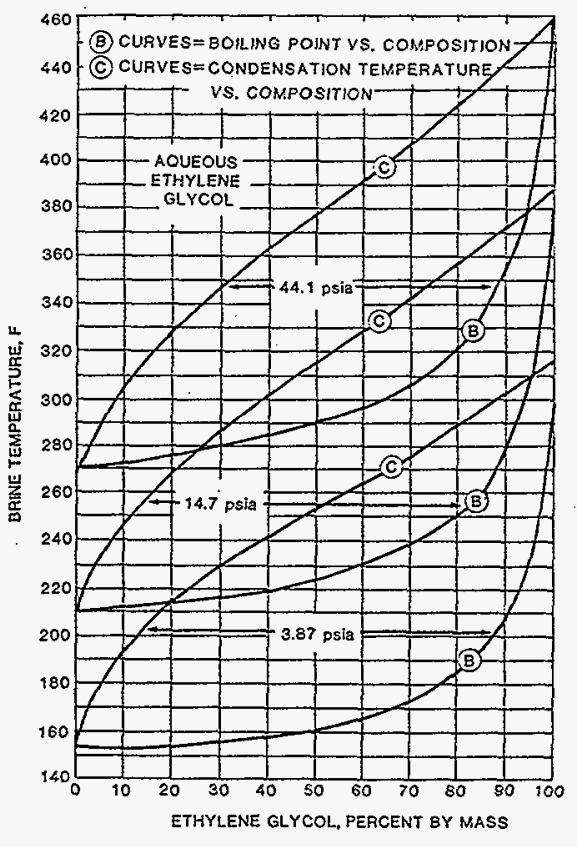

Fig. 11 Boiling Point and Condensstion of Aqueous
Solutions of Ethylene Glycol

HNF-2483, Rev. 0

Page F-38

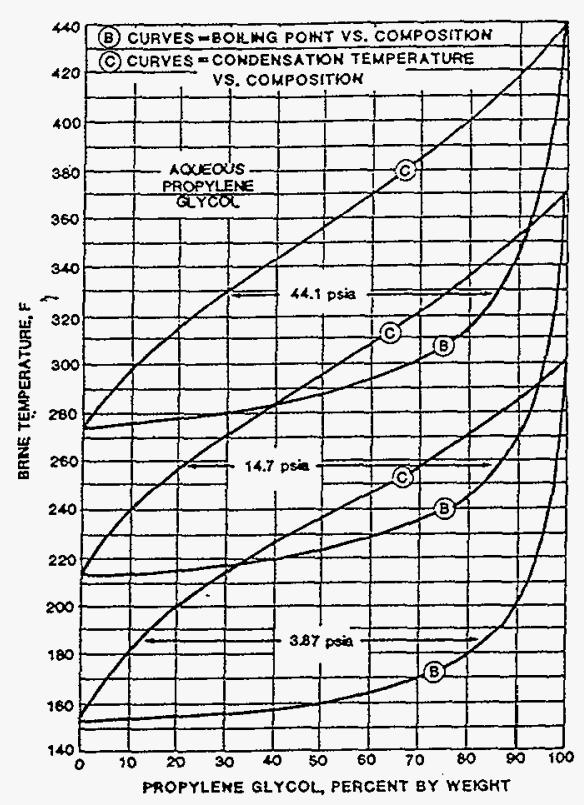

Fig. 12 Boiling Point and Condensation of Aqueous
Solutions of Propslene Glycol $\rightarrow$

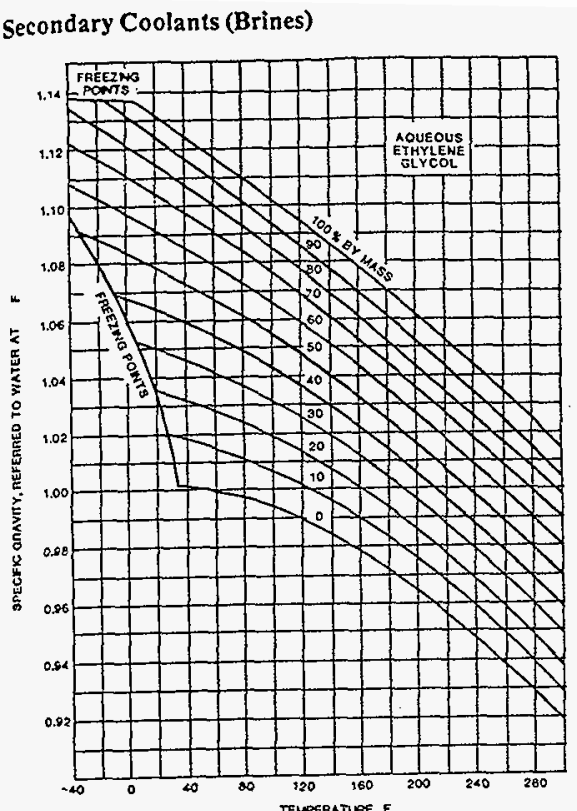

Fig. 13 Specific Gravity of Aqueous Solutions of

Figures 17 and 18 give specific heats for aqueous solutions of ethylene and propylene glycol. On an equivalent percentby-mass basis, propylene gilycol sthel sthylene glycol solutions, though neither is as efficient as water alone for heat transfer applications. Figures 19 and 20 give the thermal conductivity for aqueous ethylene glycol and propycher mal conce but water dilution of fsets this to some degree.
Additional physical property data is available from suppliers of echylene and propyjene glycol.

Corrosion Inhibition

Commercial ethylene or propylene glycol, when pure, is conservuction. Aqueous solutions of these glycols, however, assume the corrosivity of the water from which they are prepared and can become increasingly corrosive will properly inhibited. Tiss sxilied by air into acidic end products. The amount of oxjation is influenced by such factors as temperature, degree of aeration and, to some extent, the particular combination of metal components to which the glyco solution is exposed.

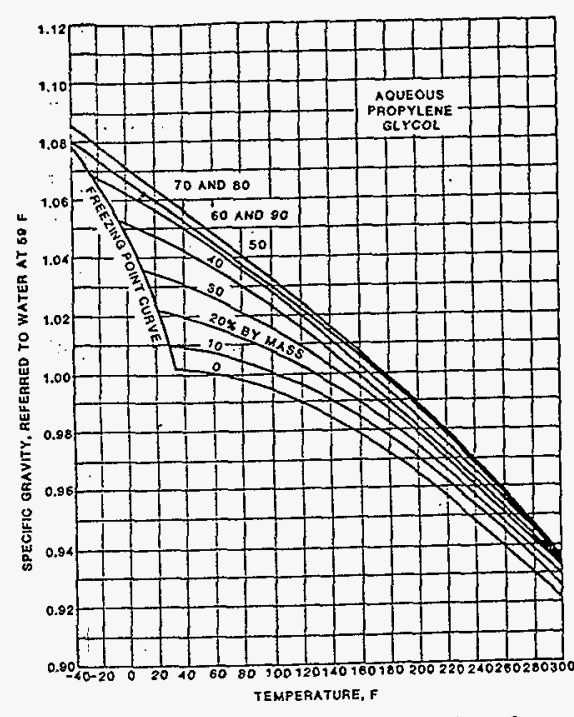

Fig. 14 Specific Gravity of Aqueous Solutions of Propylene Glycol

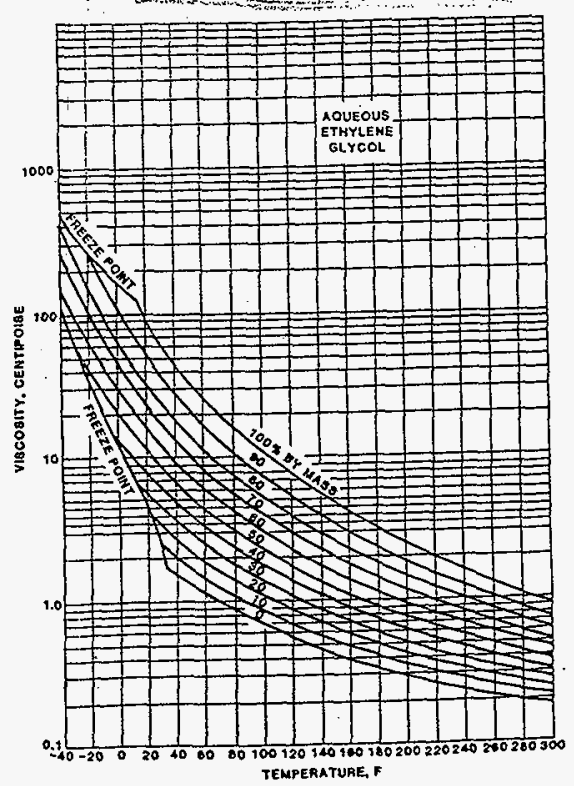

Fig. 15 Viscosity of Aqueous Solutions of Ethylene Glycol

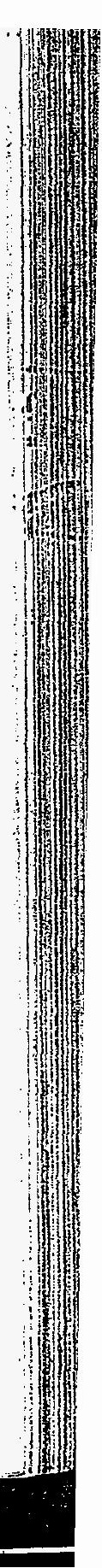




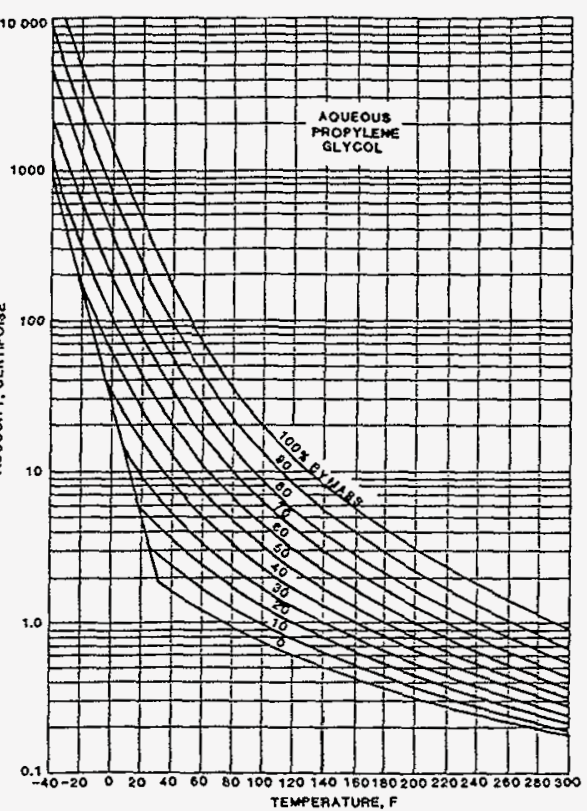

Fig. 16 Absolute Viscosity of Aqueous Solutions of From

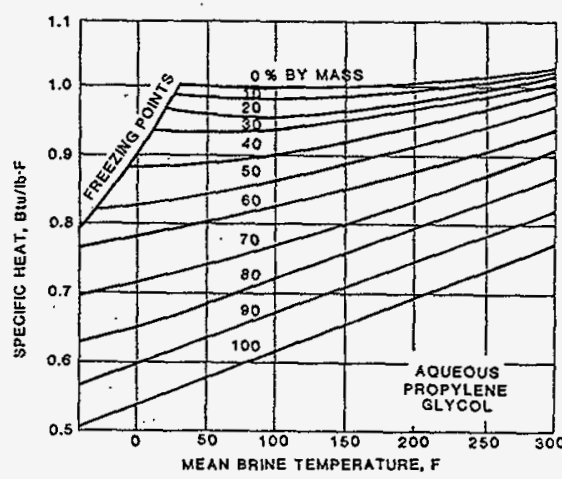

Fig. 18 Specific Heat of Aqueous Solutions of
Propylene Glycol

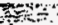

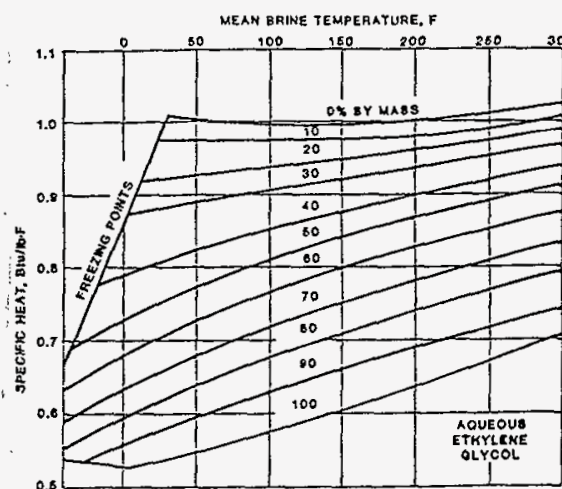

Fig. 17 Specfic Heat of Aqueous Solutions of Ethylene Glycol

Corrosion inhibition ${ }^{8}$ is perhaps most easily understood by classifying additives either as: (1) corrosion inhibitors or (2) corm a surface barrier that protects the metal from attack These barriers are usually formed by mechanisms such as adsorption of the inhibitor by the metal, or by reaction of the in hibitor with the metal or perhaps the incipient reaction prod-
uct. In most cases, metal surfaces are covered by films of their oxides that inhibitors reinforce. Environmental stabilizers or adjusters, while not corrosion inhibitors in the strict sense, decrease corrosion by stabilizing or favorably altering the overall environment. An alkaling buffer such as borax is an exampic, since its prime purpose chelating agents function as stabilizers by removing from the solution certain deleterious ions that accelerate the corrosion process or mechanism; however, exercise caution in their use. uned in conjuction with slycol solurions, because the slycol can oxidize prematurely. Generally, combinations of the two types of additives, inhibitors and stabilizers, offer the bes corrosion resistance in a given system. Can

Service Considerations

Storage and Handling. Inhibited glycol concentrates are Stable, relatively noncorsosive materials with high flash poel or aluminum vessels or even containers lined with a baks ed phenolic or vinyl resin coating, may be required. Since chemical properties of an inhibited glycol concentrate differ from those of its dilution, the effect of the concentrate on difChoose transfer pumps only after considering temperature viscosity data. Centrifugal pumps with electric motor drives are often recommended. Rubber-jmpregnated asbestos or its equivatent is a suitable pump packing materjal; a mechanical seal may also be satisfactory. Mild steel transfer piping with a mally used in conjunction with the piping, although flanged and gasketed joints are also satisfactory.

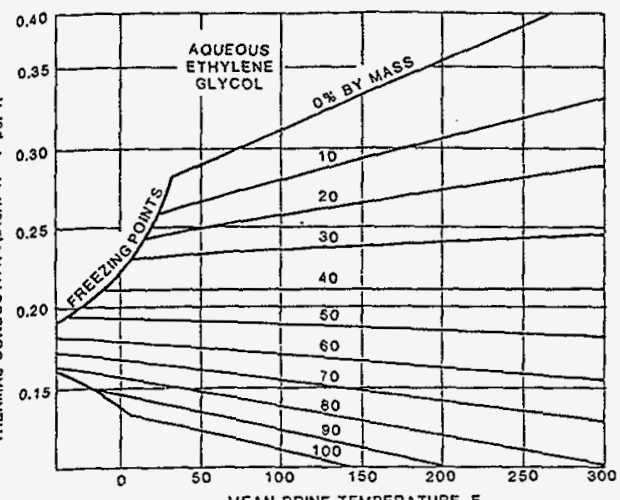

Fig. 19 Thermal Conductivity of Aqueous Solutions of

Preparation Before Application. Before an inhibited glycol is charged into a system, remove residual contaminants such hibitor functions properly. Avoid strong acid cleaners; if they are required, consider inhibited acids. Completely remove the deaning agent before charging with infited glycol.

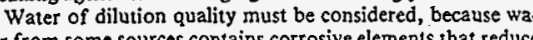
effectiveness of the inhibited formulation. Surface waters classified as soft that are low in chloride and sulfate ion conlent (less than $100 \mathrm{ppm}$ each) are preferred. Use distilled, depoor quality water. tent with potential temperature factors. In systems with a high
degree of acration, a maximum bulk fluid temperature of 180 degree of acration, a maximum bulk fluid emperature of 180 $F$ is proposed, but up to $250 \mathrm{~F}$ is permissible in a pressurized peratures should not exceed 300 to $325 \mathrm{~F}$, and should be even lower if the hot wall surface area is large in proportion to the quantity of fluid circulated. Nitrogen blanketing often helps minimize oxidation whed thiods. Peratures for extended
Operation below $-60 \mathrm{~F}$ is not recommended, although slightly lower temperatures are tolerable if the solution temperature is cycied periodically to a higher level.

Install suitabic niters because the removal of active slud and ineffective for corrosion inhibition. Consider such adsorption in filter selections.

Inhibitor Maintenance. An important factor in maintaining a glycol solution in relatively noncorrosive condition for ang period is the inhibitor monitoring and maintenance
schedule. This cannot be overemphasized. However, a specific schedule is not always easy to establish, since inhibitor depletion rate depends on the particular conditions of use. Analyses of samples immediacely after installation, after two pattern for the schedule. Visual inspection of the solution and filter residue can indicate active corrosion.
In corrosion protection, properly inhibited and maintained most systems. An indefinite service life, however, should not be expected. Avoid indiscriminate mixing of inhibited formulations. Exercise caution in replacing brine systems with inble with glycol formulations

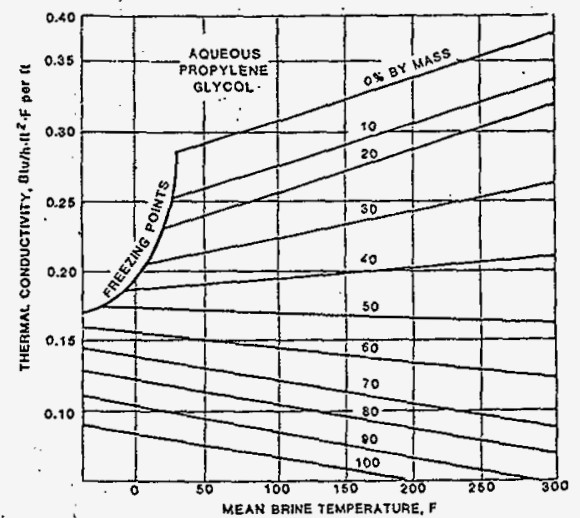

Fig. 20. Thermal Conductivity of Aqueous Solutions of Propylene Glscol

Table 4 Freezing and Boiling Points

\begin{tabular}{|c|c|c|c|}
\hline Retriperant & Name & $\begin{array}{l}\text { Freeting } \\
\text { point, }\end{array}$ & $\begin{array}{l}\text { Boflling } \\
\text { Pooint, }\end{array}$ \\
\hline $\begin{array}{r}12 \\
12 \\
32 \\
1120\end{array}$ & 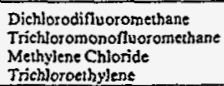 & $\begin{array}{l}-252 \\
-368 \\
-162 \\
-142 \\
-123\end{array}$ & $\begin{array}{l}-21.6 \\
74.8 \\
130.6 \\
188.4\end{array}$ \\
\hline
\end{tabular}

Trble 5 Properties of Liquid Methylese Chioride

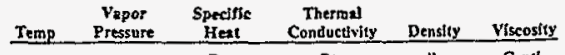

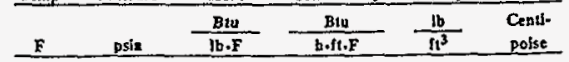

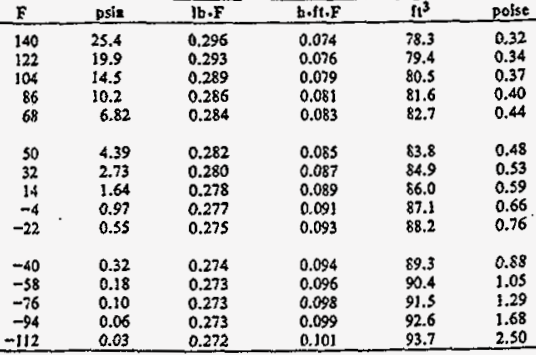

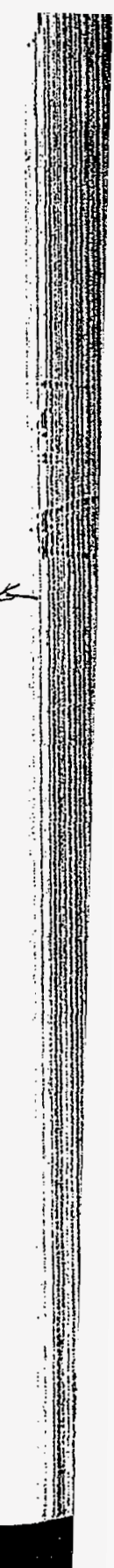


HNF-2483, Rev. 0

W320-28-008

High Efficiency Metal Filter

Shielding Input and Flushing Frequency

G- $\mathbf{i}$ 


\begin{tabular}{|l|r|l|}
\hline & CALCUIATION & Page $i$ of $i$ \\
\cline { 3 - 4 } & IDENTIFICATION AND INDEX & $6-8-94$ \\
\hline
\end{tabular}

This sheet shows the status and description of the attached Design Analysis sheets.

Discipline 28/HVAC wo/Job no. ER4319

Project No. \& Name W-320 Tank 241-C-106 Waste Retrieval

Calculation No. $1320-\frac{28}{1-008}$

w320-28-008

calculation 1tem High Efficiency Metal Filter shielding input and flushing frequency

These calculations apply to:

Dwg. No. H-2-818561

Dwg. No. $N / A$

other (Study, cDR) W-320-P3

Rev. Ho. 0

Rev. No. N/A

Rev. No. 0

The status of these calculations is:

[x] Preliminary calculations

[X] Final Calculations

[] Check calculations (on Calculation Dated)

[] Void Calculation (Reason Voided)

$\begin{array}{llll}\text { Incorporated in final orawings? } & {[]} & \text { Yes } & {[X] \text { No }} \\ \text { This calculation verified by independent "check" calculations? } & {[]} & \text { Yes } & {[X] \text { No }}\end{array}$

Original and Revised calculation Approvals:

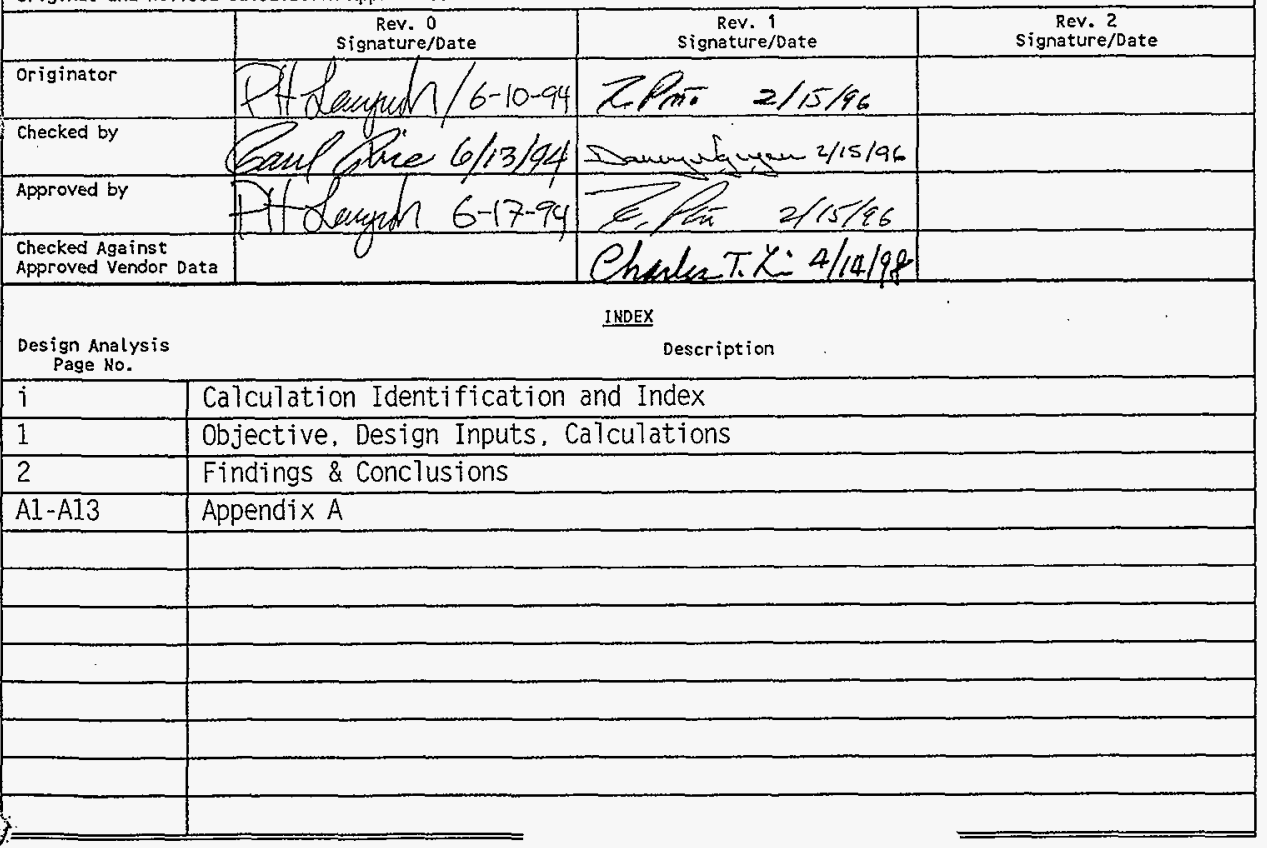

HNF-2483, Rev. 0

KEH 0378.00 (06/92) KEF072

Page G-1 


\section{DESIGN ANALYSIS}

Page No. 1 of 2

ctient WHC

subject High Efficiency Metal Filter

shielding input and flushing frequency

Location 241-C/200 East
HO/Job No. ER4319

Date $6-8-94$

checked $6 / 13 / 94$

Revised $2 / 15 / 46$
By PH Langowski

в 8. Bace

ву

1.0 OBJECTIVE

The objective of this calculation is to determine the shielding and flushing requirements for the High Efficiency Metal Filter (HEMF).

\subsection{DESIGN INPUTS}

\subsection{CRITERIA AND SOURCE}

DOE General Order 6430.1A

Functiona? Design Criteria WhC-SD-W320-FDC-001, rev. 2, 1/18/94

2.2 GIVEN DATA

The PSE values are "based on unit liter release source term values for laboratory data (conservative values) of $\mathrm{C}-106$ solids" (ref. 1. p. B-3).

\subsection{ASSUMPTIONS}

none

2.4 METHODS

Hand calculations and Excel spreadsheet.

\subsection{REFERENCES}

1. Preliminary Safety Evaluation WHC-SD-WM-PSE-010, rev. 0

2. $\mathrm{H}-2-818478$, rev. 0-33-006

3. calculation W320-E eq1, rev. 0

4. Functional Design Criteria, WHC-SD-W320-FDC-001, rev. 2

\subsection{CALCULATIONS}

3.1 Initial Shielding Design Inputs

Based on data gathered from reference 1 , a source term was determined for an initial shielding calculation. Table A-3 from ref. 1 (see App A. p. A2). Tists a value of 14.0 Rem/Liter equivalent dose to the onsite worker with plume meander. The onsite worker safety class 2 "trigger level" is 5 Rem. Therefore. 5 Rem/14 Rem/Liter $=0.357$ Liter is the safety class 2 "trigger level" source term.

Table B-1 from ref. 1 (see App A, P. A3), lists the contribution to the source term from various radionuclides on a per Liter basis. Simple addition of these constituents yields an overal1 source term of 3.32 Curie/Liter. The values in Table B-1 are assumed to be listed for pure $C-106$ solids. The FOC states that the aerosol loading consists of $10 \%$ of $C-106$ solids and $90 \%$ AY-102 liquids. Therefore, every 3.57 Liter of aerosol entering the ventilation system contains the 0.357 Liter of $C-106$ so?ids in question.

Initial source term for shielding analysis is:

(0.357 Liter) (3.32 Curie/Liter) $=1.185$ Curie

THIS CALCULATION IS SIMILAR TO REF. I EXCEPT FOR THE FOLLOWIHG: BELAUSE THE"TIME VOLUME "IN REF. I DID NOT INCLUDE THE REMOVAL EFFICIEMCIES OF THE COMPONENTS UPSTEAM OF THEHEMF, IT WAS NOT USED. THE LIQUIDS IN REF. I ARE NOT USED, SINLE WE ARE ONLY INTERESTED IN THE SOLIDS THE HEMF WILL COLLECT, 


\section{DESIGN ANALYSIS}

client WHC

subject High Efficiency Metal Filter

shielding input and fiushing frequency

Location 241-C/200 East
Calc. No. W320-H-008

Revision 0

Page No. 2 of 2

Wo/Job No. ER4319

Date 6-8-94

checked $6 / 13 / 24$

Revised
By PH Langowski

By Guce

By

\subsection{Flushing Frequency Based on Dose}

Activity levels by radionuclide as used in ref. 3 along with the mass flow accumulated on the HEMF as shown in ref. 2 are repeated on an Excel spreadsheet in App. A. This spreadsheet then calculates the accumulated dose rate on the HEMF. As modeled, the HEMF wil1 reach the 1.185 Curie level after 72 days of operation (2.4 months). The shielding is designed to mitigate the 1.185 curie field to $10 \mathrm{mR} / \mathrm{h}$ as required by the FDC (ref. 4, p. E-3). Therefore, the HEMF will require flushing every 72 days so as to not exceed the FDC imposed limits. The nonradioactive components at this 1.185 Curie level will total 180 grams.

\subsection{Flushing Frequency Based on Pressure}

3.3.1 Clean Pressure Drop. Based on information from Pa11 (see App A), using a HEMF with the following dimensions ( $A=16^{\prime \prime}, B=38^{\prime \prime}, C=68^{\prime \prime}$, vessel volume=36 gailons) yields a $6^{\prime \prime}$ w.g. pressure drop at $500 \mathrm{acfm}$ and a $3^{\prime \prime}$ W.g. pressure drop at $250 \mathrm{acfm}$. Pressure drop is known to be linear in clean filters (see Pall Brief in App A).

$250 \mathrm{acfm} / 3^{\prime \prime}$ w.g. $=83 \mathrm{acfm} / 1^{\prime \prime}$ w.g.

$180 \mathrm{acfm}=2.1 \sigma^{\prime \prime}$ w.g.

$230 \mathrm{acfm}=2.76^{\prime \prime}$ w.g.

$360 \mathrm{acfm}=4.32^{\prime \prime}$ w.g.

3.3.2 Dirty Pressure Drop. Based on information from Pall (see App A) a prototype was run at $87 \mathrm{acfm}$ and $7 "$ w.g. clean and then loaded with 19.5 grams of dust and run to a finat pressure of 10.5 " W.g. $87 \mathrm{acfm}$.

$(360 / 87)(19.5 \mathrm{~g})=80.7 \mathrm{~g}$ on a unit scaled for $360 \mathrm{acfm}$ at $10.5^{\prime \prime} \mathrm{w} . \mathrm{g}$. instead of

$(7 / 4.5)(80.7 \mathrm{~g})=125.5 \mathrm{~g}$ on a unit scaled for a $4.5^{\prime \prime}$ clean pressure drop instead of 7" w.g: clean pressure drop.

$(125.5 / 200)\left(4.5^{\prime \prime}\right.$ w.g. $)=2.82^{\prime \prime}$ w.g. clean pressure drop if sized for 200 grams loading at $10.5^{\prime \prime} \mathrm{W} . \mathrm{g}$.

Based on this information, the limiting sizing factor for a $360 \mathrm{acfm}$ unit with 4.5" W.g. maximum clean pressure drop requirement and 10.5" w.g. dirty pressure drop with 200 grams loading will be the dust loading capability. Therefore, the HEMF will be sized by the manufacturer to meet the more stringent dust loading capability requirement.

\subsection{FINDINGS \& CONCLUSIONS}

The HEMF will require flushing based on dose every 72 days. The HEMF pressure drop at

$\mathcal{L}$ this dose due to the nonradioactive components wi17 be the limiting design constraint around which the HEMF specification $(W-320-P 3)$ is written. 
APPENDIX A

HNF-2483, Rev. 0

Page G-4 
WHC-SD-WM-PSE-010, ReV. 0

P. $A_{2}$

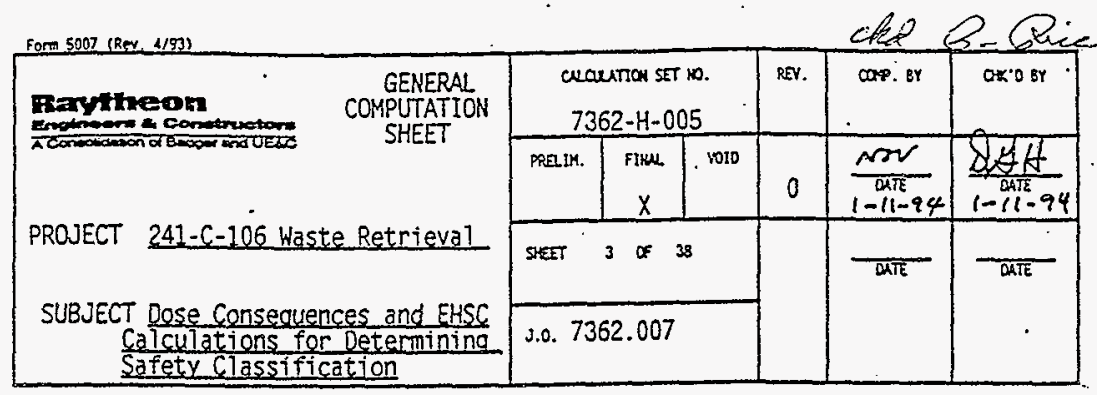

Table A-2. Unit Liter Release Dose Calculation for Onsite Individual Without Plume Meander

\begin{tabular}{|c|c|c|}
\hline Onsite & $\begin{array}{c}\text { EDE. ren/lfter } \\
\text { (solfs) }\end{array}$ & $\begin{array}{c}\text { EDE. rem/liter } \\
\text { (supernatant) }\end{array}$ \\
\hline Inhalation & $4.37 E+1$ & $3.42 E-2$ \\
\hline
\end{tabular}

Table A-3. Unit Liter Release Dose Calculation for Onsite Individual With Plume Meander

\begin{tabular}{|c|c|c|}
\hline Onsite & $\begin{array}{c}\text { EDE, rem/liter } \\
\text { (solids) }\end{array}$ & $\begin{array}{c}\text { EDE. rem/liter } \\
\text { (supernatant) }\end{array}$ \\
\hline Inhalation & $1.40 E+1$ & $1.10 E-2$ \\
\hline
\end{tabular}

2. Per Section 4:2 of Onsite/Offsite Worker Definition (issued as draft for comnent by Westinghouse Savannah River Company). a two hour evaluation period is recommended for all of fsite calculations to the general pubiic.

3. Per Items 9 and 10 of Section 4.2.1. Chapter 4.0 of Nonreactor Facility Safety Analysis Manual. WHC-CM-4-46 (Ref. 7), only inhalation and submersion pathways are considered for determining the offsite individual EDE values. as well as for onsite individual EDE values. Per Safety Classification of Systems. Components, and Structures. WHC-CM-5.46 (Ref. 8). only EDE values are needed to determine the safety classification of systems, equipment and components.

4. Design data for process systems that are considered for the accident analyses are taken from WHC-SD-W320-FDC-001. Rev. 2. Ref. 12.

5. It is assumed that the solids/sludge within the Tank AY-102 are not disturbed during sluicing from C-106 to AY-102.

6. A ground level point source release is assumed for all the accident scenarios.

7. The radioactive inventories included in Appendix B of Ref. 13 for C-106 and AY-102 (with AY-101 supernatant. see Criteria 1 and 14) are best available representative laboratory samples as stated in Appendix $C$ of Ref. 13.

HNF-2483, Rev. 0

Page G-5 


\begin{tabular}{|c|c|c|c|c|c|c|}
\hline \multirow{3}{*}{$\begin{array}{l}\text { GENERAL } \\
\text { COMPUTATION } \\
\text { SHEET }\end{array}$} & \multicolumn{3}{|c|}{ CNanttox set 10.} & \multicolumn{2}{|r|}{ cor. Br } & OX'OEY \\
\hline & Pratis. & Fine & YOID & 0 & $\frac{\text { Nor }}{1-11-94}$ & $\frac{14 k}{1-11-94}$ \\
\hline & SHET & 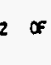 & & & DATE & क्याE \\
\hline $\begin{array}{l}\text { SUBJECT Dose Consequences and EHSC } \\
\text { Calculations for Detemining } \\
\text { Safety Classification }\end{array}$ & \multicolumn{3}{|c|}{ ง.0. 7362.007} & & & \\
\hline
\end{tabular}

Table B-1 Radlonuende Souree Tom (Rof. 13)

\begin{tabular}{|c|c|c|c|c|}
\hline \multirow[t]{2}{*}{ ISOTOPE } & \multicolumn{2}{|c|}{$\begin{array}{l}\text { C-108, SLUDGE (SNA } \\
\text { Notes below) }\end{array}$} & \multicolumn{2}{|c|}{$\begin{array}{l}\text { AY-102, SUPERNATANT(SeO } \\
\text { Not: Below) }\end{array}$} \\
\hline & 보애 & CURIESIL & $B q / L$ & CURIES/L. \\
\hline$A m-241$ & $5.56 E+7$ & 1.5OE-3 & & \\
\hline C-14 & $1.23 E+4$ & $3.32 \mathrm{E}-7$ & & \\
\hline$C 0-50$ & $4.50 \mathrm{E}+7$ & $1.22 \mathrm{E}-3$ & & \\
\hline$C=-137$ & $1.75 E+10$ & 4.73E-1 & $4.03 E+9$ & $1.09 \mathrm{E}-1$ \\
\hline $1-129$ & $4.29 E+3$ & $1.16 \mathrm{E}-7$ & & \\
\hline$P u-239 / 240$ & $1.425+8$ & $3.84 E-3$ & & \\
\hline Sr-90 & $1.08 E+11$ & $2.84 E+0$ & & \\
\hline To-99 & $1.16 E+7$ & $3.14 E-4$ & & \\
\hline U.238 & $1.53 E+4$ & 4.14E-7 & . & \\
\hline
\end{tabular}

Notes

1.

Vilued are takm from Ref. 13, See Table C.7 for AY-102 (with AY101 eupemant ind Table C-9 for C-108 sollds

2.

Per Crtterion 14 on Sh. 5, C-106 will have aupecnatemt from AY-101 via AY-102.

3.

Curies/L $=(B q / L) /(3.7 E+.10)$.

HNF-2483, Rev. 0

Page G-6 


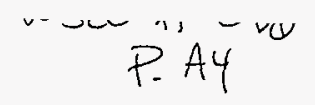

HEMF Sizing Matrix

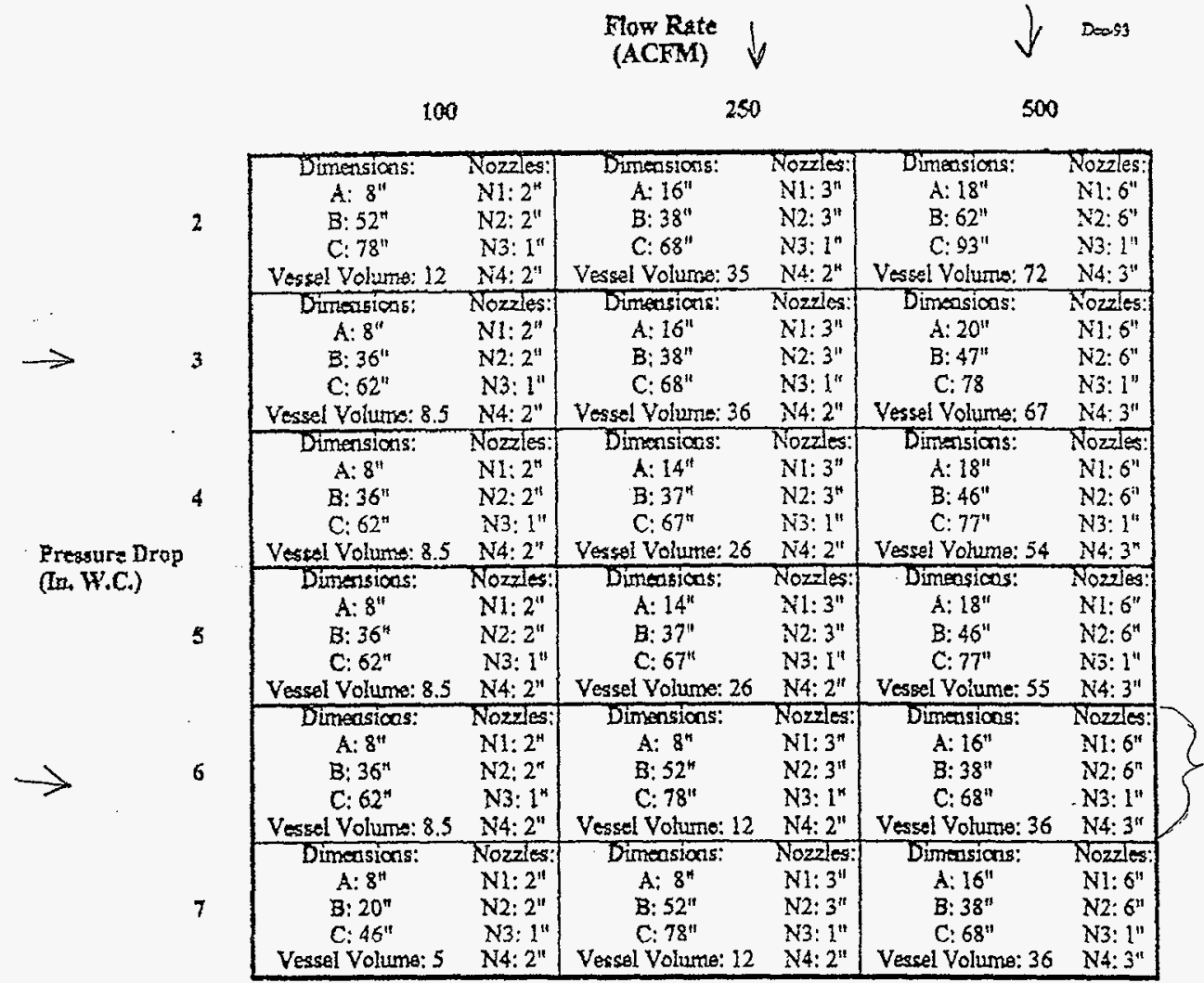

Vessel Volumes in Geallons

Note: Dimensions Refer To Drawiag No. SKA-PASS-HEMF-012

Fall Corp. Confindeatial

This Iaformetion is The Property Of Pall Corporation. And Is Furnished For Use Of The Atsigned Recipient Onty. No Cogies Are To Be Made Of The Material Containod Herein Aax it is Not To Be Divulged To Others. Elther Within Of Outside Pall Corporation Withert Spectic Aproval of An Officer Of Pall Corporation.

HNF-2483, Rev. 0

Page G-7 
145 ckd Pane 6/i3is

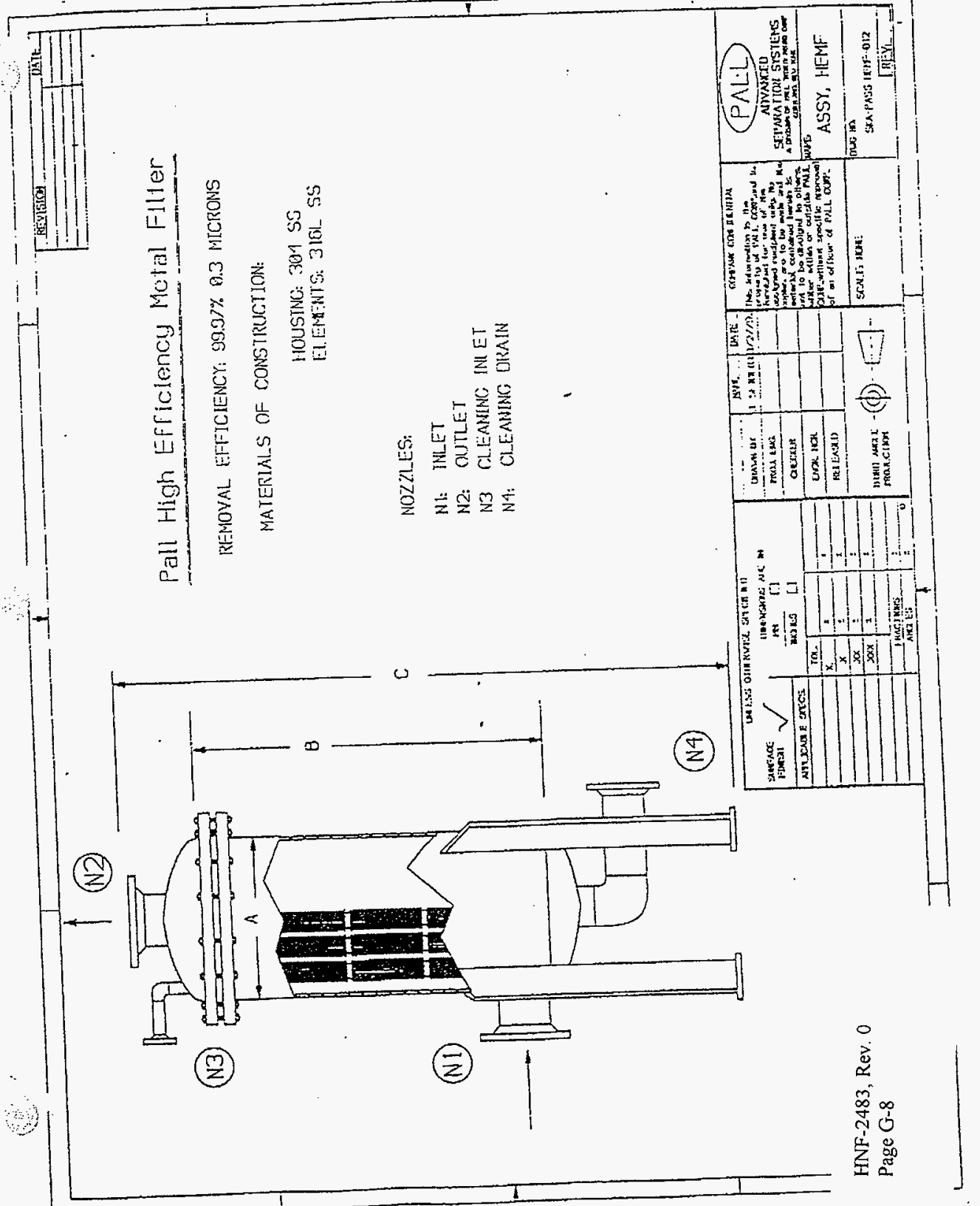


Pall Technical Brief HEMF VI

\section{BACKGROUND}

Test of dust holding capacity and efficiency of a Pall metal HEPA grade filter per ASHRAE Standard 52-76 is summarized in a recent report, (see Technical Brief HEMF-IV which follows). Testing was carried out by Air Filter Testing Laboratories, Inc. (AFIL).

The tested filter was subsequently cleaned by backwash with water. It has been retested per ASHRAE Standard 52-76, and the results are reported herein.

\section{FILTER REGENERATION}

The contaminant laden filter was shipped from AFTL to Pall's facilities in Cortland, New York, for backwash cleaning. The outlet end of the filter was mounted to a tube sheet connected via $2^{\prime \prime}$ pipe to a pressure vessel. An in-line ball valve at the filter outlet was used to control (reverse) flow of water. The tube sheet was so positioned to suspend the filter into an open 55 gallon drum to facilitate visual inspection of the filter during cleaning procedures. Differential pressure across the filter in reverse flow was thus against atmosphere, and it was measured using a pressure gauge installed close to the tube sheet.

Backwash cleaning consisted of the following sequence.

1. Static soak 15 minutes in water.

2. Reverse flush with water at 2 psid for 50 seconds. Some loosening of contaminant was noted visually. An estimated $10 \%$ of the contaminant was dislodged.

3. Reverse flush with water at 8 psid for 10 seconds. Substantial majority of the contaminant remaining evident to visual inspection was dislodged.

4. Reverse flush with water at 7 psid for 15 seconds. Little further cleaning apparent to visual irspection.

\section{RESULTS}

After cleaning the filter as indicated above, Pall shipped it back to AFIL, where pressure drop vs. flow rate was measured prior to re-challenge in accordance with ASHRAE 52-76. Pressure drop as function of flow rate is given in Figure 1. At rated flow, pressure drop was $1.38^{\prime \prime} \mathrm{H}_{2} \mathrm{O}$. This compares with 1.3 " $\mathrm{H}_{2} \mathrm{O}$ prior to initial challenge.
Re-challenge under conditions identical with those of cycle 1 showed an ingression of $371 \mathrm{gm}$ of ASHRAE test dust required post-backwash to produce terminal pressure differential of $10^{\prime \prime} \mathrm{H}_{2} \mathrm{O}$, as shown in Figure 2 .

This compares with $374 \mathrm{gm}$ in cycle 1 . As in cycle 1, effluent quality was superior to the cleanest measurable per ASHRAE Standard 52-76. The shape of Figure 2 is in close analogy with the corresponding curve generated during cycle 1 , indicating comparable dynamics of contaminant accumulation.

\section{CONCLUSION}

Backflush with water provided $>99 \%$ regeneration of dust capacity, and near complete restoration of clean pressure drop. Excellent effluent quality was maintained, without measureable change resulting from backwash.

Figure 1. Clean Filter Device (After Cleaning)

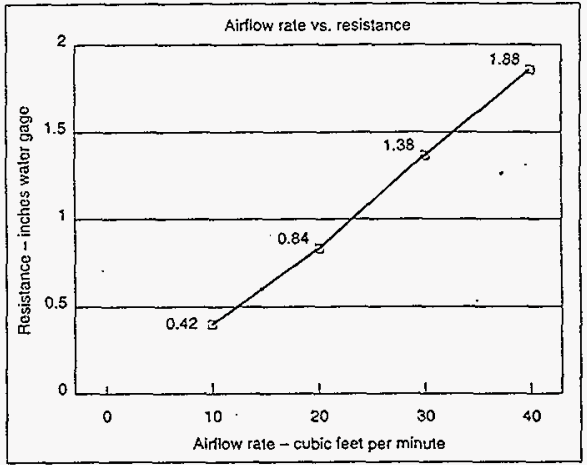

Figure 2. Dust Fed vs. Resistance

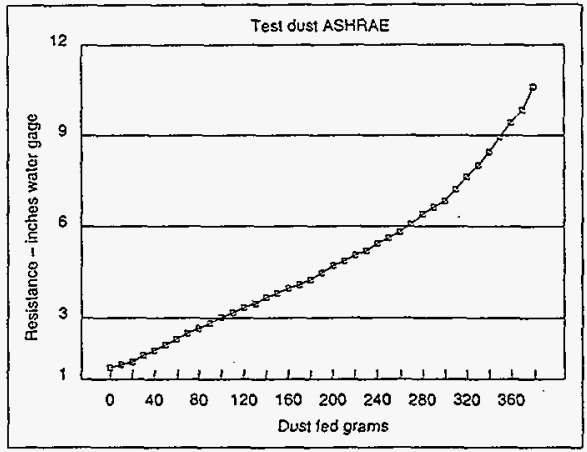


Technical Brief HEMF IV

\section{ASHRAE TEST OF PALL METAL HEPA FILTERS}

A test of dust holding capacity and filter efficiency of a Pall metal HEPA grade filter was performed per ASHRAE Standard $52-76$, by the Air Filter Testing Laboratories, Inc. (AFTL), Crestwood, KX.

The following graphical data were provided directly to Pall's Scientific and Laboratory Services Department by AFTL. Testing was performed at rated flow, producing an initial pressure differential of $1.3^{\prime \prime} \mathrm{H}_{2} \mathrm{O}$.

Pressure drop as a function of flow rate is given in Figure 3.

Figure 3. Clean Filter Device

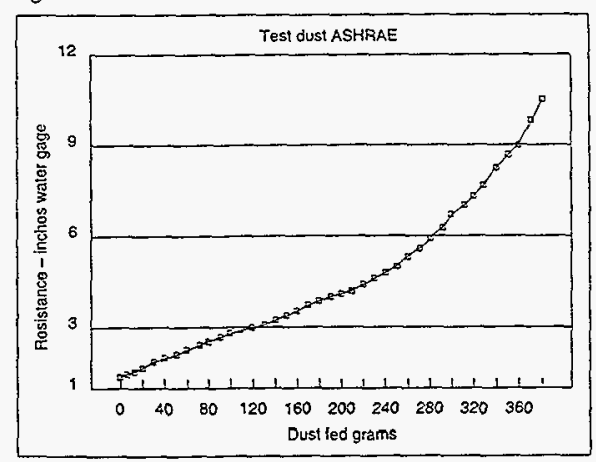

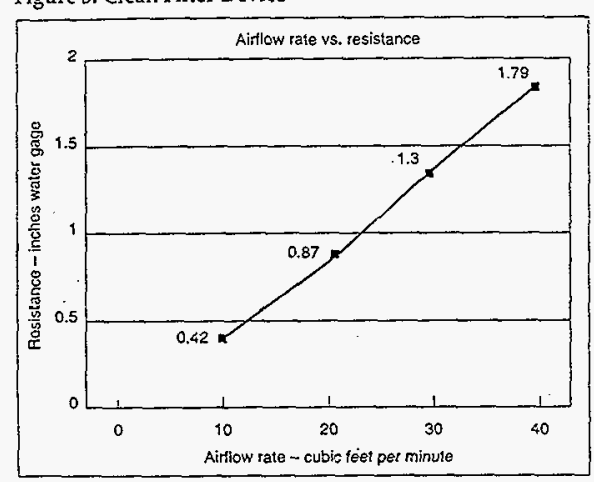

Figure 4. Dust Fed vs. Resistance

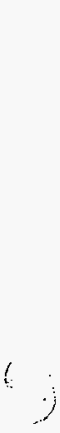

Pressure drop as a function of dust loading is ghen in Figure 4. Increase in differential is linear to approximately $4.3^{\prime \prime} \mathrm{H}_{2} \mathrm{O}$, after which an increase in rate is evident. This is consistent with cake formation, a well characterized plugging mechanism for glass fiber HEPA filters. In the present test, pressure drop increase accelerates apparently starting from the point at which cake within the pleats is deep enough to reduce effective surface area, increasing face velocity. This interpretation is also consistent with post-test visual inspection.

Per AFTL's Mr. David J. Murphy, $20 \mathrm{gm}$ of ASHRAE dust found at the housing bottom at termination of air flow may have resulted either from settling during challenge; or have fallen of the element with flow termination.

Also per Mr. Murphy, effluent quality was superior to the cleanest measurable per ASHRAE Standard 52-76. Arrestance was recorded at $100 \%$.

HNF-2483, Rev. 0

Page G-10 


\section{and 5. Guce o/13194}

$r \cdot \pi 0$

Pall Technical Brief HEMF VII

\section{BACKGROUND}

On December 2-3, 1992, a group comprised of Hanford, Kaiser Engineering, Lawrence Livermore, and Pall personnel met at facilities of Pall Land and Marine Division (PLM), New Port Richey, Florida, to witness efficiency and backwash test of Pall's stainless steel Melter Off-Gas filter assembly for Baftelle. Reported in PASS Technical Report 7, the assembly was shown before and after vigorous backwash to provide filter efficiency equivalent to two stages of HEPA filter in series(i).

Also discussed were remaining test requirements for Pall's all stainless steel Zone 1 filter, to provide single stage HEPA equivalent efficiency. Rerised test protocols for a "Fine Particle Dust Challenge," and "Moisture Challenge Test" were agreed to and circulated to all meeting participants. These are attached as Appendix 1. Pall agreed to undertake completion of these tests and to report by January 8, 1993.

Purpose of the Fine Particle test is to demonstrate dust holding capacity and filter regenerability without loss of integrity, following challenge using smaller diameter particles (more penetrating size distribution) than those found in ASHRAE Test Dust(2). It should be noted that ASHRAE Test Dust is formulated to simulate ambient air-borne dust as encountered by filters in HVAC applications.

Present Tests of Pall metal filter technology to ASHRAE Standard 52.1-1992, performed by the Air Filter Test Laboratories, Inc., have been summarized(i). The siliceous dust component of the ASHRAE contaminant is comprised of PII SAE Fine Test Dust( ${ }^{(4)}$.

Pall's Scientific and Laboratory Services Department (SLS) has carried out the Fine Particle Dust Challenge, and the results are herein reported. The Moisture Challenge Test has also been completed by SLS, and the results are reported in reference ${ }^{(i)}$.

\section{TEST METHODS}

Test protocol is given in Appendix I, Section IIA, attached. Tests employed a Pall Zone 1 filter module, $6^{\prime \prime}$ OD by $15.75^{\prime \prime}$ in length. Note: The same filter was then tested by Moisture Challenge (Appendix I, Section IIB), without further cleaning or other treatment(5).

$$
\begin{aligned}
& \text { HNF-2483, Rev. } 0 \\
& \text { Page G-11 }
\end{aligned}
$$

All DOP tests were carried out at $87 \mathrm{CFM}$, using methods previously reported(6).

\section{Fine Dust Challenge.}

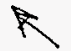

The Zone 1 module was housed downstream of a Pall Centrisep ${ }^{\circ}$ unit designed to operate at 87 CFM plus $10 \%$ scavenge flow, in accordance with Appendix 1 . The test system is shown schematically in Figure 1.

Figure 1. Test Stand Configuration for Fine Dust Loading.

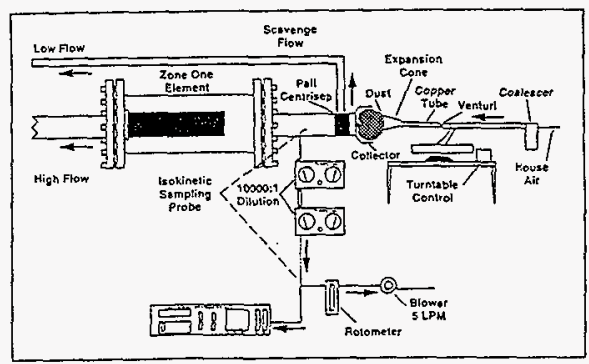

Challenge was carried out by educting PTI SAE Fine Test Dust at approximately $260 \mathrm{gm}$ per hour to the upstream Centrisep unit via a venturi at sonic throat conditions, and a difuser cone. Effluent of the Centrisep unit flowed directly to the Zone 1 filter. Pressure drop across the Zone 1 filter was monitored using a calibrated Magnehelic gauge.

Photographic views of the test stand are given as Photos A and B.

\section{Contaminant Particle Mass/Size Distribution.}

Mass distribution was monitored by isokinetic sampling in conjunction with a calibrated Particle Measuring Systems LAS- $X$ laser spectrophotometer to measure particle counts influent to the Zone 1 filter (Figure 1).

In separate tests using the Figure 1 configuration but without the Zone 1 filter, the LAS-X counter was found to demonstrate a sharp distinction between PTI SAE Fine Test Dust and Centrisep effluent of this contaminant.

The LAS-X counter resolves particle diameter into 16 channels or "bins", to as small as $0.09 \mu \mathrm{m}$; the largest bir as $>3.0 \mu \mathrm{m}$. Count in a given bin is reproducible to $\pm 10 \%(1)$. Two TSI Model 3302 diluters were used in series at a total 10,000 fold dilution, to prevent count sensor saturation. 
3. PTI SAE Fine Test Dust removal efficiency of the Centrisep unit was measured at $\$ S .1 \%$ by weight (11.9\% transmission).

4. Particle counts with and without the Centrisep unit in place at equal dust aspiration rate are given in Table 2. Background counts prior to dust ingression were of the order of $10 \%$ in channels $1-3$, and at $\leq$ $2 \%$ in higher channels.

Average counts per minute are virtually identical with and without Centrisep processing in the $.09 \mu \mathrm{m}$ $-2 \mu \mathrm{m}$ ranges (bins 1 to 13 ), demonstrating $0 \%$ particle rejection. Between 2.5 and $3.0 \mu \mathrm{m}, 35 \%$ rejection of counts is demonstrated; $>3 \mu \mathrm{m}$ the rejection rate is at $65 \%$. These data indicate measureable efficiency for the Centrisep unit down into the $2.0-2.5 \mu \mathrm{m}$ diameter range.

The count and gravimetric efficiency data are consistent. Mass distribution is a cubic function of particle radius, and larger particles strongly predominate mass even at lower count.

By Coulter counter test, PII reports the volume (i.e.

Photo $C$. Representative Zone 1 module appearance at outset of Protocol IIA, Appendix I.

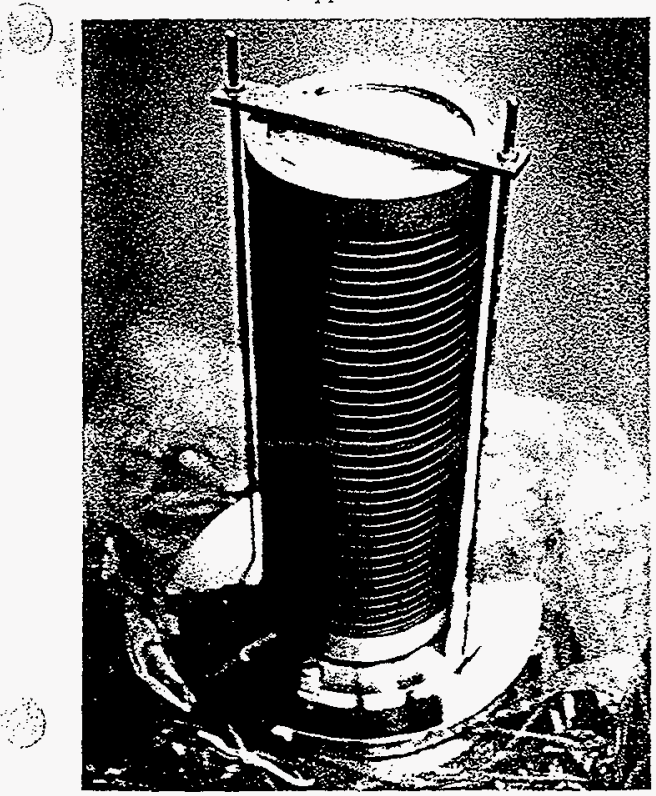

$$
\text { CEd 5 SHer b/3/94 }
$$

mass) of particles sicatur than $10 \mathrm{\mu m}$ in siameter in PTI SAE Fine Test Dust as $45^{\circ}$ " Reported fraction greater than $20 \mu \mathrm{m}$ is $2 \vec{r}^{\prime \prime}$. This determination is made in liquid, under comojtions to promote disagglomeration potentially more rigorous than the standard method in air (employed here) of transport through a converging/diverging nozzle under sonic conditions.

Thus, count data (Table 2) together with the substantial volume significance of particles $>10 \mu \mathrm{m}$ in untreated dust, confirm Centrisep effluent particle mass distribution to he highly skewed toward smaller diameters. Centrisep processed dust is expected to be substantially more penetrating than untreated PTI SAE Fine Test Dust.

5. Fine Particle Dust load on the Zone 1 filter to $10 " \mathrm{H}_{2} \mathrm{O}$ differential was $19.5 \mathrm{gm}$. This is obtained by applying the gravimetric reduction factor measured for the upstream Centrisep unit to the total weight of dust aspirated.

Pressure drop is. Fine Dust loading of the Zone 1 filter module is given as Figure 2. Linear trend of

Photo D. Photographic record of appearance of tested element at conclusion of Protocol IIA, Appendix I. .

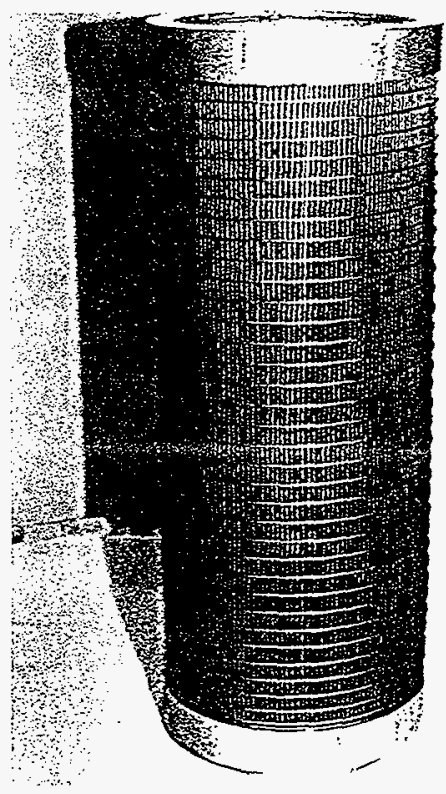

HNF-2483, Rev. 0

Page G-12 
Figure 2. $\Delta \mathrm{P}$ vs. Weight Loaded,

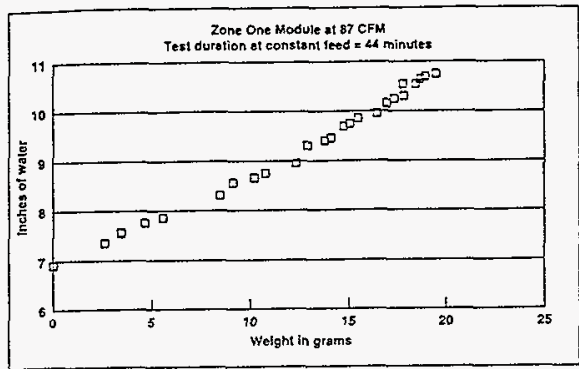

pressure drop increase at constant flow rate indicates a cake building mechanism of contaminant accumulation. Visual inspection of the element after dust loading showed a uniform color change consistent with that of the ingressed dust. However, no cake could be detected visually or at $10 \times$ magnification.

6. Particle counts taken during challenge are given in Table 3. Background counts prior to dust ingression were at a level comparable with that reported in section 4 , above.

Although total feed rate varied somewhat, \% size (and therefore \% mass) distribution (Table 3) was reproducible with that of Centrisep effluent in Table 2.

7. Maximum reverse pressure drop during backwashes is given in Table 1. cho be Gre b/13iั94

$\bar{P}, A T \bar{O}$

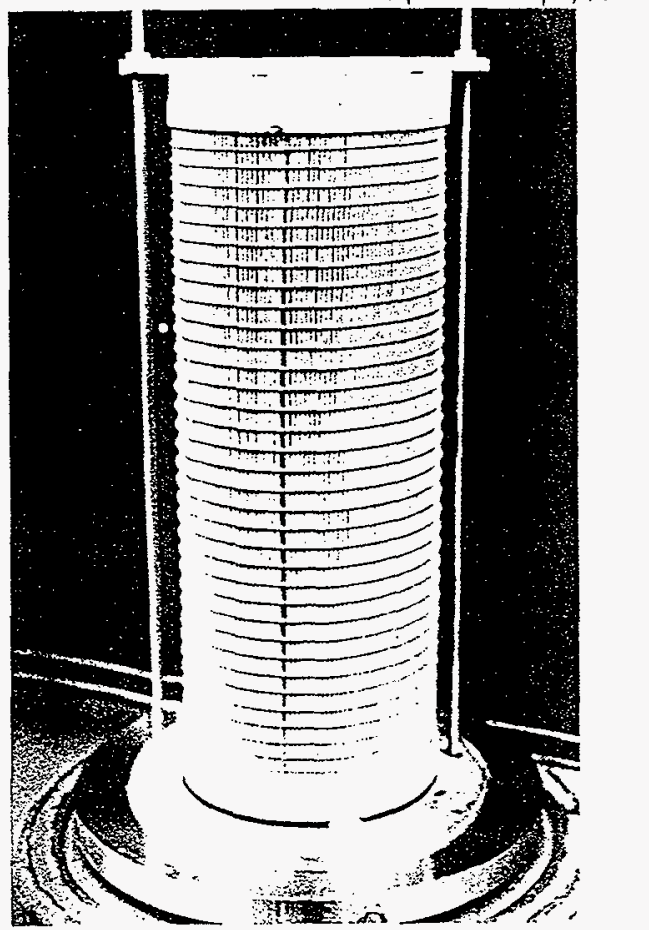

Photo E. Following dust loading to $10^{\prime \prime} \mathrm{H}_{2} \mathrm{O}$ over clean pressure drop per test Protocol il A, Appendix 1, the photographic record of appearance of tested element was prepared.

Table 2. Particle size distribution PTI SAE fine test dust with and without stripping by a Pall Centricep.

\begin{tabular}{|c|c|c|c|c|c|c|c|c|c|c|c|c|c|c|c|c|}
\hline $\begin{array}{l}\text { With Centricep } \\
\text { Channel Numbers }\end{array}$ & 1 & 2 & 3 & 4 & 5 & 6 & 7 & 8 & 9 & 10 & 11 & 12 & 13 & 14 & 15 & 16 \\
\hline \multirow[t]{2}{*}{ Channel range in $\mu \mathrm{m}$} & 0.09 & $0.11-$ & $0.15-$ & 0.20 & 0.25 & 0.30 & 0.40 & 0.50 & $0.65=$ & $0.80-$ & 1.00 & 1.25 & 1.50 & 2.00 & $2.50-$ & \multirow[t]{2}{*}{$>3.0$} \\
\hline & 0.11 & 0.15 & 0.20 & 0.25 & 0.30 & 0.40 & 0.50 & 0.65 & 0.80 & 1.00 & 1.25 & 1.50 & 2.00 & 2.50 & 3.00 & \\
\hline Average count & 73.17 & 190.3 & 372.3 & 384.7 & 323.2 & 526.1 & 390.3 & 356.8 & 209.5 & 156.8 & 112.2 & 68.83 & 74.5 & 34.58 & 20 & $34.5 \mathrm{~S}$ \\
\hline$\%$ Total count & 2.20 & 5.72 & 11.19 & 11.56 & 9.71 & 15.81 & 11.73 & 10.72 & 6.30 & 4.71 & 3.37 & 2.07 & 2.24 & 1.04 & 0.60 & $1.0 \div$ \\
\hline \multirow{2}{*}{$\begin{array}{l}\text { Without Centricep } \\
\text { Channel Numbers }\end{array}$} & & & & & & & & & & & & & & & & \multirow[b]{2}{*}{16} \\
\hline & 1 & 2 & 3 & 4 & 5 & 6 & 7 & 8 & 9 & 10 & 11 & 12 & 13 & 14 & 15 & \\
\hline \multirow[t]{2}{*}{ Channel range in $\mu \mathrm{m}$} & 0.09 & $0.11-$ & $0.15-$ & 0.20 & $0.25-$ & 0.30 & $0.40-$ & $0.50-$ & 0.65 & $0.80-$ & 1.00 & $1.25-$ & 1.50 & $2.00-$ & 2.50 & \multirow[t]{2}{*}{$>3.0$} \\
\hline & 0.11 & 0.15 & 0.20 & 0.25 & 0.30 & 0.40 & 0.50 & 0.66 & 0.80 & 3.00 & 1.25 & 1.50 & 2.00 & 2.50 & 3.00 & \\
\hline Average count & 76 & 200 & 393 & 385 & 319 & 511 & 369 & 347 & $19 \div$ & 147 & 113 & 72 & 87 & 48 & 31 & 99 \\
\hline$\%$ Total count & 2.23 & 5.89 & 11.60 & 11.37 & 9.42 & 15.07 & 10.89 & 10.24 & 5.71 & 4.33 & 3.32 & 2.12 & 2.57 & 1.41 & 0.92 & 2.91 \\
\hline
\end{tabular}

Note: With Centricep = An average of 12 one minute counts.

Without Centricep $=$ An average of 11 one minute courts. 
Stroam $15 \mathrm{HEMF} / \mathrm{s}$ sal pot

\begin{tabular}{|c|c|c|c|c|c|c|}
\hline Radionuclida & activity $(\mathrm{Cl} / \mathrm{g})$ & flow (pci/min) & flow (Ci/min) & flow (magimin) & total Curio & total flow $\{\mathrm{mgl}$ \\
\hline$c-14$ & $4.46 E+00$ & $2.00 \mathrm{E}-01$ & $2.00 \mathrm{E}-13$ & $4.48 \mathrm{E}-11$ & $2.07 E-08$ & $4.64 \mathrm{E}-06$ \\
\hline $\mathrm{Co} \cdot 60$ & $1.13 E+03$ & $2.00 E+03$ & 2.00E-09 & 1.77E-09 & 2.07E-04 & $1.83 \mathrm{E}-04$ \\
\hline $5 \mathrm{~T}-90$ & $1.37 E+02$ & $4.20 E+0 G$ & $4.20 \mathrm{E}-06$ & $3.07 \mathrm{E}-05$ & $4.35 \mathrm{E}-01$ & $3.17 E+00$ \\
\hline $\mathrm{Y}-90$ & $5.45 E+05$ & $4.20 E+06$ & $4.20 \mathrm{E}-06$ & $7.71 \mathrm{E}-09$ & $4.35 \mathrm{E}-01$ & $7.98 \mathrm{E}-04$ \\
\hline TC-99 & $1.70 \mathrm{E}-02$ & $3.40 E+02$ & $3.40 \mathrm{E}-10$ & $2.005-05$ & $3.52 E-05$ & $2.07 E+00$ \\
\hline$S b-125$ & $1.04 \mathrm{E}+03$ & $2.20 E+04$ & $2.20 \mathrm{E}-08$ & $2.12 \mathrm{E}-08$ & $2.28 E-03$ & $2.19 \mathrm{E}-03$ \\
\hline $1-129$ & $1.73 \mathrm{E}-04$ & $0.00 E+00$ & $0.00 E+00$ & $0.00 \mathrm{E}+00$ & $0.00 E+00$ & $0.00 \mathrm{E}+00$ \\
\hline Cs-137 & $8.66 \mathrm{E}+07$ & $1.30 E+06$ & $1.30 \mathrm{E}-06$ & $1.50 \mathrm{E}-05$ & $9.35 \mathrm{E}-01$ & $1.55 E+00$ \\
\hline $\mathrm{mBa} \cdot 137$ & $5.38 E+08$ & $1.60 E+06$ & $1.60 \mathrm{E}-06$ & $2.97 \mathrm{E}-12$ & $1.66 \mathrm{E}-01$ & $3.08 \mathrm{E}-07$ \\
\hline $\mathrm{Ce}_{-144}$ & $3.19 E+03$ & $9.30 E+04$ & $9.30 \mathrm{E}-08$ & $2.92 \mathrm{E}-08$ & $9.63 \mathrm{E}-03$ & $3.02 \mathrm{E}-03$ \\
\hline Eu-154 & $2.73 E+02$ & $2.30 \mathrm{E}+04$ & $2.30 \mathrm{E} \cdot 08$ & $8.42 \mathrm{E}-08$ & $2.38 \mathrm{E}-03$ & $8.72 \mathrm{E}-03$ \\
\hline Pu.239 & $6,20 E-02$ & $4.00 E+03$ & $4.00 \mathrm{E}-09$ & $6.45 \mathrm{E}-05$ & $4.14 \mathrm{E}-04$ & $6.68 \mathrm{E}+00$ \\
\hline $\mathrm{PU}-240$ & $2.28 \mathrm{E}-01$ & $6.30 E+01$ & $6.30 \mathrm{E}-11$ & $2.76 \mathrm{E}-07$ & $6.52 \mathrm{E} .06$ & $2.86 \mathrm{E}+02$ \\
\hline Am-241 & $3.43 E+00$ & $3.60 \mathrm{E}+03$ & $3.60 \mathrm{E}-09$ & $1.05 E-06$ & $3.73 E-04$ & $1.09 \mathrm{E}-01$ \\
\hline
\end{tabular}

Stream 16 HEPA1

HEMFJDF $=3000$

0.000395 Curie

Radiation Shielding Study had $50 \mathrm{mRem} / \mathrm{hr}$ contact

on housing after 0.0682 Curie collected.

HEPA 1 will be changed out after 173 flushes

of the HEMF. HEPA1 will not roquire changing out

until the end of the project.

total $=\quad 1.185$ Curie $\quad$ safoty class 2 "triggor lovel"

Assums upstream components function properly $\left(D F=1,25^{*} 3^{*} 20=75\right.$ )

time $=103,511$ minutes

1,725 hours
1,511 minutes

1,725 hours
72 days

2,4 months

Flush every 2 and one half months and on final decon before removal.

Assuming no removal upstream of the HEMF

$$
1,380 \text { minutes }
$$

23 hours

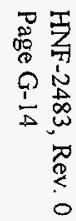

1 days

Administrative radiation measurements every day to vorify permanent rad monitor .

Administrative reading can be made on exterior of shiolding. If less than $10 \mathrm{mR} / \mathrm{h}$ then critoria is met. 


\begin{tabular}{|c|c|r|}
\hline $\mathrm{Cs}-137$ & $1.50 \mathrm{E}-05$ & $1.55 \mathrm{E}+00$ \\
\hline $\mathrm{mBa}-137$ & $2.97 \mathrm{E}-12$ & $3.08 \mathrm{E}-07$ \\
\hline $\mathrm{Ce}-144$ & $2.92 \mathrm{E}-08$ & $3.02 \mathrm{E}-03$ \\
\hline $\mathrm{Eu}+154$ & $8.42 \mathrm{E}-08$ & $8.72 \mathrm{E}-03$ \\
\hline $\mathrm{Pu}-239$ & $6.45 \mathrm{E}-05$ & $6.68 \mathrm{E}+00$ \\
\hline $\mathrm{Pu}-240$ & $2.76 \mathrm{E}-07$ & $2.86 \mathrm{E}-02$ \\
\hline $\mathrm{Am}-241$ & $1.05 \mathrm{E}-06$ & $1.09 \mathrm{E}-01$ \\
\hline
\end{tabular}

total $=$

1.743

180393

milligrams

grams

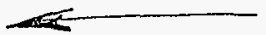

4.96

pressure drop from loading " w.g.

9.46

total pressure drop " w.g.

Assume upstream components function properiy

$\begin{array}{ccl}\text { time }= & 103,511 & \text { minutes } \\ 1,725 & \text { hours } \\ 72 & \text { days }\end{array}$

$\begin{array}{ll}72 & \text { days } \\ 2.4 & \end{array}$

Flush every 2 and one half months and on final decon before removal.

$\begin{array}{cc}0 \\ 0 \\ 0 \\ 0 \\ 0 \\ 0 \\ 1 & 1 \\ 0 & 1 \\ 0 & 1 \\ 0 & 0 \\ 0 & 0 \\ 0\end{array}$ 
HNF-2483, Rev. 0

W320-28-011

Exhaust Skid Stack Sizing and Fan Sizing

$\mathrm{H}-\mathrm{i}$ 


\section{CALCULATION IDENTIFICATION AND INDEX}

This sheet shows the status and description of the attached Design Analysis sheets.

Discipline 28/HVAC

wo/Job No. ER4319

Calculation No. 1320 H 011

Project No. \& Name W-320 Tank 241-C-106 Waste Retrieval

$\omega 320-28-011$

Calculation Item Exhaust Skid Stack Sizing and Fan Sizing

These calculations apply to:

Dwg. No. N/A

Rev. No. N/A

Dwg. No. N/A

Rev. No. N/A

Other (Study, CDR) Procurement Specifications:

W-320-PI Exhaust Skid Rev. No. preliminary

The status of these calculations is:

[] Preliminary Calculations

[x] Final Calculations

[] Check Calculations (On Calculation Dated)

[] Void Caiculation (Reason Voided)

Incorporated in Final Orawings?

[] Yes $[X]$ No

This calculation verified by independent "check" calculations? [] Yes [X]

№

Original and Revised Calculation Approvals:

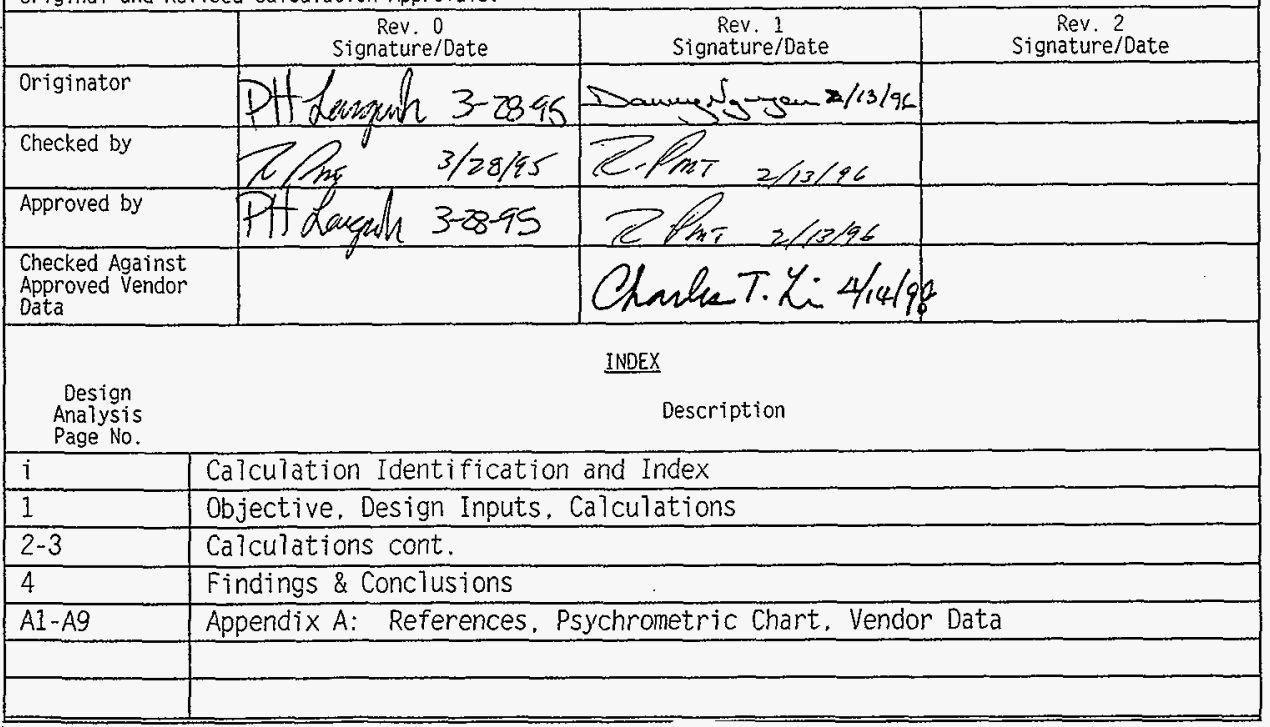

HNF-2483, Rev. 0

KEH $0378.00(06 / 92)$ KEF072

Page $\mathrm{H}-1$ 
Calc. No. W320-K-011

Revision 0

\section{DESIGN ANALYSIS}

Client WHC

Subject Exhaust Skid Stack Sizing \& Fan Sizing

Location 241-C/200 East
Wo/Job No. ER4319

Date 3-28-95

Checked $3 / 28 / 95$

Revised
Page No. 1 of 5

By PH Langowski

By P. Prí

By

\subsection{OBJECTIVE}

The objective of this calculation is to determine the stack sizing required for input to the Exhaust Skid procurement specification. The calculation shall also size the pressure drop on the Exhaust Skid for fan sizing input to the Exhaust Skid procurement specification and estimate heating coil and exhaust fan power requirements.

\subsection{DESIGN INPUTS}

\subsection{CRITERIA AND SOURCE}

DOE General Order $6430.1 \mathrm{~A}$

Functional Design Criteria WHC-SD-W320-FDC-001, rev. 2, 1/18/94

\subsection{GIVEN DATA}

1. Upstream pressure drop information from $\mathrm{W} 320-\mathrm{H}-018$, rev. 1

\subsection{ASSUMPTIONS}

no major assumptions, see text for minor assumptions.

\subsection{METHODS}

Hand calculations.

\subsection{REFERENCES}

1. W320-P1 rev. 0 (IFA draft date 3-29-95) Procurement Specification. Exhaust Skid Ventilation Air Cleanup Trains

2. W320-H-018 rev. 1 Calculation. Pressure Loss Upstream of the Exhaust Skid

3. 1993 ASHRAE Fundamentals

4. SDC 5.1 rev. 7

5. W320-P41 rev. O (IFA draft date March 1995) Procurement Specification, Isokinetic Air Sampler Stack Monitor

6. 1985 ASHRAE Fundamenta7s

\subsection{CALCULATIONS}

\section{1 Stack Sizing}

Stack sizing was originally performed by offsite author based on 4" diameter stack, modeling the Exhaust Skid as a 9' tall building. The stack size was changed to

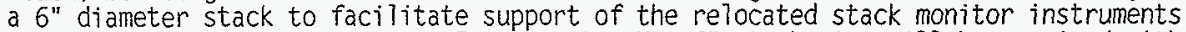
directly on the stack (see ref. 5. App. A). The 6" stack size will be examined with the same logic per ASHRAE Fundamentals (ref. 3) Chapter 14 information except a $6^{\prime}$ tall building air intake assumption shall be used instead of $9^{\prime}$ tall. The nearest building air intake is not close enough to warrant attention. The 6" stack has a 7 " diameter stack head (ref. 5).

The larger diameter stack size drops us below the recommended ASHRAE limit of $2000 \mathrm{fpm}$ since $180 \mathrm{cfm} /\left[(\mathrm{pi})(7 / 12)^{2} / 4\right]=674 \mathrm{fpm}$, and at $360 \mathrm{cfm}$ yields $1347 \mathrm{fpm}$. With a 


\section{DESIGN ANALYSIS}

Client WHC

Subject Exhaust Skid Stack Sizing \& Fan Sizing
Location 241-C/200 East

WO/JOD No. ER4319

$\begin{array}{ll}\text { Date } 3-28-95 & \text { By PH Langowski } \\ \text { Checked 3/28/45 } & \text { By Z. Pma } \\ \text { Revised } & \text { By }\end{array}$

7 mph wind speed (ref. 4) which equals (7) (5280)/60=616 fpm, we find that $V_{e}$ is not 1.5 times as high as the wind speed $U_{H}$. Using equation 24 , it is seen that the additional downwash height $h_{d}$, is equal to $(2.0)(7 / 12)(1.5)(1) 674 / 616=1.91 \mathrm{ft}$.

Using Equation 25, the plume rise, $h_{r}$, is calculated as $(3.0)(674 / 616)(7 / 12)=1.91$ ft. Equation 26 shows that $h_{\text {r }}$ and $h_{d}$ cancel each other out. The capped height of the stack above the fictional Exhaust skid building, $h_{s c}$. is therefore determined using Equations 1 and 5 with the $1: 5$ siope. From Equation $1, R=6.5^{0.67} 26^{0.33}=10.3 \mathrm{ft}$. From Equation $5, L_{r}=(1)(10.3)=10.3 \mathrm{ft}$. For the $1: 5$ sloping plume to not enter the recirculation region of Figure 3 , $h_{s c}$ must be greater than $(26.5+10.3) / 5=7.4 \mathrm{ft}$. The total stack height must therefore be greater than the sum of the height of the building ( $6 \mathrm{ft}$.$) and h_{\mathrm{sc}}$. Therefore, the total stack height must be greater than $6+7.4=13.4$ ft. This minimum stack height will yield a suitable design. Ref. 5 shows a total stack and head height of $20^{\prime}$.

\subsection{Exhaust fan sizing}

\begin{tabular}{|l|c|c|}
\hline From ref 2 calculation. the upstream pressure drops are as follows: \\
\hline condition & $\begin{array}{c}\text { minimum exhaust } \\
180 \mathrm{scfm}\end{array}$ & $\begin{array}{c}\text { maximum exhaust } \\
360 \text { scfm }\end{array}$ \\
\hline clean \& dry components & $18.6^{\prime \prime} \mathrm{w.g}$ & $24.4^{\prime \prime}$ W.g. \\
\hline dirty \& wet components & $33.9^{\prime \prime} \mathrm{w.g}$ & $34.5^{\prime \prime}$ W.g. \\
\hline
\end{tabular}

The pressure losses on the Exhaust Skid are estimated at 180 scfm as follows:

\begin{tabular}{|c|c|c|}
\hline component & reference & loss in. w.g. \\
\hline shutoff valve, $6^{\prime \prime}$ & $\begin{array}{l}\text { ref. } 6,7-5, c_{0}=0,50 \\
(180) /\left[(p i)(6 / 12)^{2} / 4\right]=917 \mathrm{fpm}, V_{n}=0.052\end{array}$ & $\begin{array}{l}(0.50)(0.052) \\
=0.026\end{array}$ \\
\hline electric heating coil & $\begin{array}{l}\text { ref } 2 \text {, similar to recirculation heating } \\
\text { coil }\end{array}$ & 0.060 \\
\hline transition to square & use $C_{0}=0.50$ & $\begin{array}{l}(0.50)(0.052) \\
=0.026\end{array}$ \\
\hline $\begin{array}{l}\text { inlet test section. } \\
24^{\prime \prime} \times 24^{\prime \prime}\end{array}$ & assumed negligible & 0.000 \\
\hline HEPA filter, $24^{\prime \prime} \times 24^{\prime \prime}$ & $\begin{array}{l}(180 / 1000)(1)=0.18 \text {, assumes } 1000 \mathrm{cfm} \text { size } \\
\text { filter }\end{array}$ & 0.18 \\
\hline $\begin{array}{l}\text { combination test section. } \\
24^{\prime \prime} \times 24^{\prime \prime}\end{array}$ & assumed negligible & 0.000 \\
\hline
\end{tabular}




\section{DESIGN ANALYSIS}

Client WHC

Subject Exhaust Skid Stack Sizing \& Fan Sizing

Location 241-C/200 East

\begin{tabular}{|c|c|c|}
\hline HEPA filter, $24 " \times 24 "$ & $\begin{array}{l}(180 / 1000)(1)=0.18 \text {, assumes } 1000 \mathrm{cfm} \text { size } \\
\text { filter }\end{array}$ & 0.18 \\
\hline $\begin{array}{l}\text { outlet test section, } \\
24^{\prime \prime} \times 24^{\prime \prime}\end{array}$ & assumed negligible & 0.000 \\
\hline transition to round & assumed negligible & 0.000 \\
\hline shutoff valve, 6" & $\begin{array}{l}\text { ref. } 6,7-5, C_{0}=0.50 \\
(180) /\left[(p i)(6 / 12)^{2} / 4\right]=917 \text { fpm, } V_{0}=0.052\end{array}$ & $\begin{array}{l}(0.50)(0.052) \\
=0.026\end{array}$ \\
\hline stack \& duct misc. . 6" & $20^{\prime}\left(0.3^{\prime \prime}\right.$ w.g. $\left./ 100^{\circ}\right)$ & 0.060 \\
\hline stack head, 7" & ref. $3, S D 2-6, C_{0}=1.00$ & 0.052 \\
\hline & & total 0.610 \\
\hline
\end{tabular}

$18.6+0.6=19.2 "$ w.g. at $180 \mathrm{scfm}$ (clean \& dry). Round down to $19 "$ for use in ref. 1.

The pressure losses on the Exhaust Skid are estimated at $360 \mathrm{scfm}$ as follows:

\begin{tabular}{|c|c|c|}
\hline component & reference & loss in. w.g. \\
\hline shutoff valve. $6^{\prime \prime}$ & $\begin{array}{l}\text { ref. } 6,7-5, C_{0}=0.50 \\
(360) /\left[(\mathrm{pi})(6 / 12)^{2} / 4\right]=1833 \mathrm{fpm}, V_{n}=0.210\end{array}$ & $\begin{array}{l}(0.50)(0.210) \\
=0.105\end{array}$ \\
\hline electric heating coil & $\begin{array}{l}\text { ref. } 2 \text {, similar to recirculation heating } \\
\text { coi } 1 \text {, use } 0.100 \text { as heating coil sized for } \\
\text { variable flow will probably have a higher } \\
\text { pressure drop than normal at the high } \\
\text { end. }\end{array}$ & 0.100 \\
\hline transition to square & use $C_{o}=0.50$ & $\begin{array}{l}(0.50)(0.210) \\
=0.105\end{array}$ \\
\hline $\begin{array}{l}\text { inlet test section. } \\
24^{\prime \prime} \times 24^{\prime \prime}\end{array}$ & assumed negligible & 0.050 \\
\hline HEPA filter. $24^{\prime \prime} \times 24^{\prime \prime}$ & filter loaded to $4^{\prime \prime}$ w.g. & 4.000 \\
\hline $\begin{array}{l}\text { Combination test section. } \\
24 " \times 24^{\prime \prime}\end{array}$ & assumed negligible & 0.050 \\
\hline HEPA filter, $24 " \times 24 "$ & $\begin{array}{l}\text { filter loaded to 2" w.g. (note that the } \\
\text { project documentation shows that the } \\
\text { maximum allowable across both filters is } \\
5.9^{\prime \prime} \text { W.g.) }\end{array}$ & 2.000 \\
\hline $\begin{array}{l}\text { outlet test section. } \\
24^{\prime \prime} \times 24^{\prime \prime}\end{array}$ & assumed negligible & 0.050 \\
\hline
\end{tabular}

KEH 0037.00 (06/92) KEF055

HNF-2483, Rev. 0

Page $\mathrm{H}-4$ 


\section{DESIGN ANALYSIS}

Client WHC

Subject Exhaust Skid Stack Sizing \& Fan Sizing

Location 241-C/200 East
WO/JOb No. ER4319

Date 3-28-95

Checked $3 / 28 / 45$

Revised $2 / 13 / 96$
Calc. No. W320-K-011

Revision 0

Page No. 4 of 5

\begin{tabular}{|c|c|c|}
\hline transition to round & assumed negligible & 0.000 \\
\hline shutoff valve, $6 "$ & $\begin{array}{l}\text { ref. } 6,7-5, c_{0}=0.50 \\
(360) /\left[(p i)(6 / 12)^{2} / 4\right]=1833 \text { fpm, } V_{0}=0.210\end{array}$ & $\begin{array}{l}(0.50)(0.210) \\
=0.105\end{array}$ \\
\hline stack \& duct misc., 6" & $20^{\prime}\left(1.0^{\prime \prime}\right.$ w.g./100') & 0.200 \\
\hline stack head, 7" & ref. $3, S D 2-6, C_{0}=1.00$ & 0.210 \\
\hline & & total 6.975 \\
\hline
\end{tabular}

$34.5+7.0=41.5$ " W.g. at $360 \mathrm{scfm}$ (dirty. wet). Round up to 42 " for use in ref. 1 .

The brakehorspower required is estimated based on vendor data (App. A) of fan operating at $360 \mathrm{acfm}$ at $40.8^{\prime \prime} \mathrm{W} . \mathrm{g}$. at $140 \mathrm{~F}$ \& density $=0.0644$ (309 scfm at density=0.075). The 5.95 bhp with a $90 \%$ efficiency motor is equivalent to a $6.61 \mathrm{hp}$ motor requirement. A $7.5 \mathrm{hp}$ nameplate motor should be sufficient.

\subsection{Exhaust heating coil sizing, $60 \%$ relative humidity}

The norma 7 maximum heating coil size would be required for the case of 360 scfm entering air at $40 \mathrm{~F}$ saturated and the design exiting condition of $60 \%$ relative humidity at $53 \mathrm{~F}$ (see psychrometric chart, App. A). The enthalpy change between these two states is $18.3-15.3 \mathrm{Btu} / 7 \mathrm{~b}_{\mathrm{do}}=3.0 \mathrm{Btu} / 7 \mathrm{~b}_{\mathrm{dg}}$. At the entering density of $12.696 \mathrm{ft}^{3} / 7 \mathrm{~b}_{\mathrm{da}}$ this yields $(360 \mathrm{scfm})\left(3.0 \mathrm{Btu} / \mathrm{ib}_{\mathrm{da}}\right) /\left(12.696 \mathrm{ft}^{3} / 7 \mathrm{~b}_{\mathrm{da}}\right)=85.07 \mathrm{Btu} / \mathrm{min}(5104 \mathrm{Btu} / \mathrm{h}$, or 1.5 $\mathrm{KW}$ ).

The maximum upset heating coil size would be required for the case of 360 scfm entering air at $120 \mathrm{~F}$ saturated and the design exiting condition of $60 \%$ relative humidity at $139 \mathrm{~F}$ (see psychrometric chart. App. A). The enthalpy change between these two states $i s^{2} 131-119.5 \mathrm{Btu} / 1 \mathrm{~b}_{\mathrm{sa}}=11.5 \mathrm{Btu} / 1 \mathrm{~b}_{\mathrm{da}}$. At the entering density of 16.519 $\mathrm{ft}^{3} / 1 \mathrm{~b}_{\mathrm{da}}$, this yields $(360 \mathrm{scfm})\left(11,5 \mathrm{Btu} / 1 \mathrm{~b}_{\text {da }}\right) /\left(16.519 \mathrm{ft}^{3} / 1 \mathrm{~b}_{\mathrm{da}}\right)=250.06 \mathrm{Btu} / \mathrm{min}(15.037$ $B t w / h$, or $-4.4 \mathrm{KW}$ ).

$$
5.5
$$

119.86

7,192

$$
2.1
$$

HNF-2483, Rev. 0

Page H-5 


\section{DESIGN ANALYSIS}

Client WHC

Subject Exhaust Skid Stack Sizing \& Fan Sizing

Location 241-C/200 East
Calc. No. $\$ 320-\not K-011$

Revision 0

Page No. 5 of 5

WO/Job No. ER4319

Date 3-28-95

Checked $3 / 28 / 45$

Revised $2 / 13 / 96$
By PH Langowski

By $\lambda_{0}$ Pre

By Damuy 5 gry

\subsection{FINDINGS \& CONCLUSIONS} adequate.

The Exhaust Skid stack sizing of $20^{\circ}$ total (including stack head) will be

The Exhaust Skid fan will be required to be selected for the following pressure loss conditions. The fan motor wi11 be required to be approximately $7.5 \mathrm{hp}$.

\begin{tabular}{|l|c|c|}
\hline & $\begin{array}{c}\text { minimum exhaust } \\
180 \mathrm{scfm}\end{array}$ & $\begin{array}{c}\text { maximum exhaust } \\
360 \mathrm{scfrin}\end{array}$ \\
\hline design condition & $19^{\prime \prime} \mathrm{w.g.}$ & $42^{\prime \prime}$ w.g. \\
\hline
\end{tabular}

The Exhaust Skid heating coil will be approximately $1.5 \mathrm{KW}$ under normal operating conditions. In the upset condition, 24.4 KW will be required. The heating coil with SCR control shall be capable of operating across a power range up to $-4.4 \mathrm{~kW}$.

$$
\text { 2. KW }
$$

HNF-2483, Rev. 0

Page $\mathrm{H}-6$ 
APPENDIX A

HNF-2483, Rev. 0

Page H-7

$\frac{2 H+23-2895}{R / 14 / 45}$ 


\section{AIRFLOW AROUND BUILDINGS}

Flow Patterns $\ldots . \ldots \ldots \ldots \ldots \ldots \ldots \ldots \ldots \ldots . . \ldots \ldots .14$

Wind Pressures on Buildings $\ldots \ldots \ldots \ldots \ldots \ldots \ldots \ldots . .14 .3$

Wind Effecis on System Operation $\ldots \ldots \ldots \ldots \ldots \ldots 14.8$

Building Internal Pressure and Flow Control . . . . . . . 14.9

Almospheric Dispersion of Building Exhaust ......... 14.9
Estimating Intake Contamination ...............14.10

Exhaust Stack Design .......................14.11

Heat Rejection Equipment .....................14.15

Scale Model Simulation and Testing $\ldots \ldots \ldots \ldots \ldots \ldots 14.15$

Symbols ............................14.16
A IRFLOW around buildings affects worker safety, process and building equipment operation, weather and pollution protection at inlets, and the ability to control environmenial factors of iemperature, humidity, air motion, and contaminants. Wind causes surface pressures that vary around buildings, changing intake and exhaust system flow raies, natural ventilation, infiltration and exfiluation, and interior pressure. The mean flow patterns and turbulence of wind passing over a building can cause a recirculation of exhaust gases to air intakes. This chapier contains information for evaluating flow patterns, estimating wind pressures and air intake contamination, and solving problems caused by the effects of wind on intakes, exhausts, and equipment. Related information can be found in Chapters $11,13,23$, and 24 of this volume; in Chapters 25, 27, and 47 of the 1991 Applications volume; and in Chapters 26, 31, 36, and 37 of the 1992 Systems and Equipment volume.

\section{FLOW PATTERNS}

Buildings of an even moderately complex shape, such as L-or U-shaped structures formed by two or three rectangular blocks, can generate flow patierns too complex to generalize for design. To determine flow conditions influenced by surrounding buildings: or iopograpby, a wind tunnel or water channel test of scale models or tests of existing buildings are required. However, if a building is oriented perpendicular to the wind, it can be considered as consisting of several independent rectangular blocks. Only isolated rectangular block buildings will be discussed here. Hosker (1984, 1985) reviews the effects of nearby buildings.

The mean speed of wind approaching a building increases with height above the ground (Figure 1). Both the upwind velocity pro. file shape and its turbulence level strongly influence flow patterns and surface pressures. A stagnation zone exists on the upwind wall. The flow separates at the sharp edges to generate recirculating flow zones that cover the downwind surfaces of the building (roof, sides, and leeward walls) and extend for some distance into the wake. If the building has sufficient length $L$ in the windward direction, the flow will reattach to the building (Figure 2 ) and may generate two distinct regions of separated recirculating flow-on the building and in its wake.

Surface flow patterns on the upwind wall are largely influenced by approach wind characteristics. Higher wind speed at roof level causes a larger stagnation pressure on the upper part of the wall than near the ground, which leads to downwash on the lower onehalf to two-thirds of the building (Figure 1). On the upper onequarter to one-third of the building, the surface flow is directed upward over the roof. For a building whose height $H$ is three or times the width $W$ of the upuind face, an intermediate zone - exist between the upwash and downwash regions, where the surface streamlines pass horizontally around the building. The

The preparation of this chapler is assigned to TC 2.5, Air Flow Around Busileings downwash on the lower surface of the upwind face separates from the building before it reaches ground level and moves upwind to form a vortex that can generate high velocities close to the ground. This ground level upwind vortex is carried around the sides of the building in a $U$ shape (Figure $1 b$ ) and is responsible for the suspension of dust and debris that can contaminate air intakes close to ground level.

\section{Recirculation and High Turbulence Regions}

For wind perpendicular to a building wall, the height $H$ and width $W$ of the upwind building face determine the flow patterns shown in Figure 3. According to Wilson (1979), the scaling length $R$ which combines these dimensions is:

$$
R=B_{s}{ }^{0.67} B_{L}{ }^{0.33}
$$

where $B_{s}$ is the smaller and $B_{L}$ the larger of the dimensions $H$ and W. When $B_{L}$ is larger than $8 B_{s}$, use $B_{L}=8 B_{s}$ in Equation (1). For buildings with varying roof levels or with wings separated by at least a distance $B_{s}$, only the height and width of the building face below the portion of the roof in question should be used to calculate $R$. Wilson (1976) indicates that for a flat-roofed building, the recirculation region maximum height $H_{c}$, at location $X_{c}$, and reattachment lengths $L_{c}$ and $L_{r}$ shown in Figures 3 and 17 are:

$$
\begin{aligned}
& H_{c}=0.22 R \\
& X_{c}=0.5 R \\
& L_{r}=0.9 R \\
& L_{r}=1.0 R
\end{aligned}
$$

The downwind boundary of the rooftop recirculation region may be approximated by a straight line sloping downward from $H_{c}$ to the roof at $L_{c}$. The dimensions of the recirculation zones are somewhat sensitive to the intensity and scale of turbulence in the approaching wind. High levels of iurbulence from upwind obstacles may decrease the coefijcients in Equations (2) through (5) by up to a factor of 2 . Turbulence in the recirculation region and in the approaching wind also causes the reattachment locations on Figure 2 to fluctuate.

To account for changes in roof level, penthouses, and equipment housings and enclosures, the scaling length $R$ of each of these obstacles should be calculated from Equation (1) using the dimensions of the upwind face of the obstacle. The recirculation region for each obstacle may be calculated from Equations (2), (3), and (4). The length $L_{r}$ of the recirculation region downwind from the obstacle, or from the entire building, is given by Equation (5), with $R$ based on the dimensions of the downwind face of the obstacle. The high turbulence region boundary $Z_{2}$ in Figure 17 follows a 1:10 $\left(5.7^{\circ}\right)$ downward slope from the top of the recirculation regions at $X_{6}$ or $L_{r}$. When an obstacle is close to the 


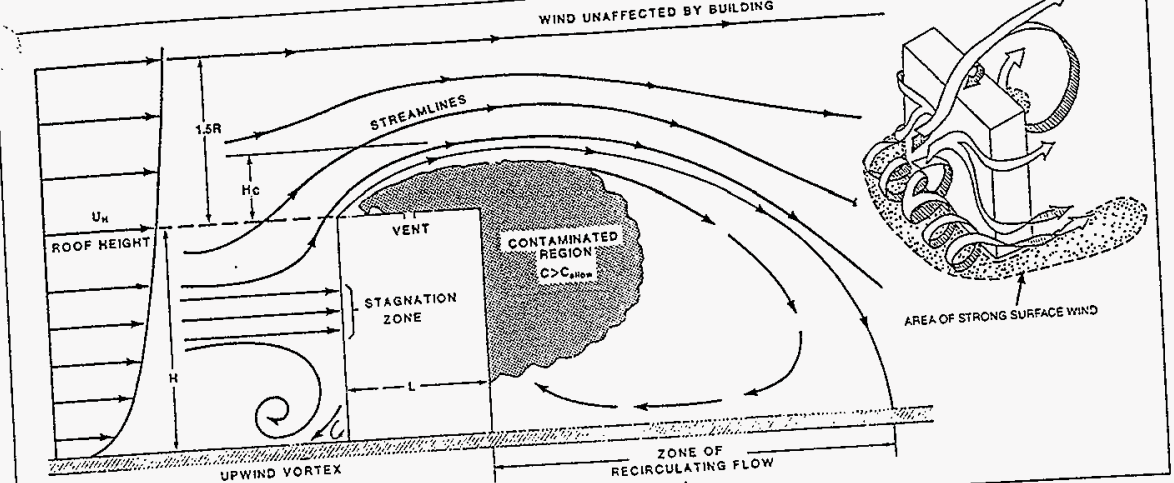

Fig. 1 Flow Patterns around Rectangular Building
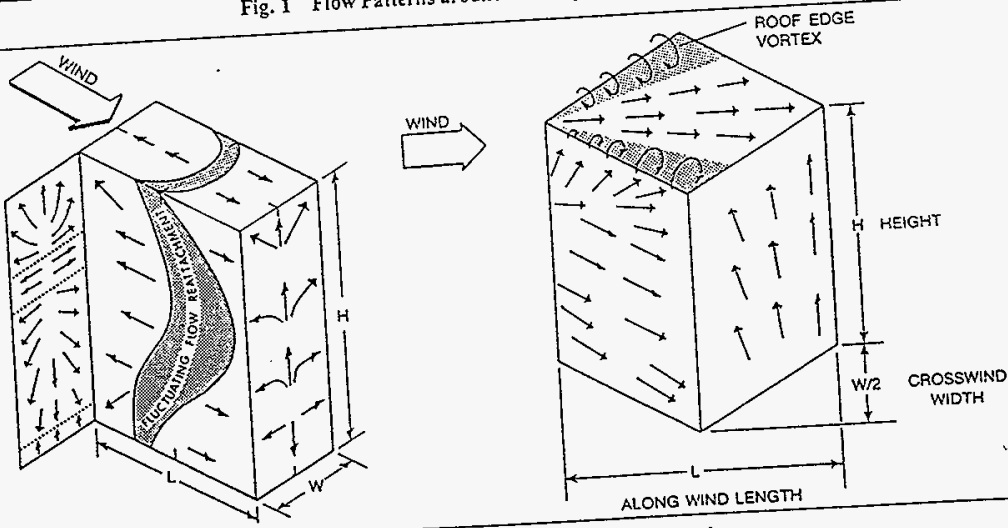

Fig. 2 Surface Flow Patterns and Building Dimensions

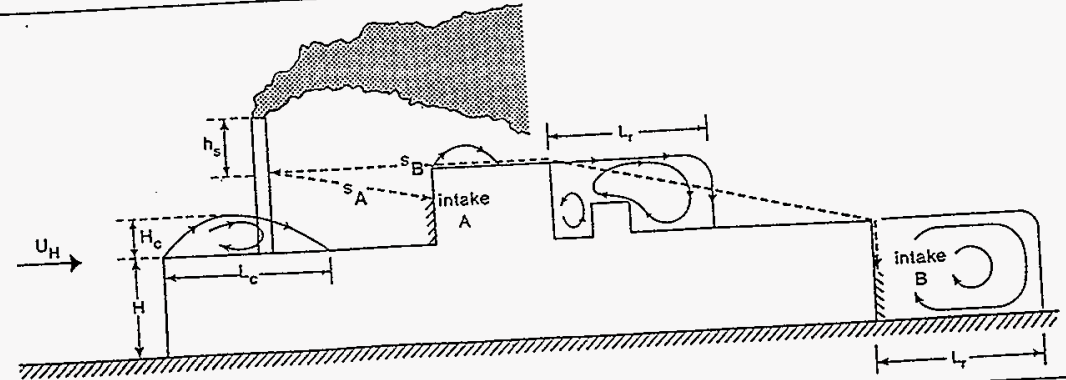

Fig. 3 Flow Recirculation Regions and Exhaust to Intake Stretched String Distances (wilson 1982$) 0$ fth $3-28-9$ $A 2 \quad 20$ 
1.ind directions, when the exhaust is uncapped $(\beta=1)$ and $\because \checkmark U_{H}>0.5$. A value of $B_{1}=0.0204$ should be used if $V_{c} / U_{H}$ : 5 or the stack is capped $(\beta=1)$ and the wind is at $45^{\circ}$ to the upwind wall, or if there is no significant atmospheric turbulence, for example, at roof level of high-rise buildings, or in flat rural surroundings [Wilson and Chui (1987), Chui and Wilson (1988)].

Equations (19), (20), and (21) imply that minimum dilution does not depend on the location of either the exhaust or intake, only on the distance $S$ between them. This is true when exhaust and intake locations are on the same building wall or on the roof. The dilution may increase if the intake and exhaust are located on different faces, as indicated by the $M$ factor in Equation (18). For roof exhausts with wall intakes, the results of $\mathrm{Li}$ and Meroney (1983) suggest that $B_{1} \cong 0.20$ in Equation (21).

For buildings less than about $330 \mathrm{ft}$ high and also less than twice as high as the surrounding buildings, atmospheric turbulence makes a significant contribution to exhaust gas dilution. Wilson $(1976,1977)$ gives surface concentration contours for flat-roofed buildings in a simulated approach wind typical of an urban area. Flush vents with small exhaust velocity make these results sujiable for estimates for capped exhaust stacks or lowvered exhaust vents.

The effect of atmospheric turbulence is relatively insignificant for high-rise buildings taller than $330 \mathrm{ft}$ and also iwice the average building height for $3000 \mathrm{ft}$ upwind. On these high-rise buildings, where the effects of atmospheric turbulence are small, Wilson and Chui (1987) found that maximum surface concentra. tions for 10-min exposures were two to ten times higher than on an equivalent low-rise building. A dilution coefficient of $B_{1}=0.02$ should be used for high-rise buildings.

When exhaust from several collecting stations is combined in a single vent or in a tight cluster of stacks, the effective exhaust area $A$, will increase, causing the minimum dilution in tation (19) to decrease. To qualify as a cluster, the stacks must all lie within a two-stack diameter radius of the middle of the. group. Stacks lined up in a row do not act as a single stack, as shown by Gregoric et ol. (1982). However, the exhaust concentration $C_{e}$ of each contaminant will decrease by mixing with other exhaust streams, and the plume rise will increase due to the higher momentum in the combined jets. For combined vertical exhaust jets, the roof level intake concentration $C$ in Equation (12) will almost always be lower than the intake concentration caused by separate exhausts. Where possible, exhausts should be combined before release to take advantage of this increase in overall dilution.

\section{Critical Wind Speed and Dilution}

At very low wind speed, the exhaust jet from an uncapped stack will rise high above roof level, producing a large exhaust dilution $D_{\min }$ at a given intake location. Likewise, at high wind speed, the dilution will also be large because of the longitudinal stretching of the plume by the wind. Between these extremes, a critical wind speed exists at which the least dilution will occur for a given exhaust and intake location. This critical, absolute minimum dilution $D_{\text {reir }}$ may be used to determine if an exhaust yent will be safe 1. under all wind conditions. The critical wind speed for an uncapped vertical exhaust $(\beta=1.0)$ can be evaluated by finding the absolute minimum in Equations (19), (20), and (21). It is closely approximated by

$$
U_{\text {crit }, 0} / V_{e}=2.9 B_{1}-0.33\left(S / A_{e} e^{0.5}\right)^{-0.67}
$$

"re $U_{\text {crito }}$ is the critical wind speed producing the smallest Anum dilution for an uncapped vertical exhaust with negligible stack height. This critical dilution $D_{\text {crit.o }}$ may be found by using Equation (22) in Equation (19). For $S / A_{e}{ }^{0.5}>5$, this minimum is closely approximated by

$$
D_{\text {crit.o }}=1+7.0 B_{1}^{0.67}\left(S / A_{e}^{0.5}\right)^{1.53}
$$

The critical dilution in Equation (23) depends only on distance from the exhaust and not on the exhaust velocity $V_{e}$. However, increasing the exhaust velocity increases the critical wind speed in Equation (22), usually causing this worst-case critical dilution to occur less frequently.

To assess the severity of the hazard caused by intake contamination, it is useful to know how often the worst case $D_{\text {cri }}$ is likely to occur. The number of hours per year during which the dilution is no more than a factor of 2 higher than the critical minimum value may be estimated from weather records by finding the fraction of time that the wind speed lies in the range from $0.5 U_{\text {crit,o }}$ to $3.0 U_{\text {crino }}$ (Wilson 1982, 1983). This fraction is then multiplied by the fraction of time the local wind direction lies in a sector $\pm 22.5^{\circ}$ on each side of the line joining the exhaust and intake location.

\section{EXHAUST STACK DESIGN}

Before discharge, exhaust contamination should be reduced by fjlters, collectors, and scrubbers. Central exhaust systems that combine flow's from many collecting stations should always be used where safe and practical. By combining several exhaust streams, central systems dilute intermittent bursts of contamination from a single station. However, in some cases, separate exhaust systems are mandatory. The nature of the contaminants to be combined, the recommended industrial hygiene practice, and the applicable safety codes need to be considered. Halitsky (1966) and Briggs (1984) present methods for estimating the trajectory of jets and the subsequent dispersion of jet plumes.

Separate exhaust stacks should be grouped in a tight cluster to take advantage of the larger plume rise of the resulting combined jet. In addition, a single stack from a central exhaust system or a tight cluster of stacks allow's building air intakes to be placed as far as possible from the exhaust location. As shown in Figure 3, the effective stack height $h_{s}$ is the porion of the exhaust stack that extends above local recirculation zones and upwind and dowrwind obstacles. Wilson and Winkel (1982) demonsirated that stacks terminating below the level of adjacent walls and architectural enclosures do not effectively reduce roof-level exhaust contamisation. To take full advantage of their height, stacks should be located on the highest roof of a building. Where architectural enclosures are used to mask rooftop equipment, stacks must extend above the height $H_{c}$ of the flow recirculation zone over the enclosure to prevent exhaust contamination of equipment within the enclosure.

\section{Required Stack Exhaust Velocity}

High stack discharge velocity and temperature increase plume rise and reduce intake contamination by increased jet dilution and by the elevated plume trajectory. However, high discharge velocity is a poor substitute for increased stack height.

As shown in Figure 15, stacks should have vertically directed uncapped exhaust jets. Stack caps which deflect the exhaust jet have a detrimental effect on both minimum dilution and critical uind speed. In any case, conical stack caps often do not eliminate rain, because rain does not usually fall straight down. Changnon (1966) shows that periods of heavy rainfall are often accompanied by high winds that deflect the raindrops under the cap and into the stack. A stack velocity of about 2500 fpm prevents condensed moisture from draining down the stack and keeps rain from entering the stack. Even when there are drains in the stack, the exhaust velocity should be mainiained above $2000 \mathrm{fpm}$ to provide adequate plume rise and jet dilution. Where stack condensate is corrosive, the body of the stack should be sized for a velocity of $1000 \mathrm{fpm}$, I

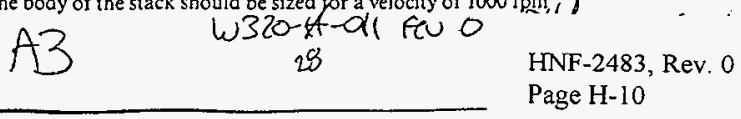


or less, and a drain provided for the condensate (Anonymous 1964). The stack tip should have a converging cone (Figure isB) to provide the required high-velocity discharge of 2000 to 3000 fpm. For intermittently operated systems, protection from rain and snow should be provided by stack drains as shown in Figures ISF through $15 \mathrm{~J}$.

\section{Stack Height to Avoid Exhaust Entrainment}

To avoid entrainment of exhaust gases into the wake, stacks must terminate above the flow recirculation height $H_{s}$. Where stacks or exhaust vents discharge within this recirculation region,

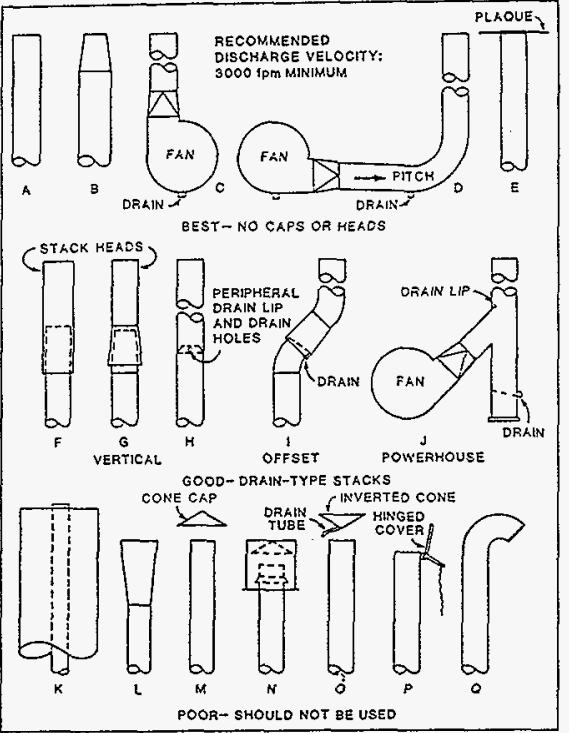

Fig. 15 Stack Designs Providing Vertical Discharge and Rain Protection gases rapidly diffuse to the roof and may enter ventilation intakes or other openings. Figure 1 show's that this effluent will flow into the zone of recirculating flow behind the downvind face and will, in some cases, be brought back up onto the roof.

A high velocity exhaust with $\nu_{e}$ at least 1.5 times as large as the wind speed $U_{H}$ at roof height is essential not only to provide good initial dilution near the stack, but also to avoid stack wake downwash, which can reduce or eliminate plume rise. Downwash of the exhaust into the stack wake, shown in Figure 16, is caused by the low-pressure region which develops in the wake on the lee side of the stack. In situations where exhaust velocity cannot be maintained at a value larger than 1.5 times the wind speed, an additional downuash height $h_{d}$ (see Figure 16) should be added to the stack height $h_{s}$. For a vertically directed jet from an uncapped stack $(\beta=1.0)$, Briggs (1973) recommends

$$
h_{\ell}=2.0 d\left(1.5 \beta V_{\epsilon} / U_{H}\right)
$$

for $V_{c} / U<1.5$, where $d=\left(4 A_{e} / \pi\right)^{0.5}$ is the effective stack diameter. Rain caps are frequently used on stacks of gas-and oil-fired furnaces and package ventilation units. These units will have $\hat{\beta}=0$, so $h_{d}=3.0 d$, and this should be added to the nominal height $h_{s}$ to avoid flue gas contamination of roof-mounted equipment and air intakes.

The design procedure for selecting an appropriate stack height starts by calculating the height $h_{s c}$ of a stack with a rain cap and, therefore, no plume rise. For an uncapped vertical exhaust, the minimum rise $h$, of the bent-over exhaust jet is estimated, and the

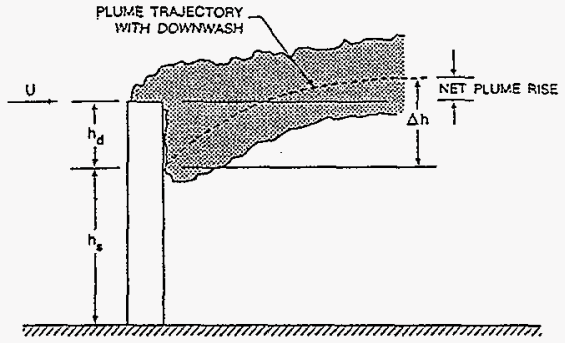

Fig. 16 Reduction of Effective Stack Height by Stack Wake Downwash

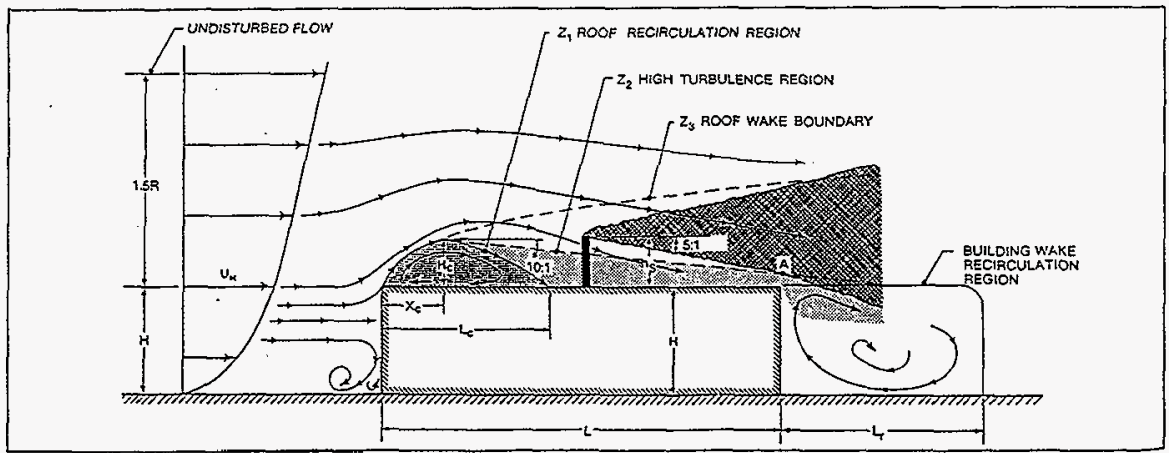

Fig. 17 Design Procedure for Required Stack Height to Ayoid Contamination

(Wilson 1979)<smiles>CC1CC1C1(C)CC1C</smiles>

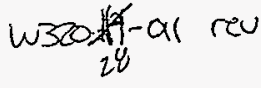

, n

HNF-2483, Rev. 0

Page $H-11$ 
capped height $h_{s c}$ is lowered by an amount $h$, to give credit for plume rise (see Figure 16).

The capped stack height $h_{s c}$ required to avoid excessive exhaust gas reentry is estimated by assuming that the plume spreads upward and downward from $h_{s c}$ with a $1: 5$ slope $(11.3 \%$, as shown in Figure 17. The first step is to raise the capped height $h_{s c}$ until the lower edge of the 1:5 sloping plume avoids contact with all recirculation (zone 1) boundaries on rooftop obstacles such as air intake housings, architectural screens, or penthouses. The size of these recirculation zones, shown in Figures 3 and 17, are calculated using Equations (2), (3), and (4).

If air intakes are located on the downwind wall, the lower edge of the plume, sloping down at $1: 5$, must lie above the downwind edge of the roof when a nontoxic exhaust contaminant, such as an odor or water vapor, is being dealt with. For a toxic contaminant that requires a large dilution factor at the wall intake, the lower edge of the plume should lie above the flow recirculation zone in the wake downwind of the building. The boundary of the building wake recirculation, shown in Figures 1, 3, and 17, is defined by a horizontal line extending a distance $L$, from the downwind edge of the roof. The recirculation length $L$, is calculated from Equation (5).

For an uncapped stack, the plume rise $h_{r}$ due to the vertical momentum of the exhaust is estimated from Briggs (1984) as

$$
h_{r}=3.0\left(V_{e} / U_{H}\right) d
$$

where the wind speed $U_{H}$ is the maximum design wind speed for which air intake contamination must be avoided. The required height $h_{s}$ of the uncapped stack extending above local recircula. tion zones and obstacles is

$$
H_{S}=h_{S C}-h_{f}+h_{d}
$$

If the minimum recommended exhaust velocity of $V_{e}=1.5 U_{H}$ is maintained, plume downwash $h_{d}=0$, and $h_{r}=4.5 d$; thus, an uncapped stack can be made $4.5 d$ shorter than a capped one.

The largest flow recirculation, high turbulence, and wake regions occur when wind is normal to the upwind wall of the building. Required stack heights should be the largest of the heights determined for all four directions for which the wind is normal to a building wall.

\section{Estimating Critical Dilution for Exhaust Stacks}

The geometric design for avoiding excessive contamination does not give any estimate of the worst case critical dilution factor $D_{\text {crit }}$ between the stack and an air intake. In this section, $D_{\text {crit }}$ will be estimated for a predetermined stack height.

An increase in stack height or in exhaust velocity ratio $\nu_{e} / U_{H}$ reduces roof-level contamination by keeping the high concentrations on the plume centerline far enough above the roof so that the intakes see only intermittent concentrations in the fringes of the plume In addition, stack height or high exhaust velocity increases the critical wind speed at which the absolute minimum dilution occurs. This higher critical wind speed often reduces sigtificantly the number of hours per year that high intake contamination (i.e, low dilution) will be observed.

Using a Gaussian plume dispersion equation, with a plume spread standard deviation of $0.14 S$, and an uncapped vertical exhaust jet with no buoyancy and with plume rise inversely proportional to wind speed, the critical wind speed $U_{\text {cril }}$ at which the smallest minimum dilution $D_{c r i}$ observed is

$$
\frac{U_{\text {crido }}}{U_{\text {crit }}}=(Y+1)^{0.3}-Y^{0.5}
$$

where $U_{\text {crit, }}$ is the critical wind speed for a flush (zero stack height) vertical exhaust, computed from Equation (22). The influence of stack height on the worst case critical dilution for the standard 10-min exposure time may be calculated from

$$
\frac{D_{\text {crit }}}{D_{\text {crito }}}=\frac{U_{\text {crit }}}{U_{\text {crito }}} \exp \left[Y+Y^{0.5}(Y+1)^{0.5}\right]
$$

where $Y=12.6\left(h_{s} / S\right)^{2}$, and $D_{\text {crios }}$ is the dilution at critical wind speed for a flush vertical roof exhaust with no stack height, from Equation (23). Equations (27) and (28) are reliable only for $Y<$ 2.0. Close to the stack, where $Y>2.0$, use $Y=2.0$ in Equations (27) and (28). Because both wind speed and turbulence intensity vary strongly with height above the building roof, the plume rise of the exhaust jet may not be inversely proportional to wind speed; normally its behavior is between $\Delta h \alpha U^{-0.4}$ and $U^{-1.0}$. Thus, Equations (27) and (28) are only approximations. Because buoyancy is not included, the added rise due to buoyarcy provides a factor of safety, particularly at low wind speed.

Because Equations (27) and (28) give the effect of a stack relative to a flush exhaust with $h_{s}=0$, they are useful for assessing the advantages of increasing stack height as a remedial measure. By comparing two different heights, this calculation allow's the relative benefits of a stack to be estimated without knowing any details of the contaminant concentrations or exhaust velocity in the existing stack. For example, the stack height required using the simple geometrical design procedure in the following section will have $h_{s} / S$ of at least 0.2. Equations (27) and (28) show that the critical wind speed $U_{\text {rft }}$ for this stack height will be about a factor of 2 larger, and the critical dilution $D_{\text {trir }}$, about eight times more than for the verical jet from an uncapped exhaust with zero effective stack height.

Example 1. The stack height $h_{s}$ of the uncapped vertical exhaust on the building shown in Figuse 3 must be specified to avoid excessive contamiration of air intakes $A$ and $B$ by stack gases. The stack has a diameter $d$ of $1.64 \mathrm{ft}$ and an exhaust velocity $V_{\text {e }}$ of $1770 \mathrm{fpm}$. It is located $52.5 \mathrm{ft}$ from the upwind edge of the roof. The penthouse has its upwind wall (with intake A) located 98.4 ft from the upwind edge of the roof, a height of $13.1 \mathrm{ft}$, and a length of $23.0 \mathrm{ft}$ in the wind direction. The top of intake $A$ is $6.56 \mathrm{ft}$ below the penthouse roof. The building has a height $H$ of 49.2 $\mathrm{ft}$ and a length of $203 \mathrm{ft}$. The top of intake $B$ is $19.7 \mathrm{ft}$ below roof level. The width (measured into the page) of the building is $164 \mathrm{ft}$, and the penthouse is $29.5 \mathrm{ft}$ wide. What are the required stack heights $h_{s}$ for both nontoxic and highly toxic exhaust contaminants for a design wind speed specified at a factor of 2 higher than the annual average hourly wind speed of 9.32 mph at a nearby airport with anemometer height $H_{\text {ref }}$ of $32.8 \mathrm{ft}$ ? The building is located in unshielded suburban terrain.

Solution: The first step is to set the height $h_{s c}$ of a capped stack by projecting lines with $S: 1$ slopes upwind from points of potential plume impact. For intake A, the highest point of impact is the top of the recirculation zone on the roof of the penthouse. To find the height of this recirculation zone, statt with Equation (1).

$$
R=(13.1)^{0.67}(29.5)^{0.33}=17.2 \mathrm{ft}
$$

Then use Equations (2) and (3):

$$
\begin{aligned}
& H_{c}=0.22(17.2)=3.77 \mathrm{ft} \\
& X_{c}=0.5(17.2)=8.60 \mathrm{ft}
\end{aligned}
$$

With the 5:1 slope of the lower plume boundary shown in Figure 17, the capped stack in Figure 3 must be

$$
h_{s c}=0.2(98.4-52.5+8.60)+3.77=14.7 \mathrm{ft}
$$

above the penthouse roof to avoid intake $A$. For intake $B$ on the downwind wall, the plume boundary from the stack in Figure 3 must lie above the end of the roof for nontoxic exhaust gas or the end of the building flow recirculation zone for highly toxic exhaust gas. For this tecirculation zonc, from Equation (j):

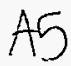




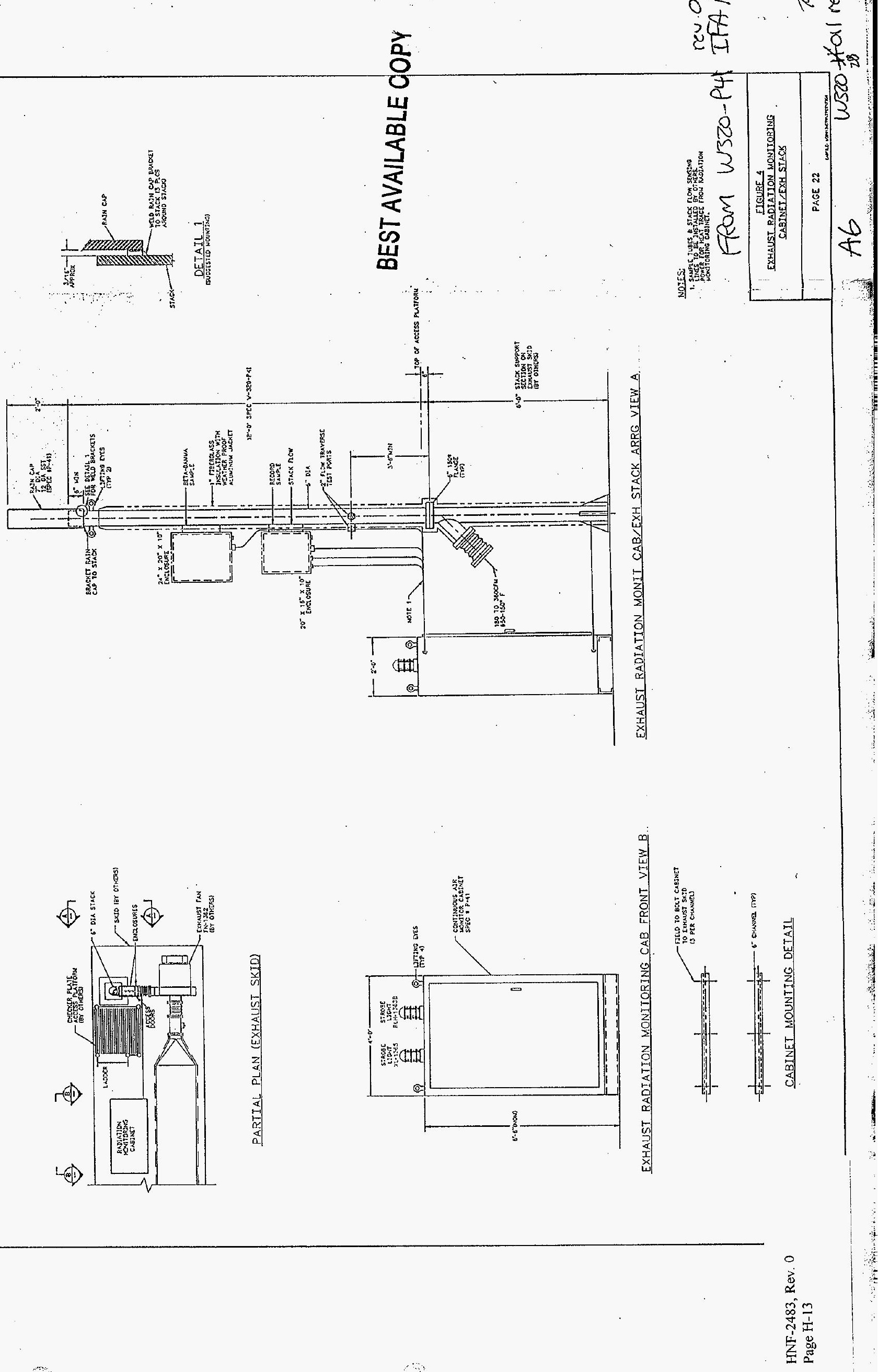




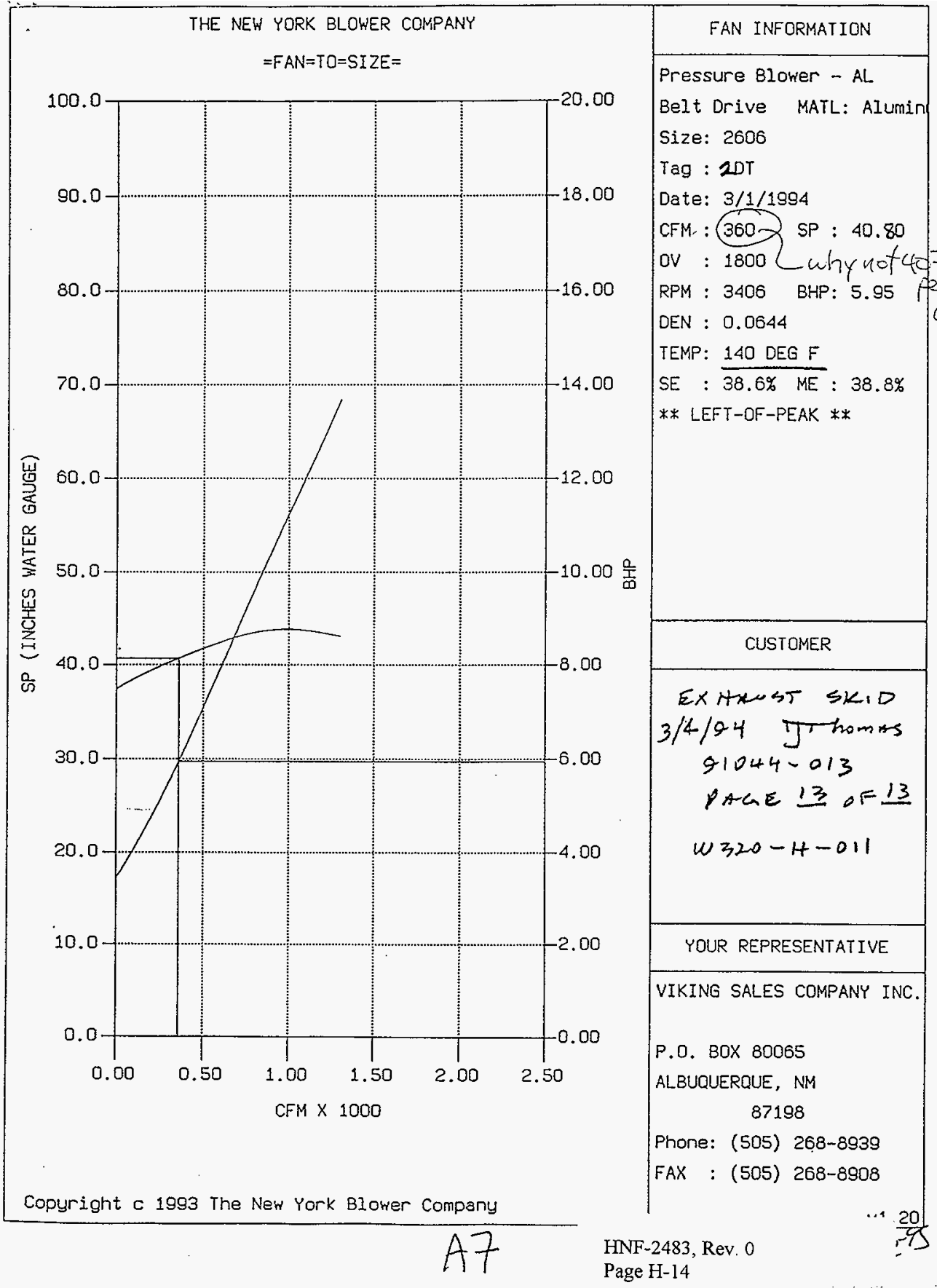



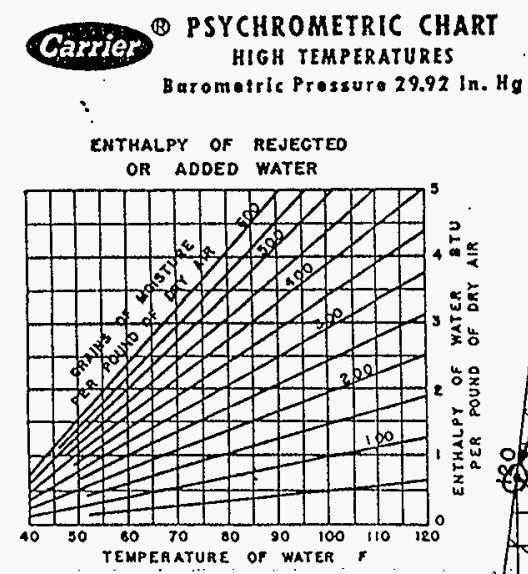

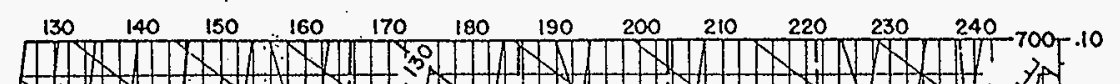

4 An

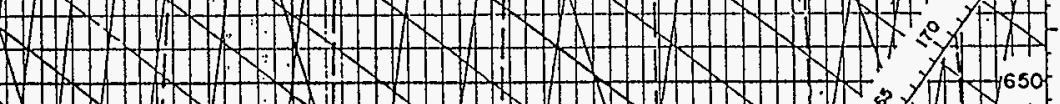

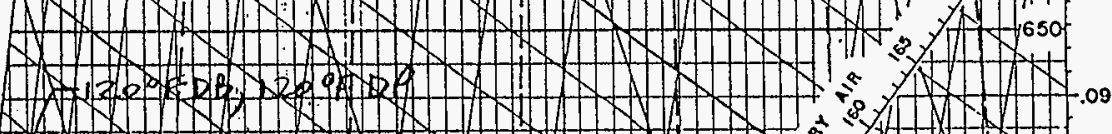

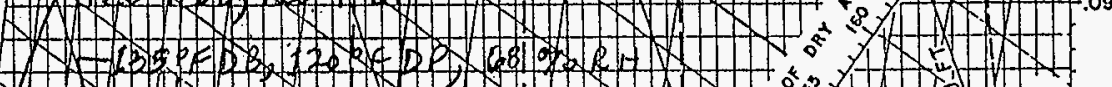

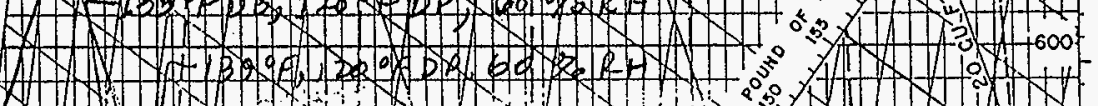

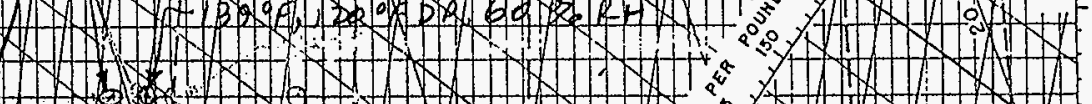

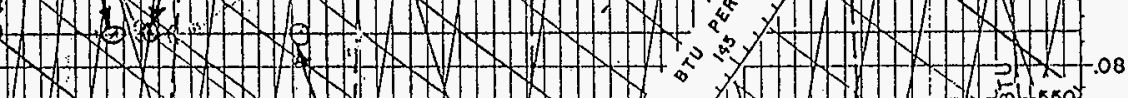

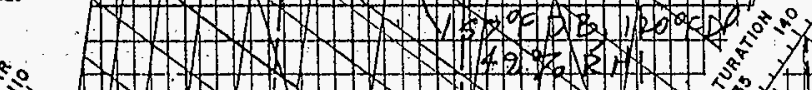

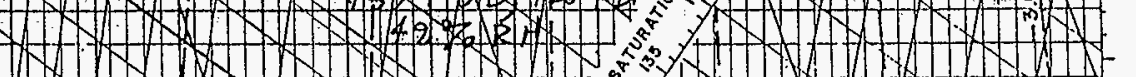

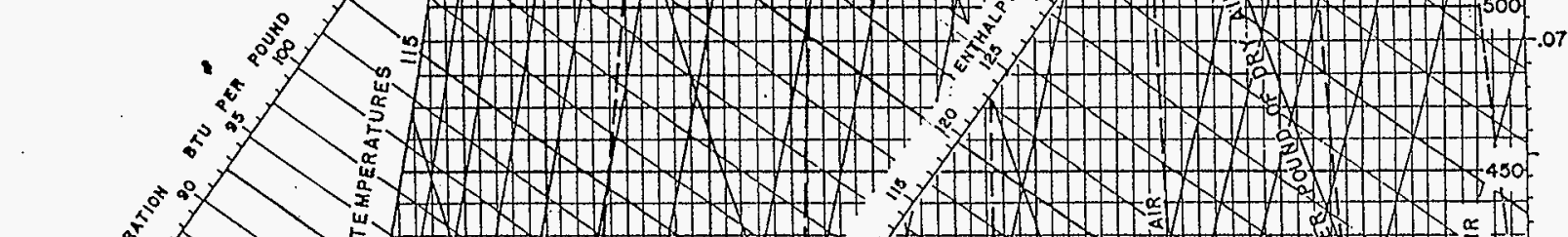

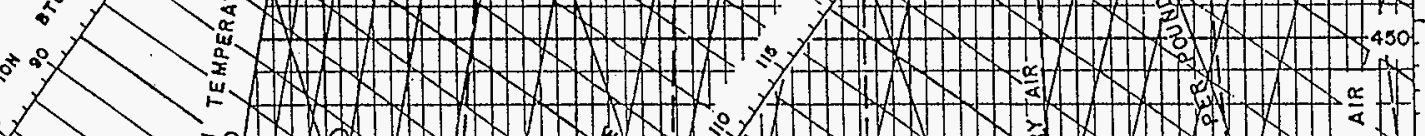

(1)

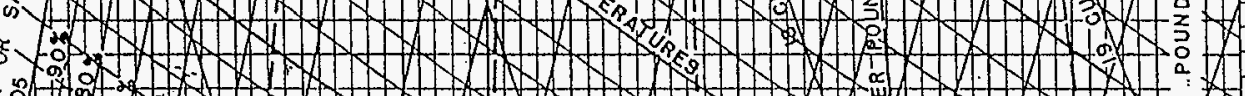
2. (1)

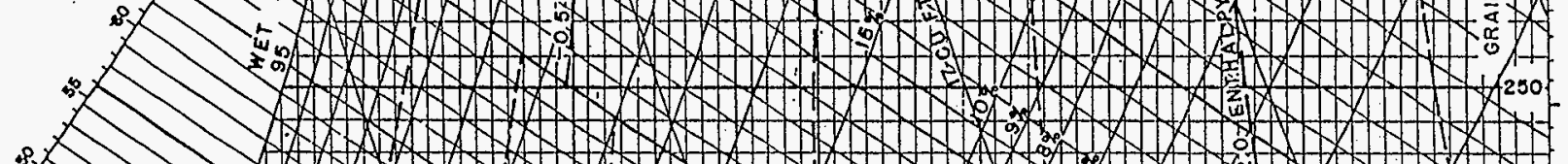

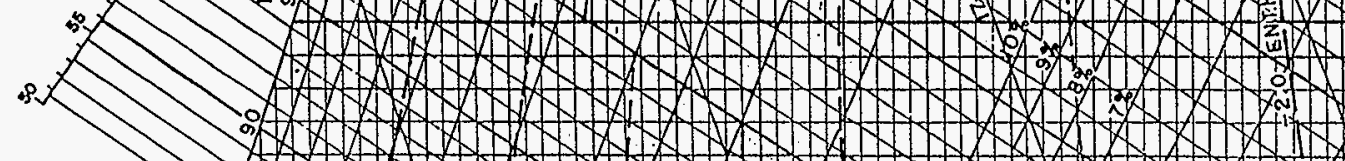

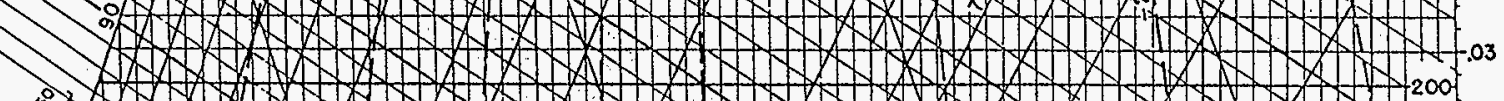

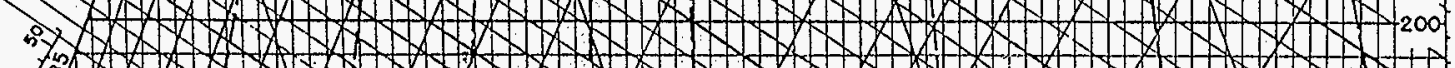

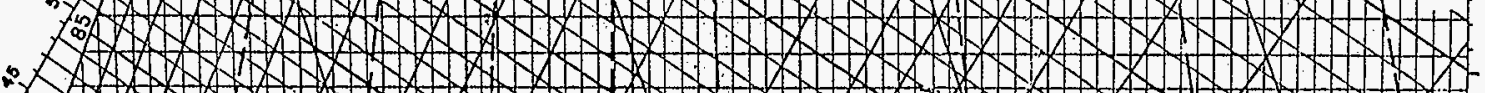

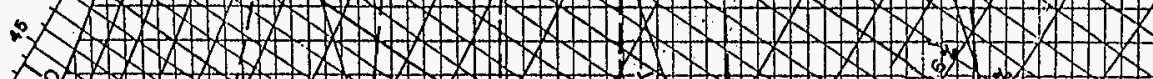

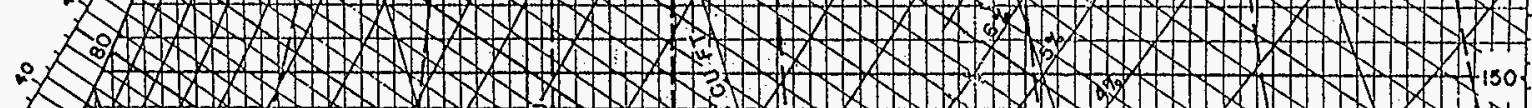

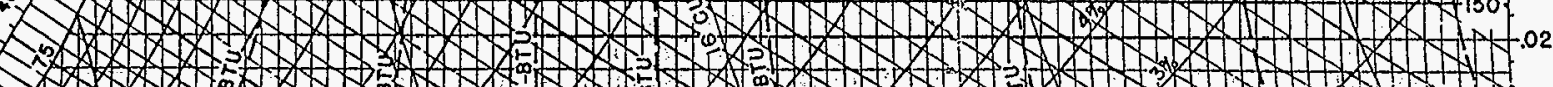

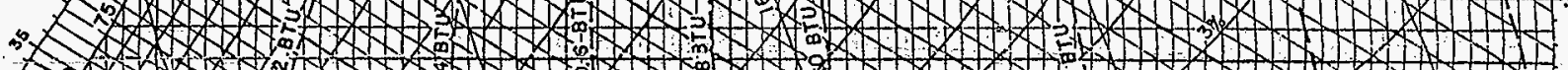

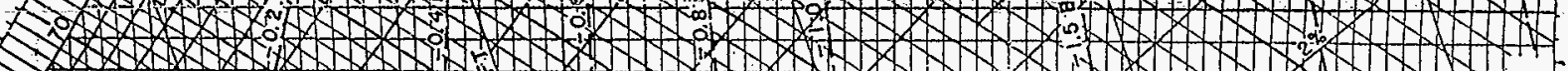

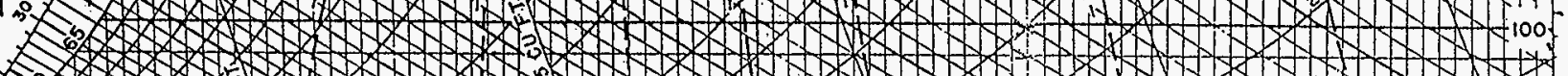

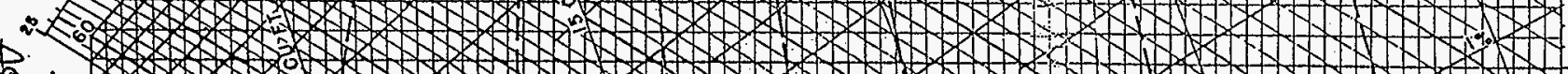
01.

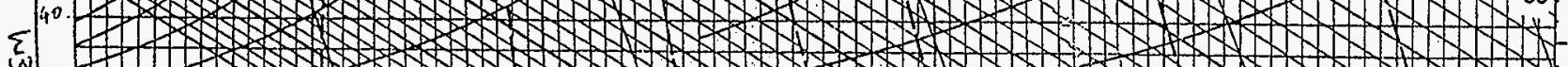
卢 so 잉

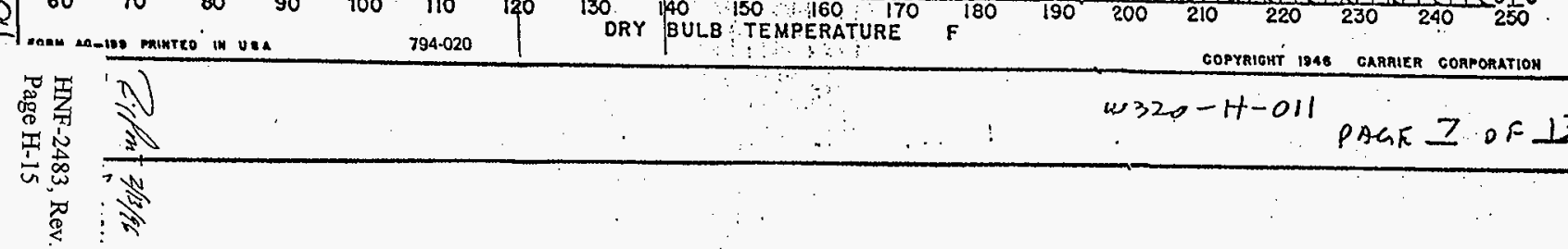


75

/

(y)

$1 / 1 / 4 / 1 / 1) / 0$

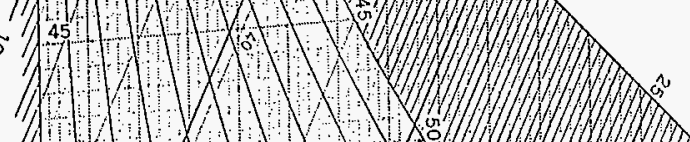

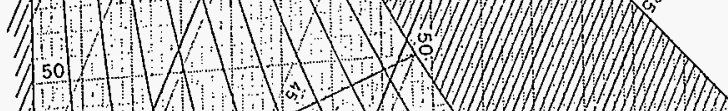

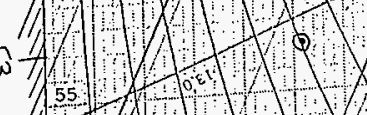

$1 / 5=(1 / 1)(1 / 6)$

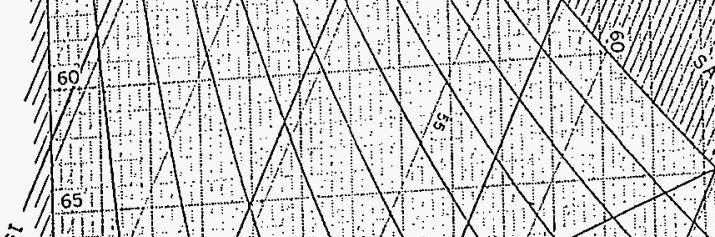

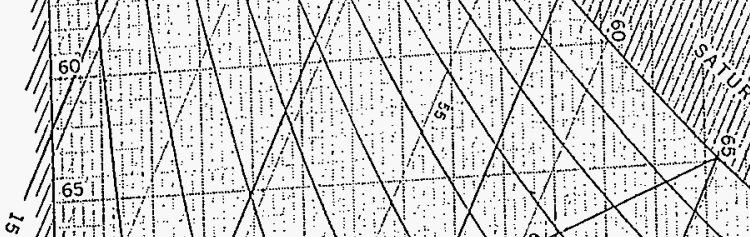

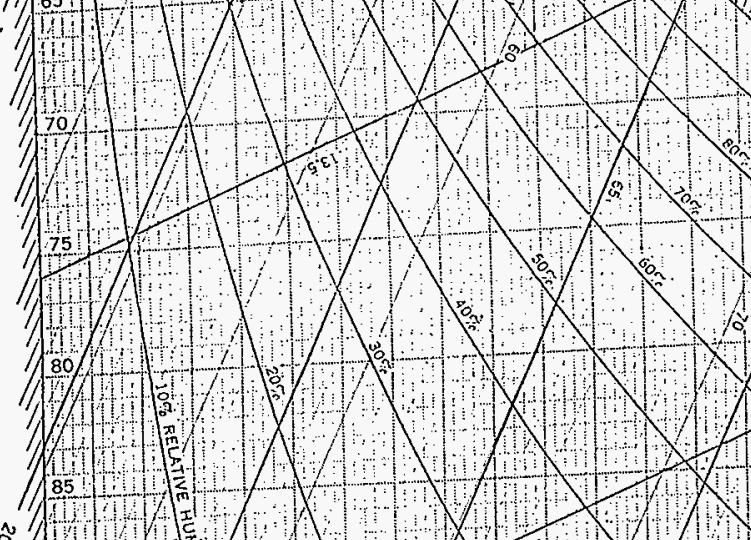

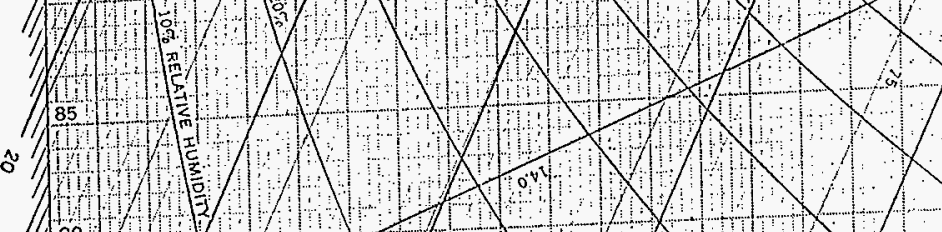

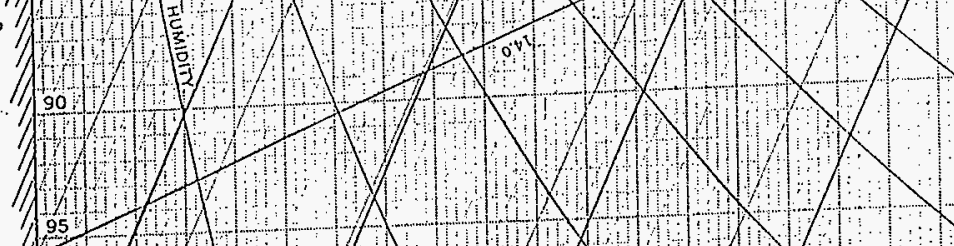

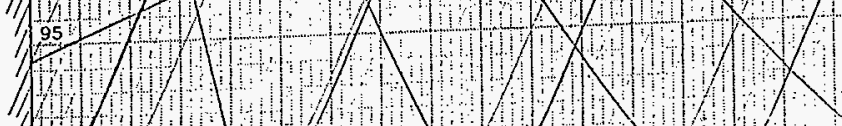

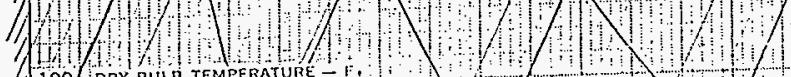

$\frac{7}{5}$

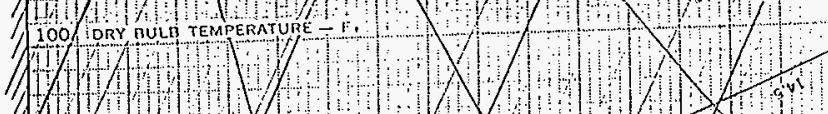

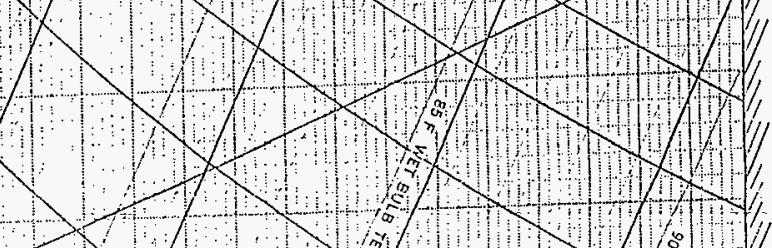




\section{DISTRIBUTION SHEET}

\begin{tabular}{|c|c|c|c|c|c|c|}
\hline \multirow{2}{*}{$\begin{array}{l}\text { To } \\
\text { Distribution }\end{array}$} & \multirow{2}{*}{\multicolumn{4}{|c|}{$\begin{array}{l}\text { From } \\
\text { JW Bailey }\end{array}$}} & \multicolumn{2}{|c|}{ Page 1 of 1} \\
\hline & & & & & \multicolumn{2}{|c|}{ Date 25 July 1998} \\
\hline \multirow{2}{*}{\multicolumn{5}{|c|}{ Project Title Work Order }} & \multicolumn{2}{|c|}{ EDT No. 622241} \\
\hline & & & & & \multicolumn{2}{|l|}{ ECN No. $n / a$} \\
\hline Name & $\therefore$ & MSIN & $\begin{array}{c}\text { Texî } \\
\text { With All } \\
\text { Attach. }\end{array}$ & Text Only & $\begin{array}{l}\text { Attach./ } \\
\text { Appendix } \\
\text { Only }\end{array}$ & $\begin{array}{c}\text { EDT/ECN } \\
\text { Only }\end{array}$ \\
\hline $\begin{array}{l}\text { JW Bailey } \\
\text { W-320 Project Files }\end{array}$ & & \multicolumn{5}{|l|}{$\begin{array}{l}\text { S2-48 } \\
\text { R1-29 }\end{array}$} \\
\hline
\end{tabular}

